\title{
4. SITE 588: LORD HOWE RISE, $26^{\circ} \mathrm{S}^{1}$
}

\author{
Shipboard Scientific Party ${ }^{2}$
}

\section{HOLE 588}

Date occupied: 6 December 1982

Date departed: 8 December 1982

Time on hole: $30 \mathrm{hr}$.

Position: $26^{\circ} 06.7^{\prime} \mathrm{S} ; 161^{\circ} 13.6^{\prime} \mathrm{E}$

Water depth (sea level; corrected m, echo-sounding): 1533

Water depth (rig floor; corrected m, echo-sounding): 1543

Bottom felt (m, drill pipe): 1548

Penetration (m): 236.00

Number of cores: 26

Total length of cored section $(\mathrm{m}): 236.00$

Total core recovered $(\mathrm{m}): 220.76$

Core recovery $(\%): 93.5$

Oldest sediment cored:

Depth sub-bottom (m): 236.00

Nature: Foraminifer-nannofossil ooze

Age: middle Miocene

Measured velocity $(\mathrm{km} / \mathrm{s}): 1.617 \mathrm{~km} / \mathrm{s}$ at $233 \mathrm{~m}$

Basement: Not reached

\section{HOLE 588A}

Date occupied: 8 December 1982

Date departed: 8 December 1982

Time on hole: $20 \mathrm{hr}$.

Position: $26^{\circ} 06.7^{\prime} \mathrm{S} ; 161^{\circ} 13.6^{\prime} \mathrm{E}$

1 Kennett, J. P., von der Borch, C. C., et al., Init. Repts. DSDP, 90: Washington (U.S.
Govt. Printing Office). Govt, Printing Office)

2 James P. Kennett (Co-Chief Scientist), Graduate School of Oceanography, University of Rhode Island, Narragansett, RI 02882; Christopher C. von der Borch (Co-Chief Scientist), School of Earth Sciences, Flinders University of South Australia, Bedford Park, South Australia 5042; Paul A. Baker, Department of Geology, Duke University, Durham, NC 27708; Charles E. Barton, Graduate School of Oceanography, University of Rhode Island, Narragansett, RI 02882 (present address: Bureau of Mineral Resources, Geology, and Geophysics, P.O. Box 378, Canberra, A.C.T., Australia); Anne Boersma, Microclimates, Inc., 404 RR1 Stony Point, NY 10980; Jean-Pierre Caulet, Laboratoire de Géologie, Muséum National d'Histoire Naturelle, 43 Rue Buffon, 75005, Paris, France; Walter C. Dudley, Jr., Natural Sciences Division, College of Arts and Sciences, University of Hawaii at Hilo, Hilo, Hawaii 96720; James V. Gardner, Pacific-Aretic Branch of Marine Geology, U.S. Geological Survey, 345 Middlefield Rd., Menlo Park, CA 94025; D. Graham Jenkins, Department of Earth Sciences, Open University, Walton Hall, Milton Keynes, MK7 6AA, Buckinghamshire, United Kingdom; William H. Lohman, Marathon Oil Co., Denver Research Center, P.O. Box 269, Littleton, CO 80160; Erlend Martini, Geologisch-Paläontologisches Institut, Johann-Wolfgang-Goethe Universităt, Senckenberg-Anlage 32-34, D-6000 Frankfurt am Main, Federal Republic of Germany; Russell B. Merrill, Deep Sea Drilling Project A031, Scripps Institution of Oceanography, La Jolla, CA 92093 (present address: Ocean Drilling Project, Texas A\&M University, College Station, TX 77843-3469); Roger Morin, Department of Earth and Planetary Sciences, Massachusetts Institute of Technology, Cambridge, MA 02139 (present address: US, Geological Survey, Def partment of Earth Sciences, University of Waikato, Private Bag, Hamilton, New Zealand Christian Robert, Laboratoire de Géologie Marine, Centre Universitaire de Luminy, Case 901 13288 Marseille Cedex 09, France; M. S. Srinivasan, Department of Geology, Banaras Hindu University, Varanasi 221005 , India; Rüdiger Stein, Geologisch-Paläontologisches Institut, Universität Kiel, 2300 Kiel, Federal Republic of Germany (present address: Institute of Petroleum and Organic Geochemistry (ICH-5), Kernforschungslage Jülich GmbH, P.O. Box 1913, 5170 Jülich, Federal Republic of Germany); Akira Takeuchi, Department of Earth Sciences, Faculty of Science, Toyama University, Gohuku 3190, Toyama 930, Japan.
Water depth (sea level; corrected m, echo-sounding): 1533

Water depth (rig floor; corrected m, echo-sounding): 1543

Bottom felt (m, drill pipe): 1548

Penetration (m): 344.4

Number of cores: 18

Total length of cored section $(\mathrm{m}): 108.40$

Total core recovered $(\mathrm{m}): 75.30$

Core recovery $(\%): 69.4$

Oldest sediment cored:

Depth sub-bottom (m): 344.4

Nature: Foraminifer-nannofossil ooze

Age: early Miocene

Basement: Not reached

\section{HOLE 588B}

Date occupied: 8 December 1982

Date departed: 10 December 1982

Time on hole: $31 \mathrm{hr}$.

Position: $26^{\circ} 06.7^{\prime} \mathrm{S} ; 161^{\circ} 13.6^{\prime} \mathrm{E}$

Water depth (sea level; corrected m, echo-sounding): 1533

Water depth (rig floor; corrected m, echo-sounding): 1543

Bottom felt (m, drill pipe): 1548

Penetration (m): 277.4

Number of cores: 31

Total length of cored section (m): 277.40

Total core recovered $(\mathrm{m}): 255.87$

Core recovery $(\%): 93$

Oldest sediment cored:

Depth sub-bottom (m): 277.4

Nature: Foraminifer-nannofossil ooze

Age: middle Miocene

Basement: Not reached

\section{HOLE 588C}

Date occupied: 10 December 1982

Date departed: 11 December 1982

Time on hole: $12 \mathrm{hr}$.

Position: $26^{\circ} 06.7^{\prime} \mathrm{S} ; 161^{\circ} 13.6^{\prime} \mathrm{E}$

Water depth (sea level; corrected m, echo-sounding): 1533

Water depth (rig floor; corrected m, echo-sounding): 1543

Bottom felt (m, drill pipe): 1548

Penetration (m): 488.1

Number of cores: 19

Total length of cored section (m): 182.40 


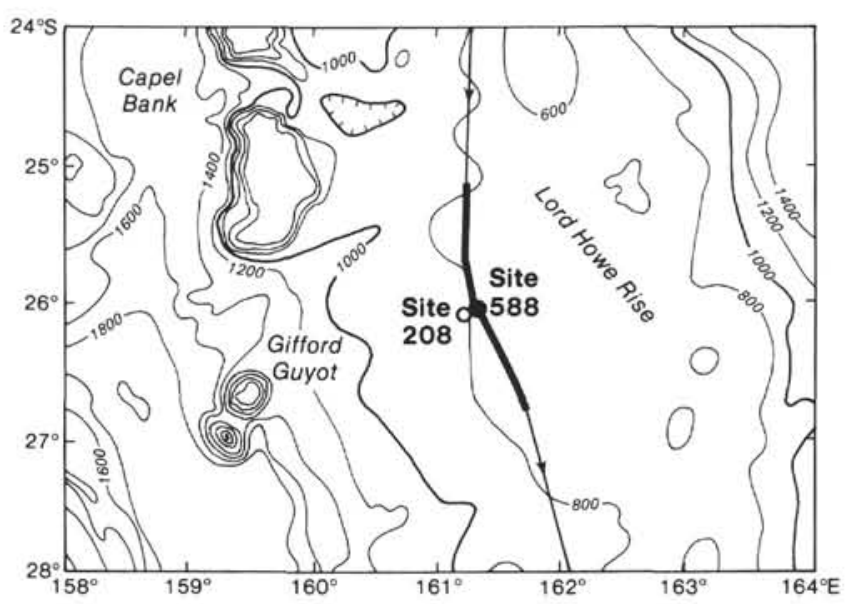

Figure 1. Regional bathymetry (fathoms) around Site 588, after Mammerickx, et al., 1974. Glomar Challenger Leg 90 track shown; heavy portion locates water gun seismic profile illustrated in Figure 2.

Total core recovered $(m): 135.61$

Core recovery $(\%): 74.3$

Oldest sediment cored:

Depth sub-bottom (m): 488.1

Nature: Siliceous foraminifer-bearing nannofossil chalk and foraminifer-bearing chert

Age: middle Miocene

Basement: Not reached

Principal results: Site 588 consists of four holes: Hole 588, which was cored continuously with the HPC from 0 to $236.0 \mathrm{~m}$ sub-bottom; Hole 588A, cored continuously with the HPC from 236.0 to $344.4 \mathrm{~m}$; Hole $588 \mathrm{~B}$, cored continuously with the HPC from 0 to $277.4 \mathrm{~m}$; and Hole $588 \mathrm{C}$, cored continuously with the rotary drill from 305.7 to $488.1 \mathrm{~m} \mathrm{BSF}$.

Site 588 is located at DSDP Site 208, in the warm subtropical water mass at $26^{\circ} \mathrm{S}$.

The HPC sequence through carbonate sediments is a record penetration of $315 \mathrm{~m}$, extending from the Quaternary to sediments of late early Miocene age (17 m.y.; Zone NN3 and Globorotalia miozea Zone). The overlapping hydraulic piston cores effectively provide $100 \%$ recovery of this sequence. Core quality is particularly good in the Miocene, much less so in the Pliocene, and especially poor in the Quaternary, which is soupy. The carbonate fossil sequence is exquisite through the Neogene, but less so in Oligocene sediments. Foraminiferal and calcareous nannofossil zonal sequences are complete, suggesting that there are no hiatuses above the upper Oligocene (NP24). A paleomagnetic polarity stratigraphy has been identified down to the upper part of the Gilbert Chron (about 3.5 m.y.).

Two sedimentary units are distinguished, the upper one divided into three subunits. Subunit IA is a brownish, foraminifer-rich nannofossil ooze in an oxidized and winnowed environment. Subunit IB, comprising most of the sediment column, is a foraminifer-bearing nannofossil ooze. Subunit IC is chalk. There are many thin volcanic ash layers throughout the Miocene sequence; they occur as singlets, doublets, or triplets and exhibit quasi-regular perodicites in some intervals. Most are completely undisturbed by bioturbation, which is unusually limited in this site. Unit II is a light greenish gray, siliceous foraminifer-bearing nannofossil chalk and associated chert of Eocene age.

Iron sulfides are persistent throughout the section and have a close association with volcanic ash layers. The site terminated in middle Eocene silica-rich chalks and cherts.

Textbook examples of microfaults and slickensides occur in three upper lower Miocene cores in a zone where ooze grades downward into chalks. Surfaces are occasionally mineralized by iron sulfide and possibly rhodochrosite.

The uncorrected rate of sedimentation is as follows: early Oligocene-early Miocene, $20.6 \mathrm{~m} / \mathrm{m}$.y.; early Miocene, 14.4 ; middle Miocene-early Pliocene, 17.4, lower Pliocene, 29.5; Quaternary, 12.2.

\section{BACKGROUND AND OBJECTIVES}

Site 588 (Fig. 1) was drilled at the same location as Site 208 on the northern part of Lord Howe Rise $\left(26^{\circ} 06^{\prime} \mathrm{S} ; 161^{\circ} 13^{\prime} \mathrm{E}\right)$ to obtain a high-quality, continuously cored sequence through the upper Paleogene and Neogene. The chosen site overlies a relatively thick sequence of acoustically transparent sediments (Figs. 2 and 3). Previous investigations have demonstrated that the planktonic foraminiferal assemblages at this latitude are made up of both tropical and temperate elements. Site 588 is now located in the warm subtropical water mass which lies between the true tropical water masses to the north and transitional water masses to the south. However, Site 588 experienced $5-10^{\circ}$ of northernly movement during the Neogene in association with movements of the Indian Plate (Sclater et al., in press). During the early Miocene, Site 588 was located at about $36^{\circ} \mathrm{S}$ in the present-day temperate area and within the zone of westerly winds. This northward movement from higher to lower latitudes must have had a major effect upon the ancient biogeography of the planktonic microfossil assemblages.

The section at Site 208 consists of about $430 \mathrm{~m}$ of Neogene and $58 \mathrm{~m}$ of upper Oligocene foraminiferalnannofossil oozes which make up Unit 1 as defined by the Leg 21 sedimentologists. Unit 1 is underlain by Unit 2, which is made up of Upper Cretaceous to lower middle Eocene siliceous-fossil-bearing nannofossil chalk. Unit 1 is separated from Unit 2 by the regional unconformity. The Site 208 sequence was continuously rotary cored from the Quaternary to the uppermost Miocene, then discontinuously cored to the base of the sequence. Rotary coring produced the usual mechanical disturbance of sediments; in addition, there are many long coring gaps in the section at Site 208.

The plan for Site 588 was to core two separate holes using the HPC in the upper part of the sequence, followed by continuous rotary coring in one hole to the level immediately below the regional unconformity separating the middle Eocene from the upper Oligocene at $488 \mathrm{~m}$ sub-bottom depth. Such a sequence would include all of Unit 1 as defined by the Leg 21 shipboard party. 


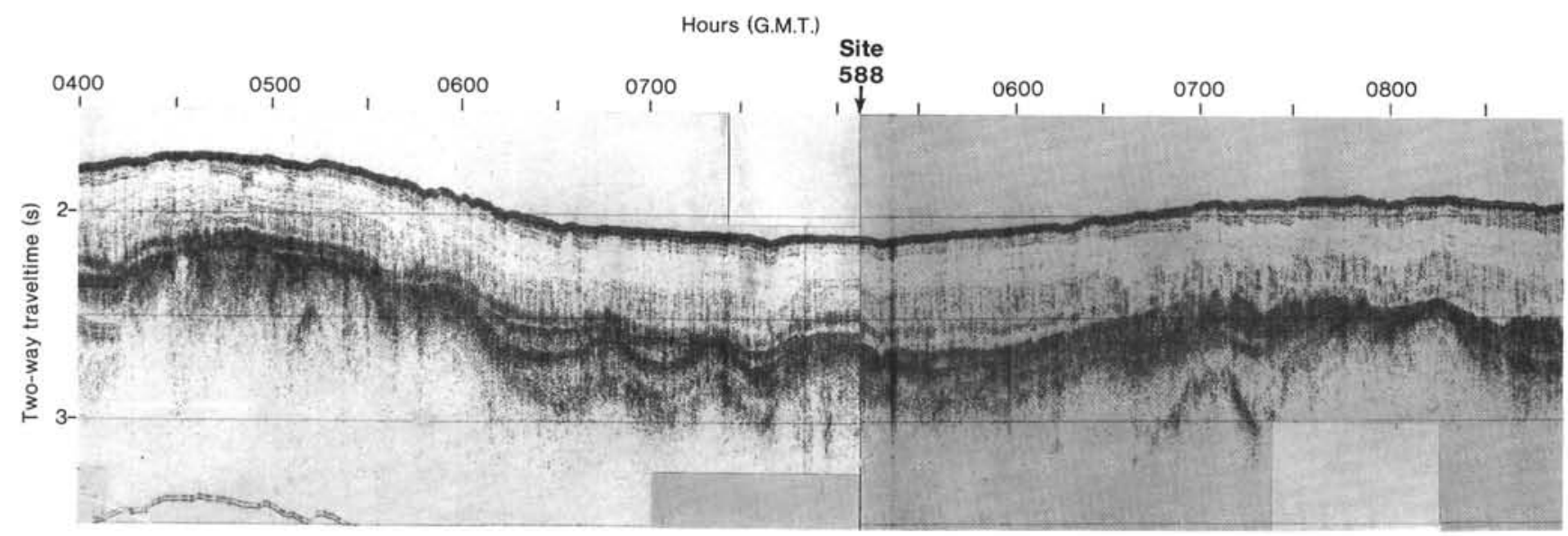

Figure 2. Water gun seismic profile (Glomar Challenger) near Site 588; bandpass filter 40-160 Hz.

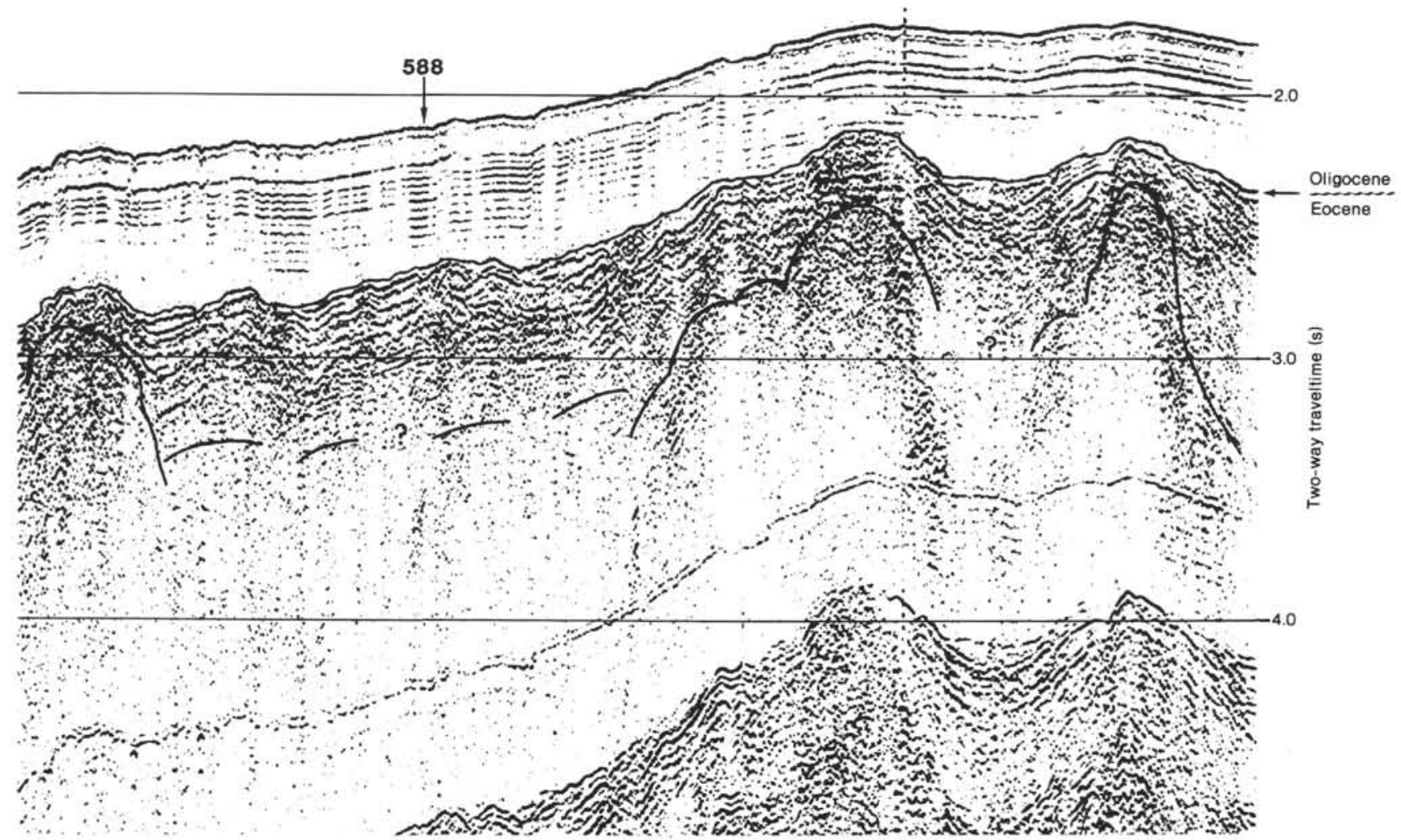

Figure 3. Location of Site 588 on Sonne multichannel seismic Profile SO-7-13. Courtesy of S. Hinz, Bundesanstalt für Geowissenschaften und Rohstoffe, FRG,

\section{OPERATIONS}

\section{Site 587 to Site 588}

Steaming between sites was routine, with ideal Tasman Sea summer weather and a quartering current. The ship covered the $295.6 \mathrm{n}$. mi. at an average speed of 10.5 knots. Routine underway geophysical data were collected between Sites 587 and 588, as described in the Operations Chapter for Site 587.

Site 588 was designed to reoccupy and utilize the HPC at Site 208, drilled during DSDP Leg 21. Several excellent seismic profiles were available for site selection (Conrad 12; Glomar Challenger, Leg 21; Sonne 50-7-12). The combination of simple Neogene stratigraphy, relatively flat topography, and uniformity of condition combined to make it unnecessary to carry out a presite survey. Glomar Challenger approached Site 588 from the north and dropped the beacon at 1921 hr., 6 Dec. 1982.

\section{Site 588 (SW-7): Northern Lord Howe Rise}

As at Site 587, a special bottom-hole assembly (BHA) was run, compatible with both piston coring and extended core barrel $(\mathrm{XCB})$ rotary coring. The operational plan for Site 588 called for taking duplicate unbroken pistoncored sequences through the Neogene, followed by rotary coring to the base of the Miocene. 
The first variable-length (VL) HPC shot was taken with the bit at $1544 \mathrm{~m}$; it recovered a $5.65-\mathrm{m}$ core which established the mud line at $1548 \mathrm{~m}$ (Table 1). Piston coring continued easily through calcareous ooze ranging from soupy to stiff for the first $216.8 \mathrm{~m}$. Recovery was consistently nearly $100 \%$, except for Core $588-8$, which came up empty. During this interval, 23 9.5-m VLHPC cores were taken. Full stroke on all was achieved using only two shear pins. Cores 588-24 and 588-25 were shot using three shear pins. Overpulls to free the tool after shootoff slowly increased to a maximum of $20,000 \mathrm{lbs}^{3}$

At Core 588-26, somewhat more than $100,000 \mathrm{lbs}$. overpull was applied to free the tool before the driller could stop the draw-works. The piston corer was recovered with its lower core-containing section missing, because the excessive tensile load associated with the overpull had caused a mechanical failure. The hole had to be terminated at this point.

\section{Hole 588A}

The bit was pulled to the mud line and Hole 588A was spudded at $0025 \mathrm{hr}$., 8 December, and washed to the termination point of Hole 588-236.0 BSF. One more 9.5-m VLHPC was deployed. When it experienced full stroke followed by excessive overpull, the bit was washed down over the entire $9.5 \mathrm{~m}$ until the tool was washed free.

It was then decided to employ the 5-m VLHPC as far as possible. Overpull was taken to a limit of $20-30,000$ lbs. on each core. If the corer could not be freed by pulling at that limit, the bit was washed over the extended section.

A new record depth for piston coring was reached in this manner- $315.6 \mathrm{~m} \mathrm{BSF}$ - and the oldest sediments ever successfully piston cored were recovered (upper lower Miocene). However, as the sediments stiffened, it became impossible to wash the bit over the protruding inner barrel without gouging the extended tool. Therefore, VLHPC work was terminated at Core 588A-15. Surprisingly, full stroking continued throughout the piston-cored sequence, despite the record total depth of penetration.

The XCB was then deployed for Cores $588 \mathrm{~A}-16$ to -18 . Poor recovery coupled with other symptoms indicated that the $\mathrm{XCB}$ was not functioning correctly, and it was decided to terminate Hole 588A and perform the repeat piston core sequence, using the time to modify the $\mathrm{XCB}$ system.

\section{Hole 588B}

Once again the bit was pulled to the mud line to spud a new hole. The vessel was offset $100 \mathrm{ft}$. to the north to assure a clean seafloor for a mud line core and Hole 588B was spudded at $2210 \mathrm{hr}$., 8 December. A good mud line core was shot from $1546 \mathrm{~m}$ to be certain that the coring sequence was staggered with respect to Holes 588 and $588 \mathrm{~A}$.

Piston coring proceeded smoothly again through calcareous ooze with scattered ash layers. Again full stroke of the $9.5 \mathrm{~m}$ VLHPC was routinely achieved with two

${ }^{3}$ The overpull is a measure of the force required to overcome the adhesion and suction which the sediment exerts on the extended section of the piston corer when it is implanted.
Table 1. Coring summary, Site 588.

\begin{tabular}{|c|c|c|c|c|c|c|c|}
\hline \multirow{2}{*}{$\begin{array}{l}\text { Core } \\
\text { No. }\end{array}$} & \multirow{2}{*}{$\begin{array}{l}\text { Date } \\
\text { (Dec. } \\
\text { 1982) }\end{array}$} & \multirow[b]{2}{*}{ Time } & $\begin{array}{l}\text { Depth from } \\
\text { drill floor } \\
\text { (m) }\end{array}$ & \multirow{2}{*}{$\begin{array}{l}\text { Depth below } \\
\text { seafloor } \\
\text { (m) } \\
\text { Top Bottom }\end{array}$} & \multirow{2}{*}{$\begin{array}{l}\text { Length } \\
\text { cored } \\
(\mathrm{m})\end{array}$} & \multirow{2}{*}{$\begin{array}{l}\text { Length } \\
\text { recovered } \\
\text { (m) }\end{array}$} & \multirow{2}{*}{$\begin{array}{l}\text { Percentage } \\
\text { recovered }\end{array}$} \\
\hline & & & Top Bottom & & & & \\
\hline \multicolumn{8}{|c|}{ Hole 588} \\
\hline 1 & 7 & 0200 & $1548.0-1553.6$ & $0.0-5.6$ & 5.6 & 5.65 & 100 \\
\hline 2 & 7 & 0250 & $1553.6-1563.2$ & $5.6-15.2$ & 9.6 & 9.64 & 100 \\
\hline 3 & 7 & 0340 & $1563.2-1572.8$ & $15.2-24.8$ & 9.6 & 9.18 & 95.6 \\
\hline 4 & 7 & 0420 & $1572.8-1582.4$ & $24.8-34.4$ & 9.6 & 9.43 & 98.2 \\
\hline 5 & 7 & 0510 & $1482.4-1592.0$ & $34,4-44.0$ & 9.6 & 9.11 & 94.9 \\
\hline 6 & 7 & 0600 & $1592.0-1601.6$ & $44.0-53.6$ & 9.6 & 9.38 & 97.7 \\
\hline 7 & 7 & 0650 & $1601.6-1611.2$ & $53.6-63.2$ & 9.6 & 9.05 & 94.2 \\
\hline 8 & 7 & 0730 & $1611.2-1620.8$ & $63.2-72.8$ & 9.6 & 0.0 & 0.0 \\
\hline 9 & 7 & 0820 & $1620.8-1630.4$ & $72.8-82.4$ & 9.6 & 9.48 & 98.7 \\
\hline 10 & 7 & 0910 & $1630.4-1640.0$ & $82.4-92.0$ & 9.6 & 8.78 & 91.4 \\
\hline 11 & 7 & 1000 & $1640.0-1649.6$ & $92.0-101.6$ & 9.6 & 9.49 & 98.8 \\
\hline 12 & 7 & 1050 & $1649.6-1659.2$ & $101.6-111.2$ & 9.6 & 9.54 & 99.4 \\
\hline 13 & 7 & 1130 & $1659.2-1668.8$ & $111.2-120.8$ & 9.6 & 9.49 & 98.5 \\
\hline 14 & 7 & 1220 & $1668.8-1678.4$ & $120.8-130.4$ & 9.6 & 9.71 & 100 \\
\hline 15 & 7 & 1320 & $1678.4-1688.0$ & $130.4-140.0$ & 9.6 & 9.44 & 98 \\
\hline 16 & 7 & 1415 & $1688.0-1697.6$ & $140.0-149.6$ & 9.6 & 5.8 & 61 \\
\hline 17 & 7 & 1510 & $1697.6-1707.2$ & $149.6-159.2$ & 9.6 & 9.63 & 100 \\
\hline 18 & 7 & 1555 & $1707.2-1716.8$ & $159.2-168.8$ & 9.6 & 9.38 & 98 \\
\hline 19 & 7 & 1630 & $1716.8-1726.4$ & $168.8-178.4$ & 9.6 & 9.64 & $100+$ \\
\hline 20 & 7 & 1735 & $1726.4-1736.0$ & $178.4-188.0$ & 9.6 & 9.77 & $100+$ \\
\hline 21 & 7 & 1820 & $1736.0-1745.6$ & $188.0-197.6$ & 9.6 & 9.78 & $100+$ \\
\hline 22 & 7 & 1930 & $1745.6-1755.2$ & $197.6-207.2$ & 9.6 & 9.81 & $100+$ \\
\hline 23 & 7 & 2015 & $1755.2-1764.8$ & $207.2-216.8$ & 9.6 & 9.82 & $100+$ \\
\hline 24 & 7 & 2100 & $1764.8-1774.4$ & $216.8-226.4$ & 9.6 & 9.66 & $100+$ \\
\hline \multirow[t]{2}{*}{25} & 7 & 2140 & $1774.4-1785.0$ & $226.4-236.0$ & 9.6 & 10.04 & $100+$ \\
\hline & & & & & 236.00 & 220.76 & 93.5 \\
\hline
\end{tabular}

Hole 588A

$\begin{array}{rlll}1 & 8 & 0300 & 1784.0-1793.6 \\ 2 & 8 & 0400 & 1793.6-1798.6 \\ 3 & 8 & 0500 & 1798.6-1803.6 \\ 4 & 8 & 0550 & 1803.6-1808.6 \\ 5 & 8 & 0645 & 1808.6-1813.6 \\ 6 & 8 & 0740 & 1813.6-1818.6 \\ 7 & 8 & 0830 & 1818.6-1823.6 \\ 8 & 8 & 0920 & 1823.6-1828.6 \\ 9 & 8 & 1010 & 1828.6-1833.6 \\ 10 & 8 & 1115 & 1833.6-1838.6 \\ 11 & 8 & 1210 & 1838.6-1843.6 \\ 12 & 8 & 1308 & 1843.6-1848.6 \\ 13 & 8 & 1415 & 1848.6-1853.6 \\ 14 & 8 & 1500 & 1853.6-1858.6 \\ 15 & 8 & 1545 & 1858.6-1863.6 \\ 16 & 8 & 1720 & 1863.6-1873.2 \\ 17 & 8 & 1850 & 1873.2-1882.8 \\ 18 & 8 & 1930 & 1882.8-1892.4\end{array}$

\begin{tabular}{cccc}
$236.0-245.6$ & 9.6 & 9.76 & $100+$ \\
$245.6-250.6$ & 5.0 & 5.16 & $100+$ \\
$250.6-255.6$ & 5.0 & 5.23 & $100+$ \\
$255.6-260.6$ & 5.0 & 4.91 & 98.2 \\
$260.6-265.6$ & 5.0 & 4.39 & $100+$ \\
$265.6-270.6$ & 5.0 & 5.18 & $100+$ \\
$270.6-275.6$ & 5.0 & 5.19 & $100+$ \\
$275.6-280.6$ & 5.0 & 5.27 & $100+$ \\
$280.6-285.6$ & 5.0 & 4.96 & 99.2 \\
$285.6-290.6$ & 5.0 & 5.20 & $100+$ \\
$290.6-295.6$ & 5.0 & 4.22 & 84.4 \\
$295.6-300.6$ & 5.0 & 5.19 & $100+$ \\
$300.6-305.6$ & 5.0 & 5.21 & $100+$ \\
$305.6-310.6$ & 5.0 & 3.78 & 76 \\
$310.6-315.6$ & 5.0 & 5.22 & $100+$ \\
$315.6-325.2$ & 9.6 & 0.16 & 2 \\
$325.2-334.8$ & 9.6 & 2.35 & 24 \\
$334.8-344.4$ & 9.6 & 2.89 & 30 \\
\cline { 2 - 4 } & 108.40 & 84.27 & 77.7
\end{tabular}

Hole 588B

1
2
3
4
5
6
7
8
9
10
11
12
13
14
15
16
17
18
19
20
21
22
23
24
25
26
27
28
29
30
31

2250
2350
0025
0120
0200
0305
0345
0430
0520
0600
0648
0740
0830
0920
1000
1053
1310
1400
1450
1545
1630
1725
1815
1925
2015
2104
2205
2300
0145
0250
0415

$1547.8-1555.6$
$1555.6-1565.2$
$1565.2-1574.8$
$1574.8-1584.4$
$1584.4-1594.0$
$1594.0-1603.6$
$1603.6-1613.2$
$1613.2-1622.8$
$1622.8-1632.4$
$1632.4-1642.0$
$1642.0-1651.6$
$1651.6-1661.2$
$1661.2-1670.8$
$1670.8-1680.4$
$1680.4-1690.0$
$1690.0-1699.6$
$1699.6-1709.2$
$1709.2-1718.8$
$1718.8-1728.4$
$1728.4-1738.0$
$1738.6-1747.6$
$1747.6-1757.2$
$1757.2-1766.8$
$1766.8-1776.4$
$1776.4-1781.4$
$1781.4-1786.4$
$1786.4-179.4$
$1791.4-1796.4$
$1796.4-180.0$
$1806.0-1815.6$
$1815.6-1825.2$

$0.0-7.8$
$7.8-17.4$
$17.4-27.0$
$27.0-36.6$
$36.6-46.2$
$46.2-55.8$
$55.8-65.4$
$65.4-75.0$
$75.0-84.6$
$84.6-94.2$
$94.2-103.8$
$103.8-113.4$
$113.4-123.0$
$123.0-132.6$
$132.6-142.2$
$142.2-151.8$
$151.8-161.4$
$161.4-171.0$
$171.0-180.6$
$180.6-190.2$
$190.2-199.8$
$199.8-209.4$
$209.4-219.0$
$219.0-228.6$
$228.6-233.6$
$233.6-238.6$
$238.6-243.6$
$243.6-248.6$
$248.6-258.2$
$258.2-267.8$
$267.8-277.4$

\begin{tabular}{ccc}
7.8 & 7.79 & 100 \\
9.6 & 9.63 & $100+$ \\
9.6 & 9.57 & 99.6 \\
9.6 & 8.91 & 92.8 \\
9.6 & 9.70 & $100+$ \\
9.6 & 7.92 & 82.5 \\
9.6 & 9.17 & 95.5 \\
9.6 & 9.58 & 100 \\
9.6 & 9.58 & 99.7 \\
9.6 & 4.04 & 42.0 \\
9.6 & 9.49 & 98.8 \\
9.6 & 9.83 & $100+$ \\
9.6 & 9.42 & 98.1 \\
9.6 & 9.69 & $100+$ \\
9.6 & 9.30 & 96.8 \\
9.6 & 9.14 & 95.2 \\
9.6 & 9.68 & $100+$ \\
9.6 & 9.45 & 98 \\
9.6 & 9.60 & 100 \\
9.6 & 9.80 & $100+$ \\
9.6 & 9.47 & 99 \\
9.6 & 9.30 & 97 \\
9.6 & 9.66 & $100+$ \\
9.6 & 8.91 & 93 \\
5.0 & 5.15 & $100+$ \\
5.0 & 5.27 & $100+$ \\
5.0 & 5.15 & $100+$ \\
5.0 & 5.20 & $100+$ \\
9.6 & 6.95 & 72.3 \\
9.6 & 3.79 & 39.4 \\
9.6 & 5.73 & 59.6 \\
\hline 277.40 & 255.87 & 93.0 \\
& &
\end{tabular}

Hole 588C

\begin{tabular}{llllllll}
1 & 10 & 1630 & $1853.5-1863.1$ & $305.7-315.3$ & 9.6 & 9.42 & 98 \\
2 & 10 & 1735 & $1863.1-1872.1$ & $315.3-324.9$ & 9.6 & 8.99 & 94 \\
3 & 10 & 1830 & $1872.7-1882.3$ & $324.9-334.5$ & 9.6 & 8.94 & 93 \\
\hline
\end{tabular}


Table 1. (Continued).

\begin{tabular}{|c|c|c|c|c|c|c|c|}
\hline \multirow{2}{*}{$\begin{array}{l}\text { Core } \\
\text { No. }\end{array}$} & \multirow{2}{*}{$\begin{array}{l}\text { Date } \\
\text { (Dec. } \\
\text { 1982) }\end{array}$} & \multirow[b]{2}{*}{ Time } & $\begin{array}{l}\text { Depth from } \\
\text { drill floor } \\
\text { (m) }\end{array}$ & \multirow{2}{*}{$\begin{array}{l}\text { Depth below } \\
\text { seafloor } \\
\text { (m) } \\
\text { Top Bottom }\end{array}$} & \multirow{2}{*}{$\begin{array}{l}\text { Length } \\
\text { cored } \\
\text { (m) }\end{array}$} & \multirow{2}{*}{$\begin{array}{l}\text { Length } \\
\text { recovered } \\
\text { (m) }\end{array}$} & \multirow{2}{*}{$\begin{array}{l}\text { Percentage } \\
\text { recovered }\end{array}$} \\
\hline & & & Top Bottom & & & & \\
\hline \multicolumn{8}{|c|}{ Hole $588 \mathrm{C}$ (Cont.) } \\
\hline 4 & 10 & 1925 & 1882.3-1891.9 & $334.5-344.1$ & 9.6 & 8.82 & 92 \\
\hline 5 & 10 & 2025 & 1891.9-1901.5 & $344.1-353.7$ & 9.6 & 9.02 & 94 \\
\hline 6 & 10 & 2130 & $1901.5-1911.1$ & $353.7-363.3$ & 9.6 & 9.63 & $100+$ \\
\hline 7 & 10 & 2210 & $1911.1-1920.7$ & $363.3-372.9$ & 9.6 & 5.88 & 61.2 \\
\hline 8 & 10 & 2325 & $1920.7-1930.3$ & $373.9-382.5$ & 9.6 & 9.43 & 98.2 \\
\hline 9 & 11 & 0002 & 1930.3-1939.9 & $382.5-392.1$ & 9.6 & 9.62 & $100+$ \\
\hline 10 & II & 0052 & 1939.9-1949.5 & $392.1-401.7$ & 9.6 & 7.42 & 80.6 \\
\hline 11 & 11 & 0245 & $1949.5-1959.1$ & $401.7-411.3$ & 9.6 & 4.44 & 46.2 \\
\hline 12 & 11 & 0355 & $1959.1-1968.7$ & $411.3-420.9$ & 9.6 & 8.13 & 84.6 \\
\hline 13 & 11 & 0455 & $1968.7-1978.3$ & $420.9-430.5$ & 9.6 & 8.88 & 92.5 \\
\hline 14 & 11 & 0550 & 1978.3-1987.9 & $430.5-440.1$ & 9.6 & 7.20 & 75.0 \\
\hline 15 & 11 & 0640 & 1987.9-1997.5 & $440.1-449.7$ & 9.6 & 6.40 & 66.6 \\
\hline 16 & II & 0743 & $1997.5-2007.1$ & $449.7-459.3$ & 9.6 & 5.32 & 55.4 \\
\hline 17 & 11 & 0835 & $2007.1-2016.7$ & $459.3-468.9$ & 9.6 & 5.60 & 58.3 \\
\hline 18 & 11 & 0950 & $2016.7-2026.3$ & $468.9-478.5$ & 9.6 & 0.62 & 6.4 \\
\hline \multirow[t]{2}{*}{19} & II & 1040 & 2026.3-2035.9 & $478.5-488.1$ & 9.6 & 0.85 & 8.85 \\
\hline & & & & & 182.40 & 134.61 & 73.8 \\
\hline
\end{tabular}

shear pins. The same scenario of increasing overpull requirements was experienced as in the previous hole, this time beginning about $30 \mathrm{~m}$ higher. Cores $588 \mathrm{~B}-25$ to 588B-28 were taken with the 5-m VLPHC. Piston coring was then terminated.

Again the XCB was deployed, now modified to allow proper venting. Cores were taken on all three deployments but they were not of good quality. Partial collapse and splitting of the plastic core liners occurred on all three attempts. The XCB obviously needed further work and the scientific objective of rotary coring to the Neogene/Paleogene unconformity had not yet been reached, so it was decided to trip the pipe in order to change the bit and BHA for conventional rotary coring.

\section{Hole 588C}

The pipe was tripped and a standard BHA with a long-tooth, tungsten carbide insert $\mathrm{F} 93 \mathrm{CK}$ bit was assembled and run back to the seafloor. Hole $588 \mathrm{C}$ was spudded at $1307 \mathrm{hr}$., 10 December. The bit was quickly washed to a depth of $305.7 \mathrm{~m}$ BSF to provide a slight overlap with the deepest penetration of the piston coring done earlier.

Routine rotary coring then followed, with good core recovery through foraminifer-bearing nannofossil chalk with green ash layers and abundant burrows. The only delay was a $45 \mathrm{~min}$. wait on weather while the vessel took a $400 \mathrm{ft}$. excursion under the influence of a brief but dramatic line squall bearing 50 m.p.h. winds. At $488.1 \mathrm{~m} \mathrm{BSF}$ the scientific objective was reached and the hole was terminated. The pipe was tripped and the vessel got under way for Site 589 at 1536 hr., 11 December.

\section{LITHOSTRATIGRAPHY}

Site 588 consists of four holes: Hole 588 was cored continuously with the HPC from 0 to 236.0 sub-bottom; Hole 588A was cored continuously with the HPC from 236.0 to $344.4 \mathrm{~m}$; Hole 588B was cored continuously with the HPC from 0 to $277.4 \mathrm{~m}$; and Hole 588C was cored continuously with the rotary drill from 305.7 to $488.1 \mathrm{~m}$ sub-bottom. The recovered sequence is di- vided into two lithostratigraphic units, based upon color and composition (Fig. 4; Table 2).

Subunit IA is a foraminifer-bearing nannofossil ooze to nannofossil-bearing foraminiferal ooze extending from the seafloor to 6.5 or $6.8 \mathrm{~m} \mathrm{BSF}$. It is distinguished by its color, which ranges from orange to brown, whereas that of the underlying Subunit IB is white to light gray. Within Subunit IA, a color gradation exists from grayish orange (10Y $7 / 4,10 \mathrm{Y} 7 / 3)$ and pale yellowish brown $(10 \mathrm{Y} 6 / 2)$ in the topmost meter of the sediment column to very pale orange $(10 \mathrm{Y} 8 / 2)$ in the remainder of the subunit.

There are several distinct beds within Subunit IA that differ in color, grain size, and composition. The beds are generally separated from each other by sharp contacts. The foraminifers vary in abundance from 5 to $75 \%$ and usually form about $25 \%$ of the sediment (estimated from smear slides; see Fig. 5). High abundance (75\%) was seen only in Sample 588B-1-4, 115-150 cm, which contains the coarsest sediment found at Site 588 . Calcareous nannofossils comprise the bulk ( 25 to $95 \%$ ) of the remaining sediment. Noncarbonate components in this subunit include traces of quartz, feldspar, heavy minerals, and sponge spicules.

The preliminary interpretation is that Subunit IA is an oxidized and winnowed facies. The sharp color contrast that separates Subunit IA from underlying Subunit IB represents a fundamental change in diagenetic environment as well as in sedimentological environment. Increased current caused winnowing and concentrated the foraminifers. As a result of the coarser grain size, oxidation of organic matter in these sediments was complete within $7 \mathrm{~m}$ of the seafloor.

Subunit IB comprises much of the sediment column at Site $588(6.5$ to about $250 \mathrm{~m})$. It is predominantly a foraminifer-bearing nannofossil ooze; rarely, it is a foraminifer-nannofossil ooze or a nannofossil ooze. It is distinguished from underlying Subunit IC by its softness: Subunit IC is a chalk. Subunit IC grades from soft ooze at its top to firm ooze at about 150 to $180 \mathrm{~m}$ (Holes 588 and $588 \mathrm{~B}$, respectively) to chalk at about 215 to $260 \mathrm{~m}$ (Holes 588 and 588B, respectively). Foraminifer abundances typically vary between 5 and $25 \%$ in both subunits. Siliceous microfossils are almost entirely absent. The only noncarbonate components that occur in greater than trace amounts are volcanic ash and iron sulfide minerals. The changing abundance of these components is responsible for the overall color changes within Subunits IB and IC. The volcanic ash imparts a green color to the normally white sediment, in shades from very light greenish gray to dark bluish green. The iron sulfide imparts a gray color to the sediment, in shades varying from very light gray to dark gray. Because these components are generally less than $10 \%$ in abundance, the light colors prevail.

Sedimentary structures in Subunits IB and IC include bedding and burrowing features. Some beautiful examples of Zoophycos and Chondrites burrows occur throughout this unit, as do a number of circular or ovoid (0.5$3.0 \mathrm{~cm}$ across) burrow sections and mottles. Some flaser- 


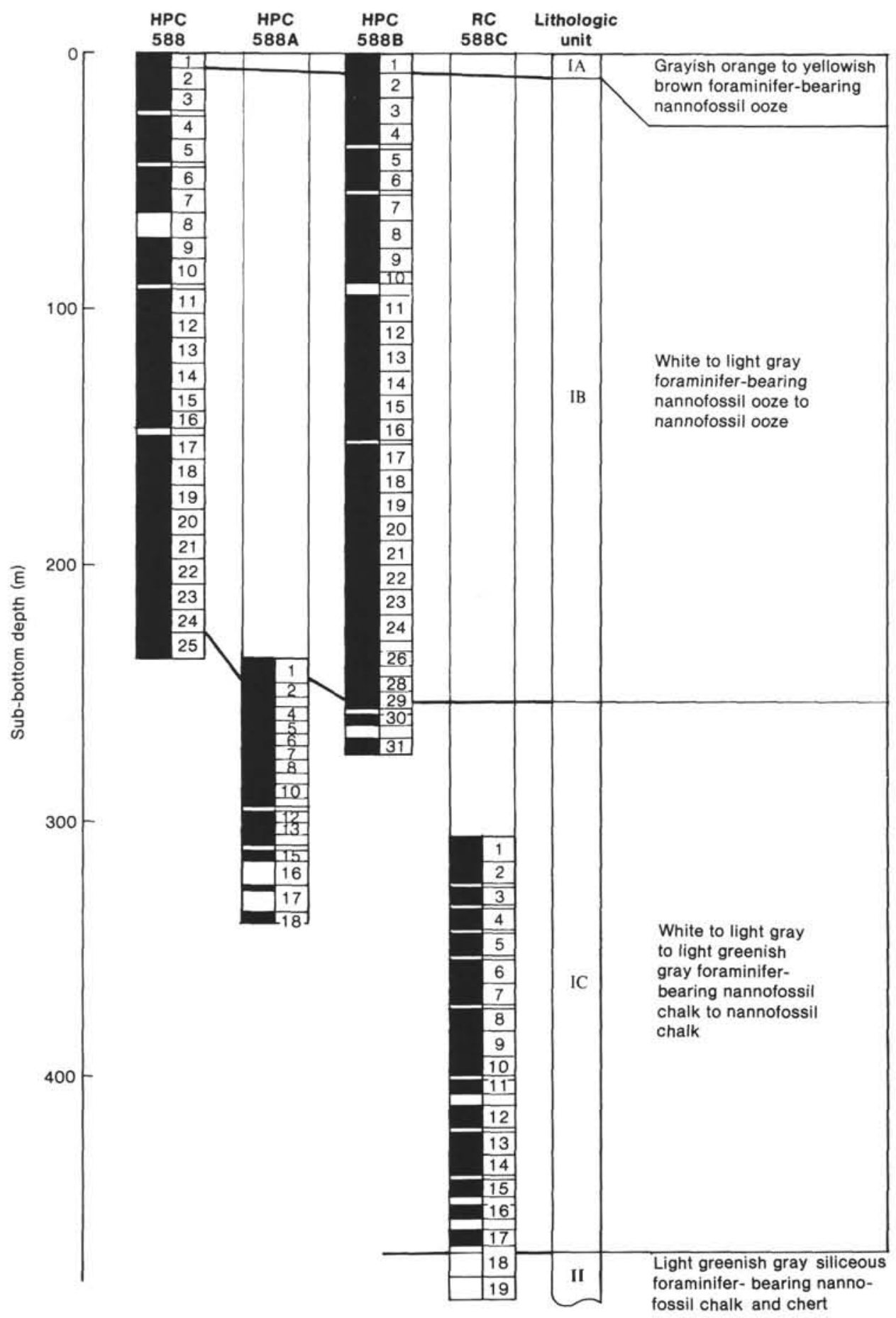

Figure 4. Lithostratigraphy of Site 588. Recovery in black. HPC = hydraulic piston cored, RC = rotary cored.

like bedding is apparent within Subunit IC (Sections 588C-5-3 and 588C-18-1).

Disseminated volcanic ash or glass is present throughout Subunits IB and IC. Glass occurs as ovoid bubbles and as angular shards in the uppermost parts of the unit (e.g., 588-4-1, $81 \mathrm{~cm}$ ). In addition, thin $(0.5-15 \mathrm{~mm}$ thick), light greenish gray laminae, possibly composed of altered volcanic ash, are common below about $160 \mathrm{~m}$ sub-bottom to the base of the unit. These layers almost exclusively occur in singlets, doublets, and triplets with- in about $2 \mathrm{~cm}$ of section. Furthermore, the layers occur throughout the section with quasi-regular frequency.

Iron sulfide minerals have been diagenetically formed throughout the unit as a result of mild degrees of microbial sulfate reduction. These minerals occur in blebs, pockets, and burrows. Small, solid tubes (1 to $2 \mathrm{~mm}$ in diameter, several $\mathrm{cm}$ long) of black iron sulfide fill many of the small burrows. One large $(3$ to $5 \mathrm{~cm}$ ) pyrite nodule in Section 588-17-2 containing well-formed pyrite crystals is a burrow fill. A close stratigraphic association oc- 
Table 2. Lithostratigraphy at Site 588.

\begin{tabular}{|c|c|c|c|c|}
\hline $\begin{array}{l}\text { Lithologic } \\
\text { units }\end{array}$ & Cores $^{\mathrm{a}}$ & $\begin{array}{l}\text { Sub-bottom } \\
\text { depth (m) }\end{array}$ & Description & Age \\
\hline IA & $\begin{array}{l}1-2 \\
1 \mathrm{~B}\end{array}$ & $\begin{array}{l}0.0-6.6 \\
0.0-6.8\end{array}$ & $\begin{array}{l}\text { Grayish orange to yellowish } \\
\text { brown (oxidized), } \\
\text { foraminifer-bearing } \\
\text { nannofossil ooze }\end{array}$ & Quaternary \\
\hline IB & $\begin{array}{c}2-24 \\
1 \mathrm{~A} \\
1 \mathrm{~B}-29 \mathrm{~B}\end{array}$ & $\begin{array}{r}6.6-226.4 \\
236.0-245.6 \\
6.8-253.0\end{array}$ & $\begin{array}{l}\text { White to light gray, fora- } \\
\text { minifer-bearing nanno- } \\
\text { fossil ooze to nannofos- } \\
\text { sil ooze }\end{array}$ & $\begin{array}{l}\text { Quaternary to } \\
\text { middle } \\
\text { Miocene }\end{array}$ \\
\hline IC & $\begin{array}{c}25 \\
2 \mathrm{~A}-18 \mathrm{~A} \\
29 \mathrm{~B}-31 \mathrm{~B} \\
1 \mathrm{C}-18 \mathrm{C}\end{array}$ & $\begin{array}{l}226.4-236.0 \\
245.6-344.4 \\
253.0-277.4 \\
305.7-469.0\end{array}$ & $\begin{array}{l}\text { White to light gray to light } \\
\text { greenish gray, foramini- } \\
\text { fer-bearing nannofossil } \\
\text { chalk to nannofossil } \\
\text { chalk }\end{array}$ & $\begin{array}{c}\text { middle Miocene } \\
\text { to late } \\
\text { Oligocene }\end{array}$ \\
\hline II & $18 \mathrm{C}-19 \mathrm{C}$ & $469.0-488.1$ & $\begin{array}{l}\text { Light greenish gray, siliceous } \\
\text { foraminifer-bearing } \\
\text { nannofossil chalk and } \\
\text { chert }\end{array}$ & middle Eocene \\
\hline
\end{tabular}

a Letters following core number refer to the hole from which core is taken.

curs between iron sulfide and light greenish gray ash(?) layers. In most instances, iron sulfide streaks occur below these layers (but not often above them). This association suggests that the ash(?) layers are a source of iron during diagenesis.

Hole $588 \mathrm{~A}$ was terminated at about $335 \mathrm{~m}$ (Core $588 \mathrm{~A}-18$ ) when the HPC ceased to penetrate, possibly because chert was present. A fist-sized nodule found in Section 588A-18-2 was the only occurrence of chert in Unit I. No chert was found during rotary drilling at an equivalent depth in Hole 588C.

One of the most controversial shipboard sedimentological problems encountered at Site 588 centers on the origin of the microfaults and slickensides observed in Cores $588 \mathrm{C}-3$ through $588 \mathrm{C}-5$. In this interval there are several faults with apparently normal dip-slip offsets of 5 to $10 \mathrm{~mm}$, usually occurring along highly angled surfaces (about $60^{\circ}$ ). The faces of these surfaces are often slickensided and occasionally mineralized by iron sulfide and possibly rhodochrosite. Two hypotheses for their origin prevail: either the features were produced naturally by tectonism, or the features were produced artificially by drilling. One argument favoring the tectonic origin of these features is the known Neogene tectonism in nearby areas. For example, the Leg 90 water gun seismic profiles illustrate active graben formation extending to Recent times in an area $170 \mathrm{n}$. mi. north of Site 588 . The healed microfaults are also strong evidence for the tectonic origin of most of these features. On the other hand, the interval is quite disturbed by rotary drilling, and a number of cracks are clearly artificial.

Unit II consists of siliceous foraminifer-bearing nannofossil chalks and foraminifer-bearing cherts. This unit was encountered only at the bottom of Hole $588 \mathrm{C}$, and less than one meter of it was recovered. This lithostratigraphic unit is characterized by the presence of siliceous sponge spicules, diatoms, and diagenetic chert. This unit coincides with Unit 2 of DSDP Site 208 (Burns, Andrews, et al., 1973). The color varies from light greenish gray to grayish yellow green. A few burrows occur in samples from Core 588C-19.

\section{PHYSICAL PROPERTIES}

Standard DSDP methods (Boyce, 1976; Boyce, 1977) were employed for the measurements of physical proper- ties at Site 588 (see Introduction and Explanatory Notes for specific techniques). The properties measured include sonic velocity, thermal conductivity, and calcium carbonate content. Wet-bulk density, grain density, and porosity were determined by gravimetric analyses, and saturated bulk density was also measured by GRAPE. All of the properties are analyzed and cross-correlated in detail by Morin (this volume).

The values of GRAPE porosity are derived from the GRAPE saturated bulk density results, assuming a grain density of $2.691 \mathrm{~g} / \mathrm{cm}^{3}$. This is a reasonable approximation, since the percentage of $\mathrm{CaCO}_{3}$ in the sediments is very high (Fig. 6A). The porosity data are plotted versus depth (points) in Figure 6B, and are subsequently averaged across each meter (solid line). GRAPE porosity for Holes 588 and $588 \mathrm{~A}$ is compared with that for Holes $588 \mathrm{~B}$ and $588 \mathrm{C}$ in Figure $6 \mathrm{C}$.

Compressional wave velocities demonstrate a sharp increase at the beginning of Hole 588C (Fig. 6D). These data are correlated with those of Figure $6 \mathrm{C}$ in an effort to establish a relationship between P-wave velocity and porosity (Fig. 6E). Combining the GRAPE bulk density profile with the sonic velocity values provides a plot of impedance versus depth (Fig. 6F). This latter figure depicts a smooth, gradual increase in impedance through the $488 \mathrm{~m}$ of the sediment column.

\section{SEISMIC STRATIGRAPHY}

Figure 7 illustrates portion of the shipboard water gun seismic profile collected during the approach to Site 588 . Five acoustic units (A, B, C, D, and E) have been identified, analogous to acoustic Units A to E of Willcox et al., 1980. Acoustic units are correlated with the lithology of Site 588, Units I and II.

Acoustic Unit A appears as an acoustically transparent layer at frequencies recorded on the seismic profile. Faint, coherent reflections occur down to $0.1 \mathrm{~s}^{4}$ sub-bottom.

Acoustic Unit B (the "chaotic" unit of Willcox et al., 1980) exhibits diffuse, sometimes coherent but generally chaotic reflections. A more reflective zone that occurs between 0.37 and $0.42 \mathrm{~s}$ sub-bottom can be traced for some tens of miles to the north on the underway water gun seismic profile.

Acoustic Unit C, comprising high-amplitude, relatively coherent reflectors, is a unit which can be identified throughout the region. The boundary between Unit C and overlying Unit B is relatively sharp. On the Lord Howe Rise, adjacent to and some $160 \mathrm{mi}$. north of Site 588 , the water gun profile shows major graben structures which appear to contain Unit $\mathrm{C}$ downfaulted into the grabens.

Acoustic Unit D comprises a high-amplitude, relatively coherent set of reflectors with an appearance similar to that of Unit C. Overlying basement lows (possible graben structures), Unit D is separated from overlying Unit $C$ by a lenticular low-amplitude graben-filling seismic unit (Fig. 7).

Acoustic Unit E is a low-amplitude (relatively transparent) zone overlying acoustic basement, a relationship

\footnotetext{
${ }^{4}$ Depths quoted in text as seconds below seafloor have been measured below Site 588 .
} 
Dominant lithology, Hole 588 A

\begin{tabular}{|c|c|c|c|c|c|c|c|c|c|c|c|c|c|c|c|c|c|c|c|c|c|c|c|}
\hline \multirow[b]{2}{*}{ 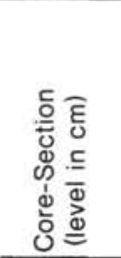 } & \multicolumn{7}{|c|}{ Biogenic components } & \multicolumn{8}{|c|}{ Nonbiogenic components } & \multicolumn{8}{|c|}{ Authigenic components } \\
\hline & 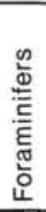 & $\begin{array}{l}\frac{\infty}{\bar{D}} \\
0 \\
\frac{0}{0} \\
\frac{0}{c} \\
\bar{c} \\
z\end{array}$ & 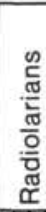 & $\begin{array}{l}\stackrel{0}{E} \\
\frac{\sigma}{\sigma} \\
\bar{\sigma}\end{array}$ & 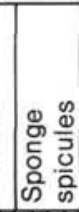 & 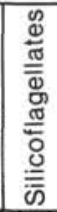 & $\begin{array}{l}0 \\
\frac{0}{2} \\
\frac{0}{0} \\
\frac{1}{0} \\
\frac{5}{4}\end{array}$ & $\begin{array}{l}\frac{N}{t} \\
\stackrel{0}{0} \\
0\end{array}$ & 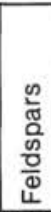 & 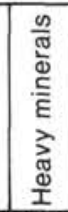 & 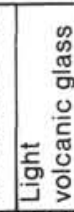 & 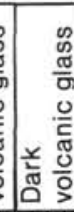 & 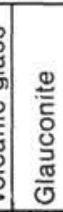 & $\begin{array}{l}\frac{\omega}{\pi} \\
\frac{\omega}{\Phi} \\
\frac{C}{E} \\
\frac{\pi}{0} \\
\frac{\pi}{0}\end{array}$ & $\begin{array}{l}\text { ఏ } \\
\text { ప }\end{array}$ & 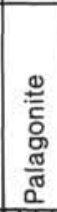 & 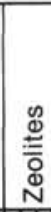 & 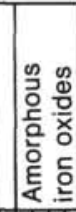 & 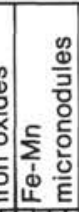 & 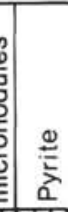 & 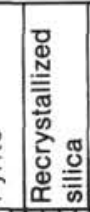 & 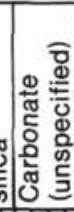 & 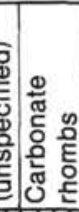 \\
\hline $1-2,83$ & & & & & $t$ & & & & & & & & & & & & & & & $t$ & & & \\
\hline $2-1,60$ & & & & & & & & & & & & & & & & & & & & & & & \\
\hline $2-1,130$ & & & & & & & & & & & $t$ & & & & & & & & & & & & \\
\hline $2-3,80$ & & & & & & & & & & & & & & & & & & & & & & & \\
\hline $3-2,77$ & & & & & & & & & & & & & & & & & & & & & & & \\
\hline $3-3,139$ & & & & & & & & $t$ & & & & & & & & & & & & & & & \\
\hline $4-3,70$ & & & & & & & & & & & & & & & & & & & & $t$ & & & \\
\hline $5-1,80$ & & & & & & & & & & & $t$ & & & & & & & & & & & & \\
\hline $6-2,60$ & & & & & & & & & & t & & & & & & & & & & $t$ & & & \\
\hline $7-1,80$ & & & & & & & & & & & $t$ & & & & & & & & & & & & \\
\hline $8-1,117$ & & & & & & & & & & & & & & & & & & & & & & & \\
\hline $8-2,55$ & & & & & & & & $t$ & & $t$ & & & & & & & & & & & & & \\
\hline $8-3,98$ & & & & & & & & $t$ & & $t$ & & & & & & & & & & & & & \\
\hline $9-1,80$ & & & & & & & & t & & t & & & & & & & & & & & & & \\
\hline $10-2,80$ & & & & & & & & t & & t & $t$ & & & & & & & & & & & & \\
\hline $11-2.63$ & & & & & & & & $t$ & & 1 & $t$ & & & & & & & & & & & & \\
\hline $12-1,31$ & & & & & & & & t & & $t$ & & & & & & & & & & & & & \\
\hline $12-3,84$ & & & & & & & & $t$ & & & & & & & & & & & & & & & \\
\hline $13-3,41$ & & & & & & & & t & & & & & & & & & & & & & & & \\
\hline $14-1,96$ & & & & & & & & t & & $t$ & & & & & & & & & & t & & & \\
\hline $15-1,74$ & & & & & & & & 7 & & & $t$ & & & & & & & & & & & & \\
\hline $16, \mathrm{CC}, 8$ & & & & & & & & $t$ & $\mathrm{t}$ & & $t$ & & & & & & & & & & & & \\
\hline $17-2,45$ & & & & & & & & & & $t$ & $t$ & & & & & & & & & & & & \\
\hline $18-1,70$ & & & & & & & & $t$ & & t & & & $t$ & & & & & & & & & & \\
\hline $18, \mathrm{CC}, 18$ & & & & & & & & & & & & & & & & & & & & & & & \\
\hline
\end{tabular}

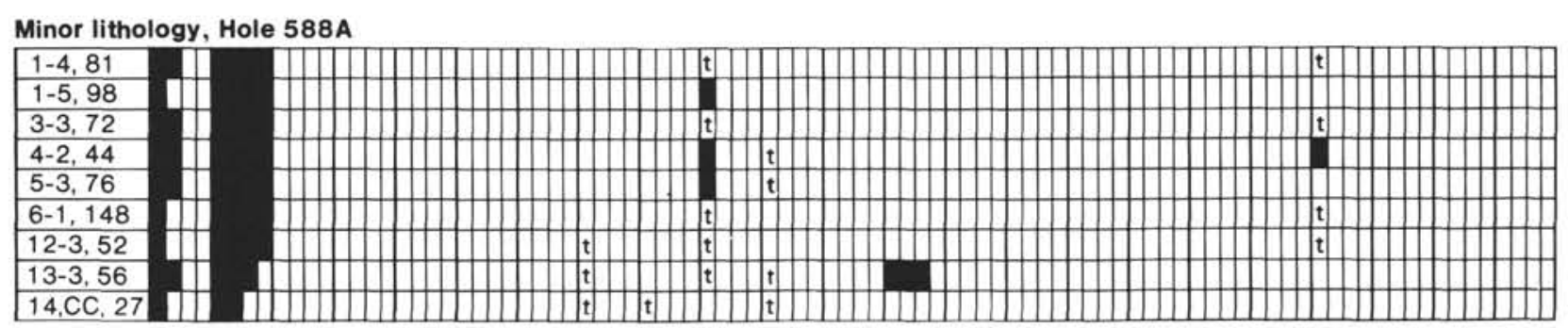

Figure 5. Smear slide summaries, Holes 588A, B, C.

which is not particularly evident in Figure 7. Similar to the transparent zone between Units $C$ and D, Unit E appears to be a graben-filling unit, showing an onlap relationship with basement. This unit is poorly represented or entirely absent over structural highs, where the highamplitude zones of Units C and D tend to coalesce.

Acoustic basement below Site 588 is inferred to lie at about 0.77 s sub-bottom.

Site 588 was drilled to a total depth of $488.1 \mathrm{~m}$ (Hole $588 \mathrm{C}$ ). The stratigraphic section is divided into two lithologic units.

Unit IA is an oxidized foraminifer-bearing nannofossil ooze of Quaternary age, restricted to the uppermost $6.8 \mathrm{~m}$ of section. Unit IB is a light-colored foraminiferbearing nannofossil ooze to nannofossil ooze, ranging in age from Quaternary to middle Miocene. Unit IC is a middle Miocene to upper Oligocene foraminifer-bearing nannofossil chalk to nannofossil chalk. Unit II comprises a siliceous foraminifer-bearing nannofossil chalk and chert.

An interval velocity of $1700 \mathrm{~m} / \mathrm{s}$ has been determined by averaging shipboard velocimeter mesurements on cores. The stratigraphic column in Figure 7 has been prepared using this velocity value. However, no positive correlation is apparent between acoustic and lithostratigraphic units, with the possible exception of the Eocene/Oligocene boundary. This boundary is obscured by an interval of strong reflections in the vicinity of Site 588 , but the left-hand extremity of the profile on Figure 7 shows a reflector which, on extrapolation to the site, may rep- 


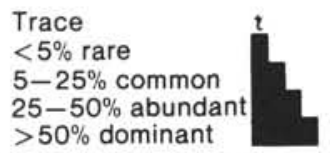

\begin{tabular}{|c|c|c|c|c|c|c|c|c|c|c|c|c|c|c|c|c|c|c|c|c|c|c|c|c|c|c|c|c|c|c|}
\hline \multirow[b]{2}{*}{ 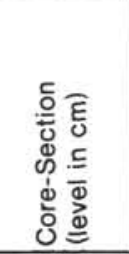 } & \multicolumn{8}{|c|}{ Biogenic components } & \multicolumn{12}{|c|}{ Nonbiogenic components } & \multicolumn{10}{|c|}{ Authigenic components } \\
\hline & 足 & 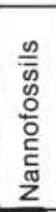 & $\begin{array}{l}\text { 음 } \\
\frac{\pi}{2} \\
\frac{\pi}{0} \\
\frac{0}{0} \\
\text { व }\end{array}$ & $\begin{array}{l}\stackrel{\infty}{0} \\
\frac{0}{\sigma} \\
\text { है }\end{array}$ & क & & 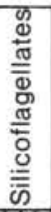 & 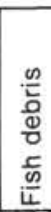 & & & $\begin{array}{l}\frac{\infty}{d} \\
\frac{2}{0} \\
\frac{0}{0} \\
\frac{0}{0} \\
4 \\
\end{array}$ & 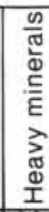 & & 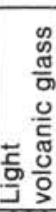 & & $\begin{array}{l}0 \\
0 \\
0 \\
0 \\
0 \\
\bar{c} \\
0 \\
0 \\
0\end{array}$ & 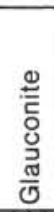 & व & 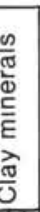 & $\begin{array}{l}\text { ఏ } \\
\text { ¿ }\end{array}$ & & 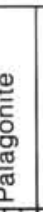 & 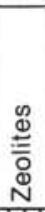 & 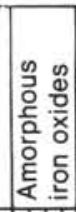 & 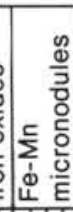 & 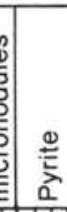 & & 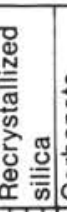 & 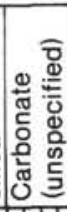 & : \\
\hline $1-1,28$ & & & & & t & & & & TI & & & & & & & & & & & & & & & & & & & & & \\
\hline $1-2,10$ & & & & & & & & & t & & & & & & & & & & & & & & & & & & & & & \\
\hline $1-2,68$ & & & & & $\mathrm{t}$ & & & & $t$ & & t & & & & & & & & & & & & & & & & & & & \\
\hline $1-3,68$ & & & & & & & & & $t$ & & & & & & & & & & & & & & & & & & & & & \\
\hline $1-4,67$ & & & & & & & & & t & & & & & & & & & & & & & & & & & & & & & \\
\hline $1-5,60$ & & & & & & & & & $t$ & & & & & & & & & & & & & & & & & & & & & \\
\hline $1-5,114$ & & & & & & & & & $t$ & & & & & & & & & & & & & & & & & & & & & \\
\hline $2-2,86$ & & & & & & & & & $t$ & & & & & & & & & & & & & & & & & & & & & \\
\hline $3-1,70$ & & & & & $t$ & & & & & & & & trat & $t$ & & & & & & & & & & & & & & & & \\
\hline $4-3,78$ & & & & & & & & & & & & & t & t & & & & & & & & & & & & & & & & \\
\hline $5-3,20$ & & & & & & & & & & & & & & & & & & & & & & & & & & & & & & \\
\hline $5-5,20$ & & & & & & & & & & & & $t$ & & & & & & & & & & & & & & & & & & \\
\hline $6-2,63$ & & & & & & & & & & & & $t$ & & & & & & & & & & & & & & & & & & \\
\hline $6-4,70$ & & & & & $t$ & & & & & & & & & & & & & & & & & & & & & & & & & \\
\hline $7-2,58$ & & & & & & & & & & & & $t$ & & & & & & & & & & & & & & & & & & \\
\hline $8-2,80$ & & & & & t & & & & & & & $t$ & & & & & & & & & & & & & & & & & & \\
\hline $9-1,80$ & & & & & t & & & & & & & & & & & & & & & & & & & & & t & & & & \\
\hline $10-1,110$ & & & & & $\mathrm{t}$ & & & & & & & & & & & & & & & & & & & & & 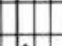 & & & & \\
\hline $11-2,79$ & & & & & & & & & & & & & & & & & t & & & & & & & & & t & & & & \\
\hline $12-2,85$ & & & & & & & & & & & & & & & & & & & & & & & & & & & & & & \\
\hline $13-3,84$ & & & & & t & & & & & & & $t$ & & & & & & & & & & & & & & & & & & \\
\hline $14-1,80$ & & & & & & & & & & & & t & & & & & & & & & & & & & & & & & & \\
\hline $15-2,90$ & & & & & $\mathrm{t}$ & & & & & & & t & & & & & & & & & & & & & & t & & & & \\
\hline $16-3,40$ & & & & & $t$ & & & & & & & $t$ & & & & & & & & & & & & & & $t$ & & & & \\
\hline $17-1,70$ & & & & & & & & & & & & t & & & & & & & & & & & & & & t & & & & \\
\hline $18-2,58$ & & & & & & & & & & & & & & t & & & & & & & & & & & & $t$ & & & & \\
\hline $19-1,65$ & & & & & & & & & & & & t & & & & & & & & & & & & & & $t$ & & & & \\
\hline $20-1,71$ & & & & & & & & & & & & & & & & & & & & & & & & & & & & & & \\
\hline $21-2,64$ & & & & & & & & & & & & $t$ & & & & & & & & & & & & & & & & & & \\
\hline $22-1,70$ & & & & & & & & & $t$ & & t & & & t & & & & & & & & & & & & & & & & \\
\hline $23-1,70$ & & & & & & & & & & & t & & & t & & & & & & & & & & & & & & & & \\
\hline $24-1,70$ & & & & & & & & & $t$ & & & & & $t$ & & & & & & & & & & & & & & & & \\
\hline $25-1,90$ & & & & & & & & & & & & & & t & & & & & & & & & & & & t & & & & \\
\hline $26-1,70$ & & & & & $t$ & & & & & & & & & $t$ & & & & & & & & & & & & & & & & \\
\hline $27-1,70$ & & & & & & & & & & & & & & & & & & & & & & & & & & & & & & \\
\hline $28-1,80$ & & & & & & & & & & & & & & & & & & & & & & & & & & & & & & \\
\hline $29-1,71$ & & & & & & & & & & & & & & & & & & & & & & & & & & & & & & \\
\hline $29-3,70$ & & & & & & & & & & & & & & & & & & & & & & & & & & & & & & \\
\hline $30-2,90$ & & & & & & & & & & & & & & & & & & & & & & & & & & & & & & \\
\hline $31-4,59$ & & & & & & & & & & & & & & & & & & & & & & & & & & & & & & \\
\hline
\end{tabular}

Minor lithology: Hole 588B

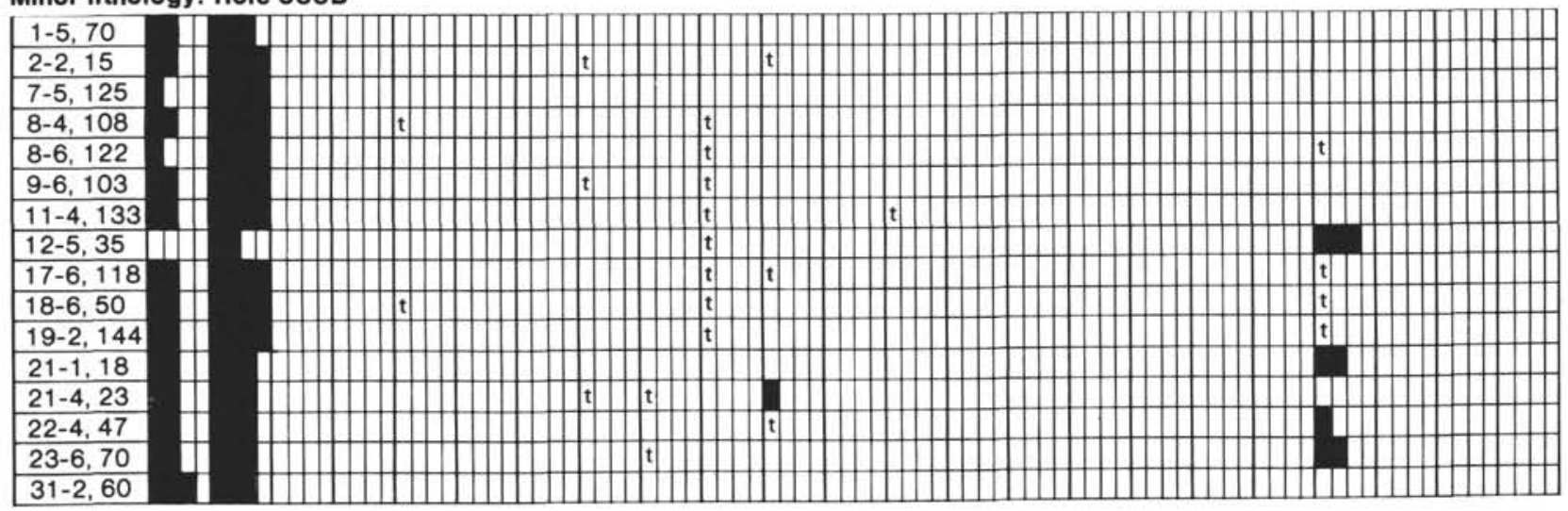

Figure 5. (Continued). 
Dominant lithology, Hole 588C

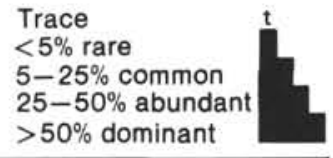

\begin{tabular}{|c|c|c|c|c|c|c|c|c|c|c|c|c|c|c|c|c|c|c|c|c|c|c|c|c|c|c|c|c|c|}
\hline \multirow[b]{2}{*}{ 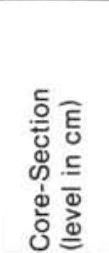 } & \multicolumn{8}{|c|}{ Biogenic components } & \multicolumn{11}{|c|}{ Nonbiogenic components } & \multicolumn{10}{|c|}{ Authigenic components } \\
\hline & 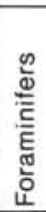 & 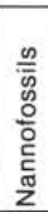 & 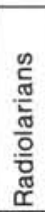 & $\begin{array}{l}\text { है } \\
\frac{0}{0} \\
\frac{\pi}{0}\end{array}$ & & $\begin{array}{l}\frac{9}{5} \\
\frac{5}{2} \\
\frac{0}{2} \\
\frac{0}{5}\end{array}$ & 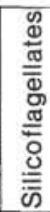 & $\begin{array}{l}\frac{0}{2} \\
\frac{0}{0} \\
\frac{5}{0} \\
\frac{5}{4}\end{array}$ & $\begin{array}{l}\frac{v}{2} \\
\mathbb{0} \\
0\end{array}$ & & $\begin{array}{l}\frac{\omega}{2} \\
\frac{0}{0} \\
\frac{0}{0} \\
\frac{0}{0} \\
\frac{0}{L}\end{array}$ & 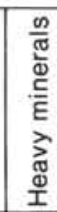 & & 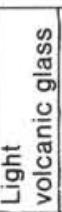 & 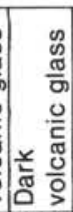 & 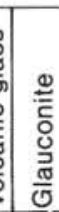 & & $\begin{array}{l}\frac{\omega}{\pi} \\
\frac{\pi}{\omega} \\
\frac{C}{E} \\
\frac{\pi}{U}\end{array}$ & $\frac{\mathbb{J}}{\Sigma}$ & 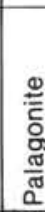 & & $\begin{array}{l}\stackrel{0}{ \pm} \\
\stackrel{ \pm}{0} \\
\stackrel{d}{N}\end{array}$ & 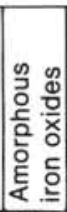 & 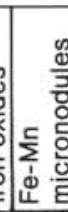 & పొ & ָֻ & 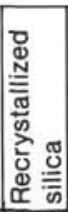 & 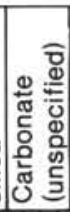 & 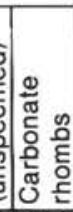 \\
\hline $1-2,80$ & & & & & & & & & $t$ & & $T$ & t & & & & & & & & & & & & & & & & & \\
\hline $1-3,75$ & & & & & & & & & & & & $t$ & & & & & & & & & & & & & & & & & \\
\hline $1-6,68$ & & & & & & & & & $t$ & & $t$ & $t$ & & & & & & & & & & & & & $t$ & & & & \\
\hline $2-1,74$ & & & & & & & & & 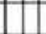 & & & $t$ & & & & & & & & & & & & & $t$ & & & & \\
\hline $2-2,60$ & & & & & & & & & 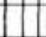 & & & $t$ & & & & & & & & & & & & & $\mathrm{t}$ & & & & \\
\hline $2-6,53$ & & & & & & & & & t & & & t & & & & & & & & & & & & & $t$ & & & & \\
\hline $3-1,80$ & & & & & & & & & $t$ & & & $t$ & t & & & & & & & & & & & & 更 & & & & \\
\hline $4-2,60$ & & & & & & & & & & & t & $t$ & & & & & & & & & & & & & $\theta$ & & & & \\
\hline $5-3,96$ & & & & & & & & & & & & & & & & & & & & & & & & & $\mathrm{t}$ & & & & \\
\hline $5-5,50$ & & & & & & & & & $t$ & & & & & & & & & & & & & & & & & & & & \\
\hline $6-3,131$ & & & & & & & & & $t$ & & & & & & & & & & & & & & & & & & & & \\
\hline $6-5,100$ & & & & & & & & & & & $t$ & & t & $t$ & & & & & & & & & & & & & & & \\
\hline $7-1,70$ & & & & & & & & & & & $t$ & & & & & & & & & & & & & & & & & & \\
\hline $8-2,70$ & & & & & & & & & & & & & & & & & & & & & & & & & & & & & \\
\hline $9-1,107$ & & & & & & & & & & & & & $t$ & & & & & & & & & & & & & & & & \\
\hline $10-2,70$ & & & & & & & & & & & $t$ & & t & & & & & & & & & & & & & & & & \\
\hline $12-1,70$ & & & & & $t$ & & & & & & & & t & & & & & & & & & & & & & & & & \\
\hline $13-1,80$ & & & & & & & & & & & & $t$ & & & & & & & & & & & & & & & & & \\
\hline $14-3.60$ & & & & & $t$ & & & & & & & & t & & & & & & & & & & & & & & & & \\
\hline $15-1,70$ & & & & & & & & & & & & & & & & & & & & & & & & & & & & & \\
\hline $16-1,57$ & & & & & $t$ & & & & $t$ & & & & & & & & & & & & & & & & & & & & \\
\hline $17-3,65$ & & & & & & & $t$ & & & & & $t$ & ti & & & & & & & & & & & & & & & & \\
\hline $18-1,50$ & & & & & & & & & & & & & & & & & & & & & & & & & & & & & \\
\hline
\end{tabular}

Minor lithology, Hole $588 \mathrm{C}$

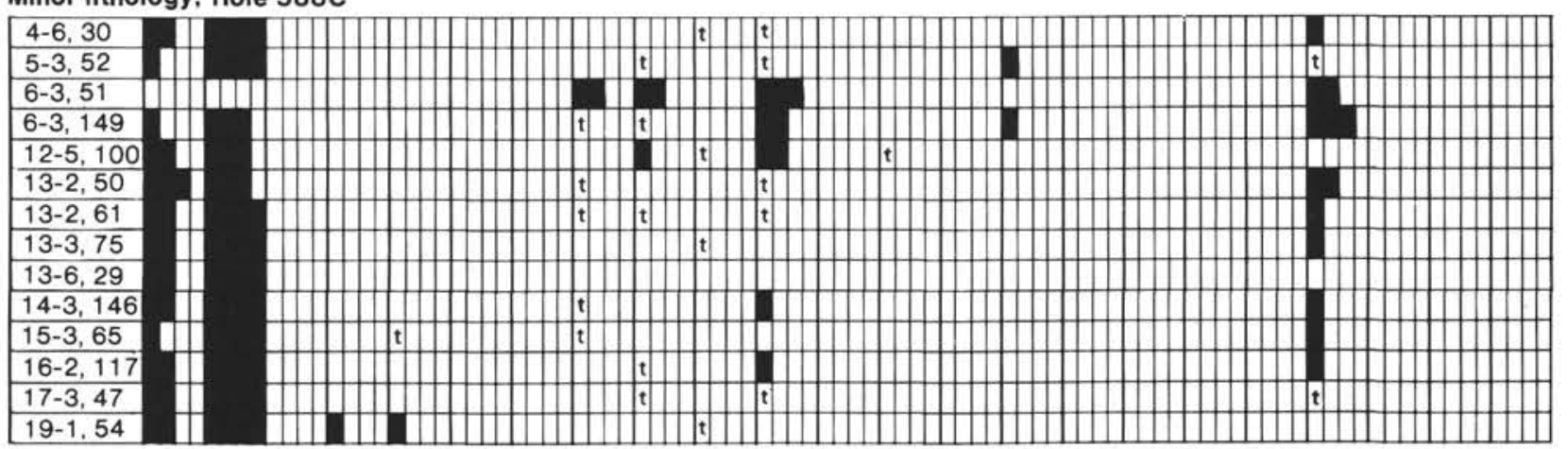

Figure 5. (Continued).

resent the onset of chert development in the middle Eocene; this in turn may correlate with the boundary between acoustic Units C and D.

\section{BIOSTRATIGRAPHY}

A complete calcareous sequence from the late Oligocene through Recent was recovered from the four holes drilled at Site 588. It is underlain by a siliceous-calcareous sequence of middle Eocene age from which it is separated by a disconformity at approximately $470 \mathrm{~m}$ subbottom. The deepest hole, Hole $588 \mathrm{C}$, was terminated at $488.1 \mathrm{~m}$ BSF in middle Eocene sediments. The completeness of the sequence, which is far superior to that in Hole 208 , drilled on Leg 21 , resulted in a very detailed planktonic foraminifer and calcareous nannoplankton zonation, and has provided material for an evaluation of the paleoenvironmental history of warm subtropical waters of the southern hemisphere during the late Oligocene to Recent. The calcareous sediments between 0 and about $470 \mathrm{~m}$ contain exclusively foraminifers, calcareous nannoplankton, calcareous dinoflagellates (calcispheres), and at certain levels also ostracodes and pteropods. Below the disconformity at $470 \mathrm{~m}$, down to the terminal depth of $488.1 \mathrm{~m}$, foraminifers and calcareous nannoplankton are associated with diatoms, radiolarians, silicoflagellates, ebridians, and sponge spicules in the middle Eocene.

Preservation of the calcareous fossils is excellent in the upper part of the sequence, and is fairly good for the foraminifers as well in the lower part of the calcare- 
ous sequence, where calcareous nannoplankton show considerable calcite overgrowth, especially in the upper Oligocene sediments. Preservation is good again for the calcareous nannoplankton in the middle Eocene, where the sequence contains a considerable amount of siliceous constituents. Calcareous nannoplankton and planktonic foraminiferal zones in the four holes of Site 588 are correlated in Figure 8.

\section{Foraminifers}

\section{Planktonic Foraminifers}

\section{Zones}

The zonal scheme used at Site 588 has been adapted from Kennett (1973) and Srinivasan and Kennett (1981a, b) (Fig. 9). The following changes have been made.

Globorotalia puncticulata Zone: It appears that the zonal marker made a late appearance at Site 588 as compared to the temperate sites of the southwest Pacific where it evolved; its immediate ancestor Globorotalia sphericomiozoa is not present.

Globorotalia plesiotumida Zone: At Site $588 \mathrm{G}$. conomiozea with a squarer outline in peripheral view made a late appearance within the range of the $G$. margaritae Zone and so the G. conomiozea Zone of Kennett (1973) and Srinivasan and Kennett (1981a, b) was not used. The G. plesiotumida Zone of the late Miocene is therefore equivalent to the lower part of their $G$. conomiozea Zone and the entire Globigerina nepenthes Zone.

Globorotalia fohsi s.1. Zone is equivalent to the upper part of the Orbulina suturalis Zone of Kennett (1973) and to the Globorotalia fohsi s.l. Zone and the G. peripheroacuta Zone of Srinivasan and Kennett (1981a, b). The main reason for "lumping" the zones together was the difficulty in consistently identifying the keeled $G$. fohsi in the upper part of the G. fohsi s.l. Zone at Site 588 .

The following zones have been added to the lower part of the sequence in the Oligocene.

Globigerina angulisuturalis Zone: This is a gap zone, with the base defined by the extinction of Chiloguembelina cubensis and the top by the first appearance of Globorotalia kugleri.

Chiloguembelina cubensis Zone: The top is defined by the extinction of the zonal marker and the base is undefined. The index species $G$. munda is present in the zone.

\section{Faunas}

Globorotalia truncatulinoides Zone: The zone fossil is common, as are Globigerina calida, Globorotalia inflata, G. menardii, G. tumida, and Pulleniatina obliquiloculata.

Globorotalia truncatulinoides-G. tosaensis Zone: The zone is marked by the overlap of the two zonal taxa, which are common in the zone. Other common species include $G$. inflata and Neogloboquadrina dutertrei.

Globorotalia tosaensis Zone: The zone fossil is abundant. There is evidence at the base of the zone of its evolution from $G$. crassaformis. Other important species in the zone include $P$. obliquiloculata and G. menardii; Globigerinoides extremus and Dentoglobigerina altispira became extinct in the lower part of the zone.

Globorotalia inflata Zone: The zone fossil is well represented in the zone, but its entry at the base was probably late compared with its evolutionary appearance further south in the southwest Pacific. Other species present include Globorotalia menardii, G. crassaformis, and Neogloboquadrina dutertrei.

Globorotalia crassaformis Zone: The zone fossil made a late appearance compared with its evolutionary appearance further south; other species present in the zone, included Globorotalia pliozea, which became extinct in the lower part of the zone, and Globigerina nepenthes.

Globorotalia puncticulata Zone: The zone fossil is rare in the zone and occurred with G. crassaformis, G. tumi$d a$, and $P$. primalis.

Globorotalia margaritae Zone: This zone is well represented with excellent faunas which include the zone fossil. Globorotalia cibaoensis became extinct within the zone and $P$. primalis made its entry in the lower part of the zone.

Globorotalia plesiotumida Zone: The zone fossil is comparatively rare. This was especially true in the lower part of the zone; other species in the zone include $G$. miotumida and $G$. menardii.

Neogloboquadrina continuosa Zone: The zone fossil is fairly rare within the zone and became extinct at the top of the zone; other important species include Candeina nitida, Globigerinatella aequilateralis, and N. nympha, the probable immediate ancestor of $N$. acostaensis; Globoquadrina dehiscens became extinct within the zone.

Globorotalia mayeri Zone: The zone fossil is fairly rare within the zone, which marks the first appearance of Neogloboquadrina; other species present include $G$. menardii, G. miotumida, and G. panda.

Globorotalia fohsi s.1. Zone: The zonal markers include $G$. peripheroacuta and $G$. fohsi s.l.; the latter form occurs sporadically throughout the zone. Both G. miotumida, G. panda, and $G$. menardii made their first appearance within the zone, whereas $G$. miozea became extinct.

Orbulina suturalis Zone: The zone fossil is common within the zone. Also present are G. peripheroronda and G. miozea.

Praeorbulina glomerosa curva Zone: The zone fossil is common within the zone, in association with G. praescitula, G. miozea, and $G$. siakensis.

Globorotalia miozea Zone: The zone fossil is common within the zone; other taxa include Globoquadrina dehiscens, Globorotalia praescitula, and $G$. peripheroronda, which made its initial appearance in the zone.

Catapsydrax dissimilis Zone: The zone fossil is common in the zone and occurs in association with $G$. semivera and $G$. siakensis.

Globoquadrina dehiscens Zone: The zone fossil is common within the zone and occurs in association with Globigerinoides primordius, G. altiaperturus, and Globorotalia kugleri.

Globigerinoides primordius Zone: The zone fossil is rare and occurs with Globigerina woodi, Globorotalia 

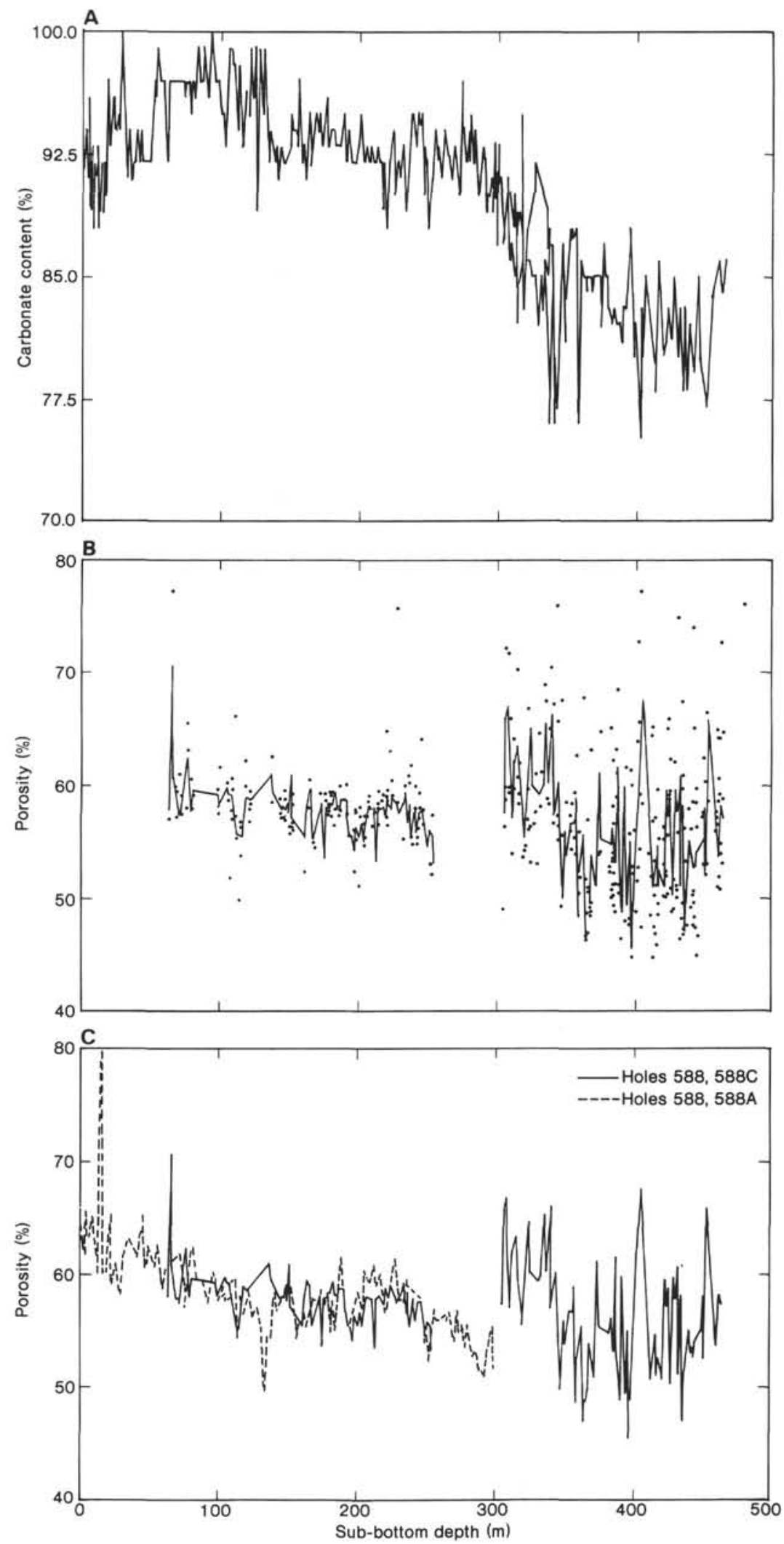

Figure 6. Physical properties, Site 588. A. Carbonate content versus sub-bottom depth for Site 588. B. GRAPE porosity versus sub-bottom depth for Holes 588B and 588C. C. GRAPE porosity versus sub-bottom depth for Holes 588, 588A, 588B and 588C. D. Compressional velocity versus sub-bottom depth for Site 588. E. Porosity versus compressional velocity for Site 588. F. Acoustic impedance versus sub-bottom depth for Site 588 . 

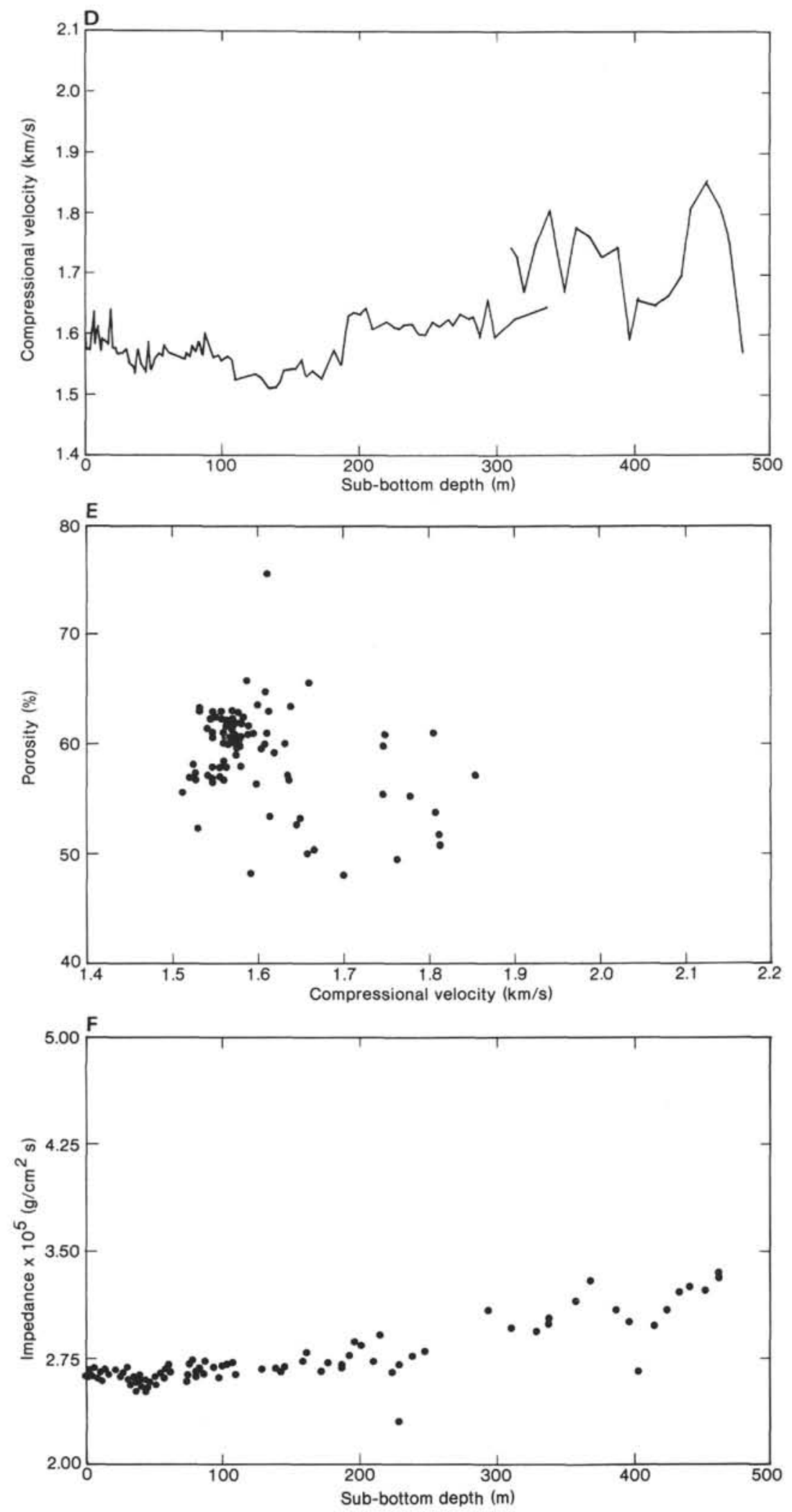

Figure 6. (Continued). 


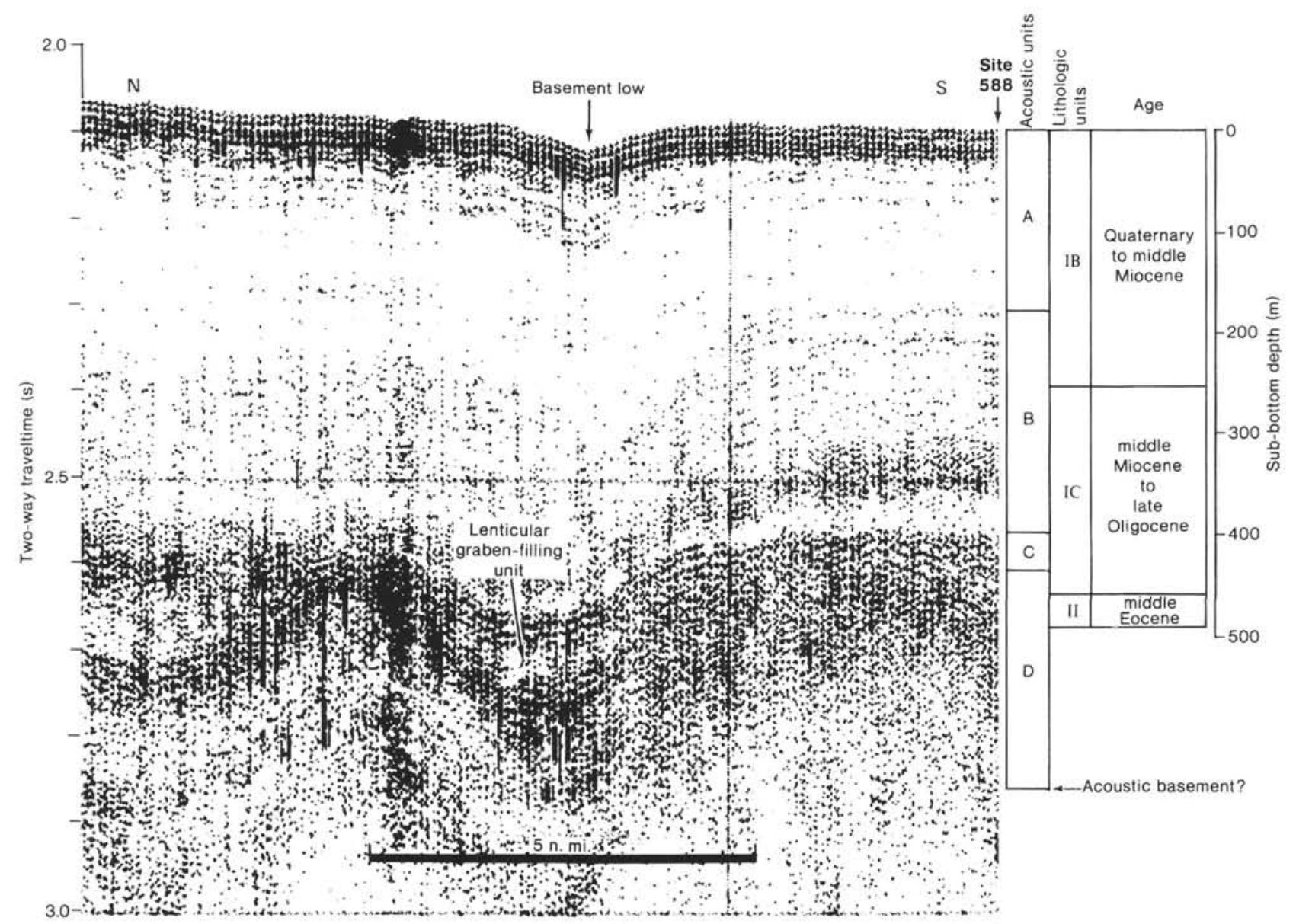

Figure 7. Comparison of acoustic Units A-E with lithologic Units I-II cored at Site 588; shipboard water gun seismic profile, collected during site approach; depths in meters estimated by assuming a sediment sound velocity of $1700 \mathrm{~m} / \mathrm{s}$.

kugleri, and Globoquadrina sp., the possible ancestor of $G$. dehiscens.

Globigerina angulisuturalis Zone: The zone fossil is common within the zone. The related species Globigerina ciperoensis is very rare. Other species present include G. euapertura, Globorotalia nana, Globorotaloides suteri, and Globorotalia testarugosa.

Chiloguembelina cubensis Zone: The zone fossil is common and occurs with G. munda; G. opima is rare.

\section{Paleobiogeography}

The late Oligocene yields a cosmopolitan fauna with an element of the southern cooler-water species such as Globigerina woodi and Globorotalia munda; the fauna lacks Globigerina ciperoensis and there are only a few specimens of Globorotalia opima.

The early Miocene was dominated by cooler-water southern taxa such as G. zealandica and G. miozea and marked by the absence of such warm-water forms as $\mathrm{Ca}$ tapsydrax stainforthi, Globigerinatella insueta, and Hastigerinella bermudezi.

The middle Miocene keeled Globorotalia fauna is dominated by the $G$. miotumida group and to a much lesser extent by $G$. menardii; the tropical $G$. fohsi lobata and G. fohsi robusta are absent.
The late Miocene appears to have been cooler, because of the predominance of the southern G. miotumi$d a$ group and the absence of such species as Pulleniatina primalis.

There was a marked change in fauna at about the Miocene/Pliocene boundary; G. conomiozea with a squarer outline in peripheral view became extinct and the tropical $G$. tumida appeared.

The Pliocene-Pleistocene forms were a mixture of warm subtropical-tropical species such as $G$. tumida, $G$. menardii, and $P$. obliquiloculata with a minor coolerwater element represented by $G$. inflata and Neogloboquadrina pachyderma.

\section{Major Stratigraphic Boundaries}

At this site the major boundaries were marked by the following species.

1. Pliocene/Pleistocene boundary: first appearance of Globorotalia truncatulinoides.

2. Miocene/Pliocene boundary: Kennett (1973) and Srinivasan and Kennett (1981a, b) placed the boundary at the first appearance of G. margaritae, which coincided with the extinction of $G$. conomiozea. In Site 588 we have, instead, observed overlapping ranges of G. margaritae and a local morphotype of $G$. conomiozea and have placed the boundary after the extinction of $G$. conomio- 

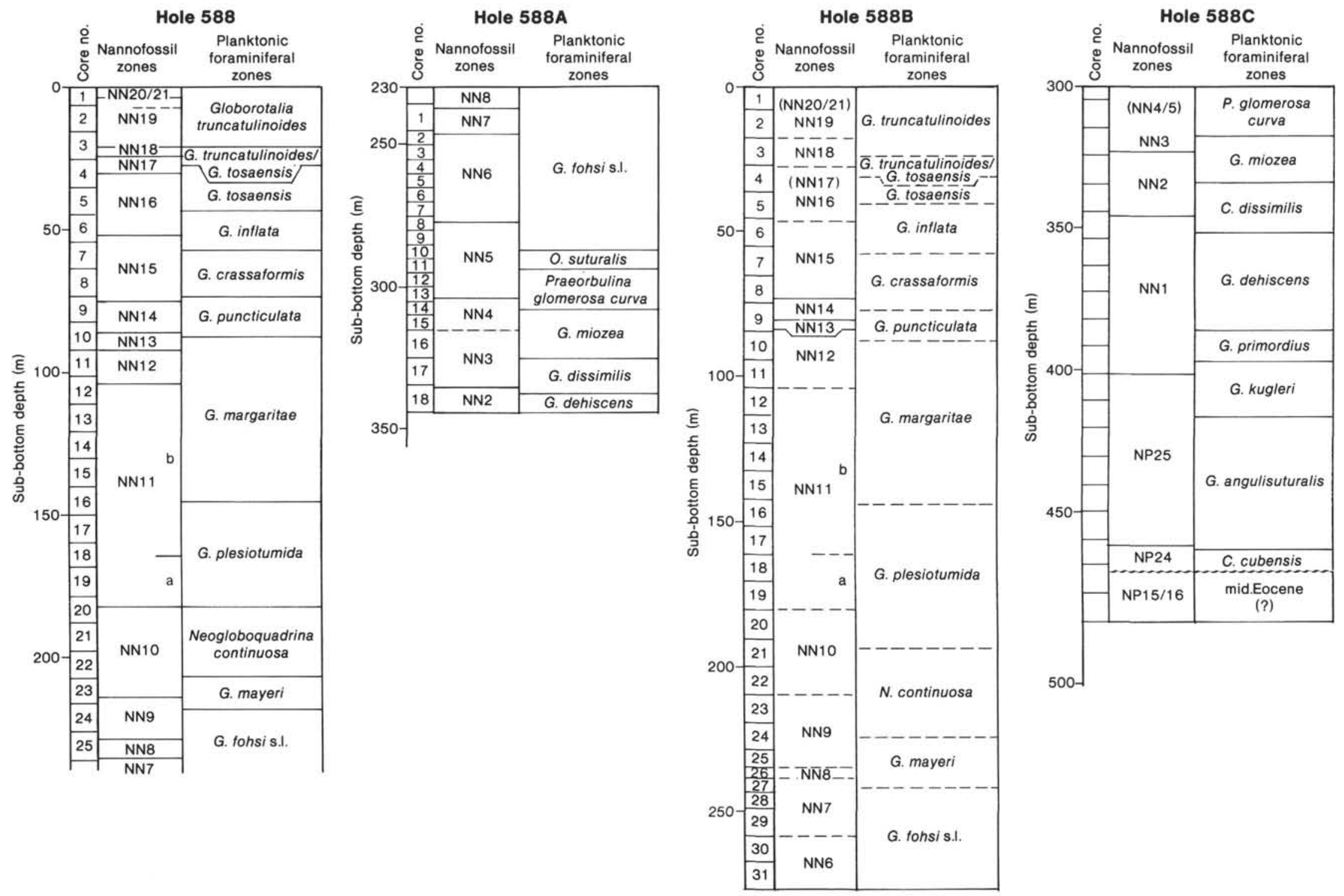

Figure 8. Biostratigraphy for Site 588. No radiolarians were encountered. 


\begin{tabular}{|c|c|c|c|}
\hline & $\begin{array}{c}\text { Kennett (1973): } \\
\text { warm subtropical } \\
\text { zones }\end{array}$ & $\begin{array}{c}\text { Srinivasan and } \\
\text { Kennett }(1981 \mathrm{a}, \mathrm{b})\end{array}$ & This volume \\
\hline \multirow[b]{2}{*}{ Pleistocene } & \multicolumn{2}{|c|}{ Globorotalia truncatulinoides } & G. truncatulinoides \\
\hline & $\begin{array}{c}\text { G. truncatulinoides- } \\
\text { G. tosaensis }\end{array}$ & $\begin{array}{c}\text { G. truncatulinoides- } \\
\text { G. tosaensis }\end{array}$ & $\begin{array}{c}\text { G. truncatulinoides- } \\
\text { G. tosaensis }\end{array}$ \\
\hline \multirow{3}{*}{$\begin{array}{l}\text { late } \\
\text { Pliocene }\end{array}$} & G. tosaensis & G. tosaensis & G. tosaensis \\
\hline & G. intlata & G. inflata & G. inflata \\
\hline & G. crassaformis & G. crassaformis & G. crassaformis \\
\hline \multirow{2}{*}{$\begin{array}{l}\text { early } \\
\text { Pliocene }\end{array}$} & G. puncticulata & G. puncticulata & G. puncticulata \\
\hline & G. margaritae & G. margaritae & G. margaritae \\
\hline \multirow{3}{*}{$\begin{array}{l}\text { late } \\
\text { Miocene }\end{array}$} & G. conomiozea & G. conomiozea & \multirow[b]{2}{*}{ G. plesiotumida } \\
\hline & Globigerina & nepenthes & \\
\hline & $\begin{array}{l}\text { Globorotalia } \\
\text { continuosa }\end{array}$ & $\begin{array}{l}\text { Neogloboquadrina } \\
\text { continuosa }\end{array}$ & N. continuosa \\
\hline \multirow{3}{*}{$\begin{array}{l}\text { middle } \\
\text { Miocene }\end{array}$} & G. mayeri & G. mayeri & G. mayeri \\
\hline & \multirow{2}{*}{$\begin{array}{l}\text { Orbulina } \\
\text { suturalis }\end{array}$} & $\begin{array}{l}\text { G. fohsis.l. } \\
\text { G. peripheroacuta }\end{array}$ & G. fohsi s.l. \\
\hline & & O. suturalis & 0 . suturalis \\
\hline \multirow{4}{*}{$\begin{array}{c}\text { early } \\
\text { Miocene }\end{array}$} & \multirow{4}{*}{$\begin{array}{c}\text { Globigerinoides } \\
\text { trilobus }\end{array}$} & \multicolumn{2}{|c|}{ Praeorbulina glomerosa curva } \\
\hline & & G. miozea & G. miozea \\
\hline & & \multicolumn{2}{|c|}{ Catapsydrax dissimilis } \\
\hline & & \multicolumn{2}{|c|}{ Globoquadrina dehiscens } \\
\hline \multirow{4}{*}{$\begin{array}{c}\text { late } \\
\text { Oligocene }\end{array}$} & & \multirow{2}{*}{\multicolumn{2}{|c|}{$\begin{array}{c}\text { Globigerinoides primordius } \\
\text { Globorotalia kugleri }\end{array}$}} \\
\hline & & & \\
\hline & & & G. angulisuturalis \\
\hline & & & $\begin{array}{c}\text { Chiloguembelina } \\
\text { cubensis }\end{array}$ \\
\hline
\end{tabular}

Figure 9. Planktonic foraminiferal zones used at Site 588.

$z e a$. This level also coincides with the first appearance of $G$. tumida.

3. Oligocene/Miocene boundary: first appearance of Globoquadrina dehiscens as in Srinivasan and Kennett (1981b, 1983).

\section{Benthic Foraminifers}

Benthic foraminifers were examined in aliquots of the fractions less than $63 \mu \mathrm{m}$ in core catchers from Holes $588,588 \mathrm{~A}$, and $588 \mathrm{C}$ (Table 3 ). The benthics are well preserved in most core catchers down to the lower Miocene (Section 588A-2 through Sample 588A-18,CC and $588 \mathrm{C}-8$ through $588 \mathrm{C}-19, \mathrm{CC})$. Below this point diagenetic alteration of the sediments has removed nearly $50 \%$ of the coarse fraction and, in the lower samples, a large percentage of the intermediate size-fraction as well.

From the top of the section down to the middle Miocene, faunas are very similar; they are dominated by species of Oridorsalis, Globocassidulina, Pullenia, and $\mathrm{Me}$ lonis. Diversity varies from a high of 25 species in the late Pliocene (Sample 588-6, CC) to a low of four species in a rich plankton ooze at the base of the Globorotalia plesiotumida Zone (Sample 588-19,CC). In general, both the diversity of the benthic faunas and the abundance of benthic specimens in the aliquots decrease down the section as the preservation of the carbonates worsens.

In the Pliocene (Samples 588-4 through 588-15,CC) there are three episodes of marked faunal change. In the G. inflata Zone (equivalent to the NN15/NN16 boundary in Sample 588-6,CC) there occurs a marked increase in both diversity and faunal abundance and many species disappear from the faunas. These include Anomalinoides semipunctata, Cibicides lobatulus, Osangularia culter, Karreriella bradyi, Hopkinsina mioindex, and Stilostomella insecta. Two of these species. O. culter and A. semipunctata, are very rare at this site, appear for a short time only in the lower and mid-Pliocene, and then disappear. Both $O$. culter and $A$. semipunctata were found at the shallow Site 587, but not at the deeper Site 586 . Their presence at the initiation of the glacial Pliocene at Site 588 may represent downward migration of these species and/or increased downslope movement of sediments.

A second episode of increased faunal abundance (Sample $588-8, C C$ ) in the G. crassaformis Zone is accompanied by the unusual appearance of two species, Pullenia quinqueloba and Melonis pompiliodes, which are typical of the faunas at the deeper Site 586, but do not appear in the faunas from the shallow Site 587. The rare appearances of these species, as in Sample 588-8,CC, may indicate upward migration of benthics because of some ecologic change. The proportions of other species in the samples need to be counted to test this idea.

In the top of the G. margaritae Zone (Sample 588$10, C C)$, there is an episode of faunal overturn involving the upward disappearance of several important species: Ehrenbergina pacifica, Uvigerina spinulosa, and Rectuvigerina multistriata, among others. At the shallower Site $587, R$. multistriata disappears later, at the beginning of the glacial (=NN15/NN16).

In the Miocene there are also three episodes of marked faunal change: at the base of the Neogloboquadrina continuosa Zone, in the G. fohsi s.l. Zone, and in the G. miozea Zone. Otherwise the Miocene faunas are very consistent. Diversity and faunal abundance are consistent except in those poorly preserved samples lower in the section. Very few new species appear above the base of the middle Miocene.

Toward the base of the $N$. continuosa Zone (Cores 588-21 through 588-23) there is a second influx of $M$. pompilioides, $P$. quinqueloba, and several other species suspected of representing a deeper faunal influence. There is no apparent change in benthic diversity or abundance during this faunal change.

Faunal changes in the G. fohsi s.l. Zone (Samples $588 \mathrm{~A}-2$ through $588 \mathrm{~A}-9$ and $588 \mathrm{C}-1$ through $588 \mathrm{C}-9$ ) are difficult to evaluate because carbonate preservation worsens in this zone. Diversity and faunal abundances are generally lower than in overlying samples. The character of faunas alters slightly because Ehrenbergina spp., small virgulinids, large nodosarids and Quinqueloculina increase in abundance upward. The significance of these forms is not known. In addition, several species disappear from the faunas at this time; these include Heterolepa trinitatensis, Siphonodosaria modesta, Bulimina tuxpamensis, $B$. semicostata, and Cibicidoides sp. Upward migration of benthic species is not evident in the material seen so far.

The elimination of typical Eocene-Oligocene benthic species occurs in the base of the G. miozea Zone (588A-15 to $588 \mathrm{~A}-16, \mathrm{CC}$ ). In these samples both faunal abundance and diversity are highest for the early Miocene. Species which terminate in this zone are Planulina renzi, Sipho- 
nina pulchra, $H$. hunteri, B. jarvisi, O. mexicana, and Plectofrondicularia sp.

The lowermost Miocene and the Oligocene at Holes $588 \mathrm{~A}$ and $588 \mathrm{C}$ cannot be compared with overlying sediments because of the degree of dissolution in the older samples. In both holes sediments of this age have lost nearly $50 \%$ of their coarse fractions, including a large percentage of benthic species. In the Oligocene (588C-9 through $588 \mathrm{C}-17, \mathrm{CC}$ ) the intermediate size-fraction is also largely missing. Glauconite is occasionally present and a large proportion of the fossils are fragmented. Benthic species present include Oridorsalis umbonatus, Globocassidulina subglobosa, C. tuxpamensis, Pullenia coryelli, B. semicostata, and $P$. quadriloba.

\section{Calcareous Nannoplankton}

Core-catcher samples along with enough additional samples to determine zonal boundaries were examined for calcareous nannoplankton. All zonal indicators are present, with the exception of Helicosphaera ampliaper$t a$. The upper boundary of the Helicosphaera ampliaperta Zone (NN4) is determined instead by the first occurrence of Discoaster exilis. Calcareous nannoplankton are abundant and well preserved throughout the upper part of the section.

\section{Hole 588}

\section{Pleistocene}

The presence of Emiliania huxleyi in Sample 588-1-1, $85-86 \mathrm{~cm}$ places this sample in the late Pleistocene Emiliania huxleyi Zone (NN21). Sample 588-1-2, 85-86 cm is placed in the late Pleistocene Gephyrocapsa oceanica Zone (NN20). The presence of $E$. ovata and the absence of Calcidiscus macintyrei in Samples 588-1-3, 85-86 cm and 588-1,CC place these samples in the upper subzone of the early Pleistocene E. ovata Zone (NN19b). The addition of $C$. macintyrei in Samples 588-2-1, 85-86 cm to $588-3-4,0-1 \mathrm{~cm}$ places these samples in the lower subzone of the $E$. ovata Zone (NN19a).

\section{Pliocene}

The last occurrence of Discoaster brouweri in Sample $588-4-2,0-1 \mathrm{~cm}$ and the last occurrence of $D$. pentaradiatus in Sample 588-3,CC place Samples 588-3-5, 0-1 cm and 588-4-1, 0-1 cm in the late Pliocene Discoaster brouweri Zone (NN18). The presence of $D$. brouweri together with $D$. pentaradiatus in Sample 588-4-2, 0-1 cm places this sample in the late Pliocene $D$. pentaradiatus Zone (NN17).

The last occurrence of Reticulofenestra pseudoumbilica in Sample 588-6-6, 0-1 cm places Samples 588-4-3, $0-1 \mathrm{~cm}$ to $588-6-5,0-1 \mathrm{~cm}$ in the late Pliocene Discoaster surculus Zone (NN16). Samples 588-6-6, 0-1 cm to 588-9-2, 0-1 cm, above the last occurrence of Amaurolithus tricorniculatus, are placed in the early Pliocene Reticulofenestra pseudoumbilica Zone (NN15). The interval from Sample 588-9-3, 0-1 cm to the first occurrence of D. asymmetricus in Sample $588-11-1,0-1 \mathrm{~cm}$ is placed in the early Pliocene $D$. asymmetricus Zone (NN14). The interval from Sample 588-11-2, 0-1 cm to the first occurrence of Ceratolithus rugosus in Sample $588-11-3,0-1 \mathrm{~cm}$ in placed in the early Pliocene Ceratolithus rugosus Zone (NN13). The early Pliocene Amaurolithus tricorniculatus Zone (NN12) includes Samples $588-11-4,0-1 \mathrm{~cm}$ to $588-12-1,0-1 \mathrm{~cm}$ above the last occurrence of $D$. quinqueramus.

\section{Miocene}

The last occurrence of Discoaster quinqueramus in Sample 588-12-2, $0-1 \mathrm{~cm}$ and the first occurrence of Amaurolithus primus in Sample 588-18-3, 0-1 cm places Samples 588-12-2, 0-1 cm to 588-18-3, 0-1 cm in the upper subzone of the late Miocene Discoaster quinqueramus Zone (NN11b). The interval from Sample 588-18$4,0-1 \mathrm{~cm}$ to the first occurrence of $D$. quinqueramus in Sample 588-20-7, 0-1 cm is placed in the lower subzone of the late Miocene $D$. quinqueramus Zone (NN11a). Samples $588-20, C C$ to $588-23-4,0-1 \mathrm{~cm}$, above the last occurrence of $D$. hamatus, are placed in the late Miocene $D$. calcaris Zone (NN10).

The middle Miocene D. hamatus Zone (NN9) includes Samples $588-23-5,0-1 \mathrm{~cm}$ to $588-25-3,0-1 \mathrm{~cm}$, based upon the occurrence of $D$. hamatus. The interval from Sample 588-25-4, 0-1 cm to the first occurrence of Catinaster coalitus in Sample 588-25-6, 0-1 cm is placed in the middle Miocene Catinaster coalitus Zone (NN8). Sample $588-25, C C$ is placed in the middle Miocene $D . k u$ gleri Zone (NN7). Hole 588 was terminated at a depth of $236.0 \mathrm{~m}$ BSF.

\section{Hole 588A}

Hole 588A continues downsection from where Hole 588 ended. However, the presence of Catinaster coalitus in Sample 588A-1-1, 0-1 cm suggests a slight stratigraphic overlap between the two holes, because its apparent first occurrence was in Sample 588-25-6, 0-1 cm. The middle Miocene Discoaster kugleri Zone (NN7) is continued from Sample 588A-1-2, 0-1 cm to the first occurrence of Discoaster kugleri in Sample 588A-2-4, 0-1 cm. The interval from Samples 588A-2,CC to 588A-8,CC, above the last occurrence of Sphenolithus heteromorphus in Sample 588A-9-1, 0-1 cm, is placed in the middle Miocene $D$. exilis Zone (NN6). the interval from Sample 588A-9-1, 0-1 cm to the first occurrence of $D$. exilis in Sample 588A-12,CC is placed in the middle Miocene Sphenolithus heteromorphus Zone (NN5). The early Miocene Helicosphaera ampliaperta Zone (NN4) includes Samples 588A-13,CC to 588A-15,CC, above the last occurrence of $S$. belemnos in Sample 588A-16,CC. The interval from Samples $588 \mathrm{~A}-15, \mathrm{CC}$ to $588 \mathrm{~A}-17, \mathrm{CC}$, above the last occurrence of Triquetrorhabdulus carinatus in Sample $588 \mathrm{~A}-18-1,0-1 \mathrm{~cm}$, is placed in the early Miocene $S$. belemnos Zone (NN3). Samples 588A-18-1, 0-1 $\mathrm{cm}$ and 588A-18,CC are placed in the early Miocene $D$. druggii Zone (NN2). Hole 588A was terminated at a depth of $344.4 \mathrm{~m}$ BSF.

\section{Hole 588B}

Hole 588B duplicates all of Hole 588 and the upper part of Hole $588 \mathrm{~A}$; therefore, only the 31 core-catcher samples were examined. The zonal boundaries (NN21/ 
NN6) encountered in this hole are essentially the same as those of Holes 588 and $588 \mathrm{~A}$. Hole $588 \mathrm{~B}$ was terminated at a depth of $277.4 \mathrm{~m}$ BSF.

\section{Hole 588C}

Hole $588 \mathrm{C}$ stratigraphically overlaps the lower part of Hole 588A and begins with Sample 588C-1,CC in the middle Miocene Sphenolithus heteromorphus Zone (NN5). The interval from Sample 588C-2-1, 0-1 cm, below the first occurrence of Discoaster exilis in Sample 588C$1, \mathrm{CC}$ to $588 \mathrm{C}-2-5,0-1 \mathrm{~cm}$ above the last occurrence of Sphenolithus belemnos in Sample 588C-2-6, 0-1 cm is placed in the early Miocene Helicosphaera ampliaperta Zone (NN4). The presence of $S$. belemnos and the absence of Triquetrorhabdulus carinatus in the interval from Sample 588C-2-6, 0-1 cm to 588C-3-6, 0-1 cm places these samples in the early Micene $S$. belemnos Zone (NN3). The interval from the last occurrence of $T$. carinatus in Sample 588C-3,CC and the first occurrence of D. druggii in Sample 588C-5-1, 21-22 cm is placed in the early Miocene Discoaster druggii Zone (NN2). Samples $588 \mathrm{C}-5-2,0-1 \mathrm{~cm}$ to $588 \mathrm{C}-10, \mathrm{CC}$, above the late Oligocene in Sample 588C-10-4, 0-1 cm, are placed in the early Miocene Triquetrorhabdulus carinatus Zone (NN1).

The Oligocene/Miocene boundary, taken at the base of nannoplankton Zone NN1 ( $T$. carinatus Zone) was encountered at approximately $400 \mathrm{~m}$ sub-bottom in Hole 588C. The last occurrences of Helicosphaera recta, Sphenolithus ciperoensis, and Zygrhablithus bijugatus were found in the lower part of Core 588C-10. In 588C-17 S. distentus and $S$. predistentus occur together with $S$. ciperoensis, indicating the presence of Zone NP24 (Sphenolithus distentus Zone).

Sphenoliths are not very common in the late Oligocene at this site, but this may be the result of the poor preservation in certain levels. Z. bijugatus, which is known to occur in shallow water, is rather common in the entire late Oligocene. Rare reworked Eocene nannoplankton were found in most late Oligocene samples.

At the top of Core $588 \mathrm{C}-18$, a disconformity was noted between the upper and middle Eocene. The Eocene assemblage, also present in the lowest Core $588 \mathrm{C}-19$, contains, among others, D. barbadiensis, Reticulofenestra umbilica, Chiasmolithus solitus, Neococcolithus dubi$u s$, and $C$. grandis, indicating a position within nannoplankton Zones NP15 (Chiphragmalithus alatus Zone) and NP16 (D. tani nodifer Zone). In the late Oligocene, the calcareous nannoplankton is heavily overgrown by secondary calcite, discoasters showing alternating rays fused together and sphenoliths partly fragmented in certain levels. The preservation of calcareous nannoplankton in the middle Eocene is fairly good again, probably because siliceous biogenic constituents, are present.

\section{Diatoms and Silicoflagellates}

Diatoms and silicoflagellates were found only in the middle Eocene part of Hole 588C (Cores 588C-18 and $588 \mathrm{C}-19)$ and are associated with ebridians and sponge spicules. Diatoms are especially common in Core 588C-19, and include representatives of the genera Triceratium,
Actinoptychus, Trochosira, and Thalassiosira among the well-diversified assemblage. Silicoflagellates were encountered in several samples of 588C-19. The assemblage, containing Naviculopsis foliacea and Corbisema spino$s a$, can be placed in the middle Eocene Naviculopsis foliacea Zone.

\section{Radiolarians}

Radiolarians occur only in the middle Eocene part of Hole 588C (Cores 18 and 19).

\section{PALEOMAGNETISM}

All well-preserved core sections (i.e., those not fluid or obviously deformed) from Holes 588, 588A, and 588B were measured on the shipboard Digico long-core spinner magnetometer. Apart from the regions of higher intensity (discussed below), the signal was not sufficiently above the noise and contamination levels to give reproducible results in adjacent cores. Long-core measurements were discontinued after this site.

Holes 588, 588A, and 588C were subsampled at two specimens per section (usually), and Hole 588B at one specimen per section. Laboratory NRM measurements have been completed on Holes 588 and 588A (Barton and Bloemendal, this volume). Absolute orientations were attempted on most cores using the Kuster tool, with results as follows: for Hole 588, 21 attempts, 15 successes; for Hole 588A, 8 attempts, all successful; for Hole 588B, 16 attempts, 9 successes and 2 suspect results. This success rate is better than has often been obtained but still needs to be improved.

Intensities of magnetization were generally very low, though noticeably higher than for previous sites on this leg. NRM statistics for the sequence measured are presented in Table 3.

In common with other sites, there is a high-intensity zone $(1-\sim 15 \mu \mathrm{G})$, at the top of the sequence, but here it is longer, extending to the bottom of Core 588-4. Intensities then become extremely weak (typically $0.05 \mu \mathrm{G}$ ), with high directional scatter down to Core 588-21 near the mid/late Miocene boundary. Below this, intensities increase monotonically to values of around $15 \mu \mathrm{G}$ at the bottom of the section. Prominent intensity spikes were common in the sequence. The most obvious ones in the subsample data are listed in Table 4 . There was no general correlation between these "high" intensity spikes and the occurrence of ash layers and iron sulfide nodules. One exception was the prominent ash layer in Core 588$23-2,145 \mathrm{~cm}$. Iron sulfide nodules removed from various cores had only weak magnetic moments, sometimes barely higher than that of the surrounding sediments. This suggests that pyrrhotite, the only common ferromagnetic iron sulfide, is not a major component.

Table 3. NRM statistics at Site 588 .

\begin{tabular}{lcc}
\hline & Hole 588 & Hole 588A \\
\hline Geometric mean intensity $(\mu \mathrm{G})$ & 0.150 & 1.552 \\
Scalar mean inclination & $-5.0 \pm 39.7^{\circ}$ & $-6.7 \pm 51.6^{\circ}$ s.d. \\
Axial dipole inclination & $-44.4^{\circ}$ & - \\
Mean angle between repeats & $4.6^{\circ}$ & - \\
\hline
\end{tabular}


Table 4. Prominent magnetization intensity spikes observed in Hole 588.

\begin{tabular}{lrr}
\hline $\begin{array}{c}\text { Core-Section } \\
\text { (level in } \mathrm{cm})\end{array}$ & $\begin{array}{c}\text { Depth } \\
(\mathrm{m})\end{array}$ & \multicolumn{1}{c}{$\begin{array}{c}\text { Intensity } \\
(\mu \mathrm{G})\end{array}$} \\
\hline $2-1,25$ & 5.85 & 14.548 \\
$2-5,100$ & 12.60 & 3.275 \\
$4-5,125$ & 32.05 & 3.044 \\
$5-7,125$ & 44.65 & 1.368 \\
$9-1,25$ & 73.05 & 0.308 \\
$9-5,25$ & 79.05 & 0.283 \\
$11-3,125$ & 96.25 & 0.215 \\
$11-6,25$ & 99.75 & 0.383 \\
$12-6,125$ & 110.35 & 0.523 \\
$13-1,25$ & 111.45 & 0.916 \\
$13-2,125$ & 113.95 & 0.327 \\
$14-3,25$ & 124.05 & 0.468 \\
$14-6,125$ & 129.55 & 0.388 \\
$19-6,125$ & 177.55 & 0.443 \\
$21-3,125$ & 192.25 & 0.341 \\
$23-2,25$ & 208.95 & 1.642 \\
\hline \multicolumn{3}{c}{ Note: Other spikes were apparent in } \\
the long-core records.
\end{tabular}

It was possible to identify a polarity stratigraphy only down to the end of the Gilbert Chron (Fig. 10A). Below this, to the top of the high-intensity zone (around Core 588-22), directions were more scattered and no unambiguous polarity interpretation was possible. It may be possible to improve on this when results from the adjacent HPC become available. Below Core 588-21 it was again possible to identify a polarity stratigraphy (Fig. 10A), but it is not clear how this should be matched to the polarity time scale. The very long normal-polarity interval in Cores 588-24 and -25 would appear to correspond to Chron 9 (8.92 to 10.42 m.y.), but this interpretation conflicts with the foraminifer and nannoplankton zones. The quality of the paleomagnetic record deteriorates markedly in the denser sediments cored with the 5-m HPC in Hole 588A, despite the high intensities. Directional scatter is high and there is a marked negative (normal) bias to inclinations, suggesting viscous overprinting in the present-day field. No polarity interpretation was possible for Hole 588A.

The increase in intensity at the top of the section is presumably due to the reasons discussed in the Introduction. The origin of higher intensities prior to the late Miocene is not clear. Two possibilities are (1) enhanced input of terrigenous material, and (2) inhibition of the reducing conditions which are probably responsible for the falloff in intensity as a function of depth at the top of the section.

\section{SEDIMENTATION RATES}

Sedimentation rates were calculated from calcareous nannoplankton zonal boundaries for the four holes drilled at Site 588. Hole 588B (Fig. 11C) duplicated the results from Hole 588. However, since zonal boundaries in Hole 588B were based only on core-catcher samples, sedimentation rates for this particular hole are less reliable than those for the other three holes.

Ages of nannoplankton boundaries used to determine sedimentation rates are the same as those used during Leg 59 (Martini, 1981) with some minor improvements.
Middle Eocene sedimentation rates could not be calculated in the calcareous-siliceous sediments, because the section (Cores $588 \mathrm{C}-17$ and $588 \mathrm{C}-18$ ) was too short and no zonal boundaries were detected.

In the late Oligocene to early Miocene interval (Hole $588 \mathrm{C}$, nannoplankton Zones NN2 top to NN24 top), the sedimentation rate is $20.6 \mathrm{~m} / \mathrm{m}$.y. in calcareous sediments, based on four boundary datums (Fig. 12D). The mean sedimentation rate in the early Miocene (Hole 588A, nannoplankton Zones NN2 top to NN7 top), based on six boundary datums, shows a slight decrease to $14.4 \mathrm{~m} /$ m.y., also in calcareous sediments (Fig. 11B). The sedimentation rate in the middle Miocene to early Pliocene interval (Hole 588, nannoplankton Zones NN7 top to NN13 top) is constant at $17.4 \mathrm{~m} / \mathrm{m}$.y., based on six datum levels (Fig. 11A). In the late Pliocene (Hole 588, nannoplankton Zones NN13 top to NN18 top) the sedimentation rate increases rather abruptly to $29.5 \mathrm{~m} / \mathrm{m}$.y., and drops off to only $12.2 \mathrm{~m} / \mathrm{m}$.y. in the Quaternary interval (Hole 588, above nannoplankton Zone NN18 top), both in calcareous sediments. The two latter sedimentation rates are based on eight datum levels (Fig. 11A). The comparatively low sedimentation rate in the Quaternary may be unreliable, and may have resulted from drilling disturbance in the uppermost layers or from winnowing of finer sediments.

\section{SUMMARY AND CONCLUSIONS}

Site 588 was drilled at the same location as Site 208 in order to obtain a high-quality, continuously cored sequence through the late Paleogene and Neogene. Previous investigations have demonstrated that the planktonic foraminiferal assemblages at this latitude are made up of both tropical and temperate elements. At the present time, Site 588 is located in the warm subtropical water mass which lies between the true tropical water masses to the north and transitional water masses to the south. However, Site 588 experienced $5-10^{\circ}$ of northerly movement during the Neogene in association with movements of the Indian Plate (Sclater et al., in press). During the early Miocene, Site 588 was located at about $36^{\circ} \mathrm{S}$ in the present-day temperate area and within the zone of westerly winds. This northward movement from higher to lower latitudes must have had a major effect upon the biogeography of the planktonic microfossil assemblages.

Site 588 consists of four holes (Fig. 12): Hole 588, cored continuously with the HPC from $0-236.0 \mathrm{~m}$ subbottom; Hole $588 \mathrm{~A}$, cored continuously with the HPC from 236.0-344.4 m; Hole 588B, cored continuously with the HPC from 0-277.4 m; and Hole $588 \mathrm{C}$ cored continuously with the rotary drill from $305.7-488.1 \mathrm{~m}$ subbottom.

The HPC sequence through carbonate sediments is a record penetration of $315 \mathrm{~m}$, extending from the Quaternary to the late early Miocene at $17 \mathrm{~m}$.y. (Zone NN3 or Globorotalia miozea Zone). The overlapping hydraulic piston cores effectively provide $100 \%$ recovery of this sequence (Fig. 12). There is particularly good core quality in the Miocene, much less so in the Pliocene, and especially poor quality in the Quaternary, which is soupy. The carbonate fossil sequence is exquisite through the 
A

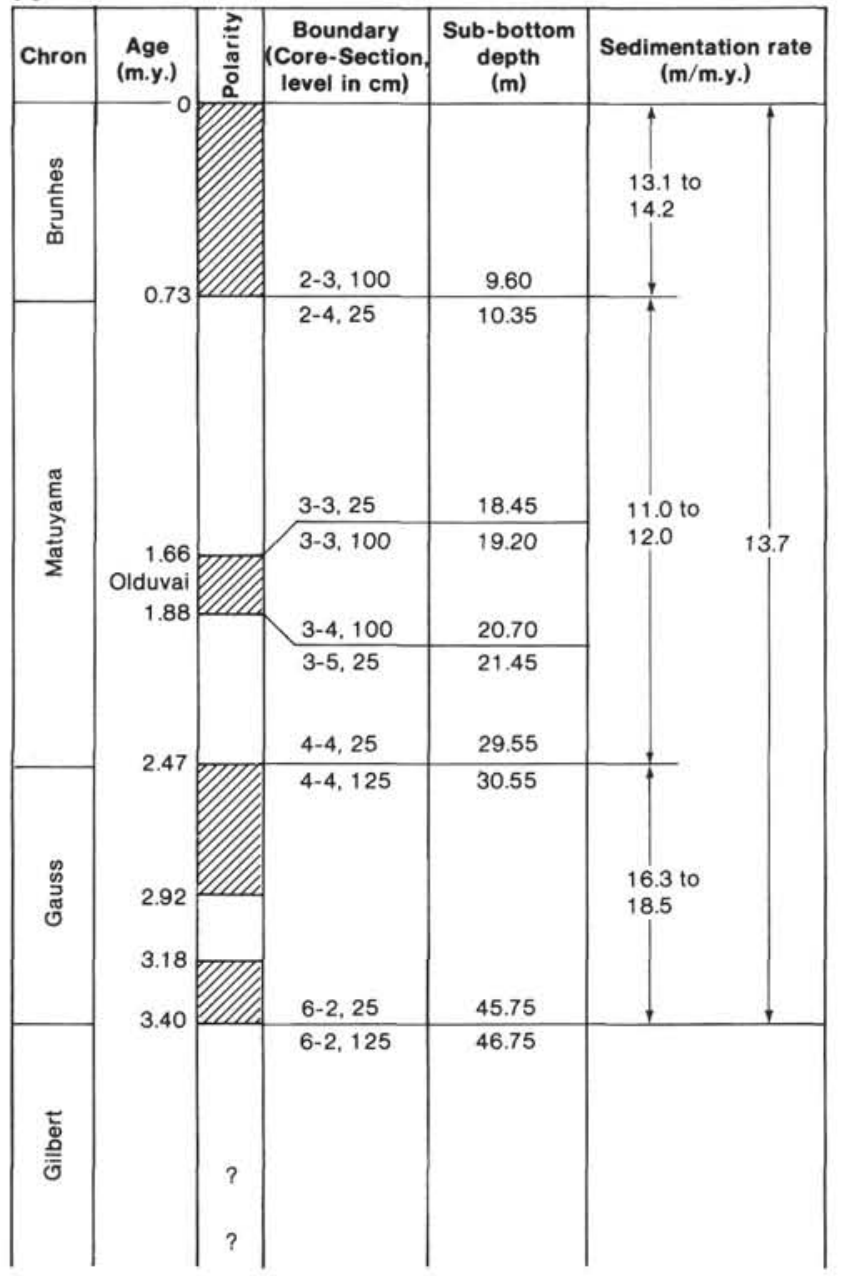

B

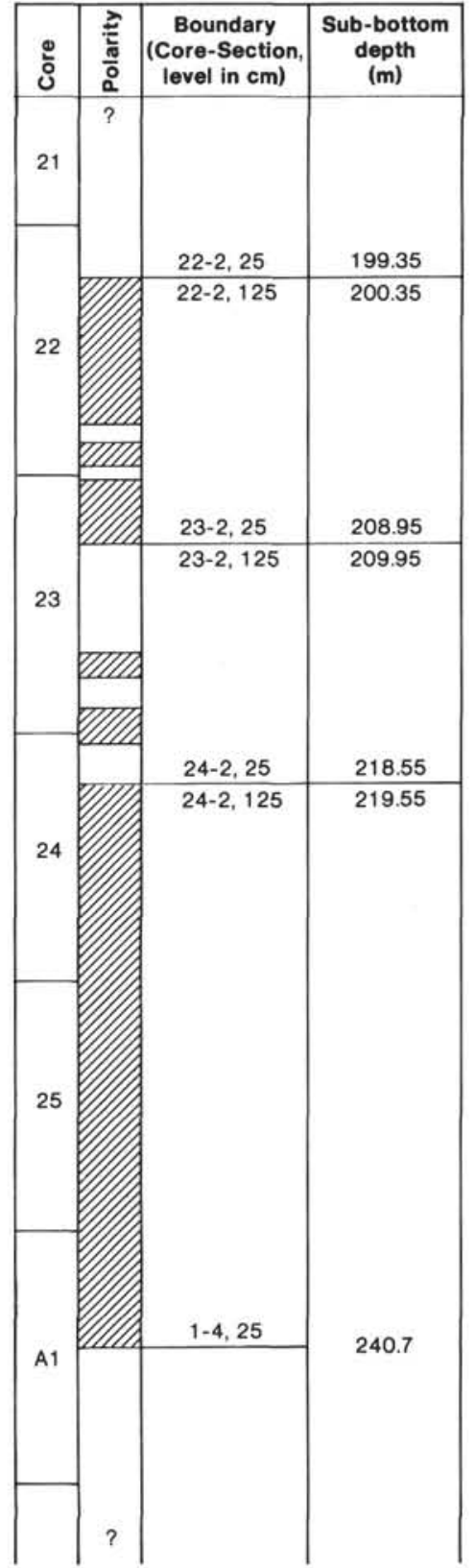

Figure 10. A. Magnetic polarity boundaries for the upper part of Hole 588. B. Polarity zonations at the bottom of Hole 588 and the top of $588 \mathrm{~A}$. Shaded zones are normal polarity.

Neogene but less so in the Oligocene. The foraminiferal and calcareous nannofossil zonal sequences are complete (Fig. 12), suggesting that there are no hiatuses above the upper Oligocene (NP24). A paleomagnetic polarity stratigraphy has been identified down to the upper part of the Gilbert Chron (about 3.5 m.y.).

Two sedimentary units are distinguished (Fig. 12), the upper one divided into three subunits. Subunit IA is a foraminifer-bearing nannofossil size to a nannofossil-bearing foraminiferal ooze in an oxidized and winnowed environment. Subunit IB, comprising much of the sediment column at Site 588 , is largely a foraminifer-bearing nannofossil ooze, distinguished from Subunit IC by its softness. Subunit IC grades from soft ooze at its top to firm ooze at about 150 to $180 \mathrm{~m}$ (Holes 588 and 588B, respectively) to chalk at about 215 to $260 \mathrm{~m}$ (Holes 588 and $588 \mathrm{~B}$, respectively).

At the bottom of Site 588 (Hole 588C) is Unit II which is separated from overlying Unit IC by the regional unconformity that separates middle or late Eocene from late or middle Oligocene sediments. At Site 588 the unconformity separates sediments of middle Eocene (NP1516) from late Oligocene (NP24) age.

The middle Eocene sediments consist of siliceous foraminifer-bearing nannofossil chalks and foraminifer-bearing cherts. Less than $1 \mathrm{~m}$ of Unit II was recovered before the site was terminated. This lithostratigraphic unit is characterized by the presence of siliceous sponge spic- 
ules, diatoms, and diagenetic chert, and coincides with Unit 2 of DSDP Site 208 (Burns, Andrews, et al., 1973).

Textbook examples of microfaults and slickensides occur in three upper lower Miocene cores in a zone where ooze grades into chalks. Surfaces are occasionally mineralized by iron sulfide and possibly rhodochrosite.

There are many thin volcanic ash layers through the Miocene sequence, occurring as singlets, doublets, or triplets and with groups exhibiting quasi-regular perodicities in some intervals. Most are completely undisturbed by bioturbation, which is unusually limited in this site and is an ineffective agent of sediment homogenization. Nevertheless, excellent examples of Zoophycos and Chondrites burrows occur throughout this sequence, as well as relatively sparse larger circular or ovoid $(0.5-3.0 \mathrm{~cm}$ across) burrow sections and mottles.

Iron sulfides are persistent through the section and have a close association with volcanic ash layers. Drilling terminated in middle Eocene siliceous-rich chalks and cherts.

The uncorrected rates of sedimentation are as follows: lower Oligocene-early Miocene, $20.6 \mathrm{~m} / \mathrm{m}$.y.; early Miocene, 14.4; middle Miocene-early Pliocene, 17.4, lower Pliocene, 29.5; Quaternary, $12.2 \mathrm{~m} / \mathrm{m}$.y.

In general, the diversity of the benthic faunas and their abundance decrease down the section. Changes in the benthic foraminiferal assemblages provide useful information about changes in intermediate water masses during the Neogene. Elimination of typical Eocene-Oligocene benthic forms occurred in the late early Miocene. During the early late Miocene there was an influx of several species of deeper-water origin. During the Pliocene there was an upward disappearance of several important benthic species and a large number of species disappeared during the late Pliocene, at about $3 \mathrm{~m}$.y.

\section{REFERENCES}

Boyce, R. E., 1976. Definitions and laboratory techniques of compressional sound velocity parameters and wet-water content, wetbulk density, and porosity parameters by gravimetric and gammaray attenuation techniques. In Schlanger, S. O., Jackson, E. D., et al., Init. Repts. DSDP, 33: Washington (U.S. Govt. Printing Office), 931-958.

1977. Deep Sea Drilling Project procedures for shear strength measurement of clayey sediment using modified Wykeham Farrance laboratory vane apparatus. In Barker, P. F., Dalziel, I. W. D., et al., Init. Repts. DSDP, 36: Washington (U.S. Govt. Printing Office), 1059-1068.

Burns, R. E., Andrews, J. E., et al., 1973. Init. Repts. DSDP, 21: Washington (U.S. Govt. Printing Office).

Kennett, J. P., 1973. Middle and late Cenozoic planktonic foraminiferal biostratigraphy of the southwest Pacific-DSDP Leg 21. In Burns, R. E., Andrews, J.E., et al., Init. Repts. DSDP, 21: Washington (U.S. Govt. Printing Office), 575-640.

Mammerickx, J. L., Chase, T. E., Smith, S. M., and Taylor, I. L., 1974. Bathymetry of the South Pacific. IMR Technical Reports, Scripps Institution of Oceanography, La Jolla, California.

Martini, E., 1981. Oligocene to recent calcareous nannoplankton from the Philippine Sea, Deep Sea Drilling Project Leg 59. In Kroenke, L., Scott, R., et al. (Eds.), Init. Repts. DSDP, 59: Washington (U.S. Govt. Printing Office), 547-565.

Sclater, J. G., Meinke, L., Bennett, A., and Murphy, C., in press. The depth of the ocean through the Neogene. In Kennett, J. P. (Ed.), The Miocene Ocean: Paleoceanography and Biogeography. Geol. Soc. Am. Mem. 163.

Srinivasan, M. S., and Kennett, J. P., 1981a. A review of Neogene planktonic foraminiferal biostratigraphy: Applications in the equatorial and South Pacific. In Warme, J. E., Douglas, R. G., Winterer, E. L. (Eds.), The Deep Sea Drilling Project: A Decade of Progress. Soc. Econ. Paleont. Mineral., Spec. Pub., 32:395-432. 1981b. Neogene planktonic foraminiferal biostratigraphy and evolution: equatorial to subantarctic, South Pacific. Mar. Micropaleontol., 6:499-533.

1983. The Oligocene/Miocene boundary in the South Pacific. Geol. Soc. Am. Bull., 94:798-812.

Willcox, J. B., Symonds, P. A., Hinz, K., and Bennett, D., 1980. Lord Howe Rise, Tasman Sea-preliminary geophysical results and petroleum prospects. B.M.R. J. Aust. Geol. Geophys., 5:225-236. 

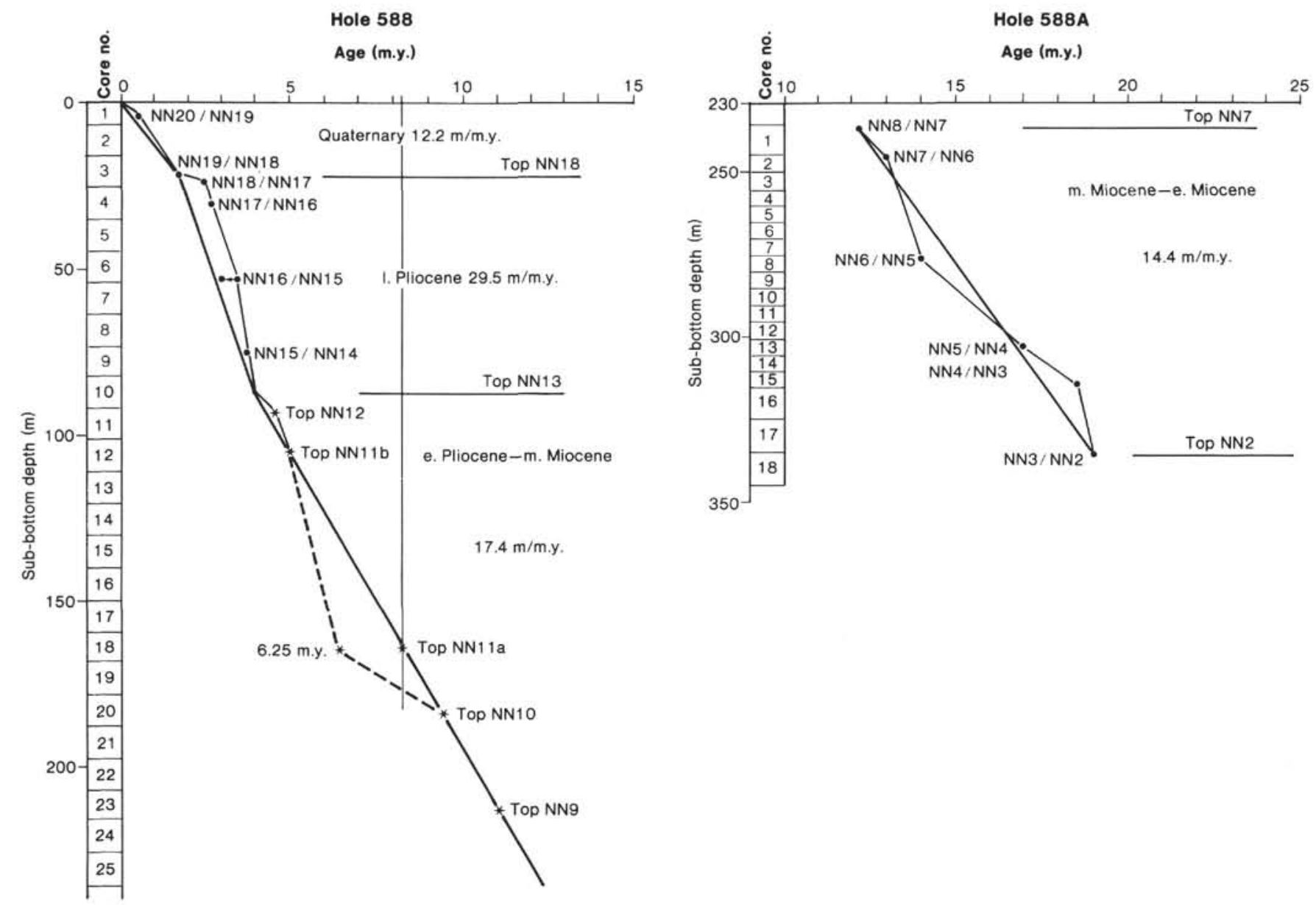

Figure 11. Sedimentation rates at Site 588. 

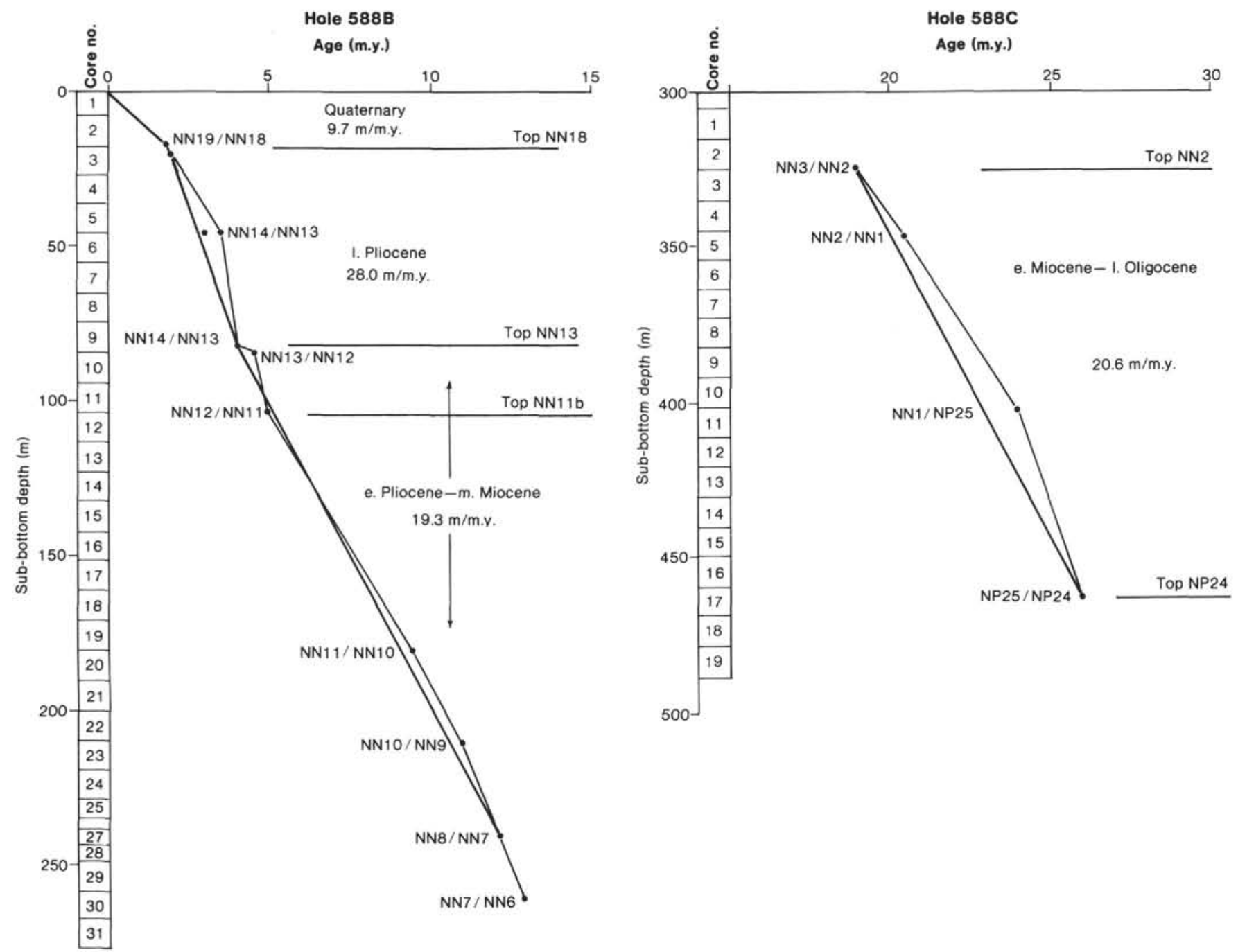

Figure 11. (Continued). 


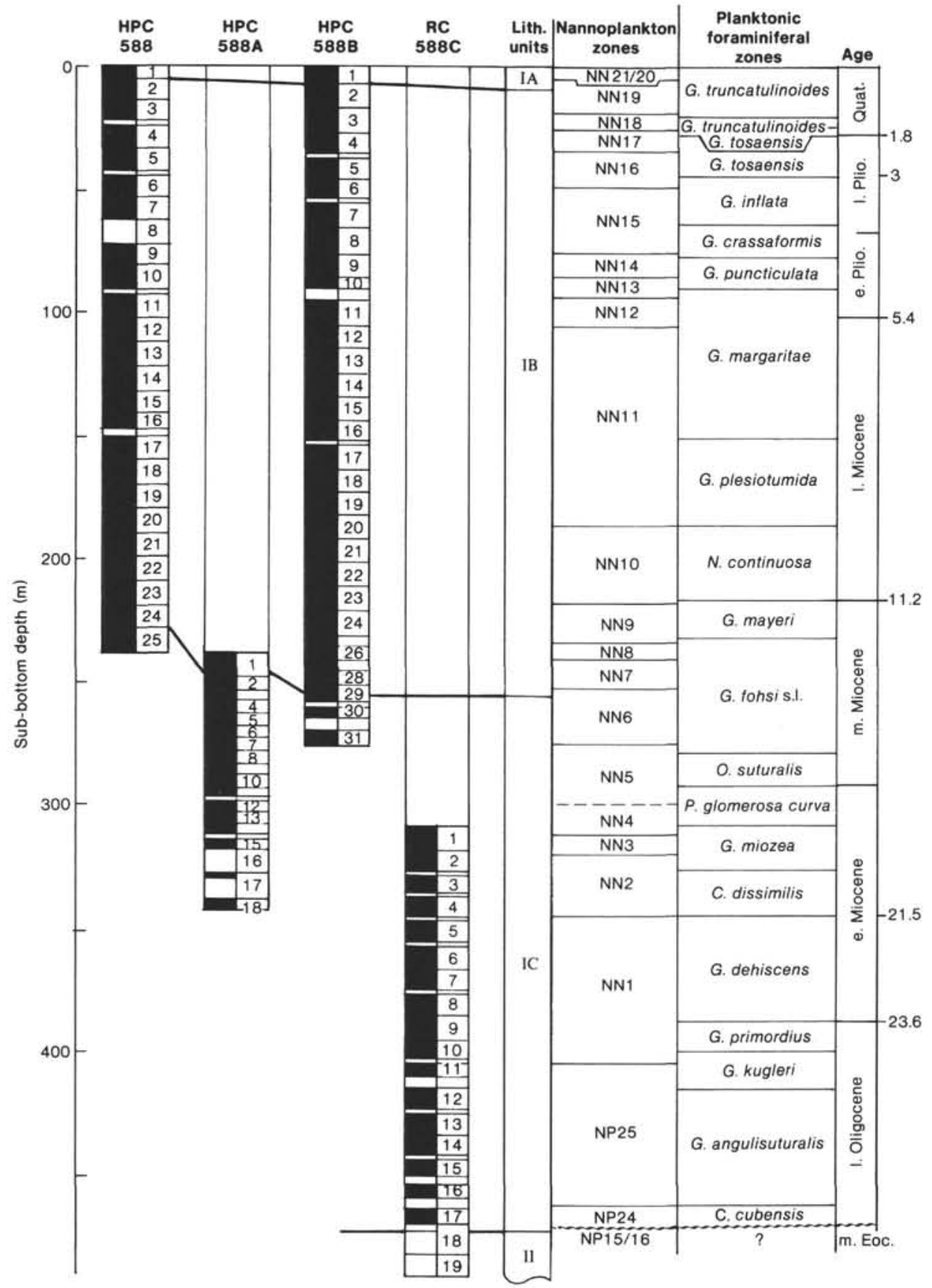

Mass accumulation rates $\left(g / \mathrm{cm}^{2}\right.$ per $\left.m . y.\right)$

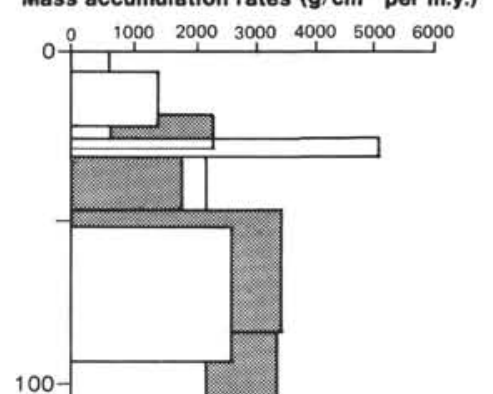

Figure 12. Summary biostratigraphy, lithology, and mass accumulation rates at Site 588. 

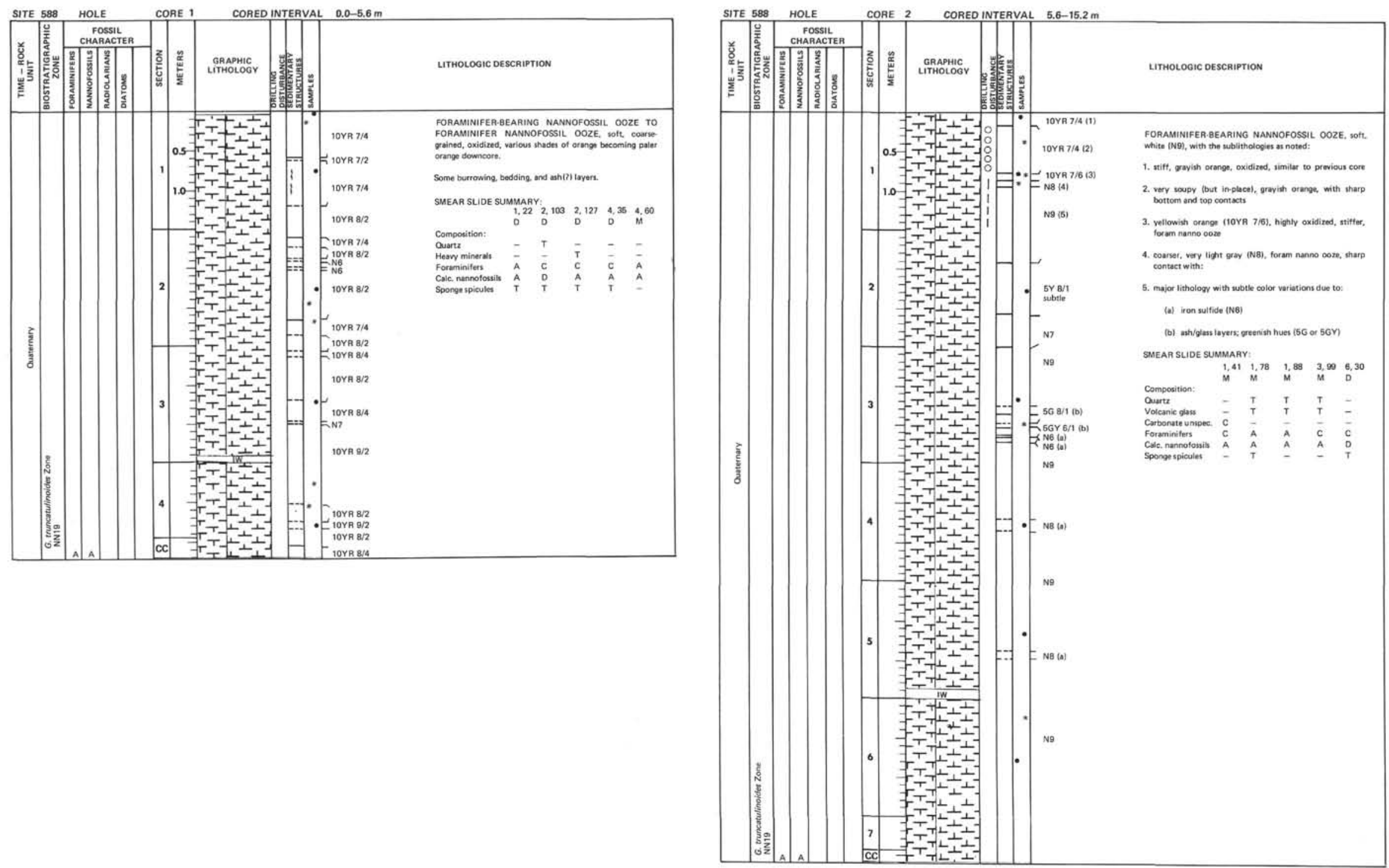

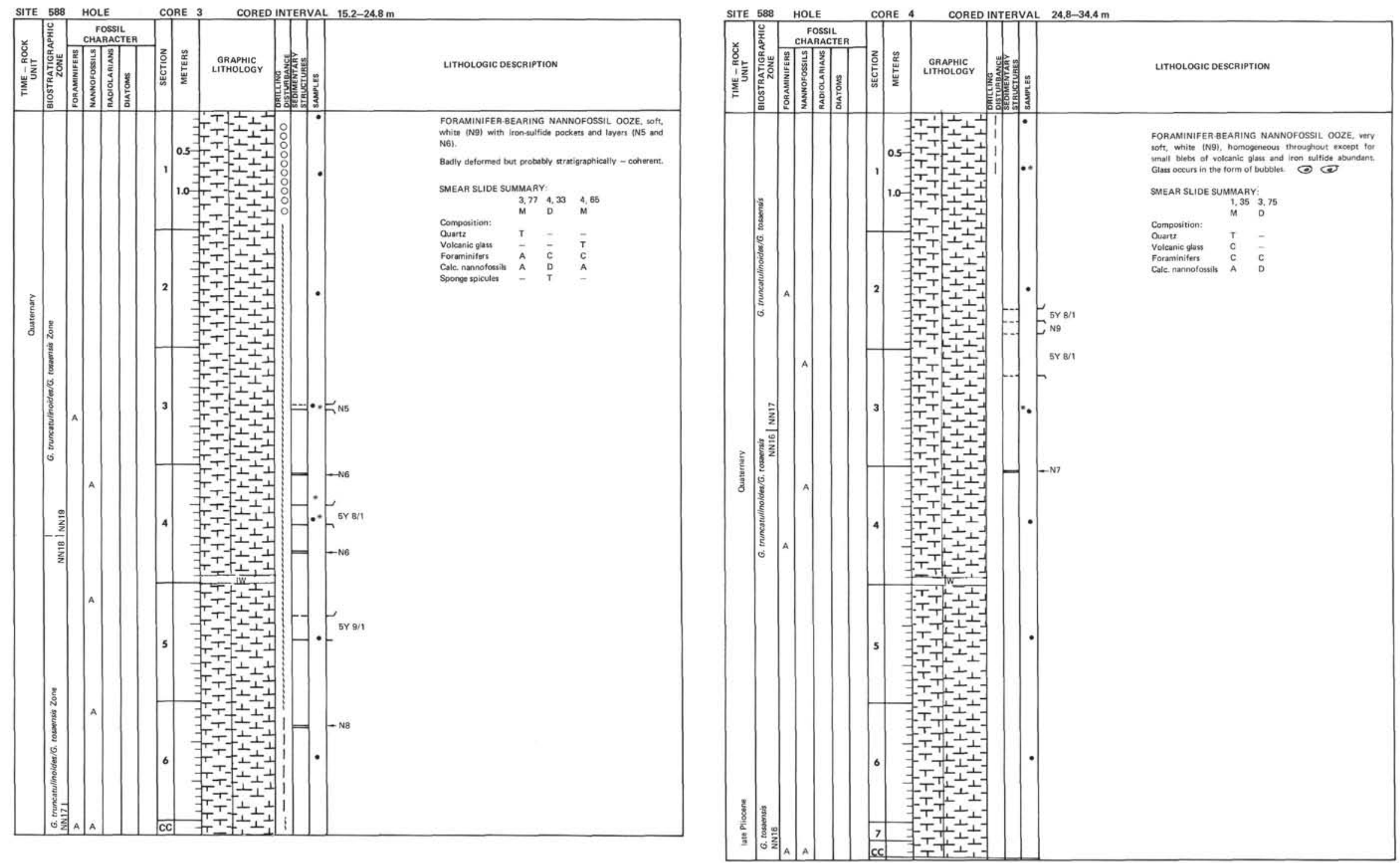

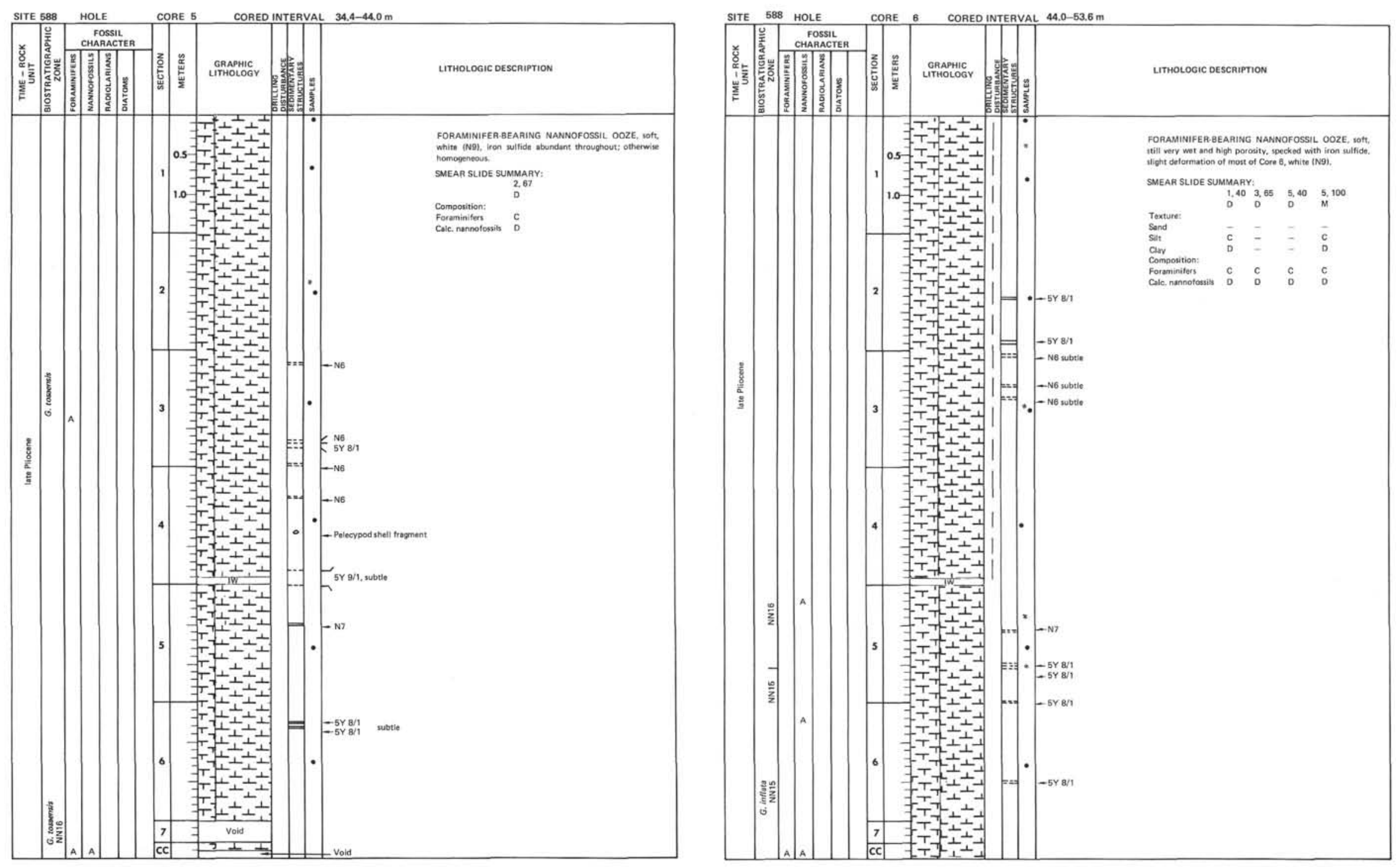

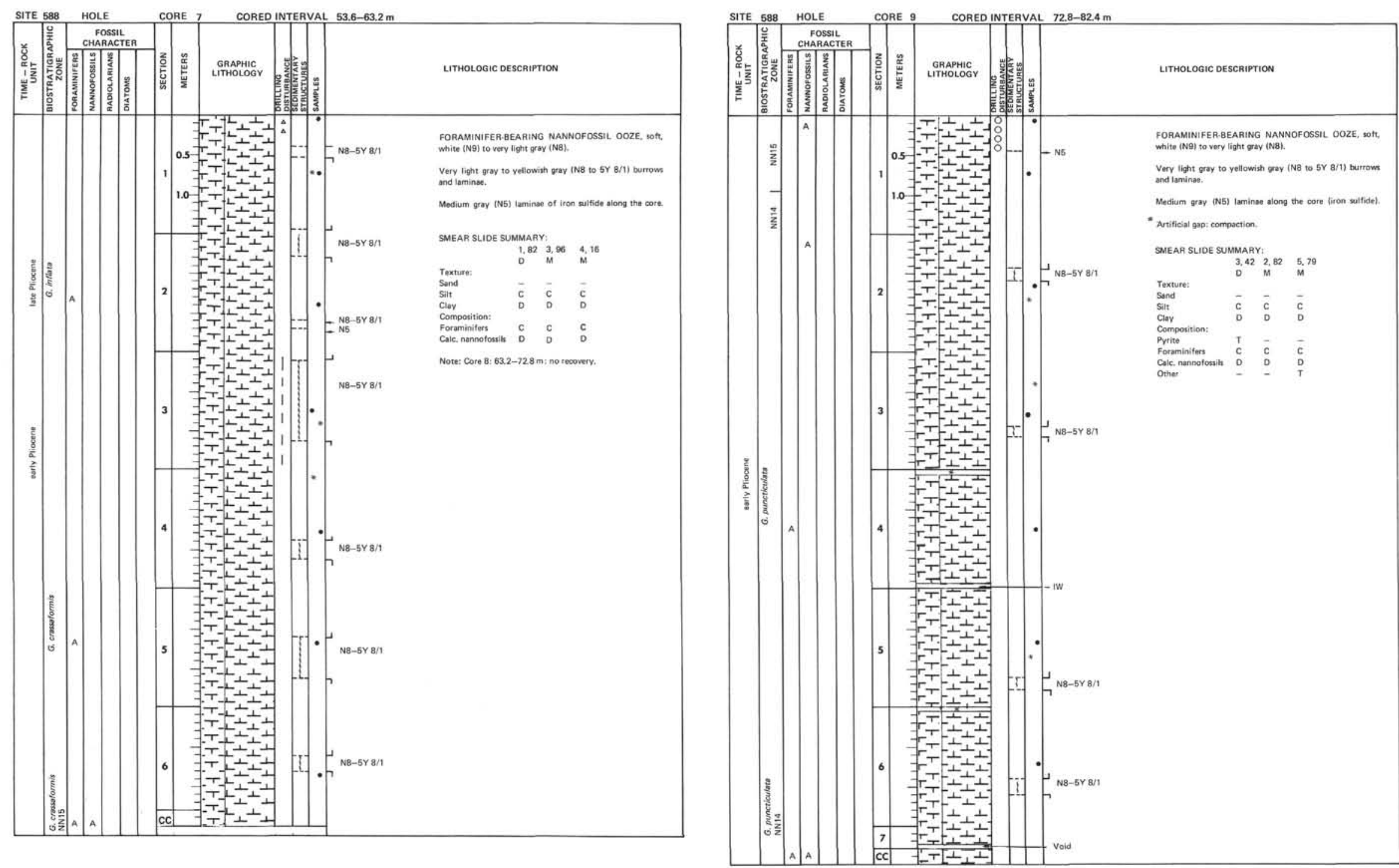

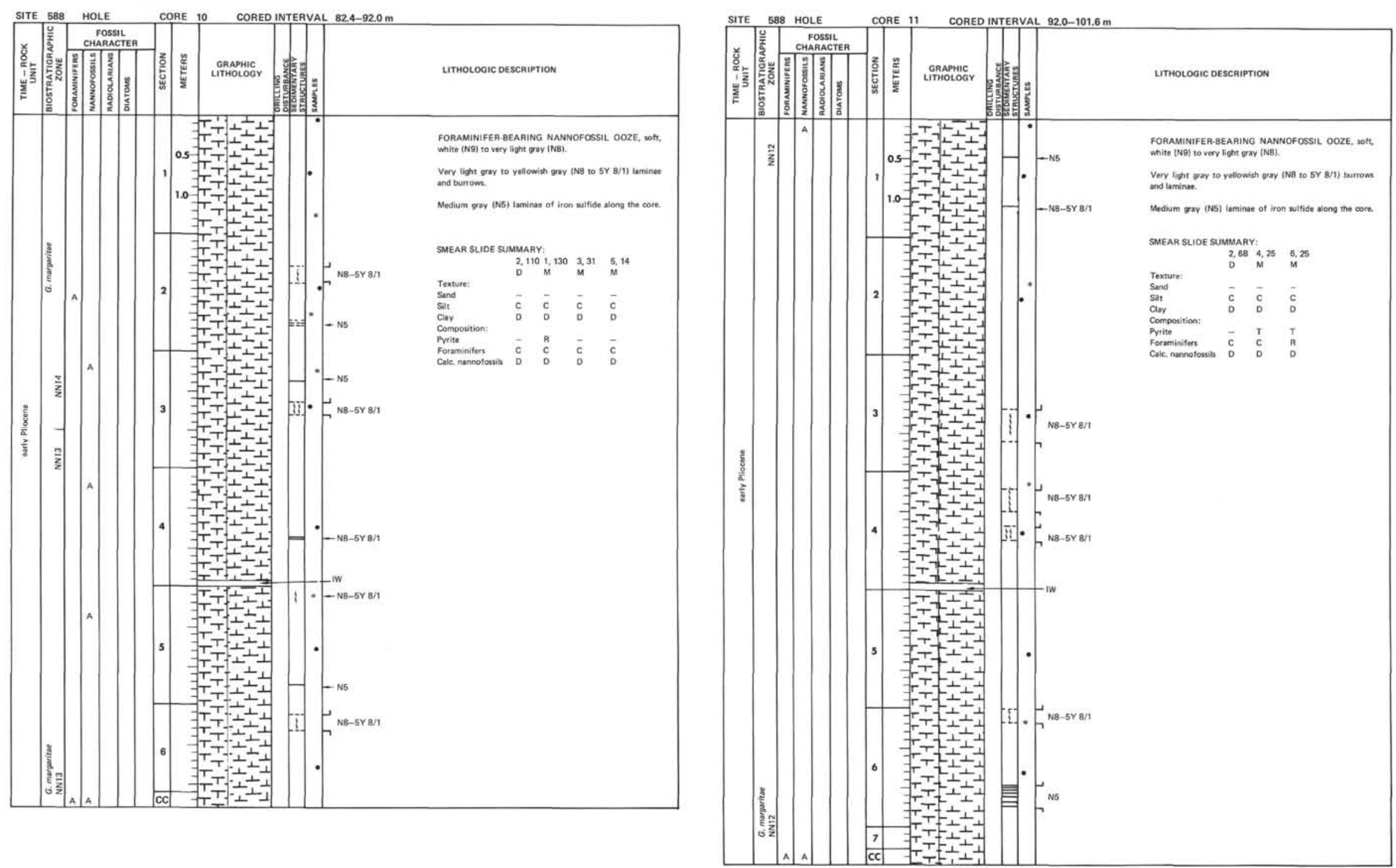

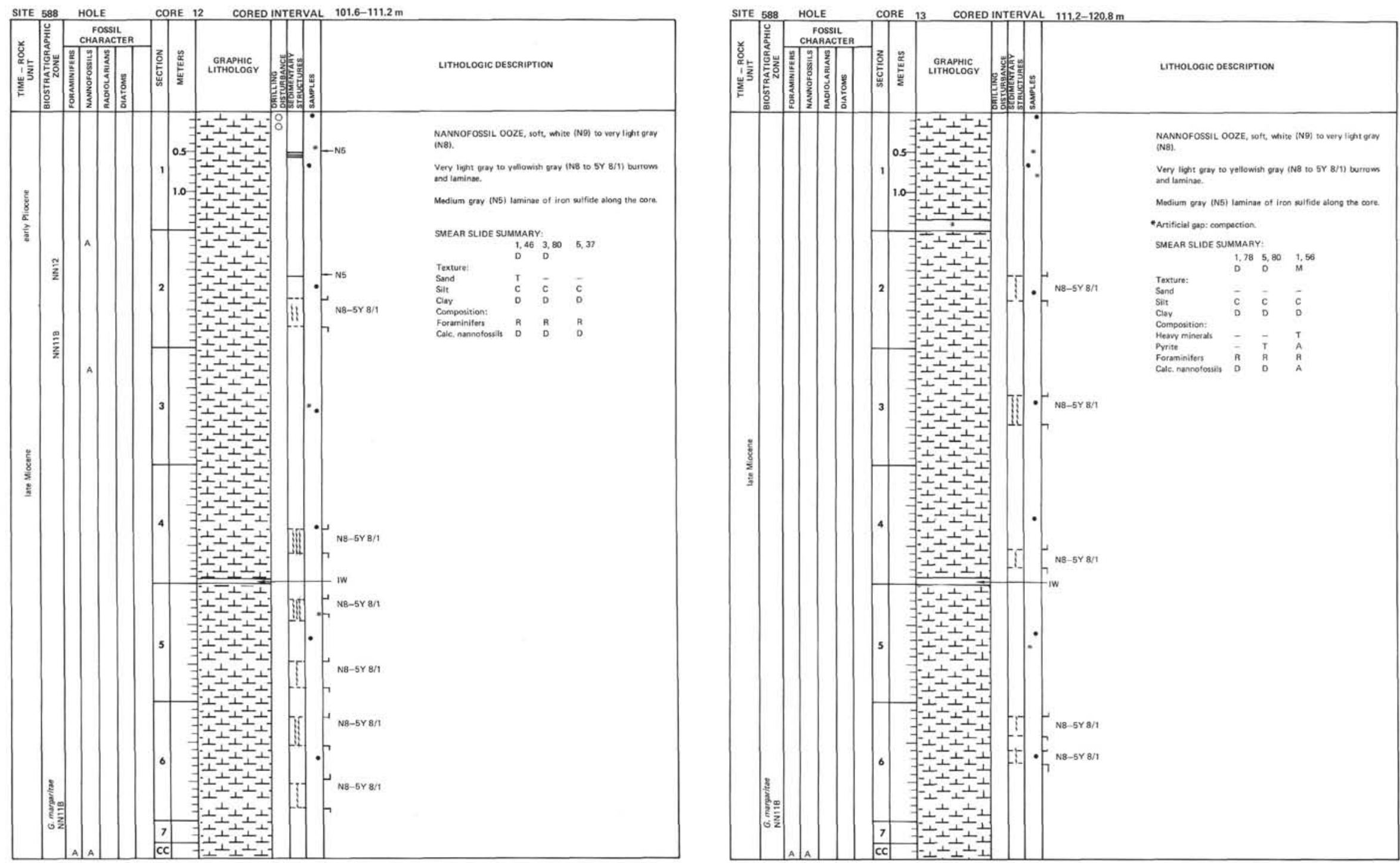

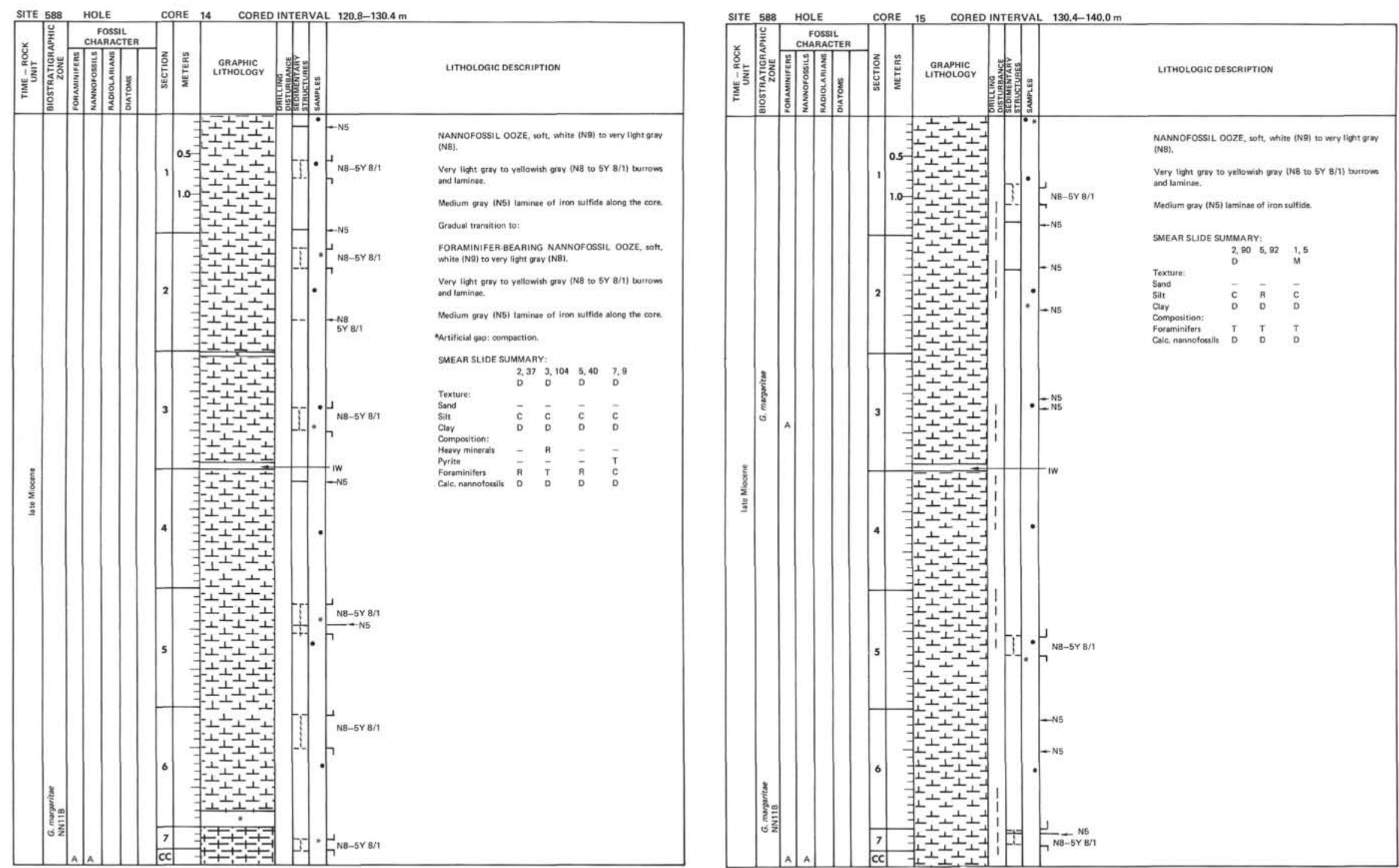

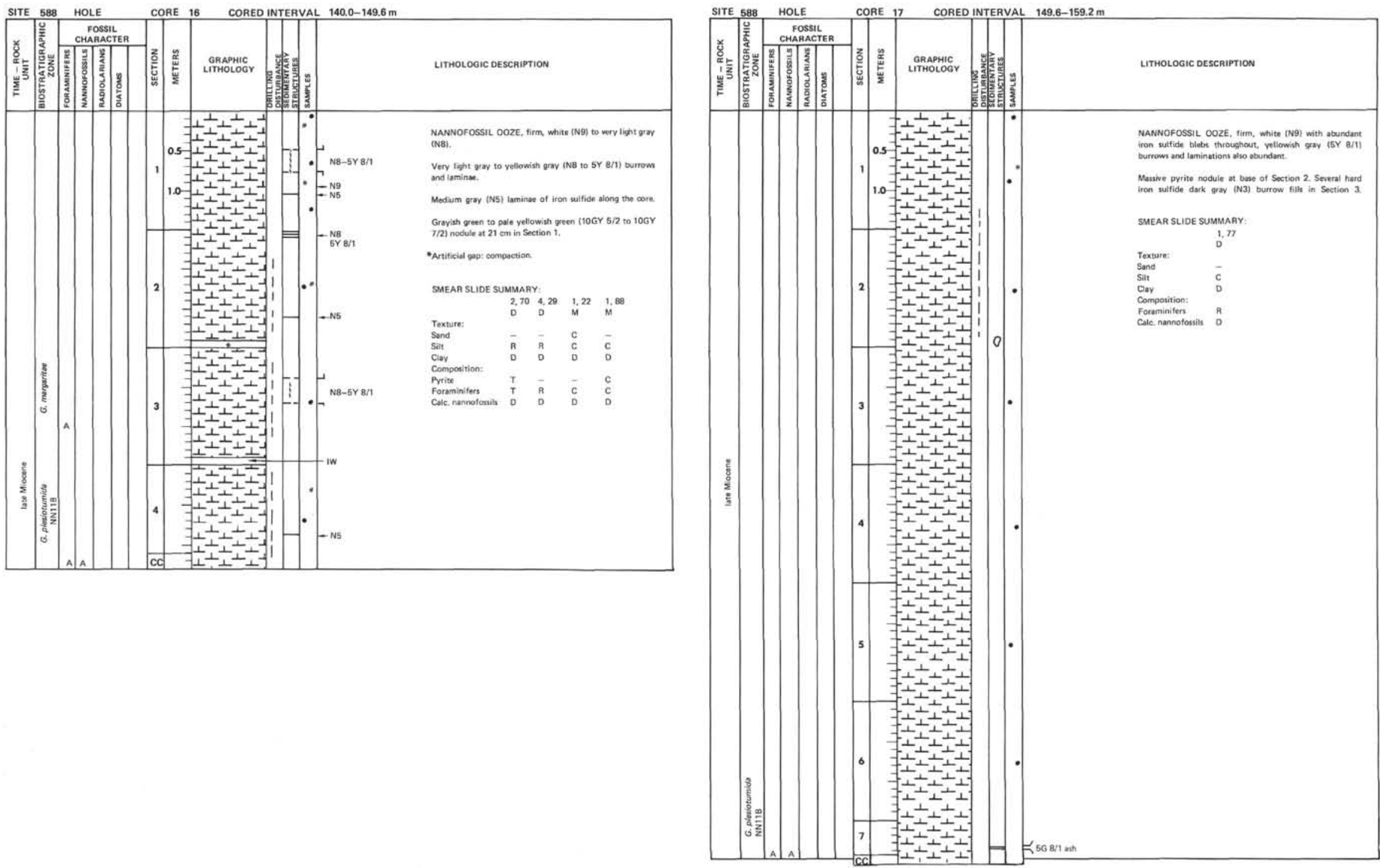

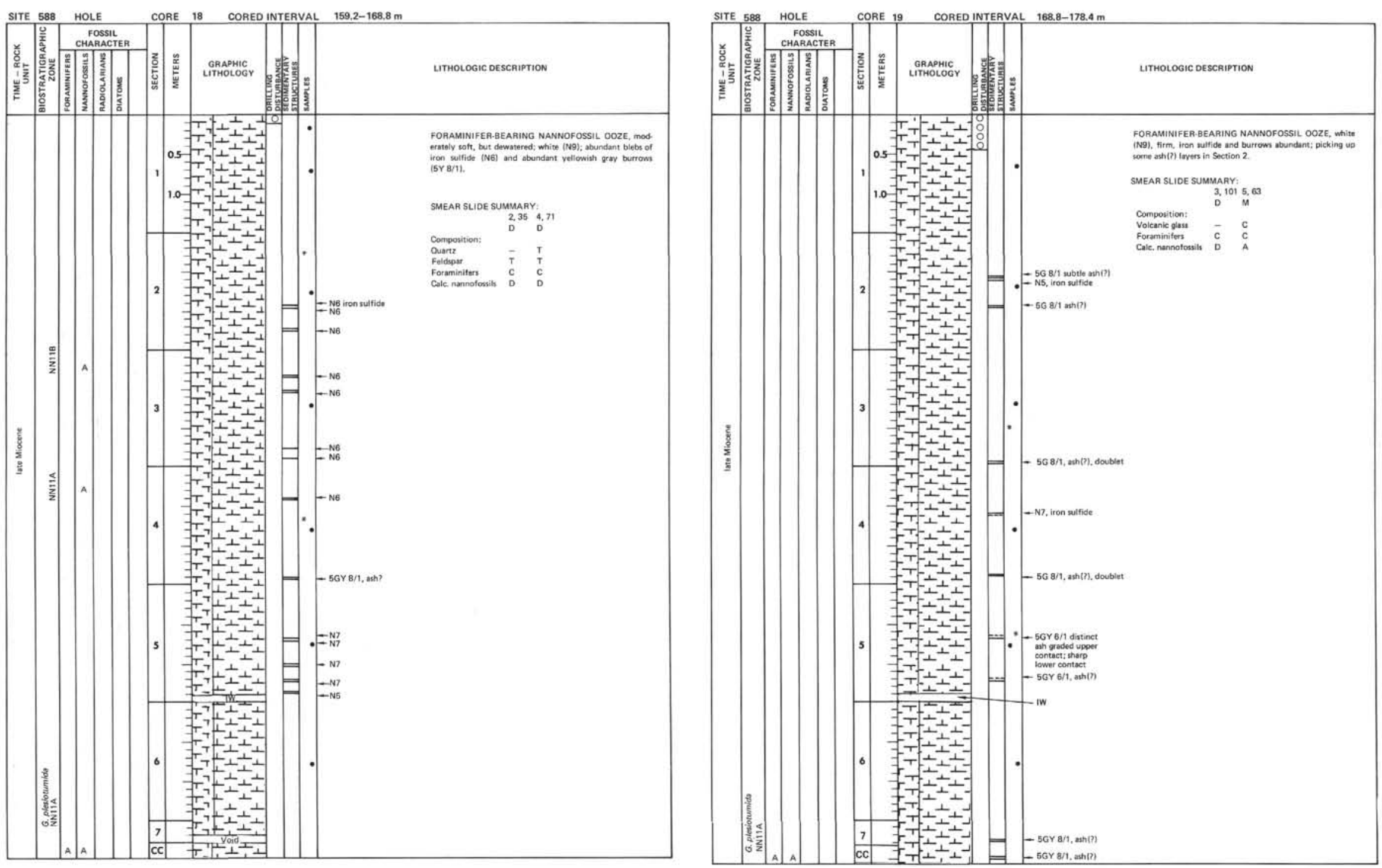

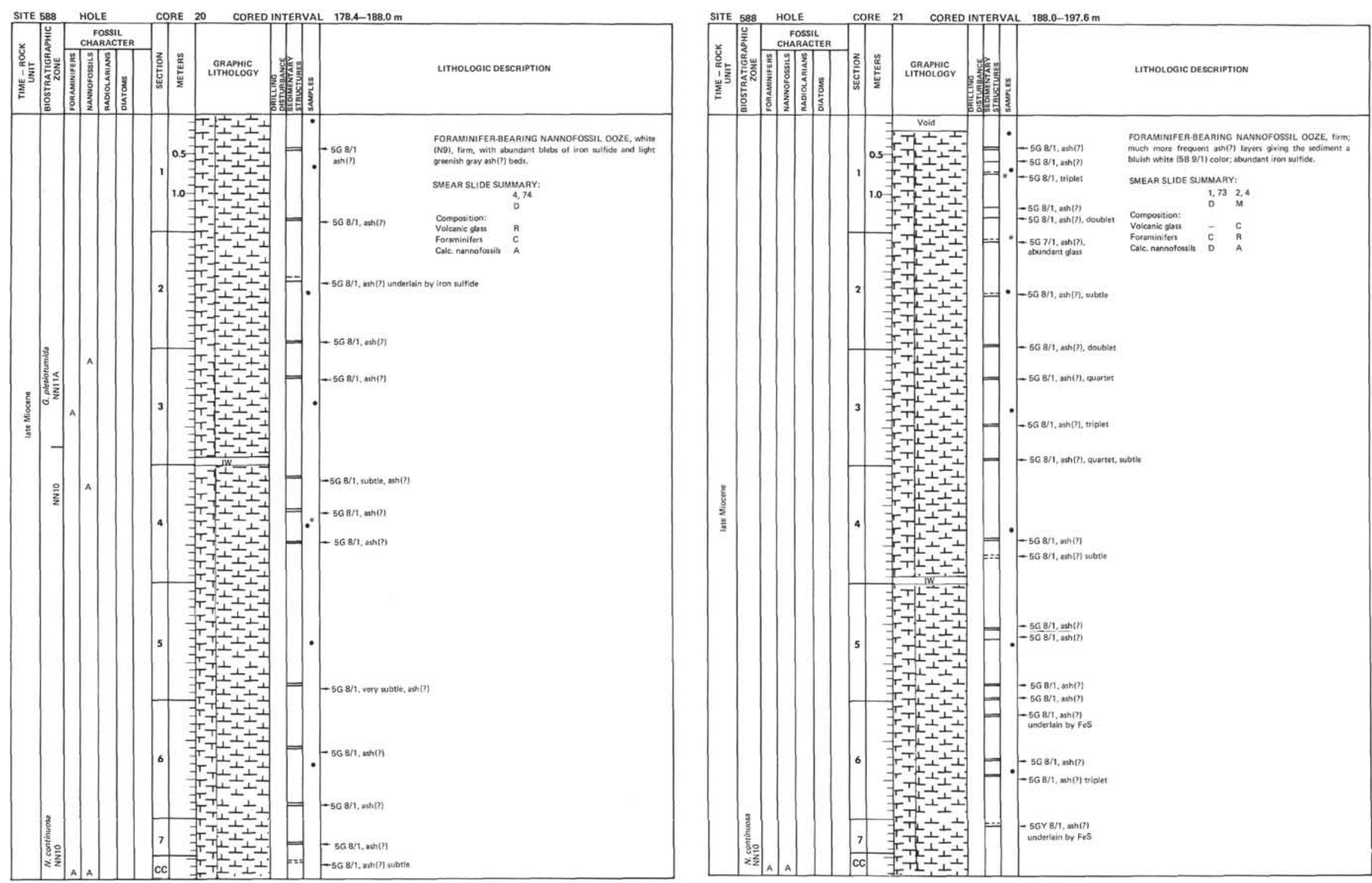

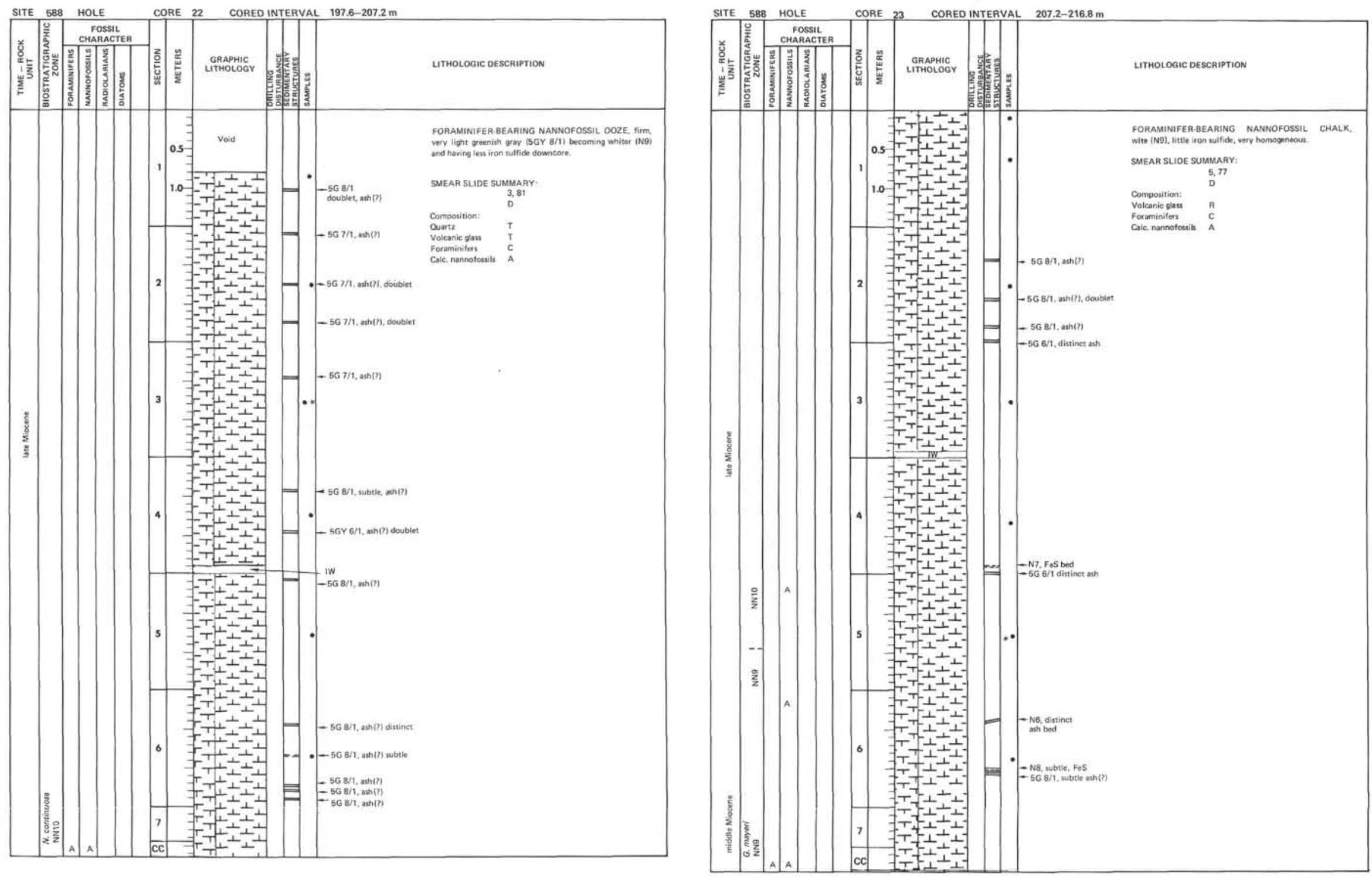

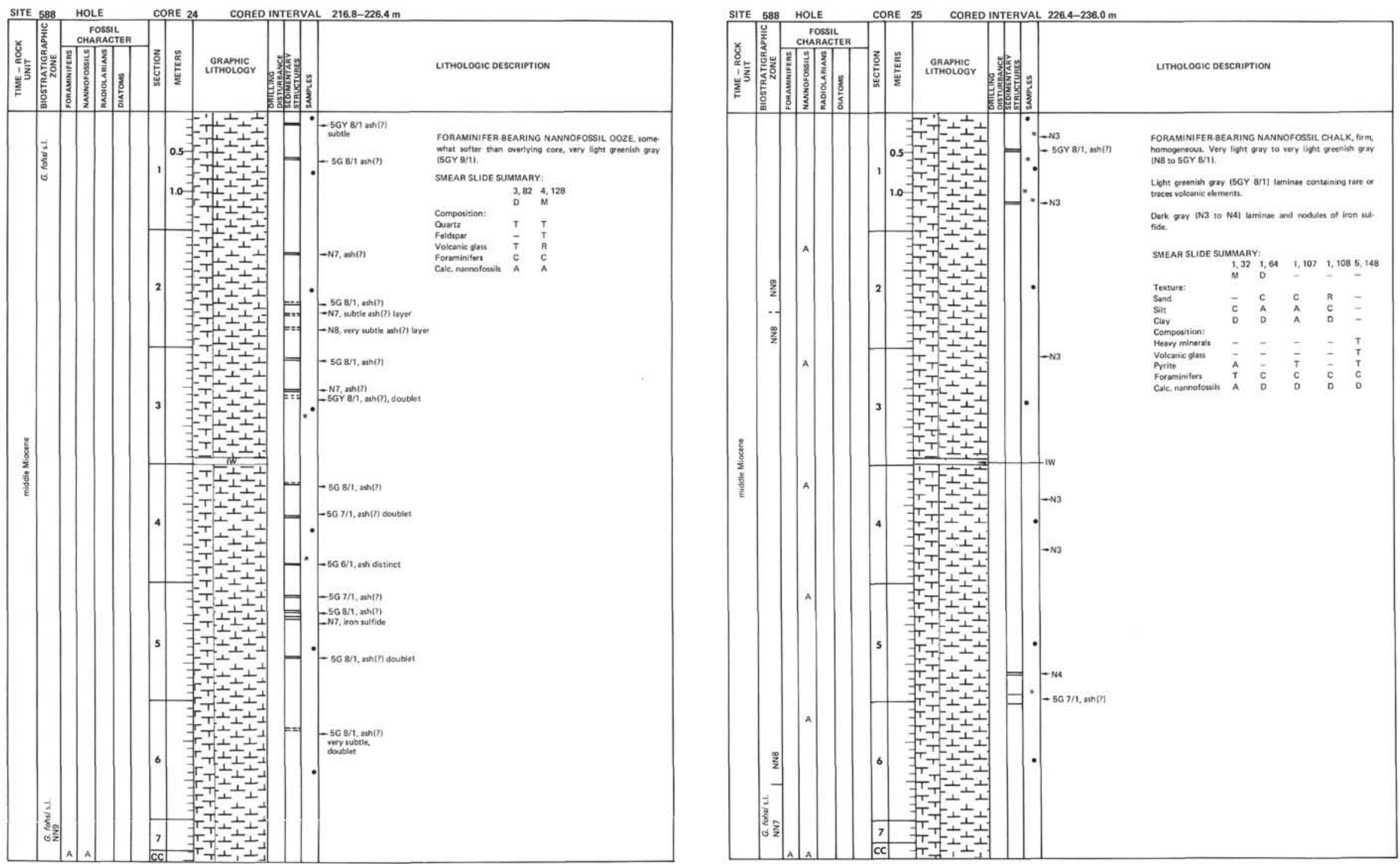


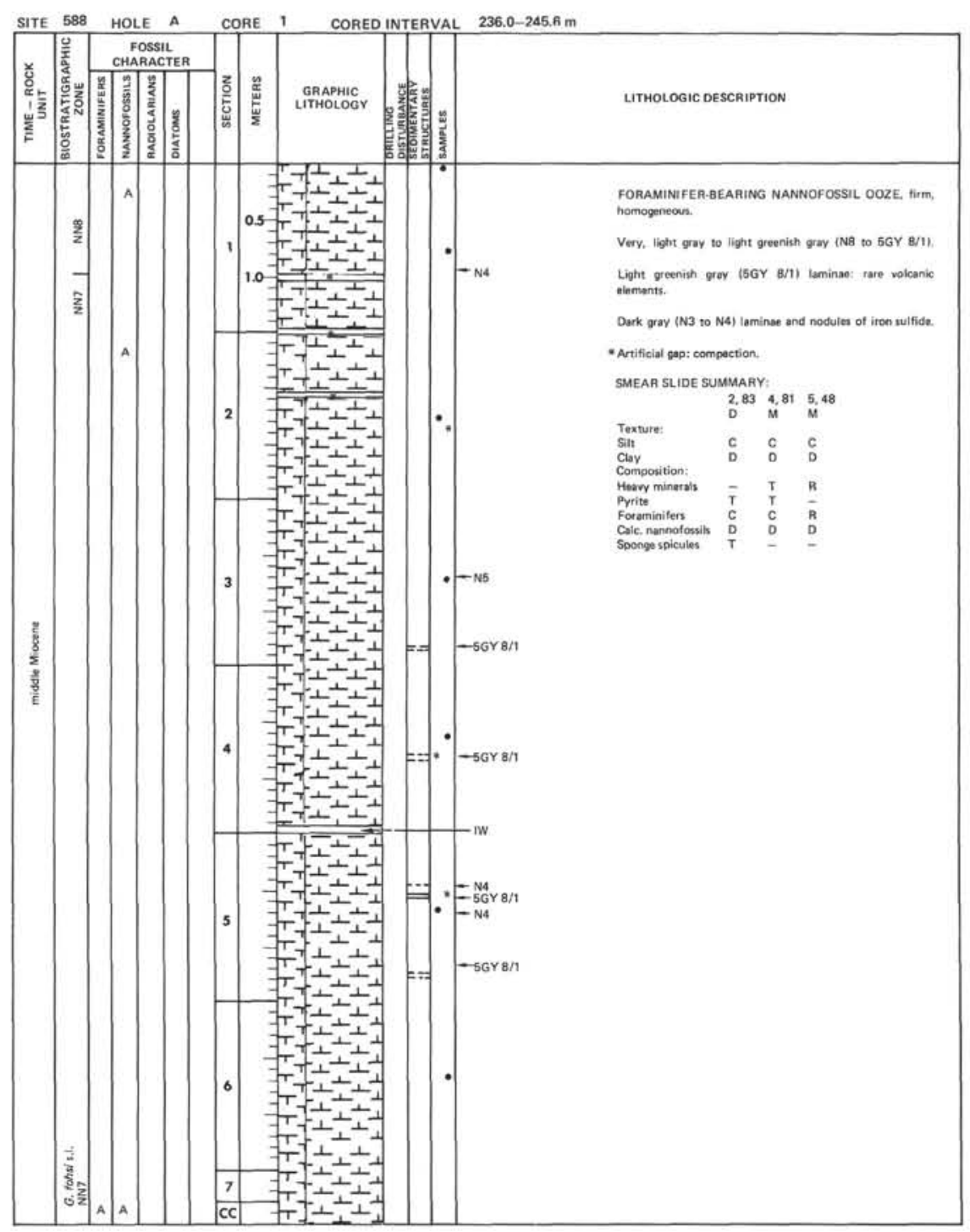

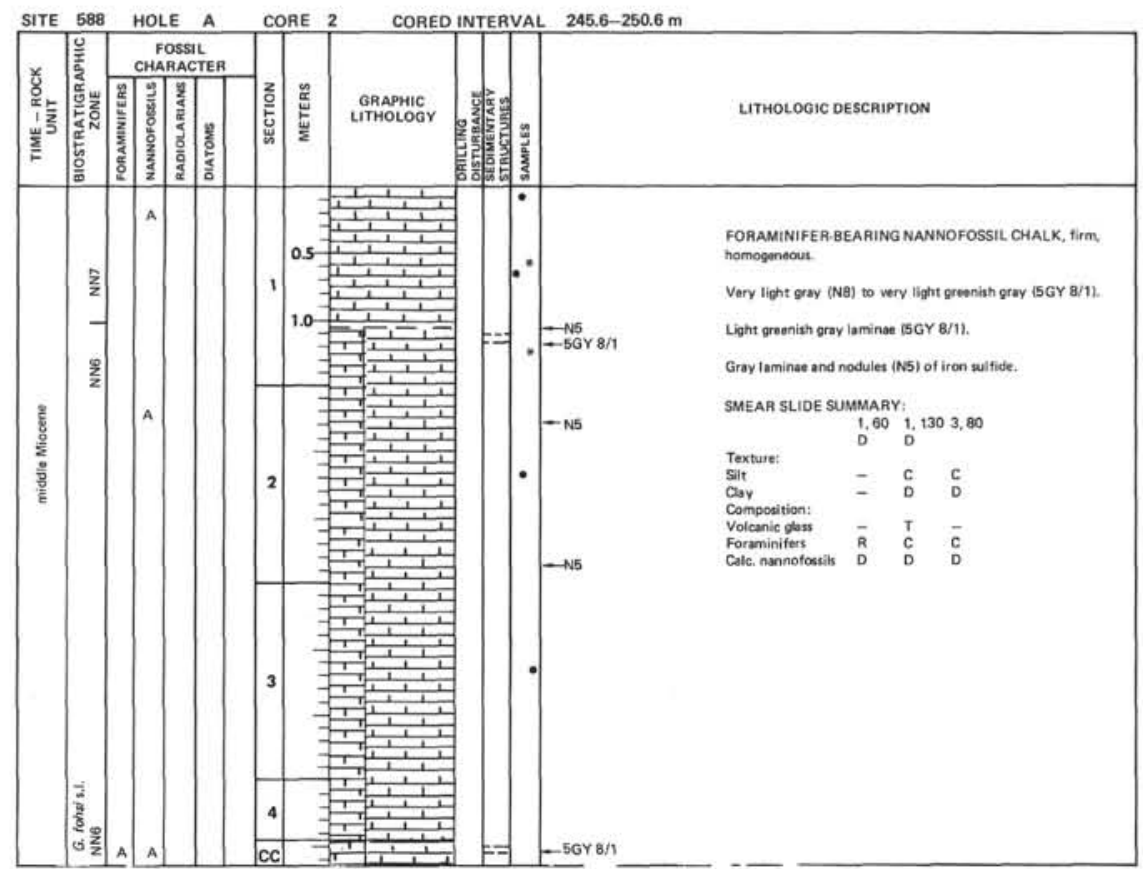

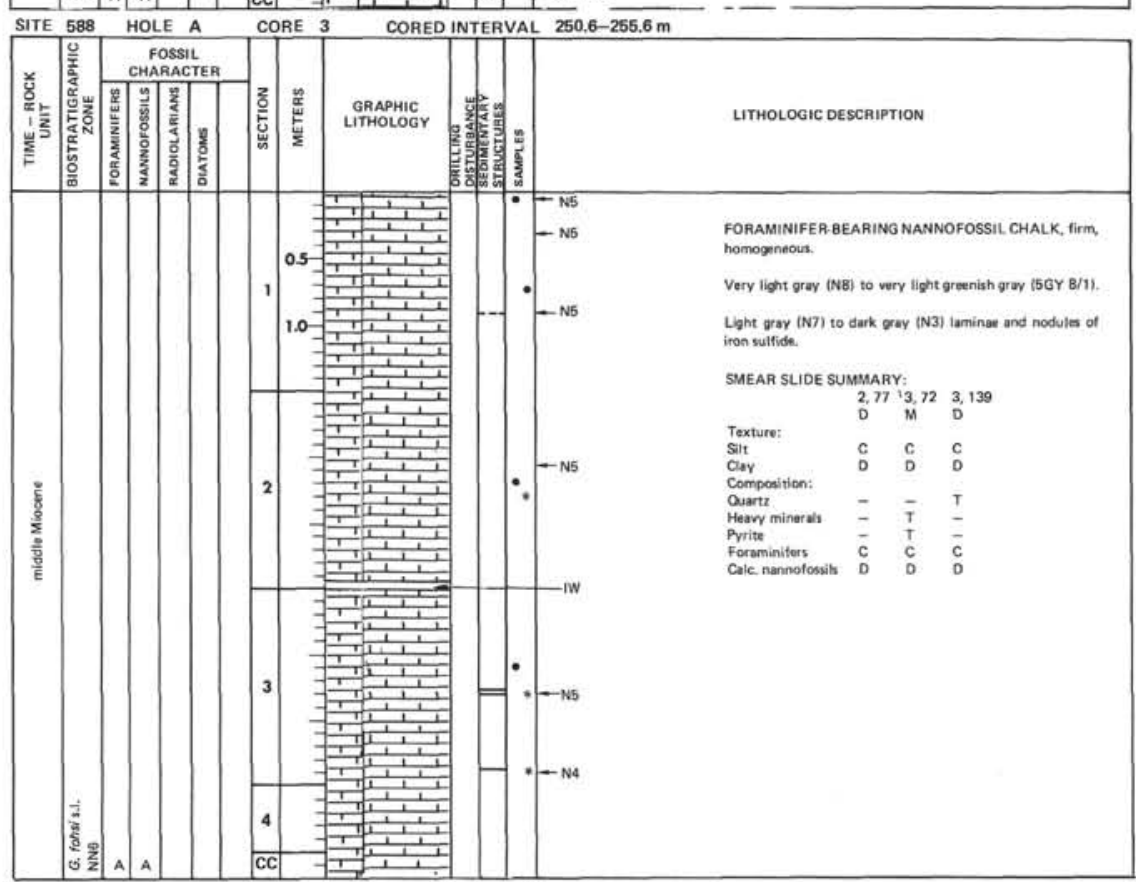



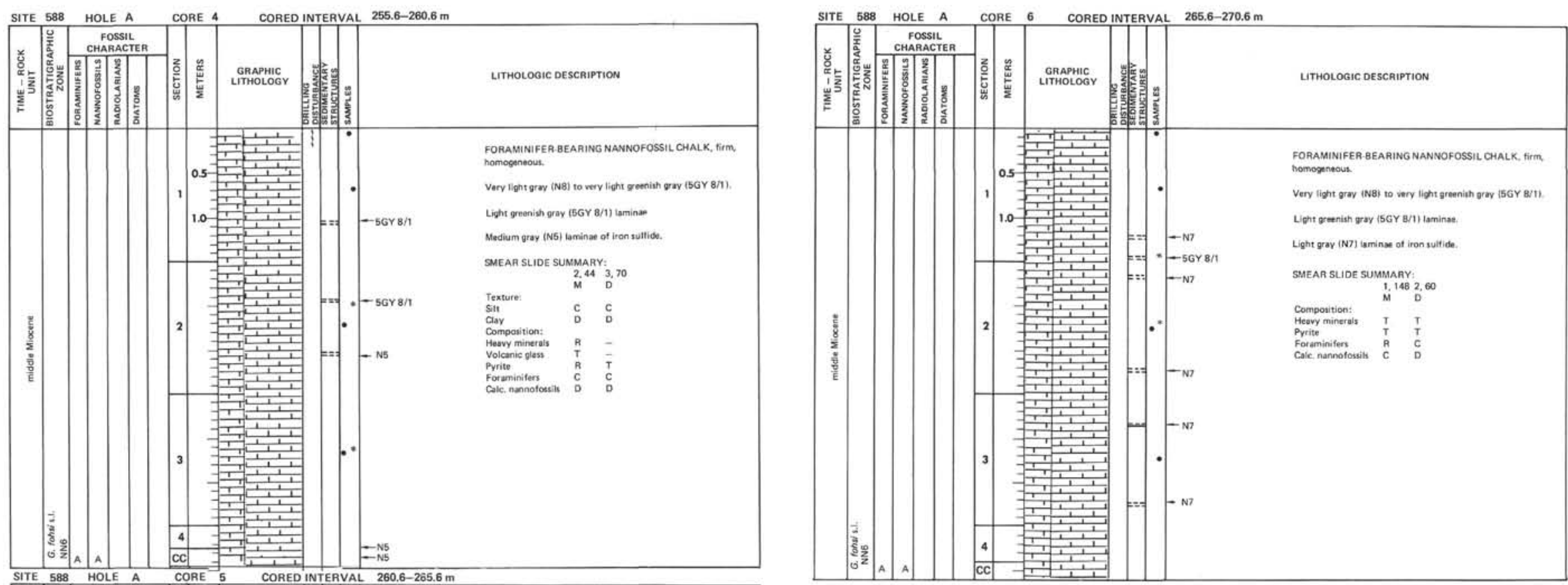

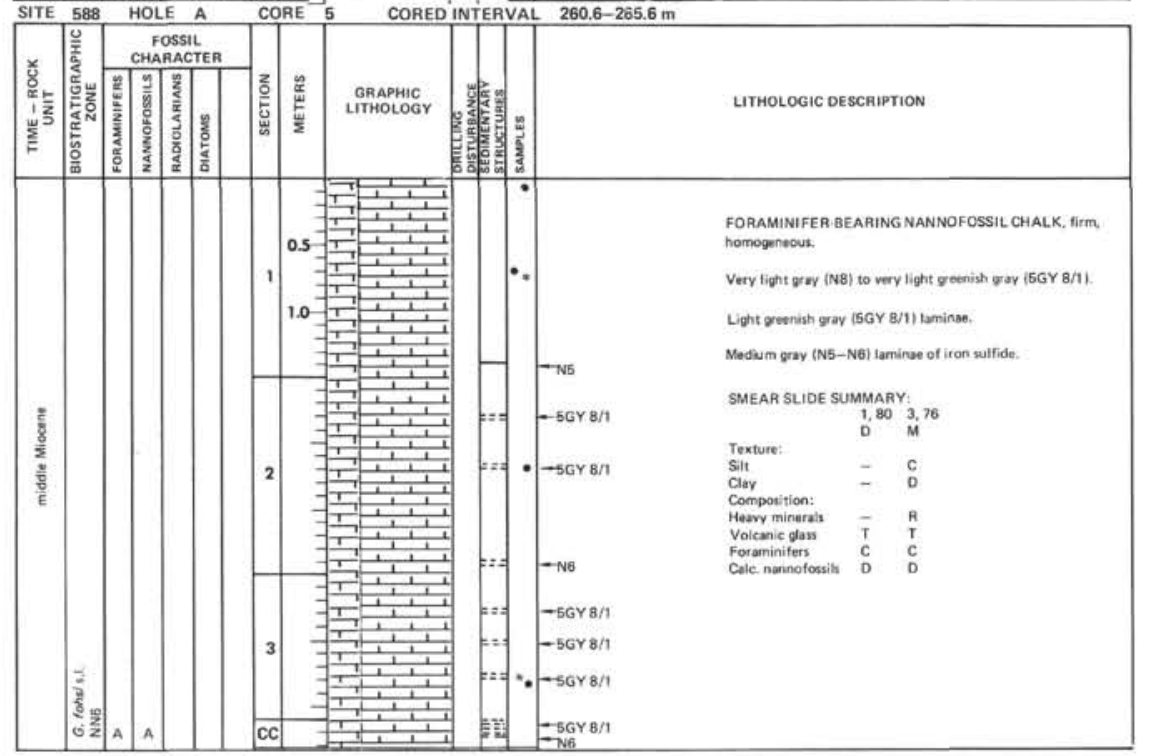

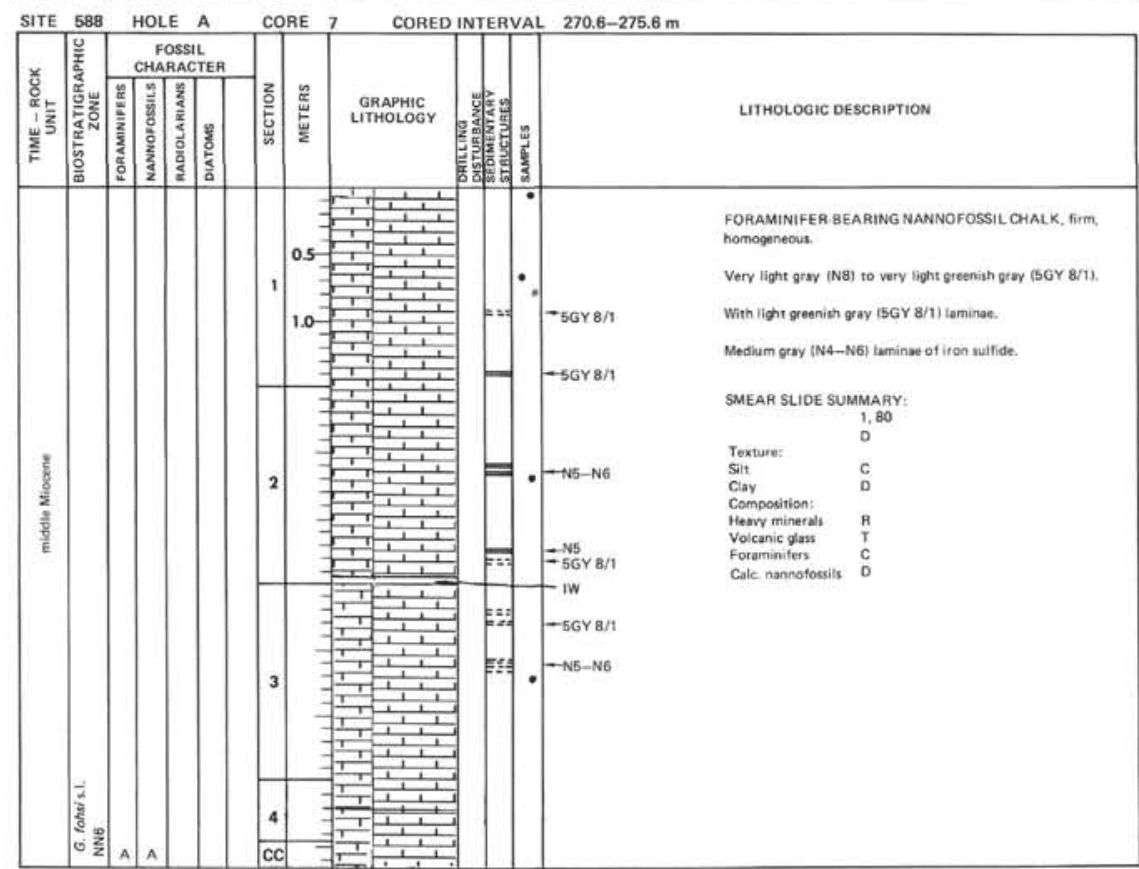



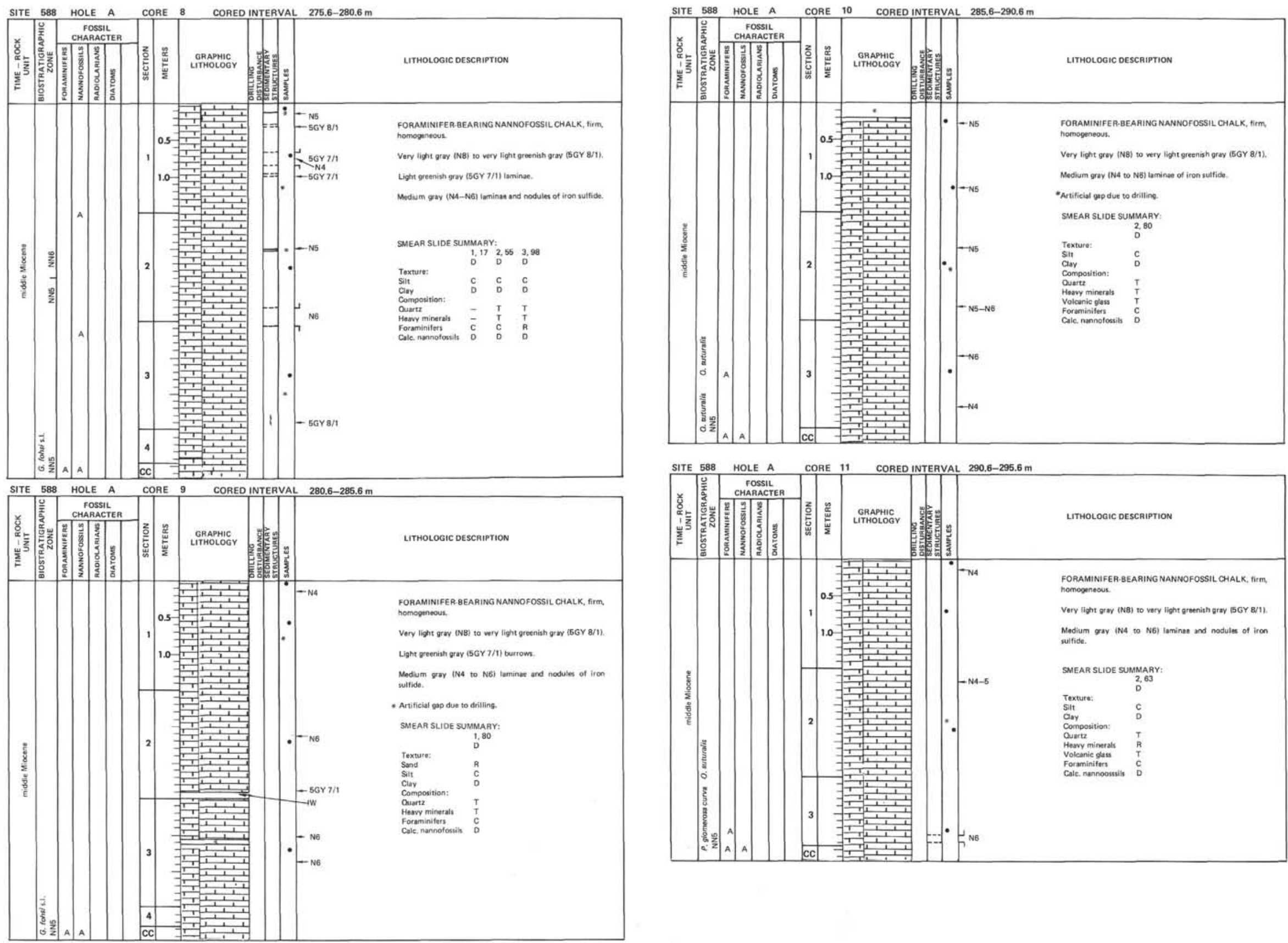

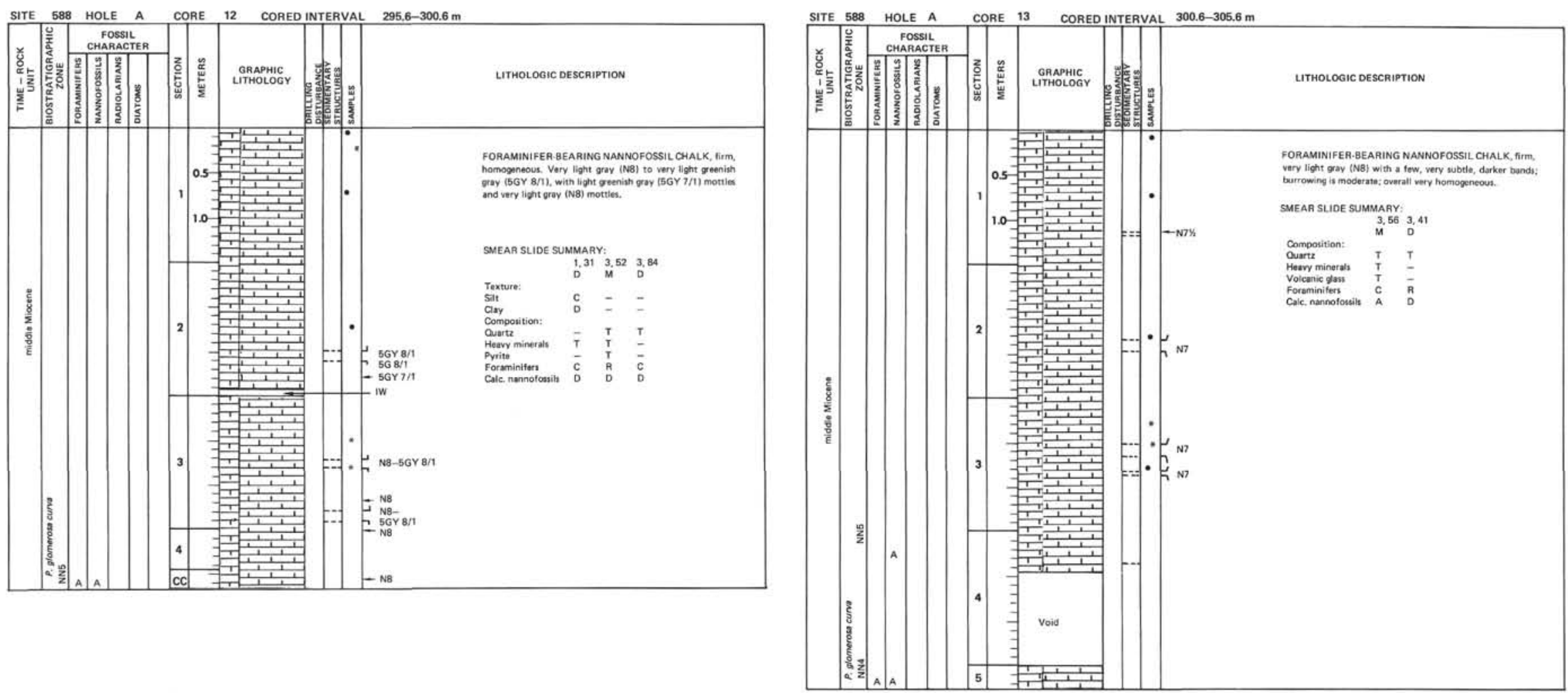

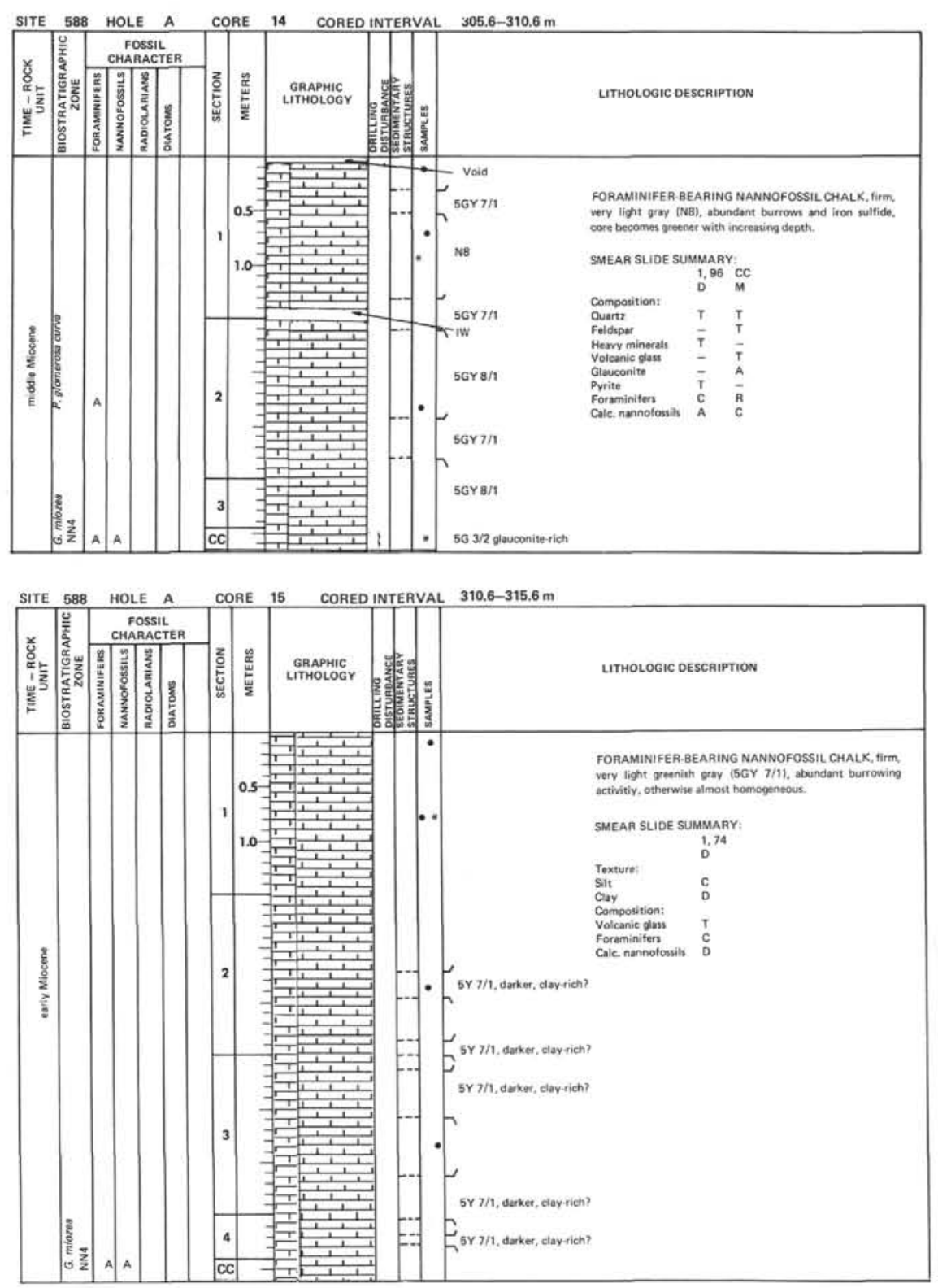

SITE 588 HOLE A CORE 16 CORED INTERVAL $315.6-325.2 \mathrm{~m}$

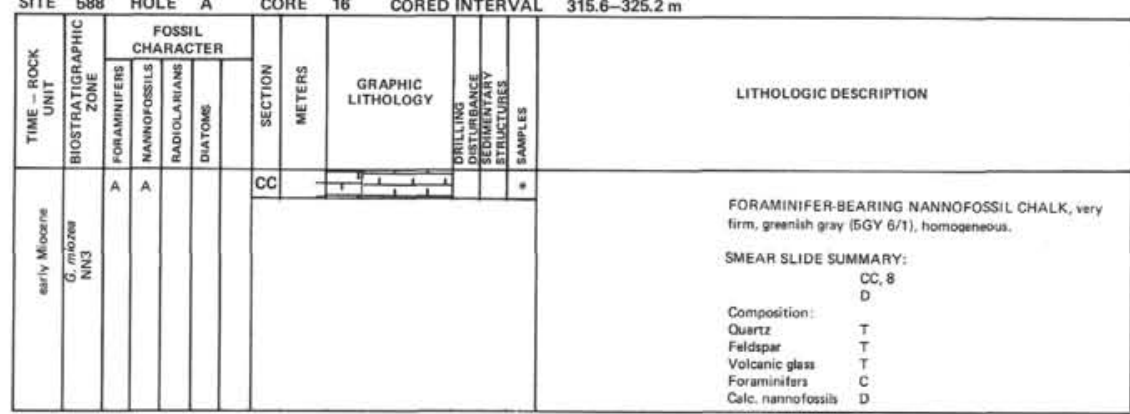

SITE 588 HOLE A CORE 17 CORED INTERVAL $325.2-334.8 \mathrm{~m}$

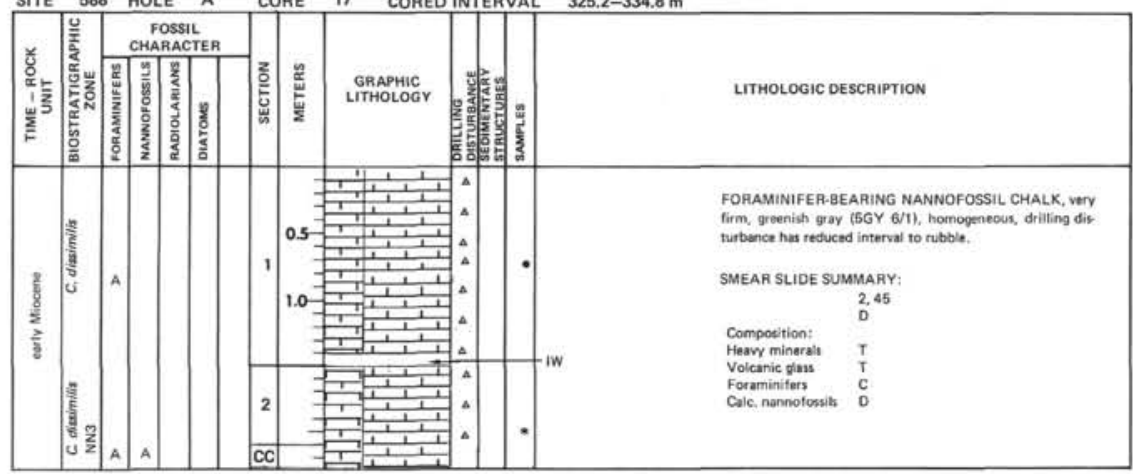

SITE 588 HOLE A CORE 18 CORED INTERVAL $334.8-344.4 \mathrm{~m}$

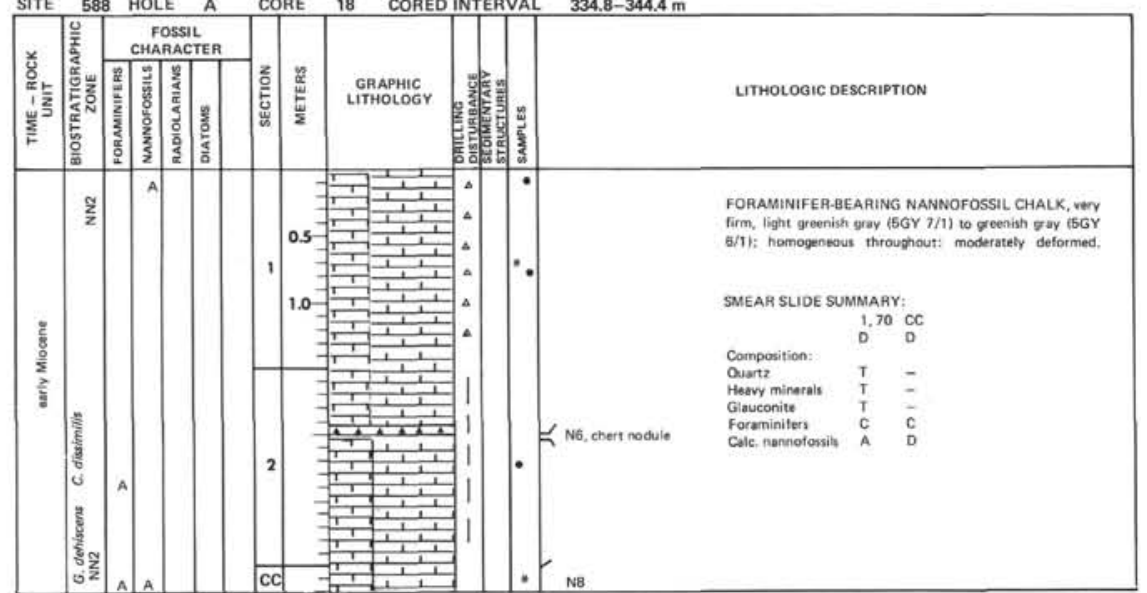



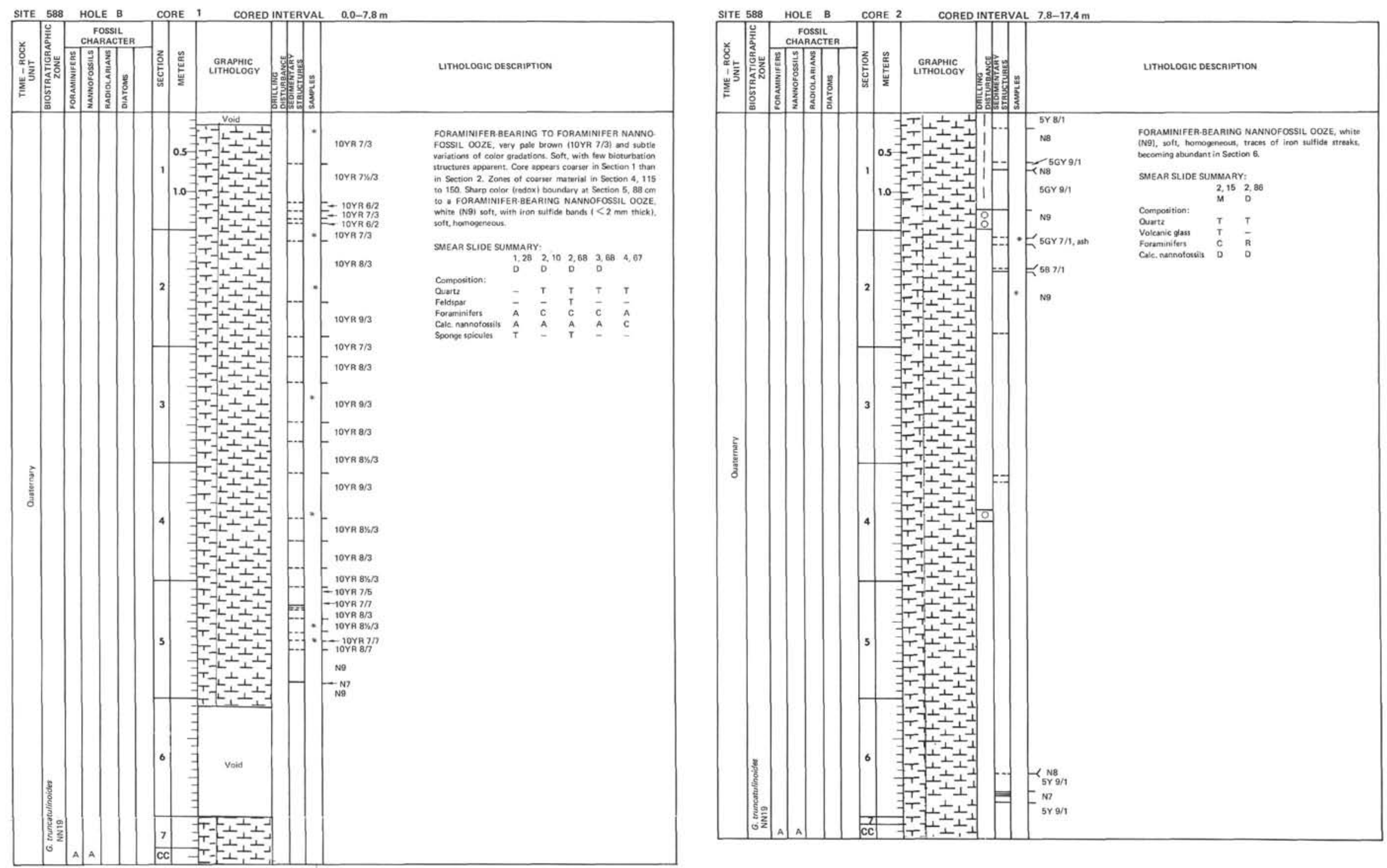

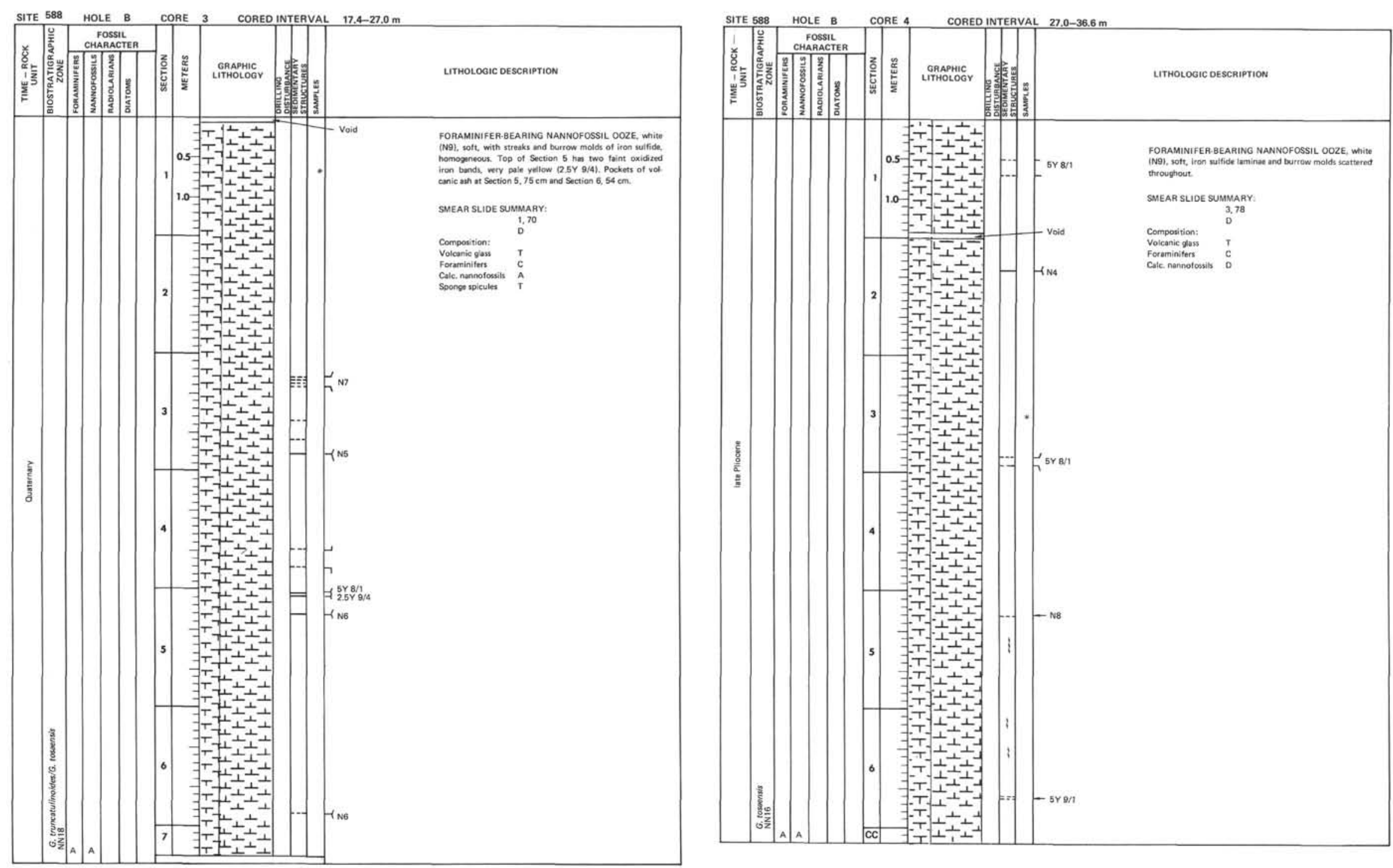

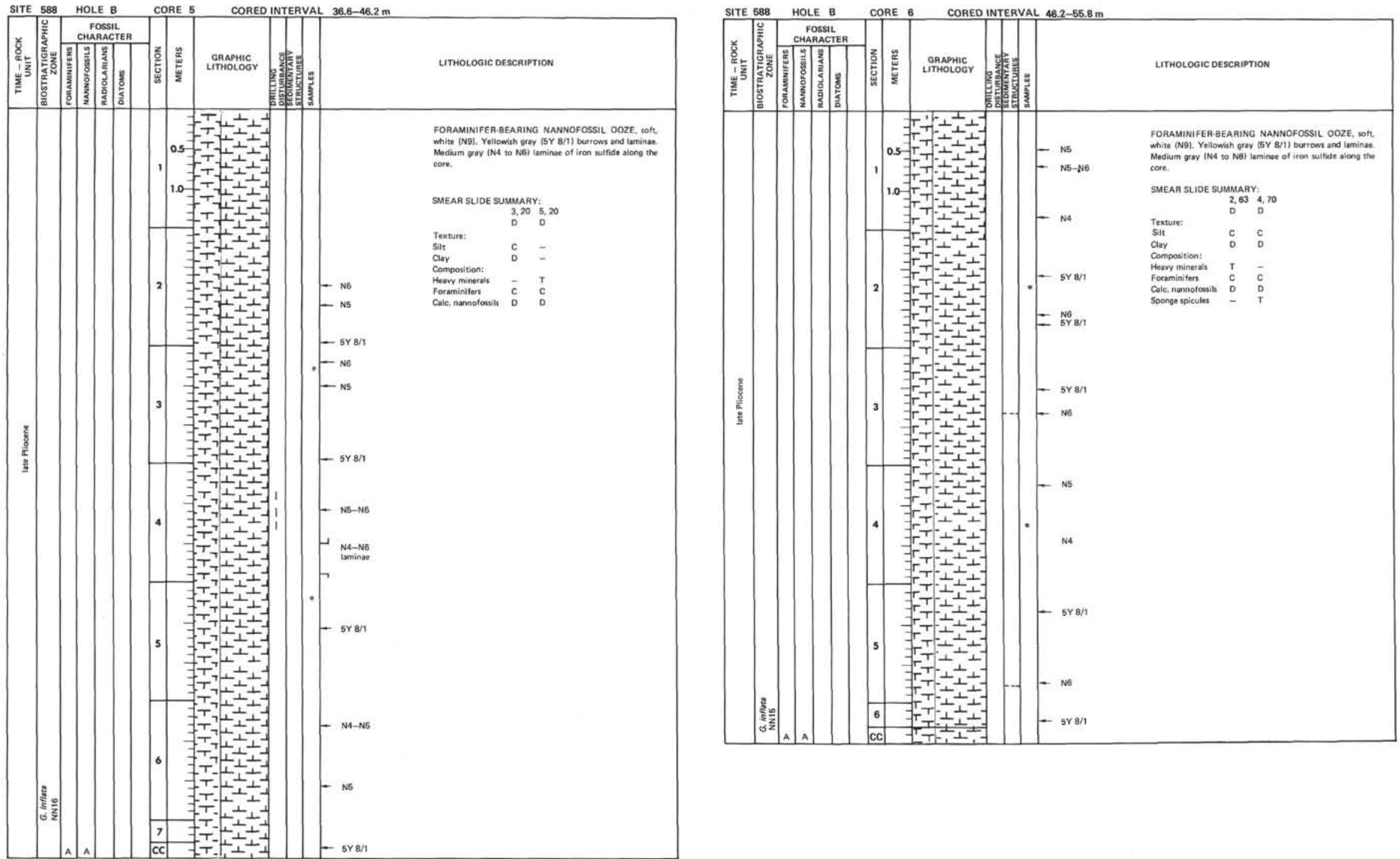

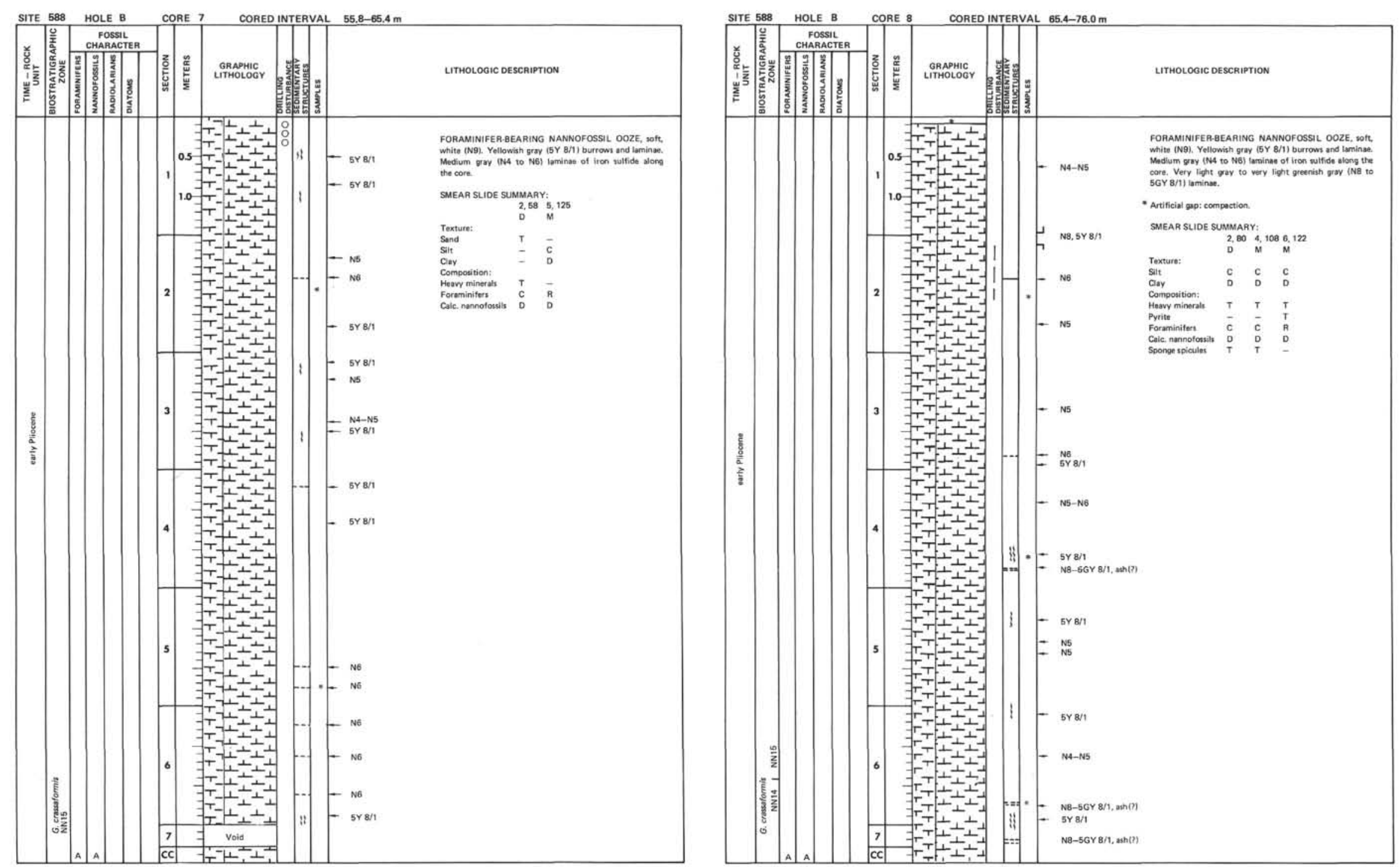

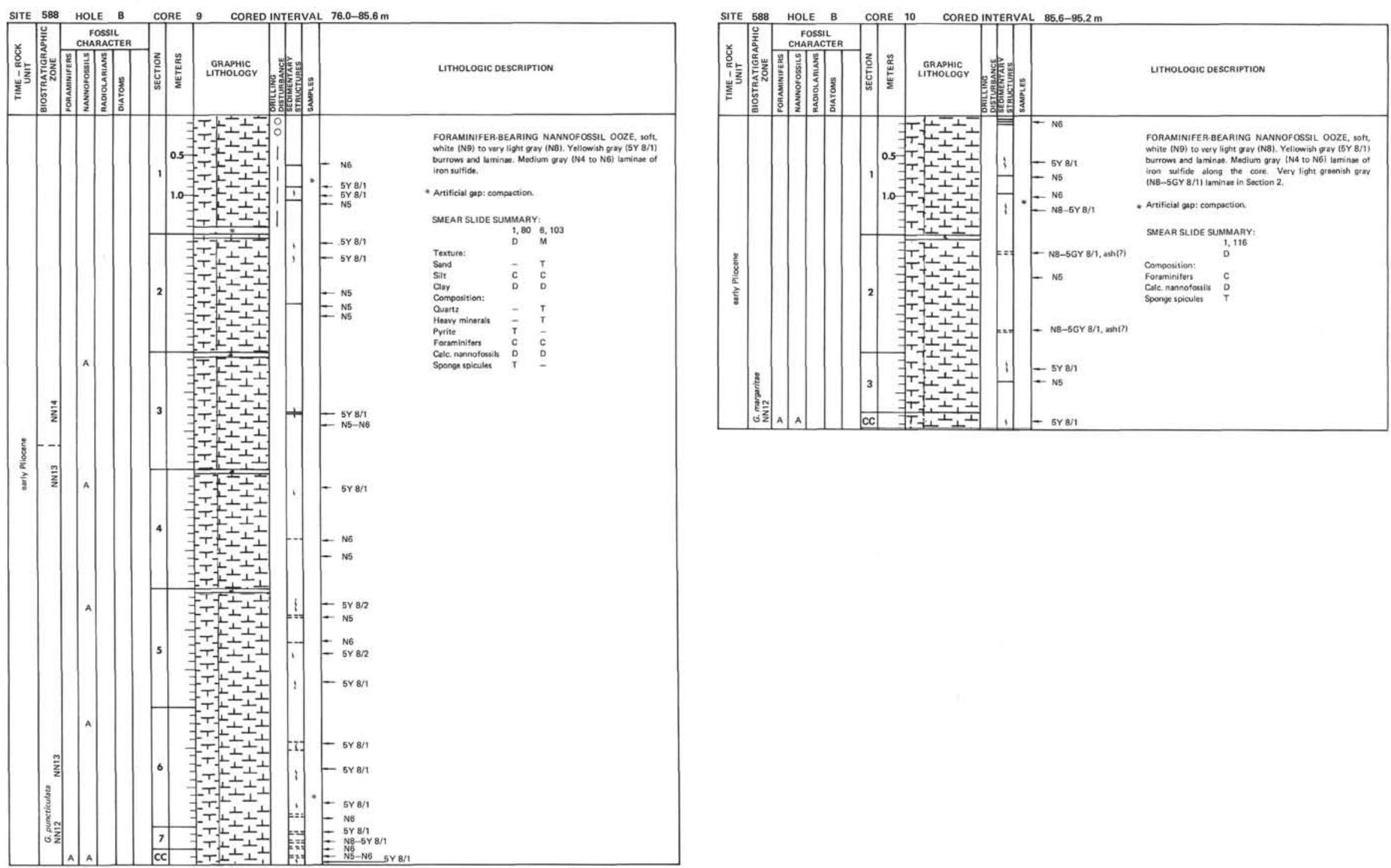

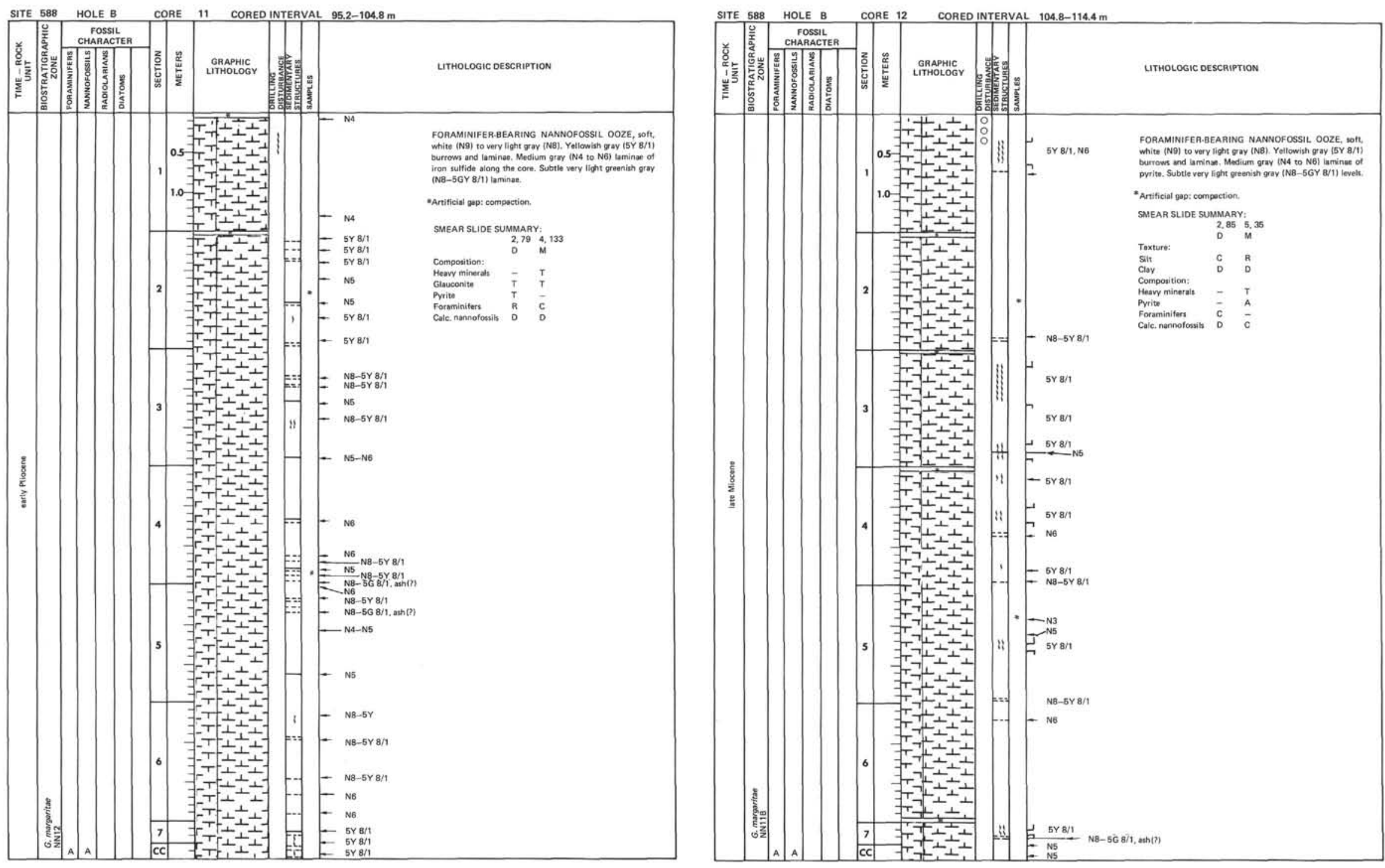

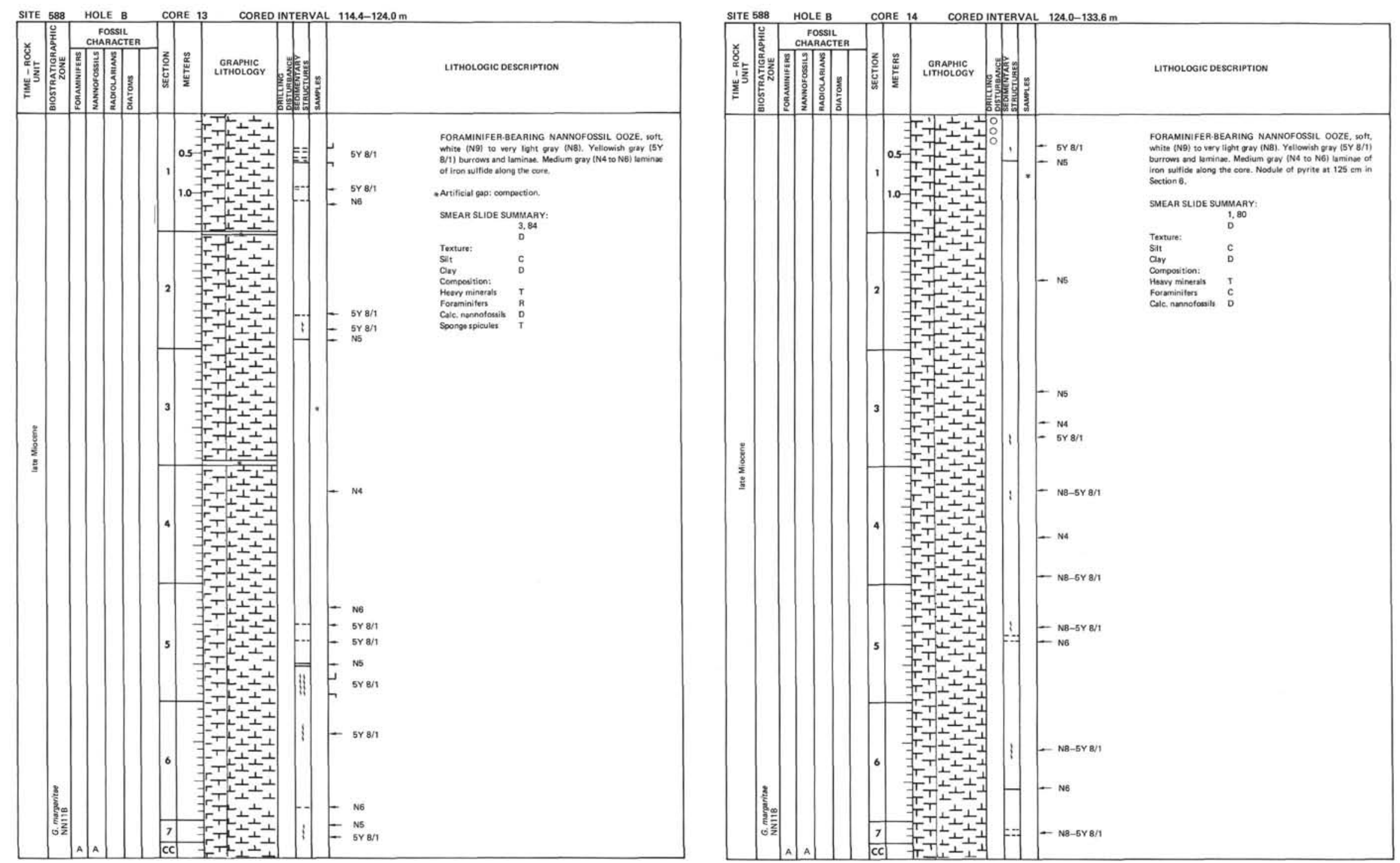

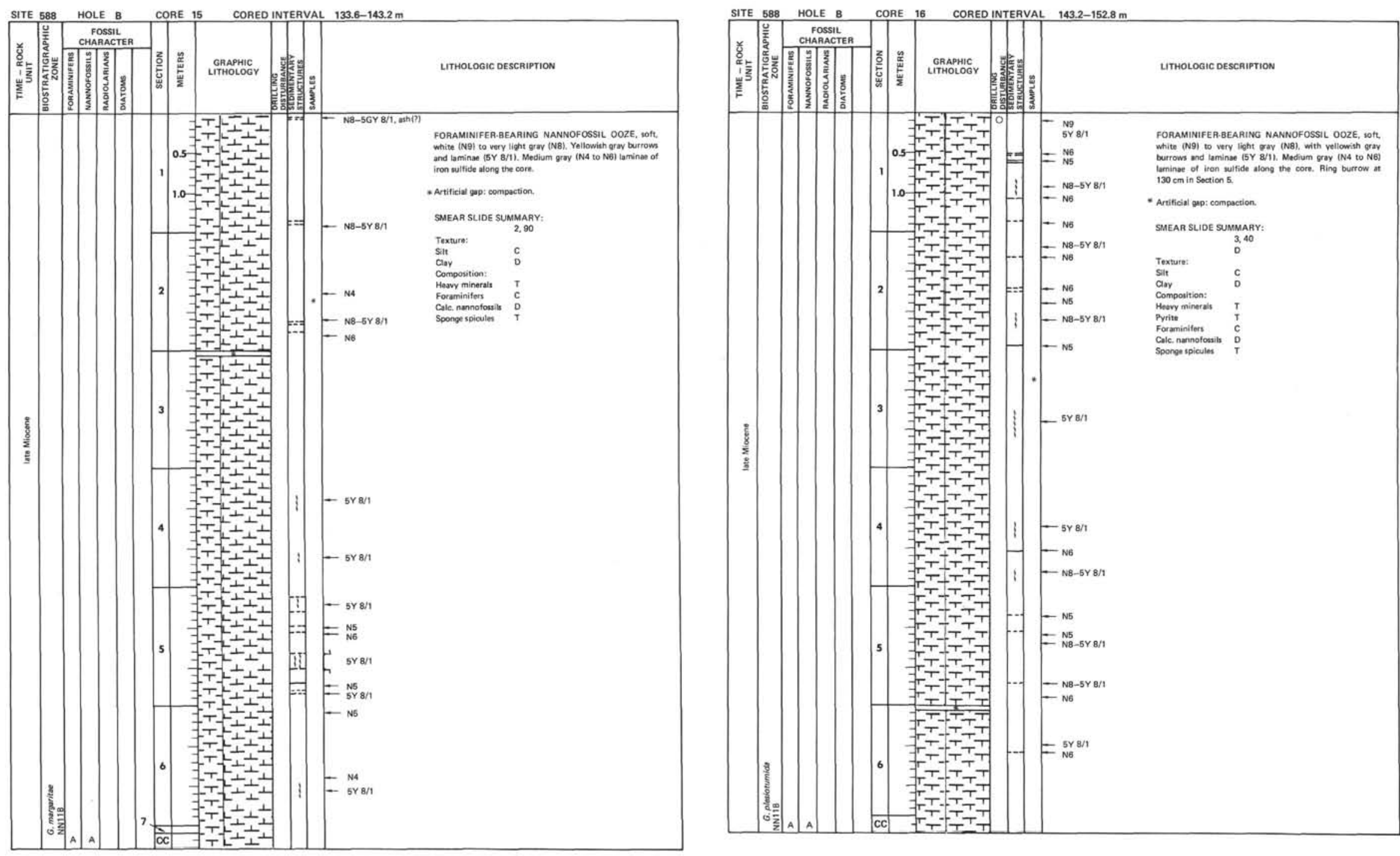

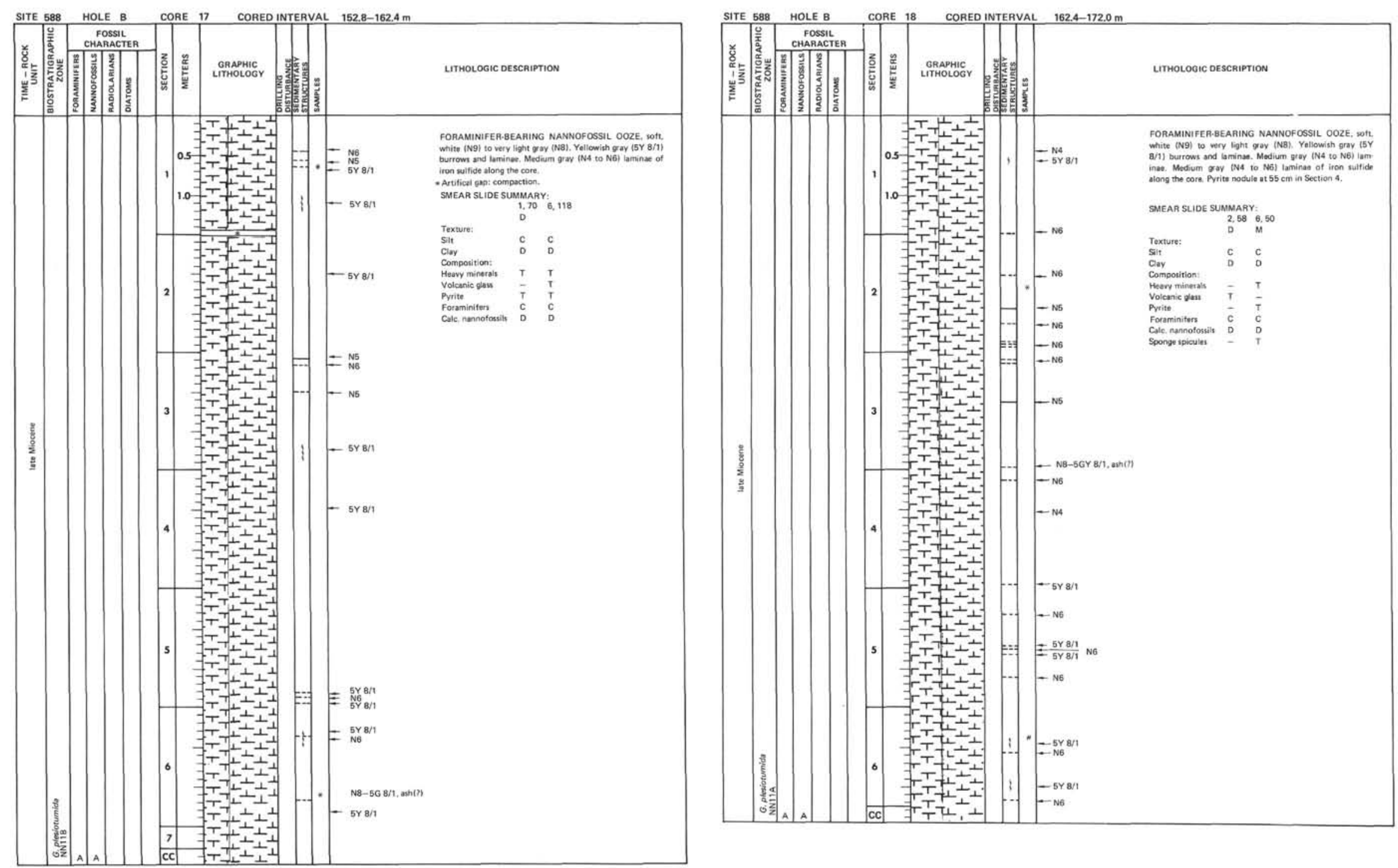

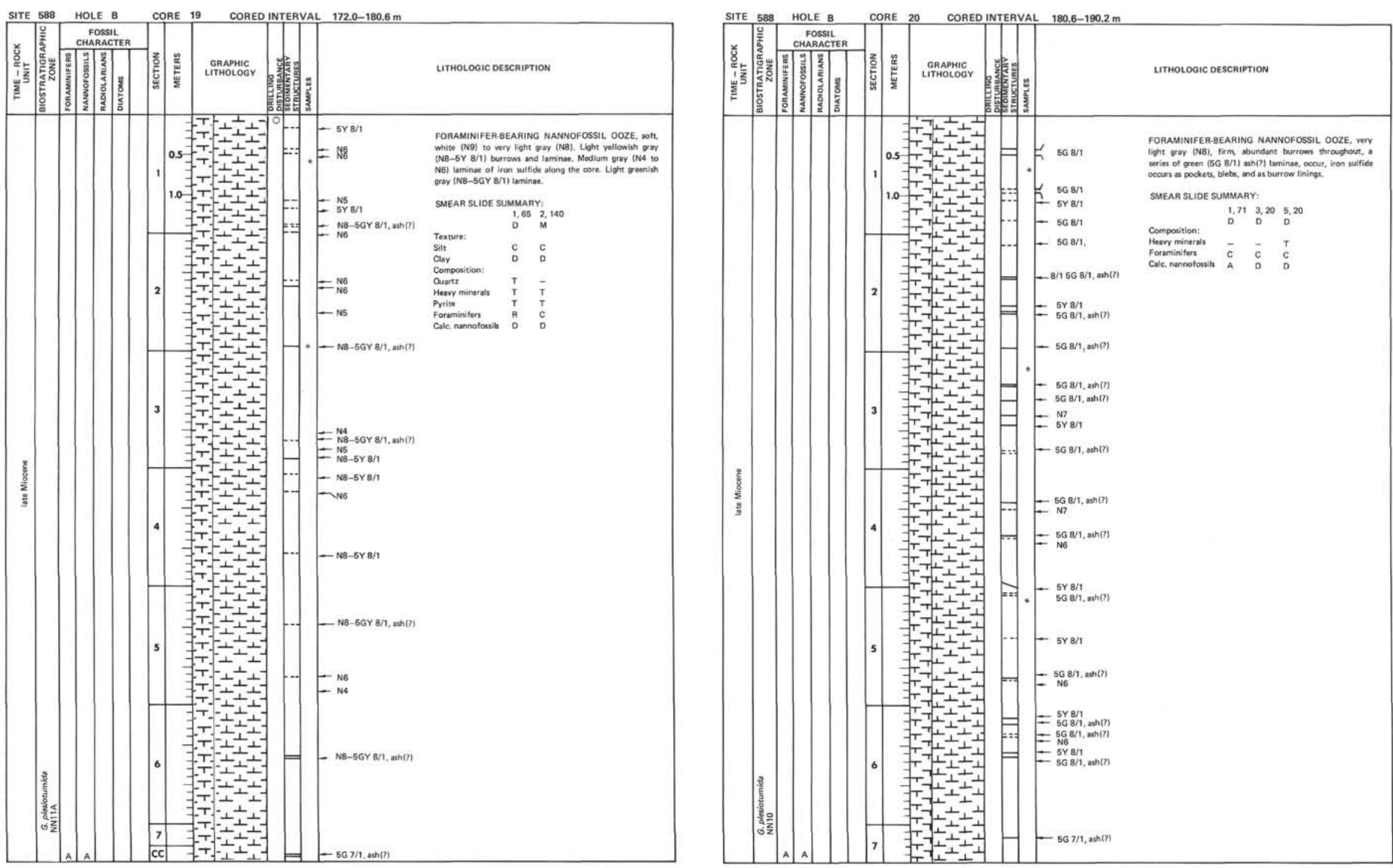

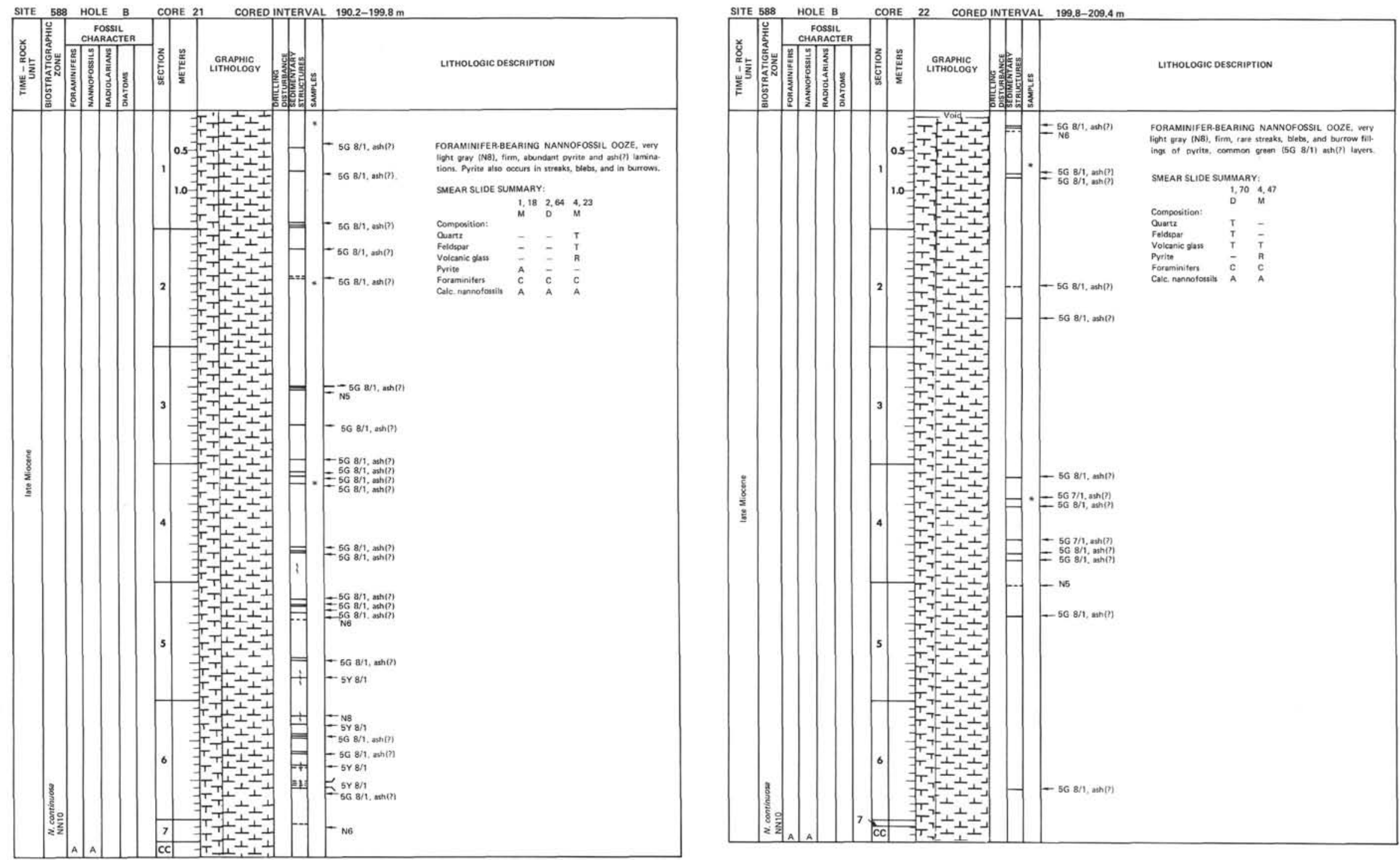

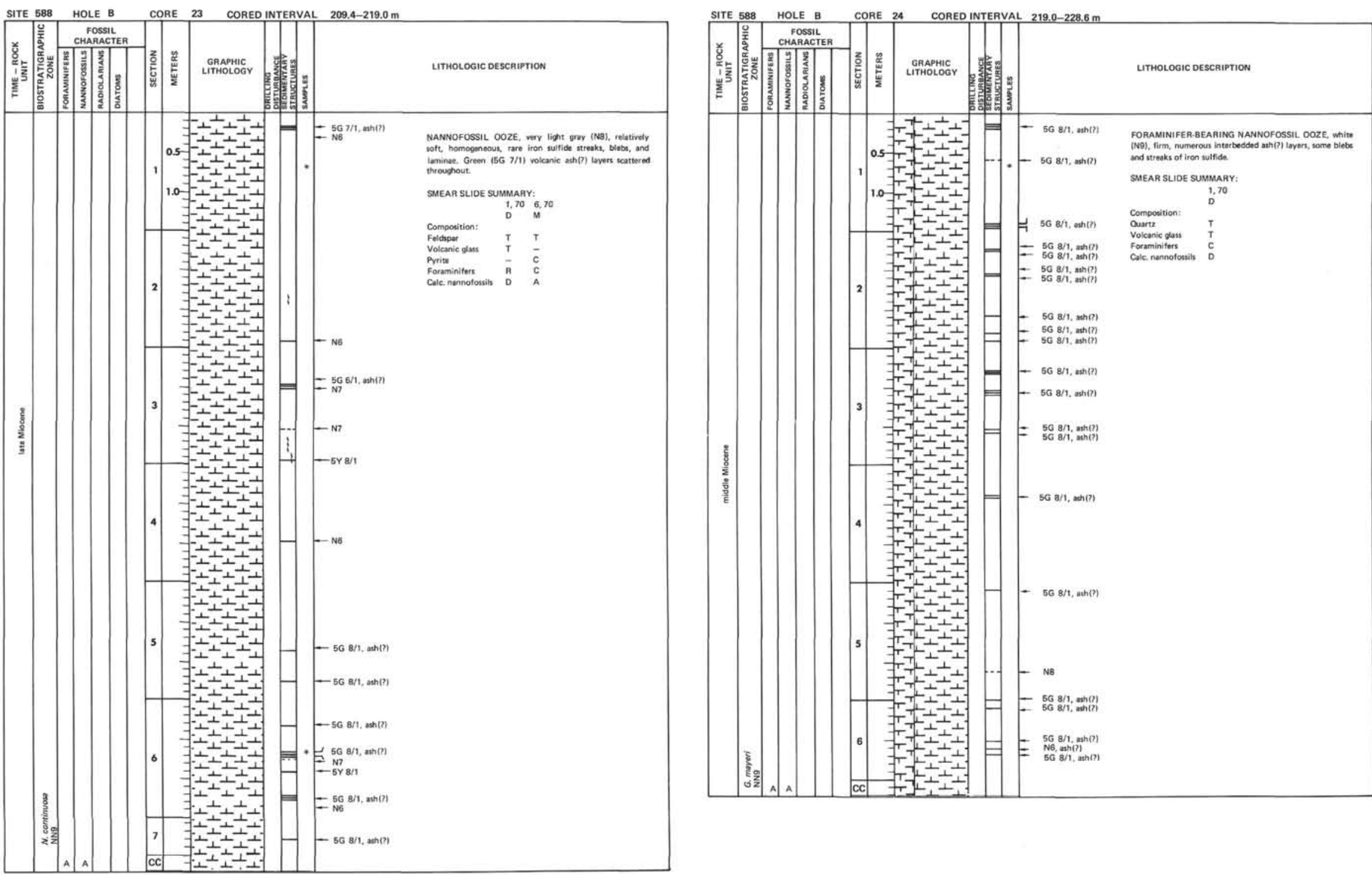


\section{s}

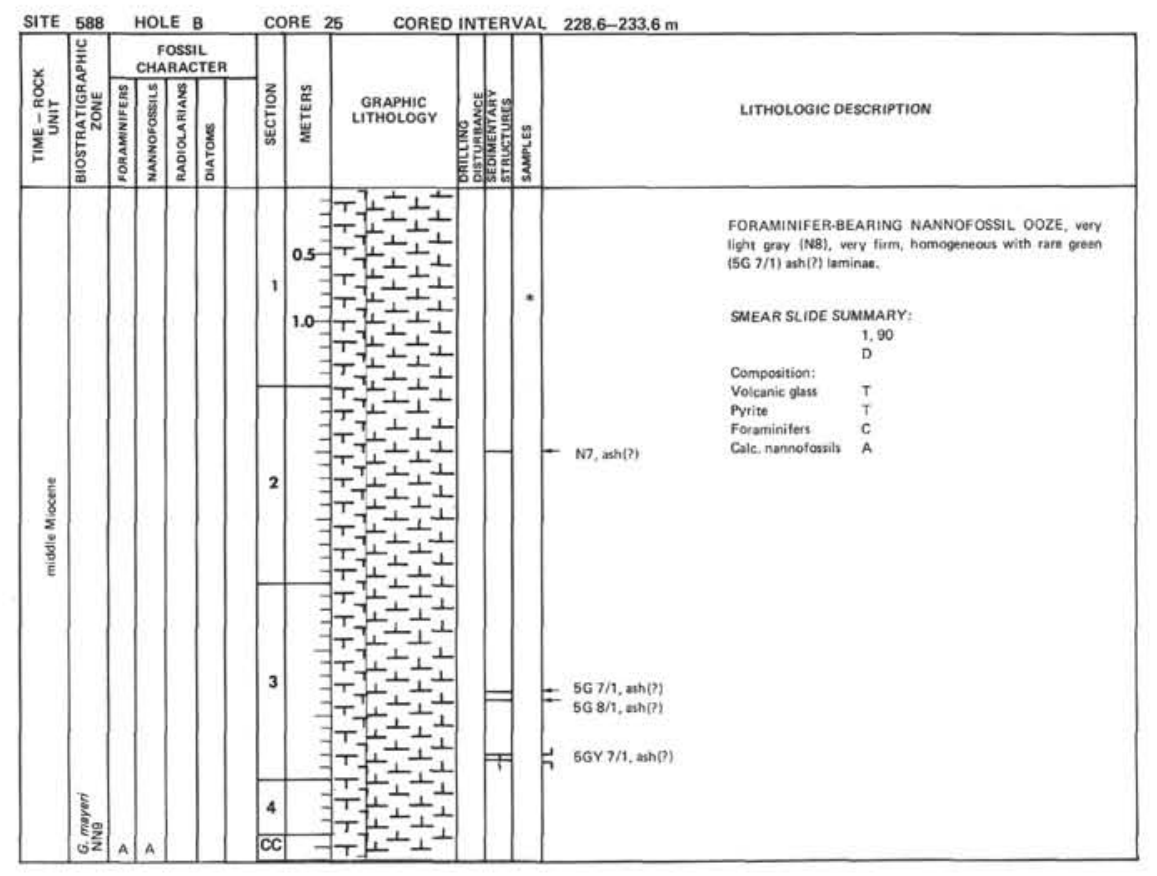

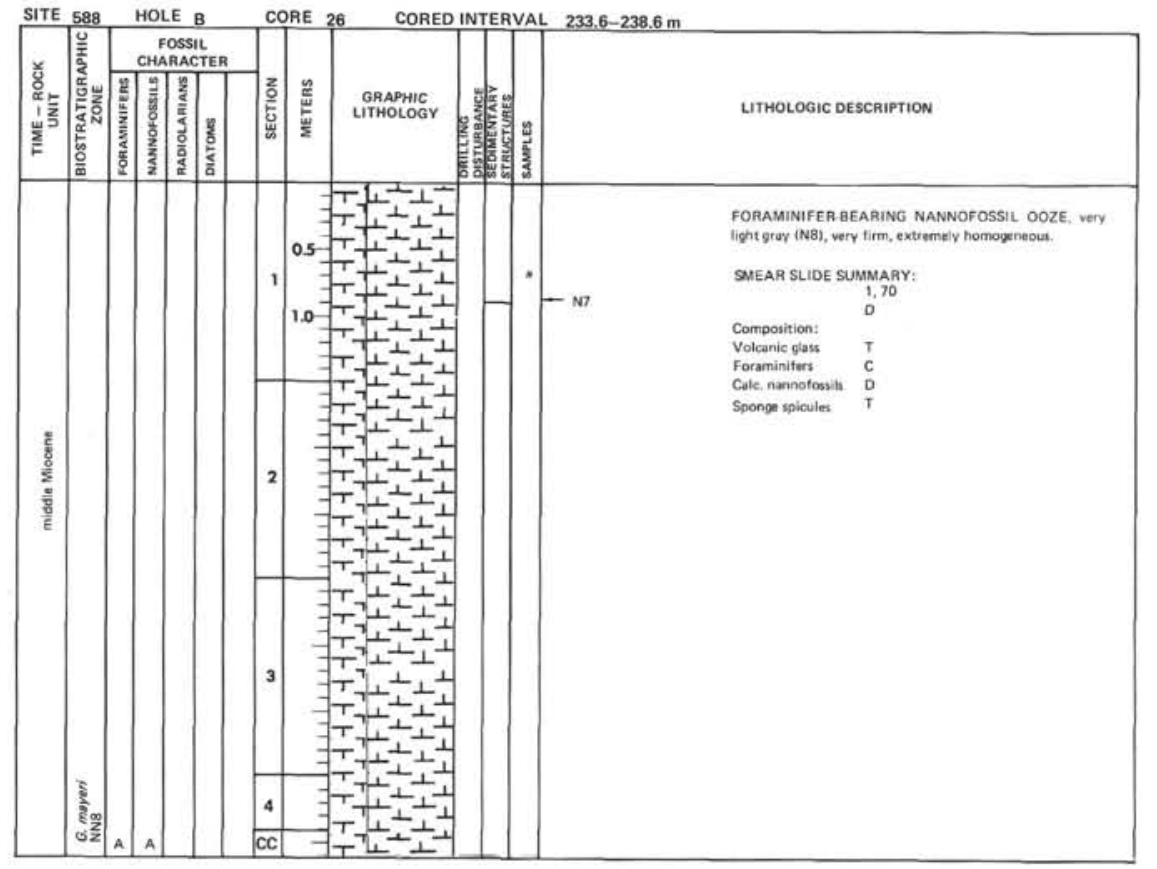



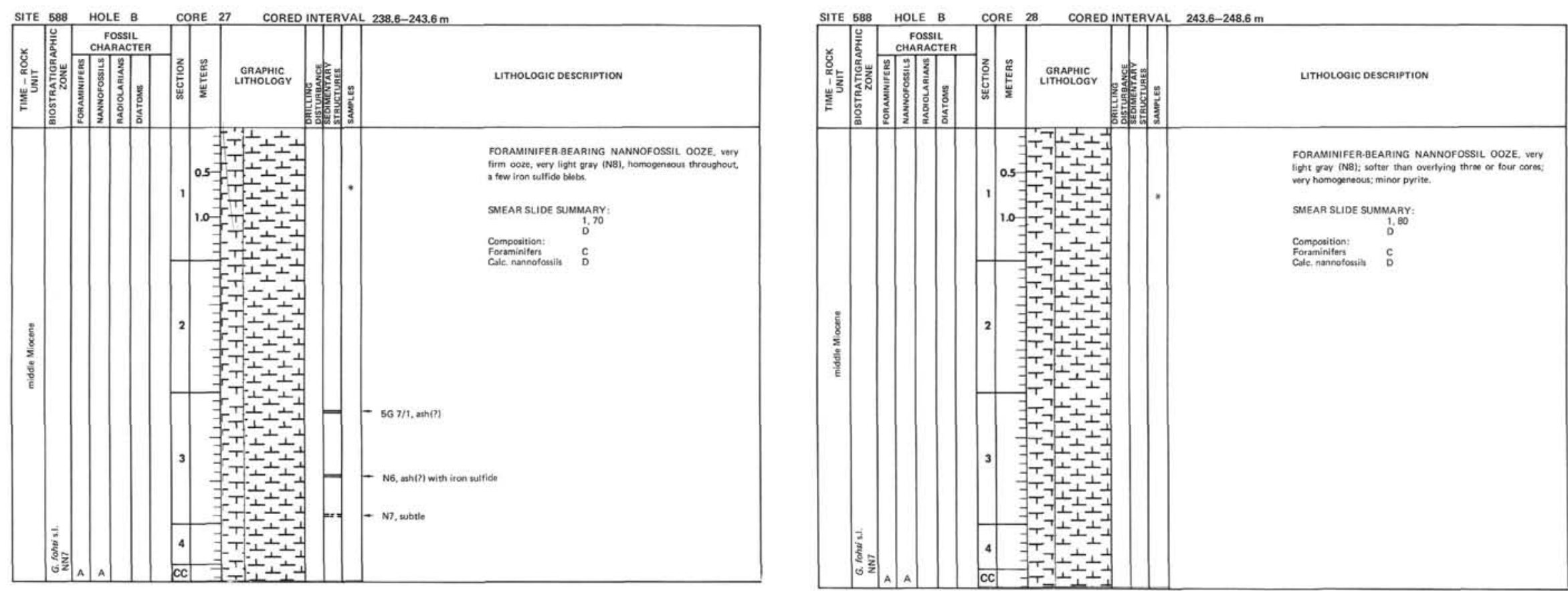


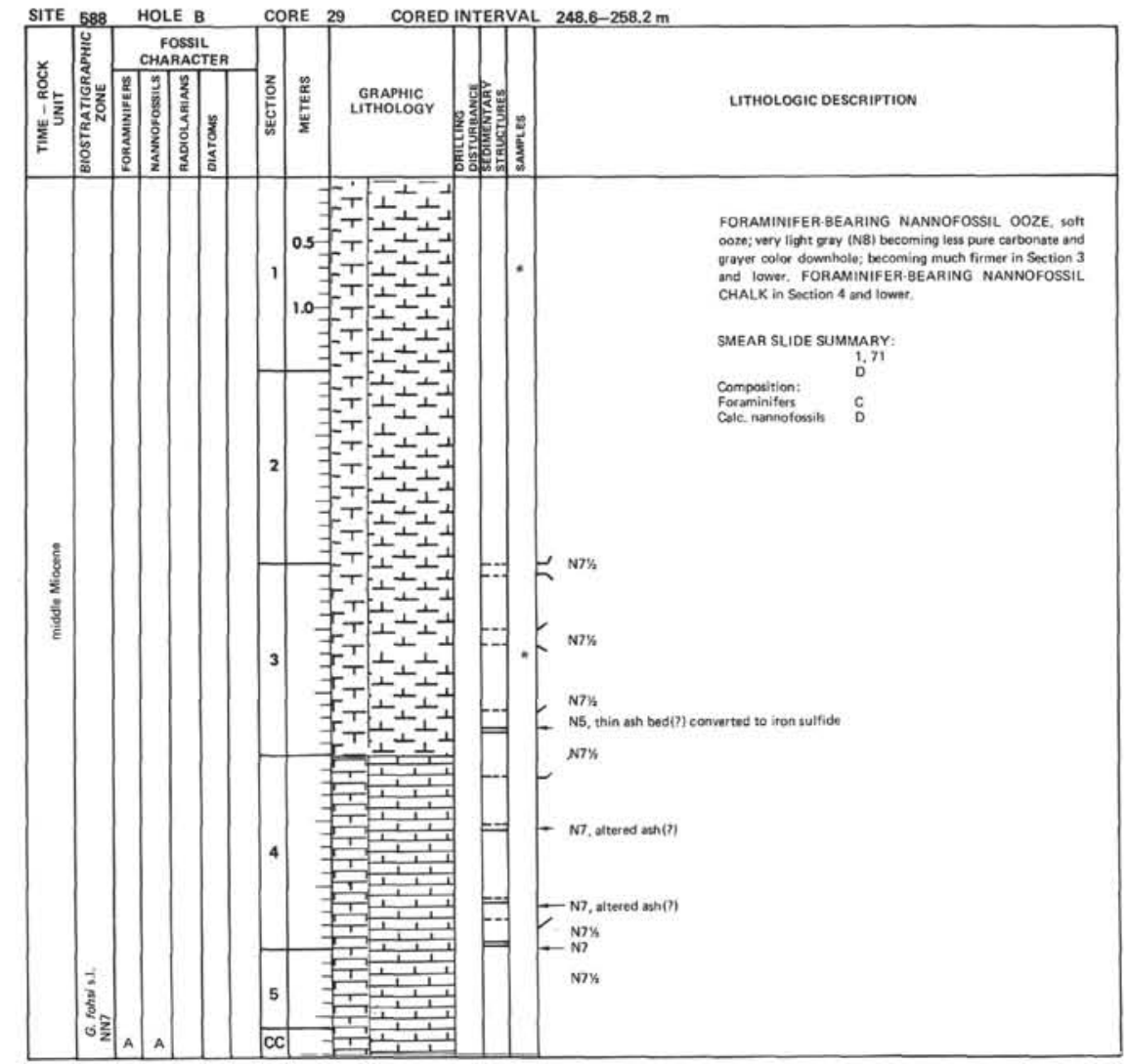

SITE 588 HOLE B CORE 30 CORED INTERVAL $258.2-267.8 \mathrm{~m}$

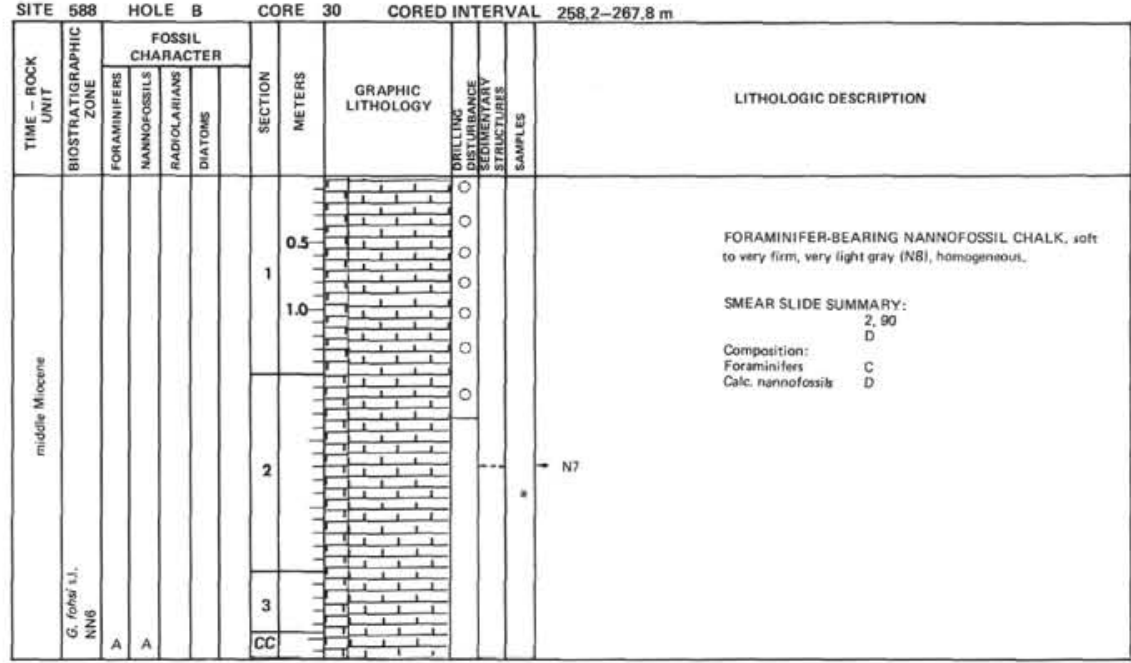

SITE 588 HOLE B CORE 31 CORED INTERVAL 267.8-277.4m

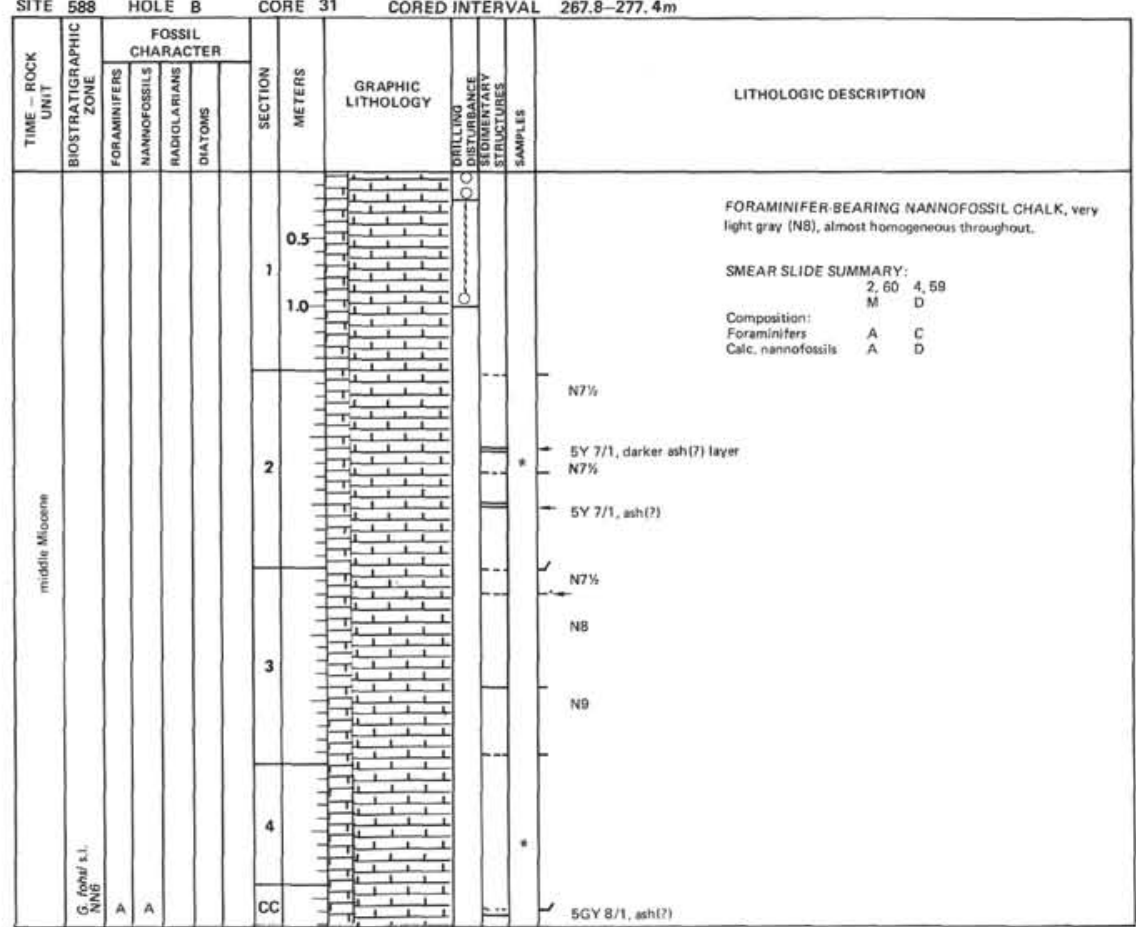



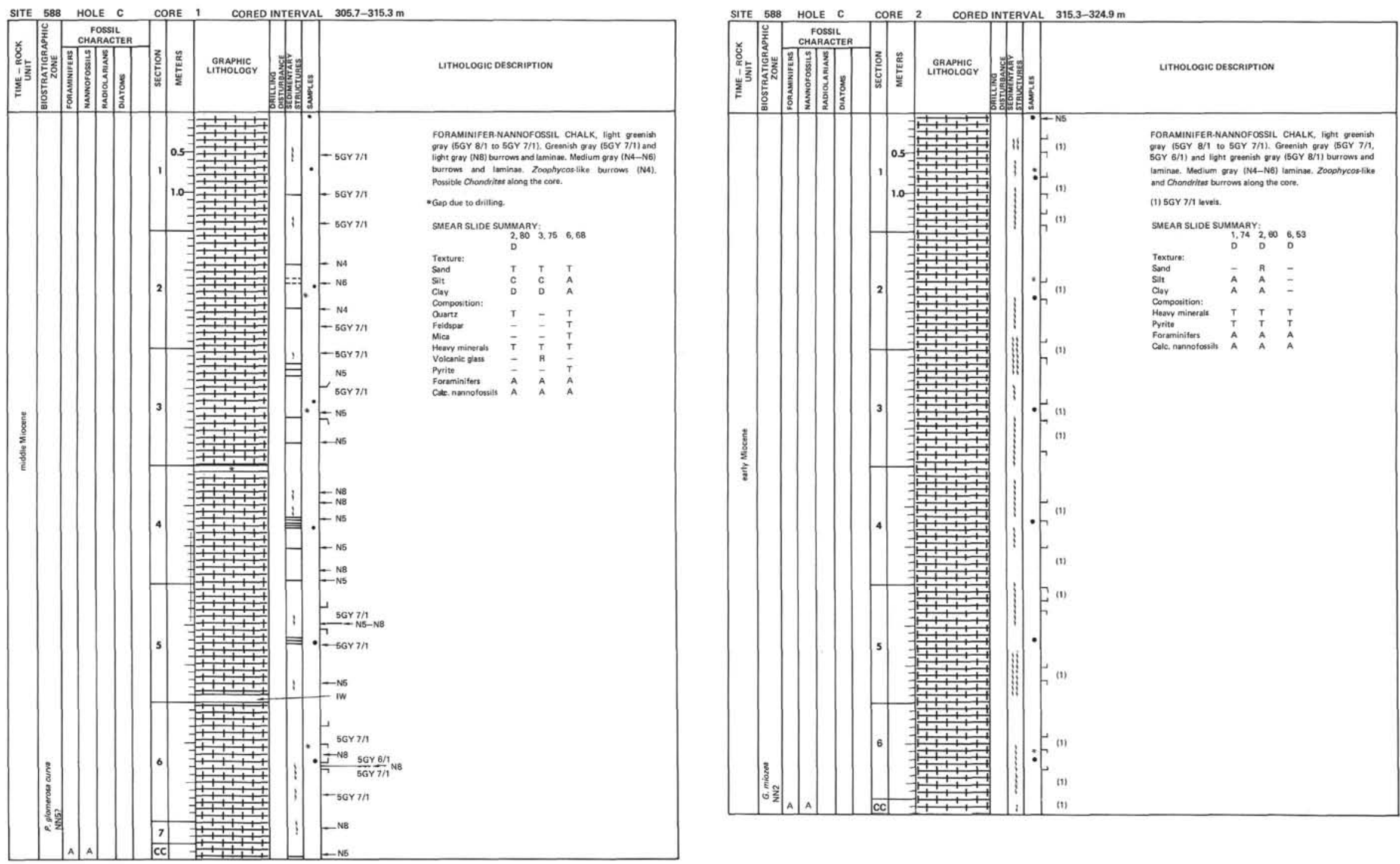

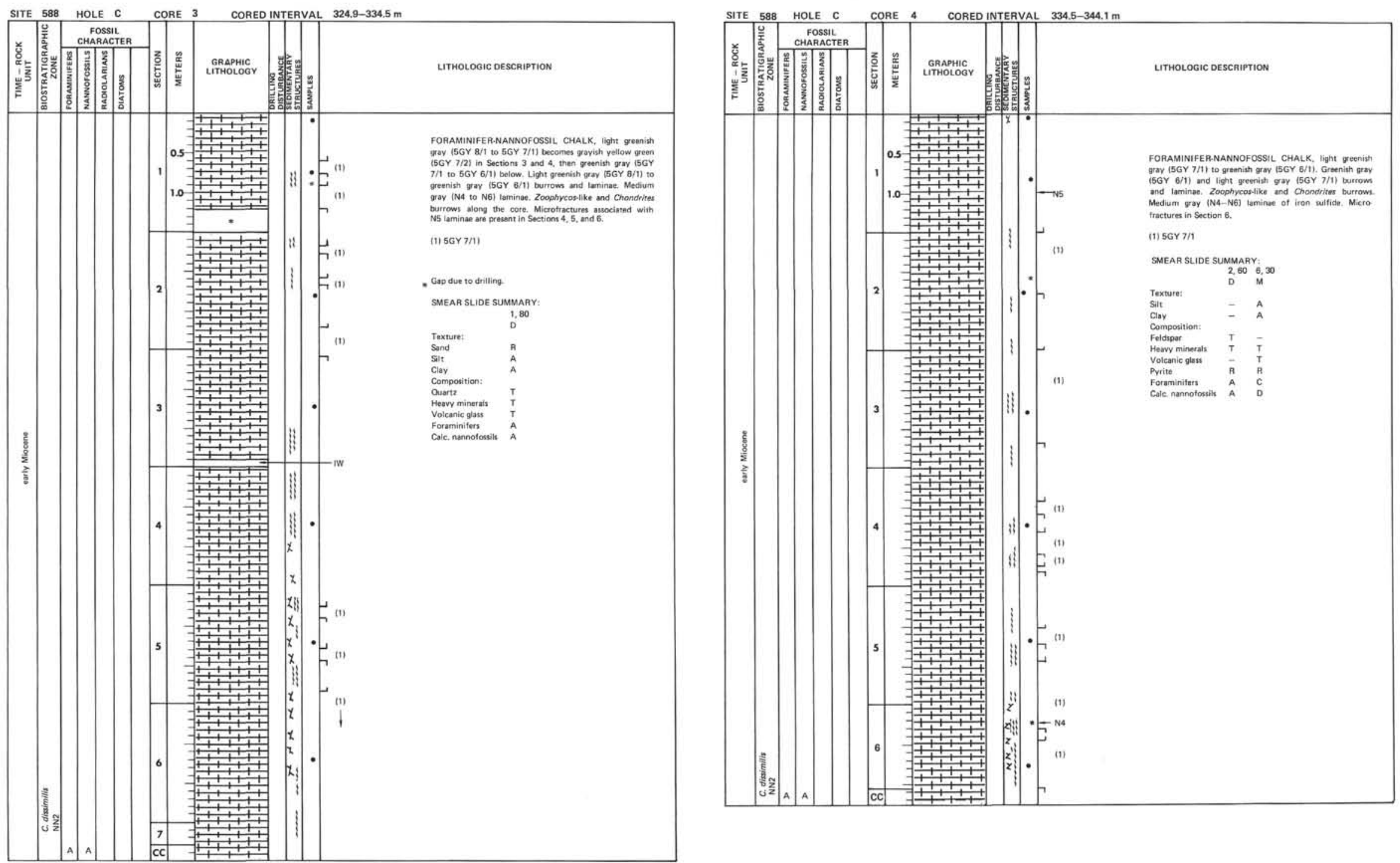

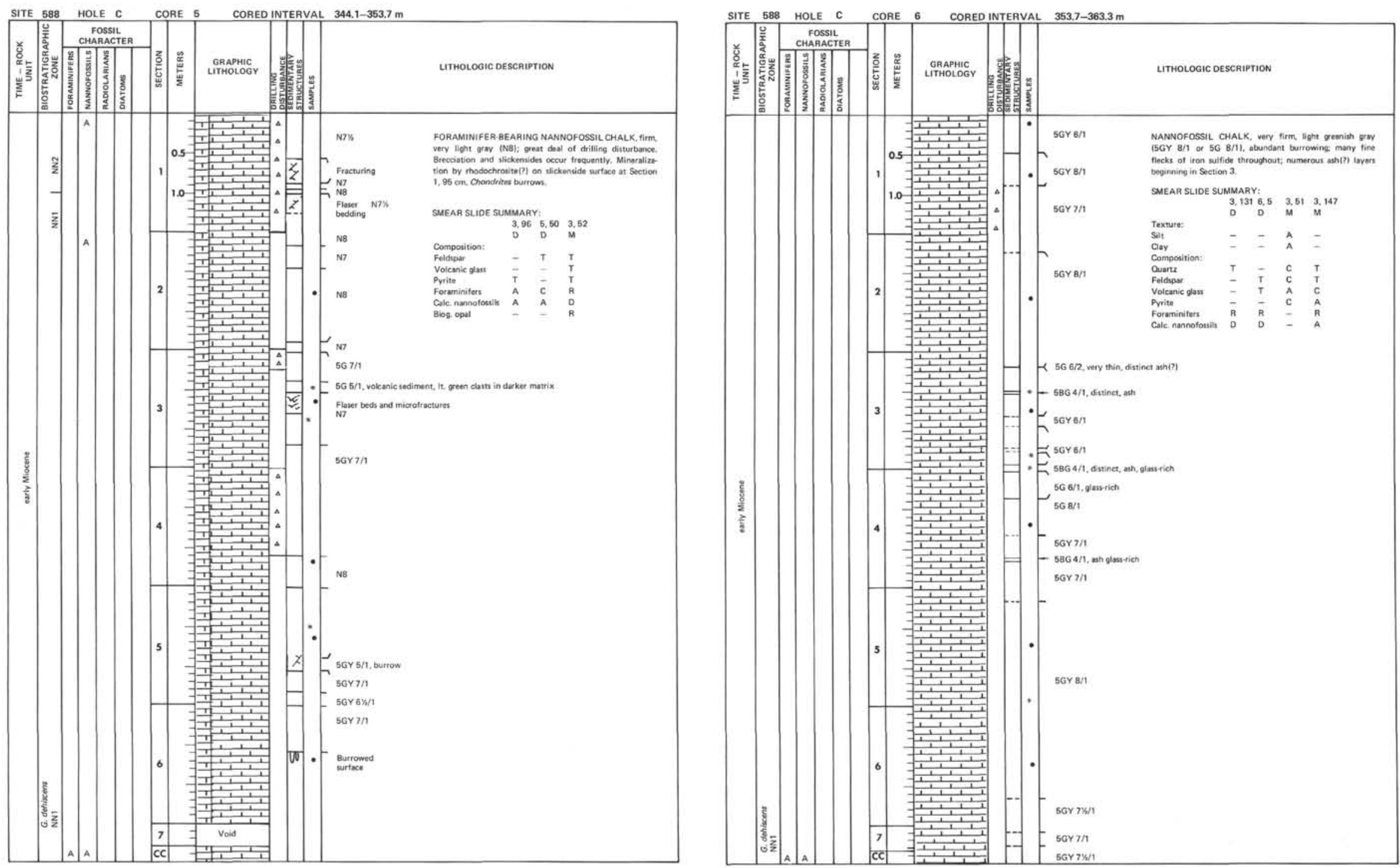

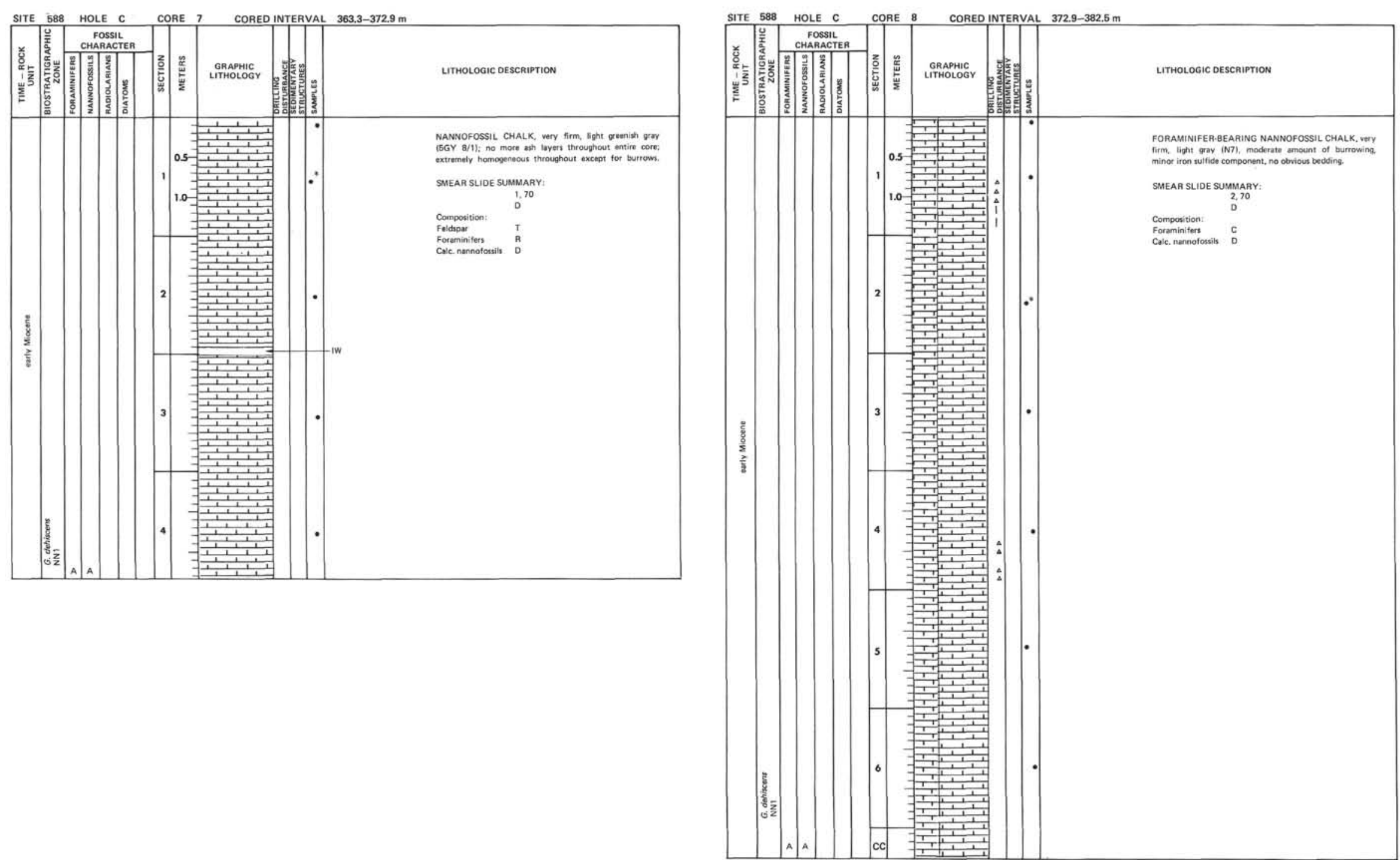

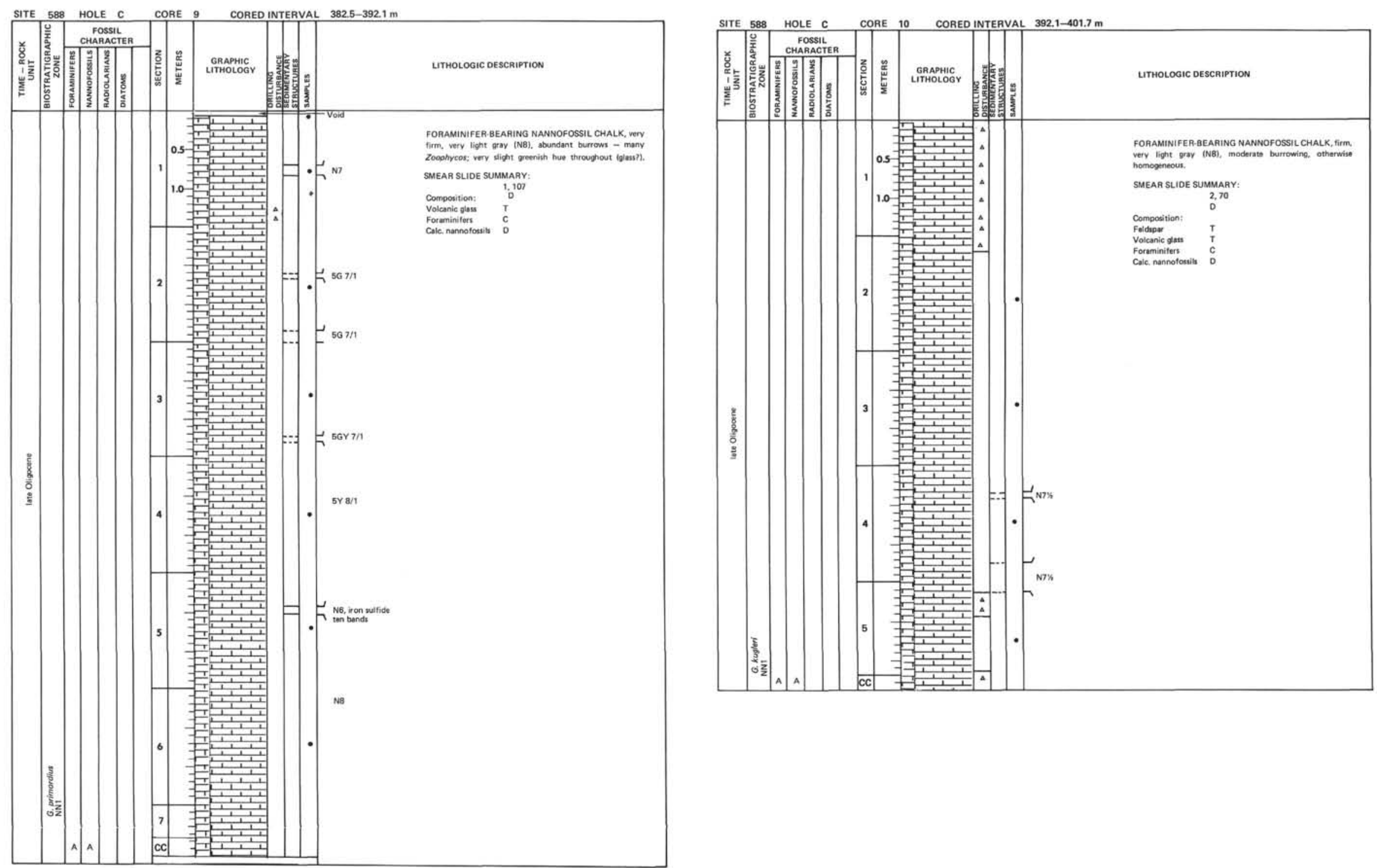

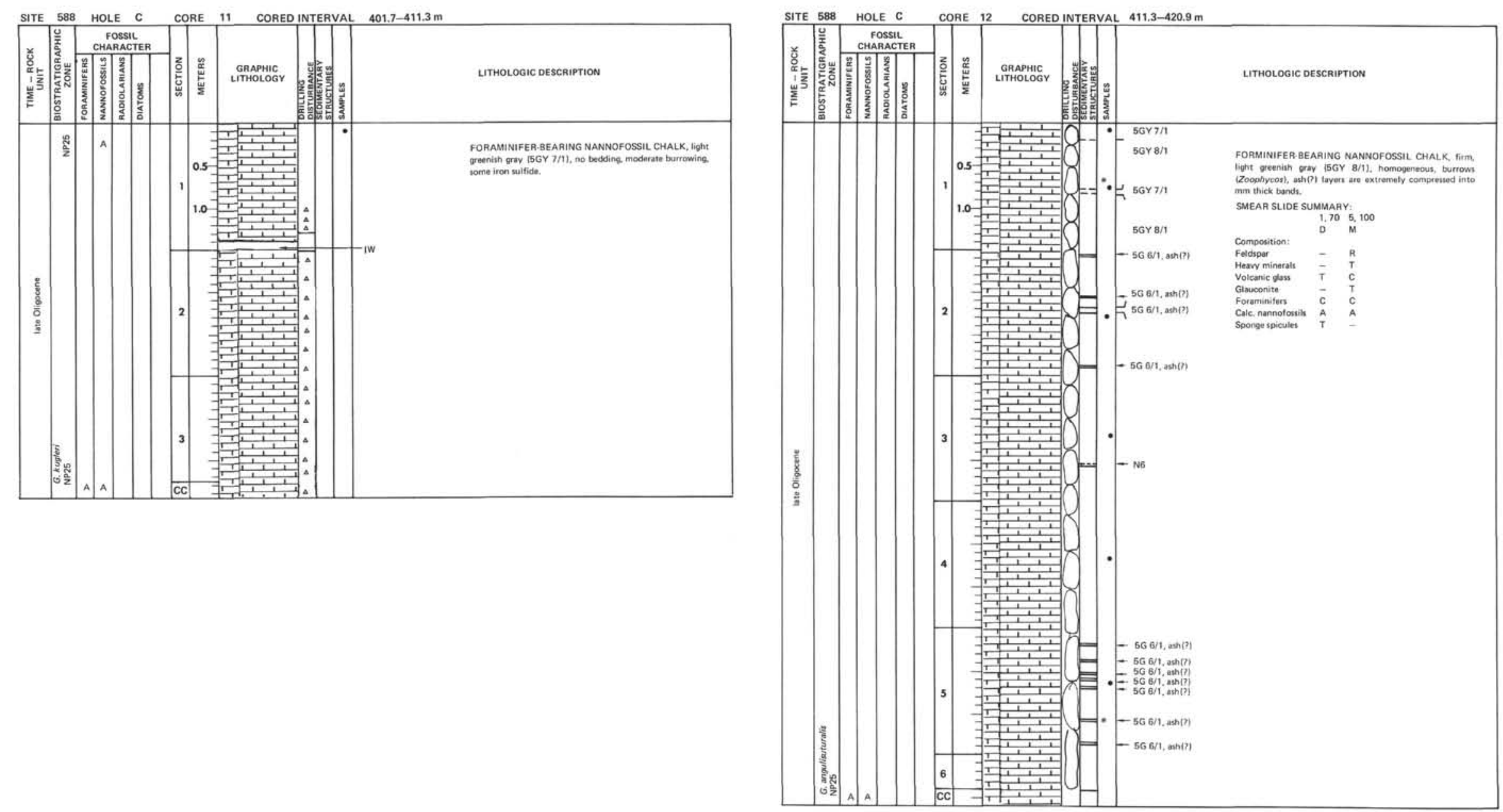

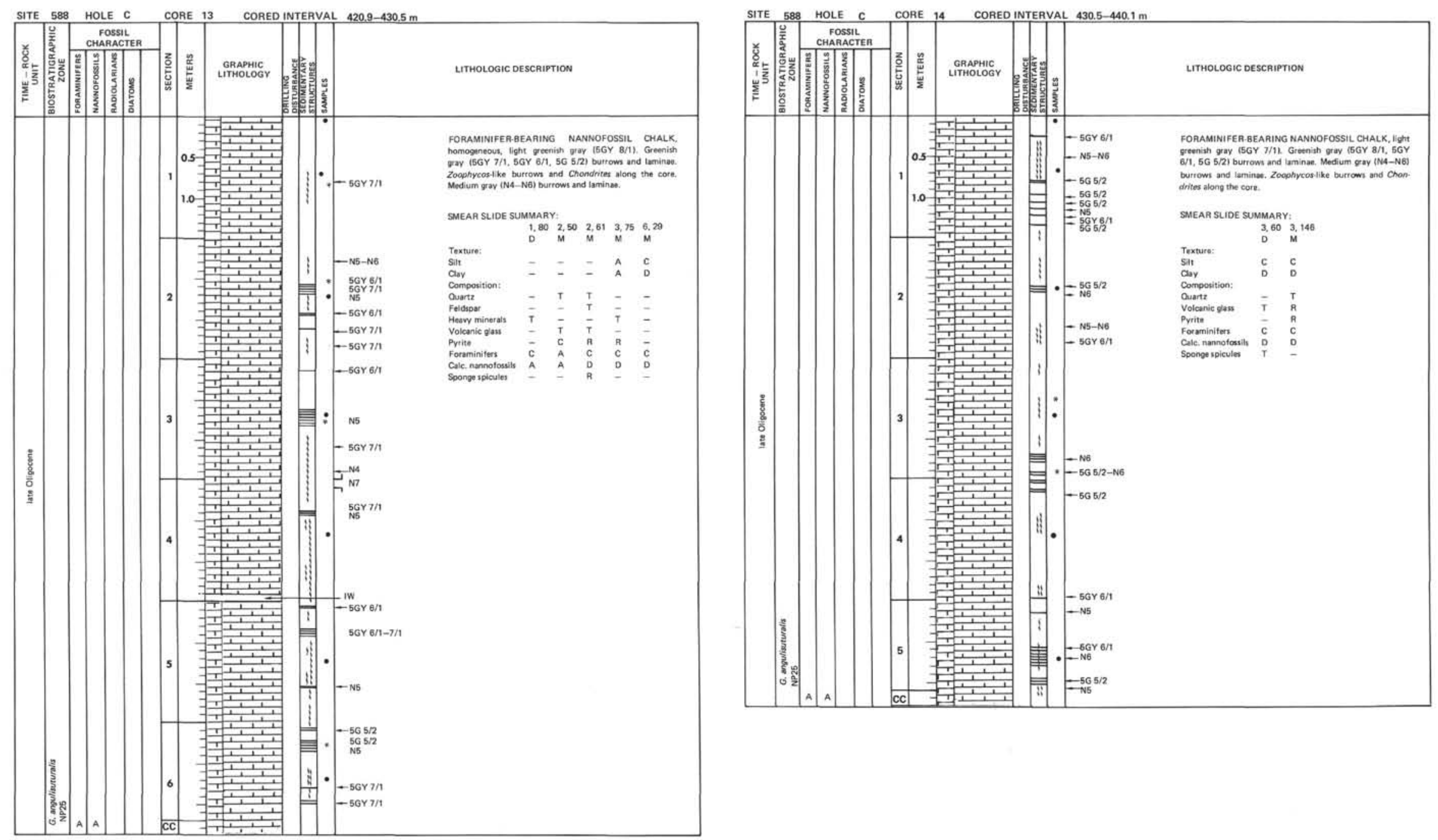


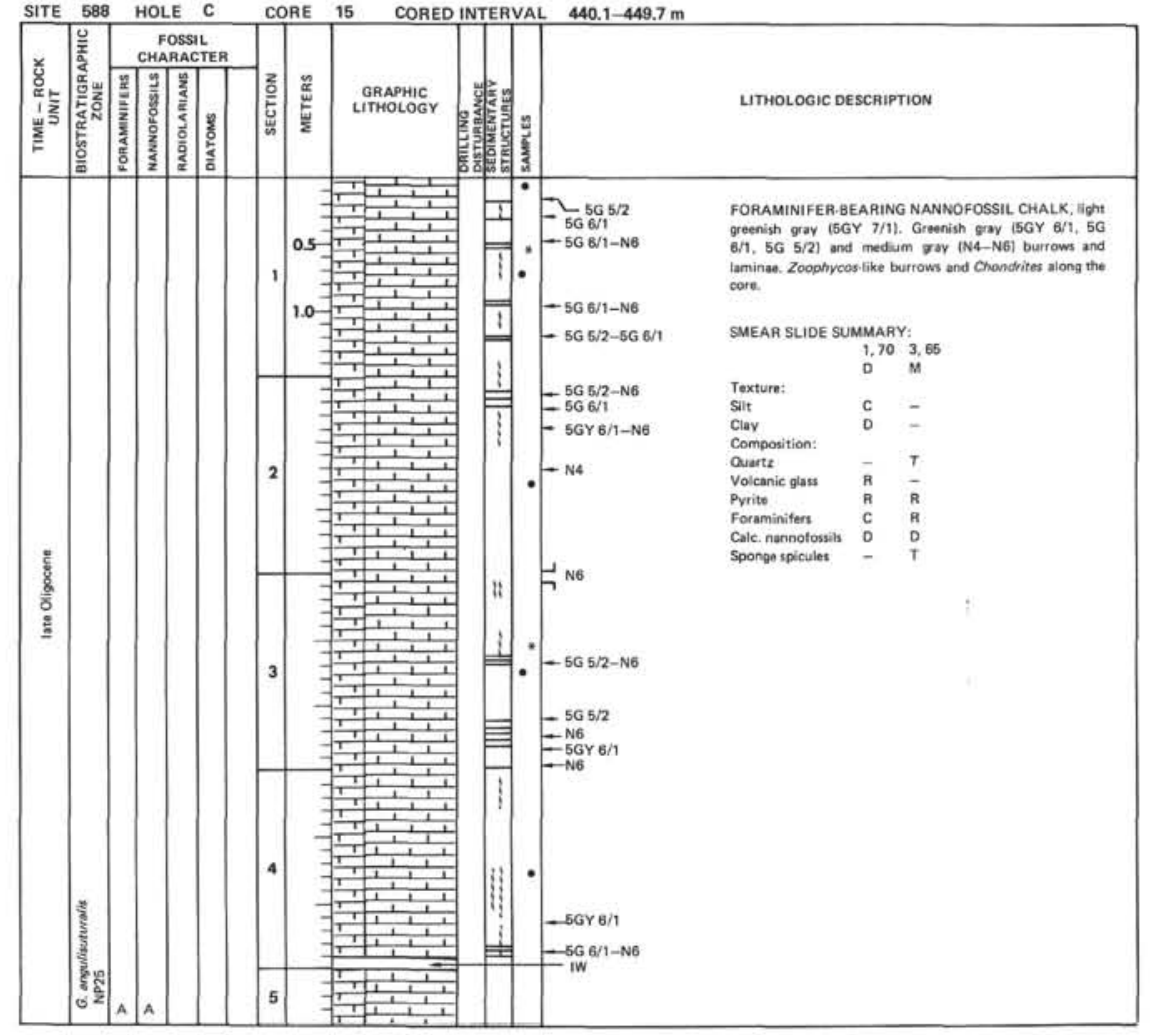

SITE 588 HOLE C CORE 16 CORED INTERVAL $449.7-459.3 \mathrm{~m}$

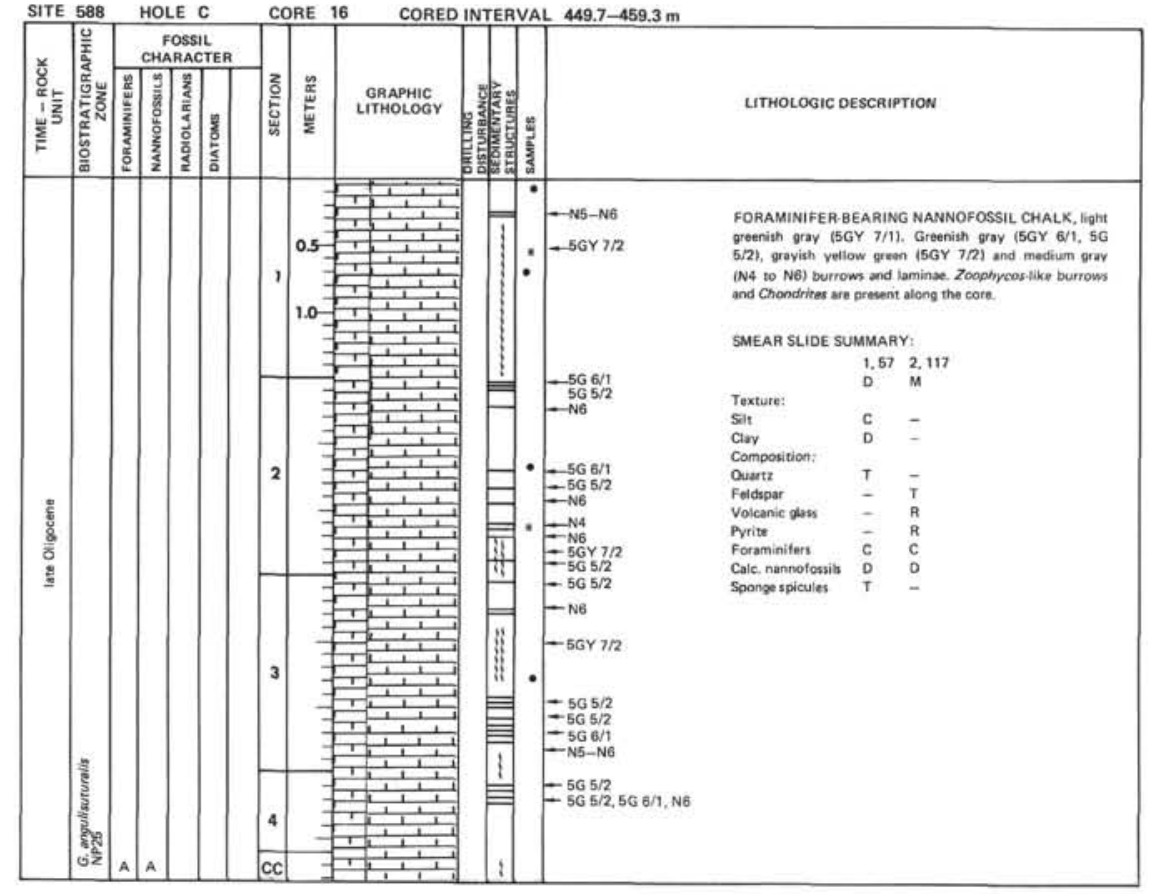




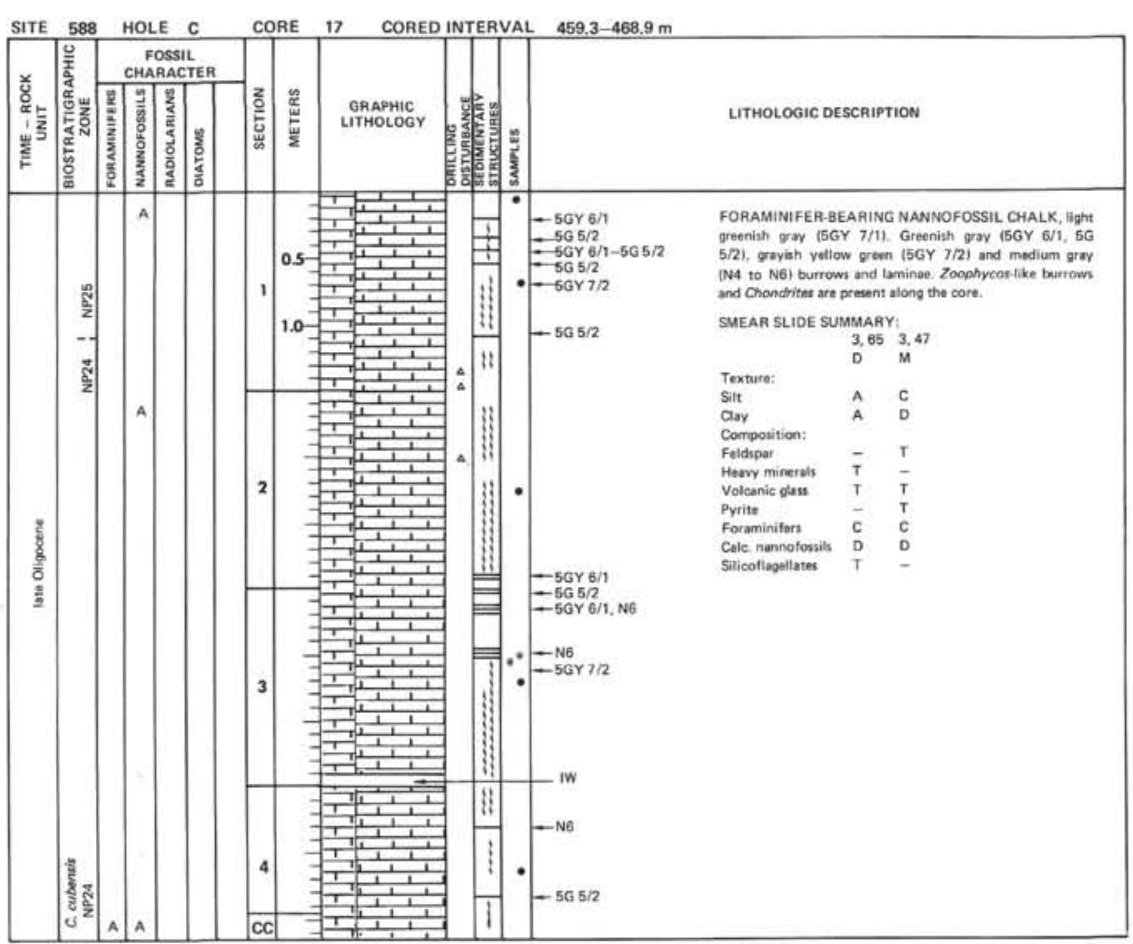

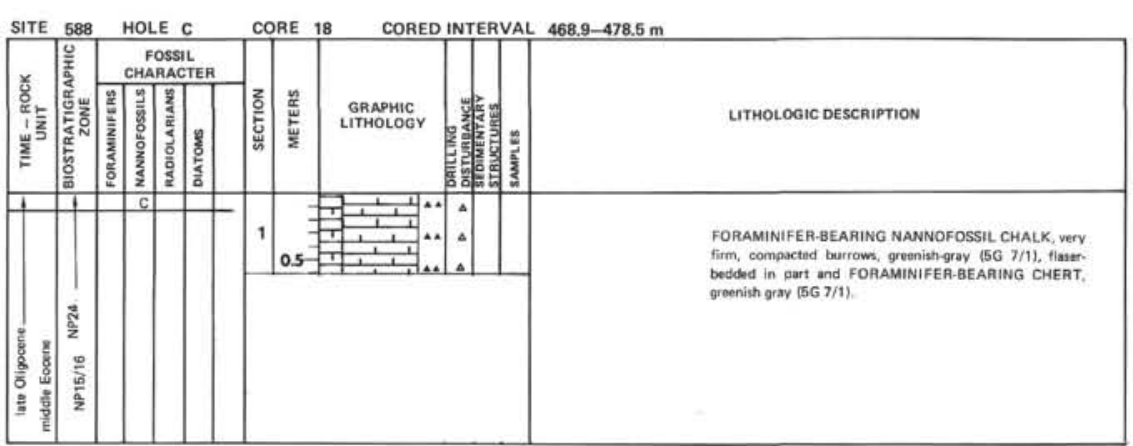

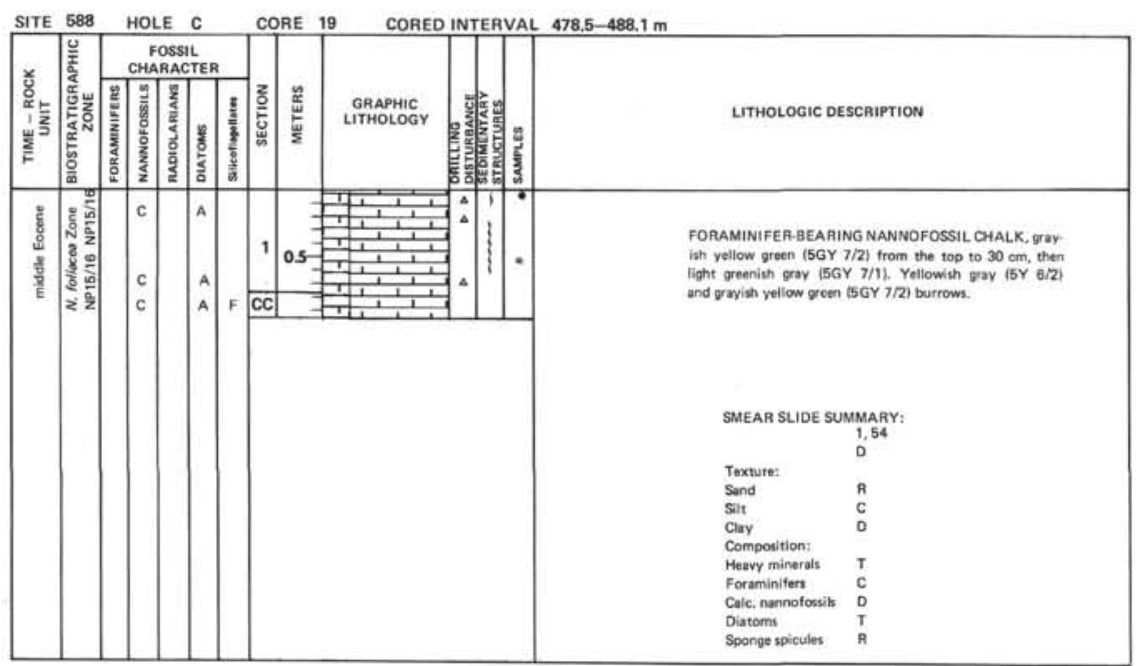




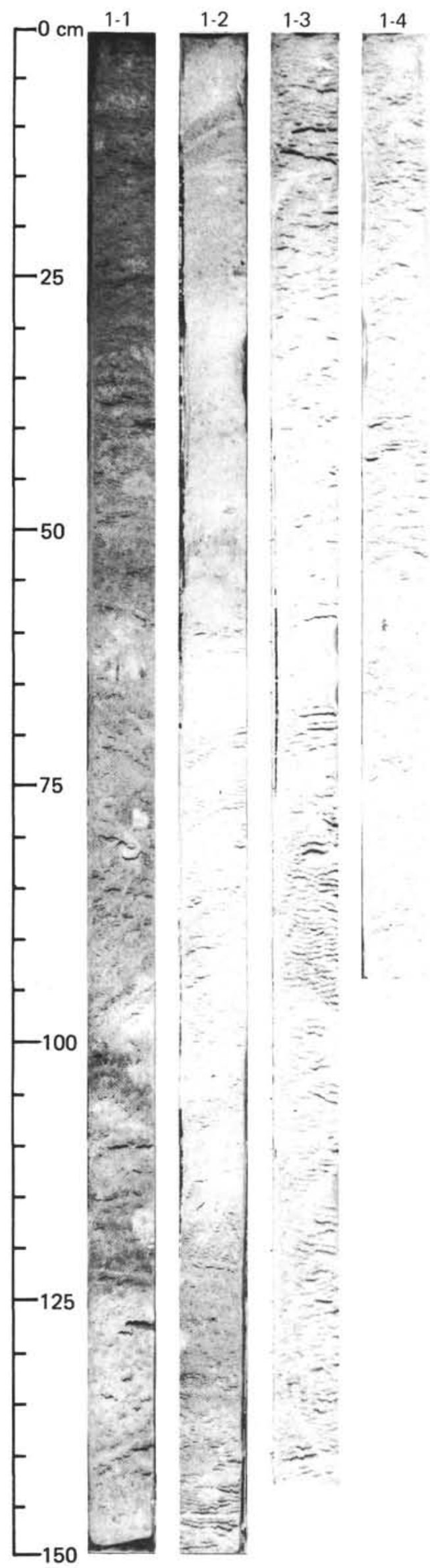

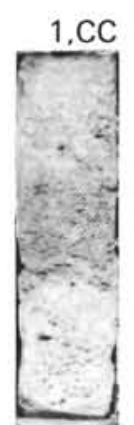
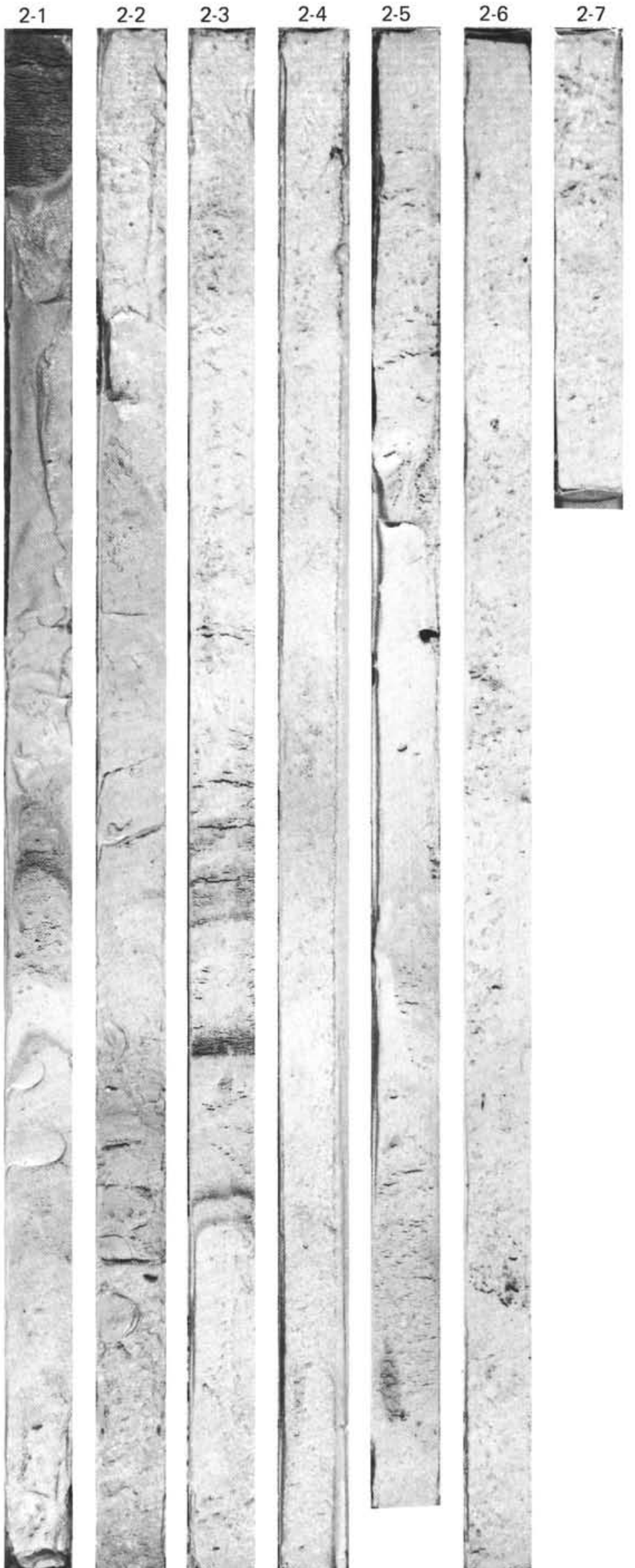
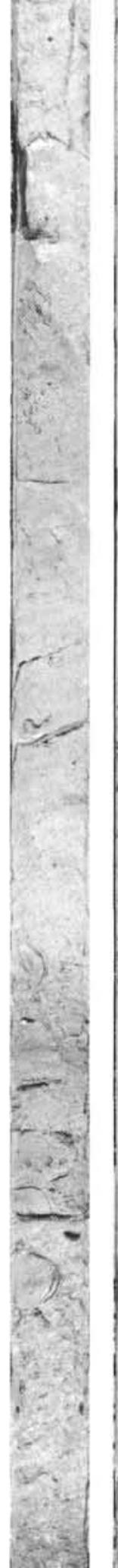
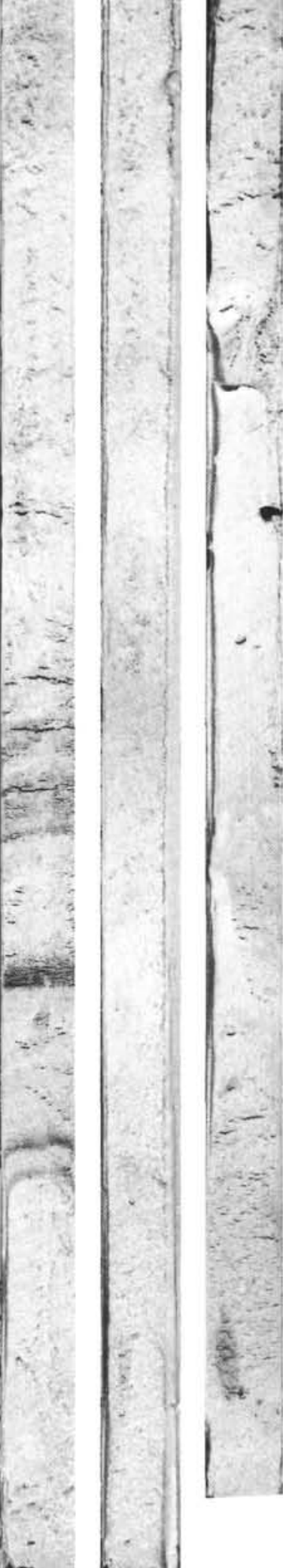
SITE 588 (HOLE 588)

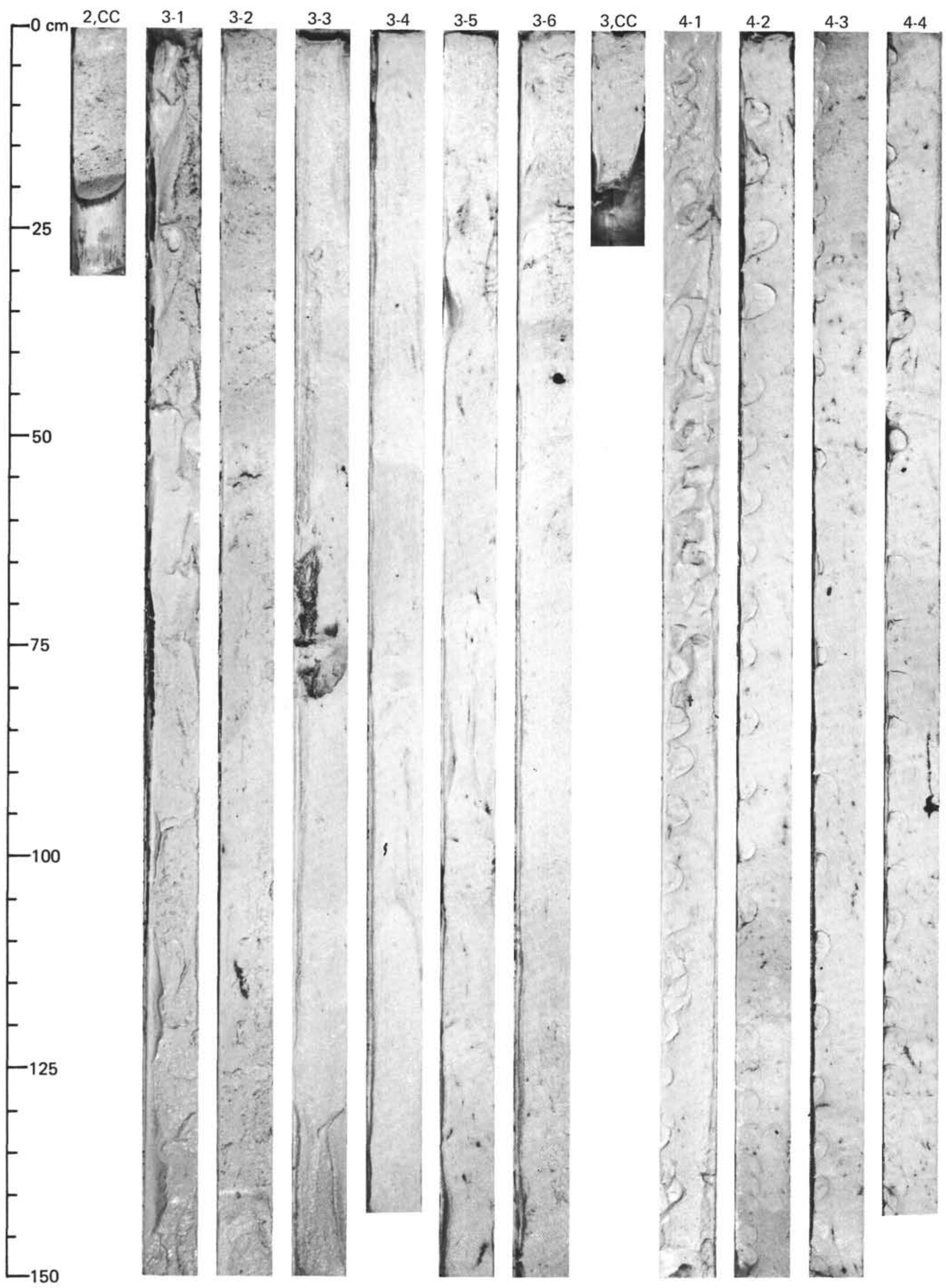




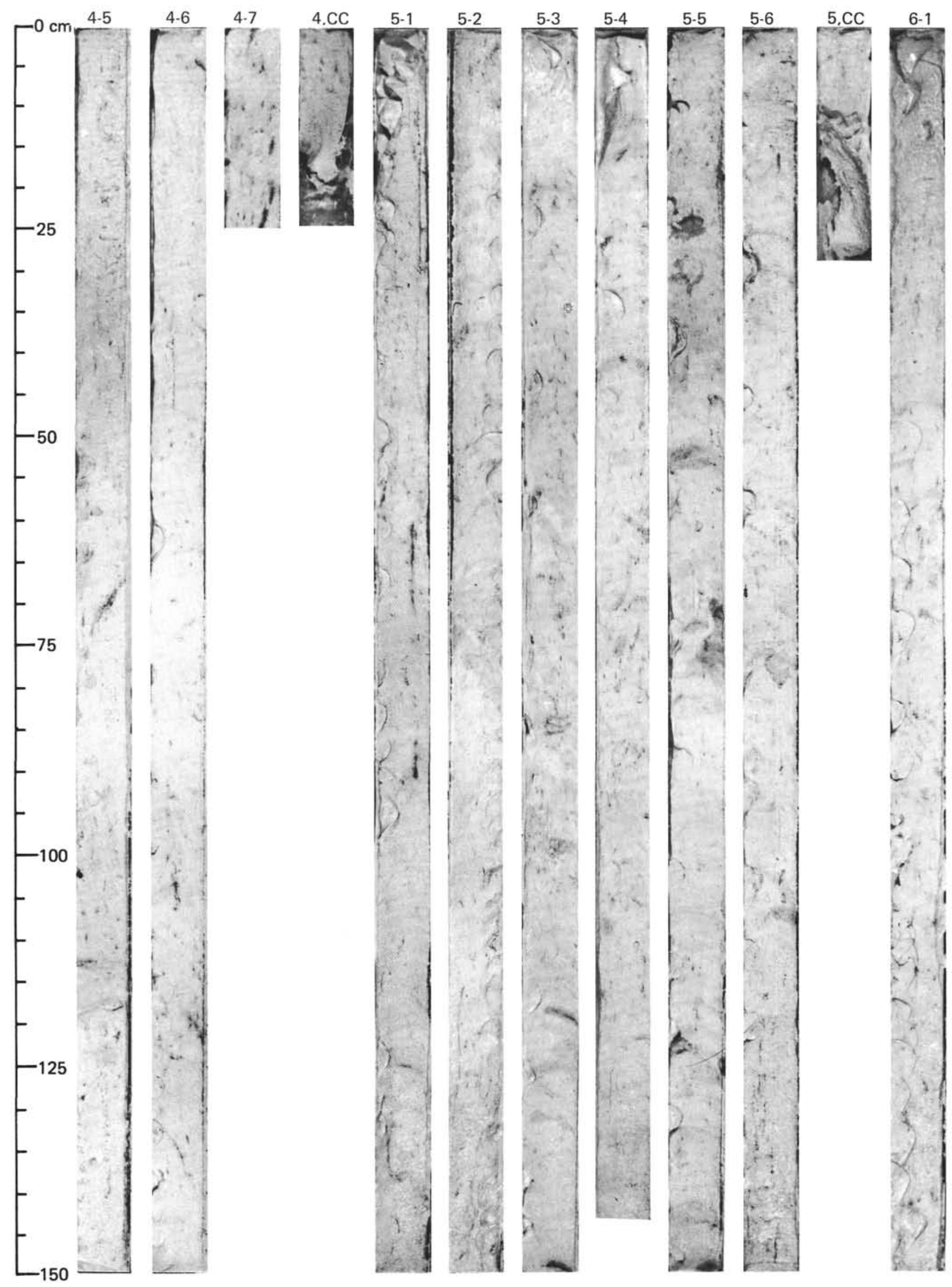




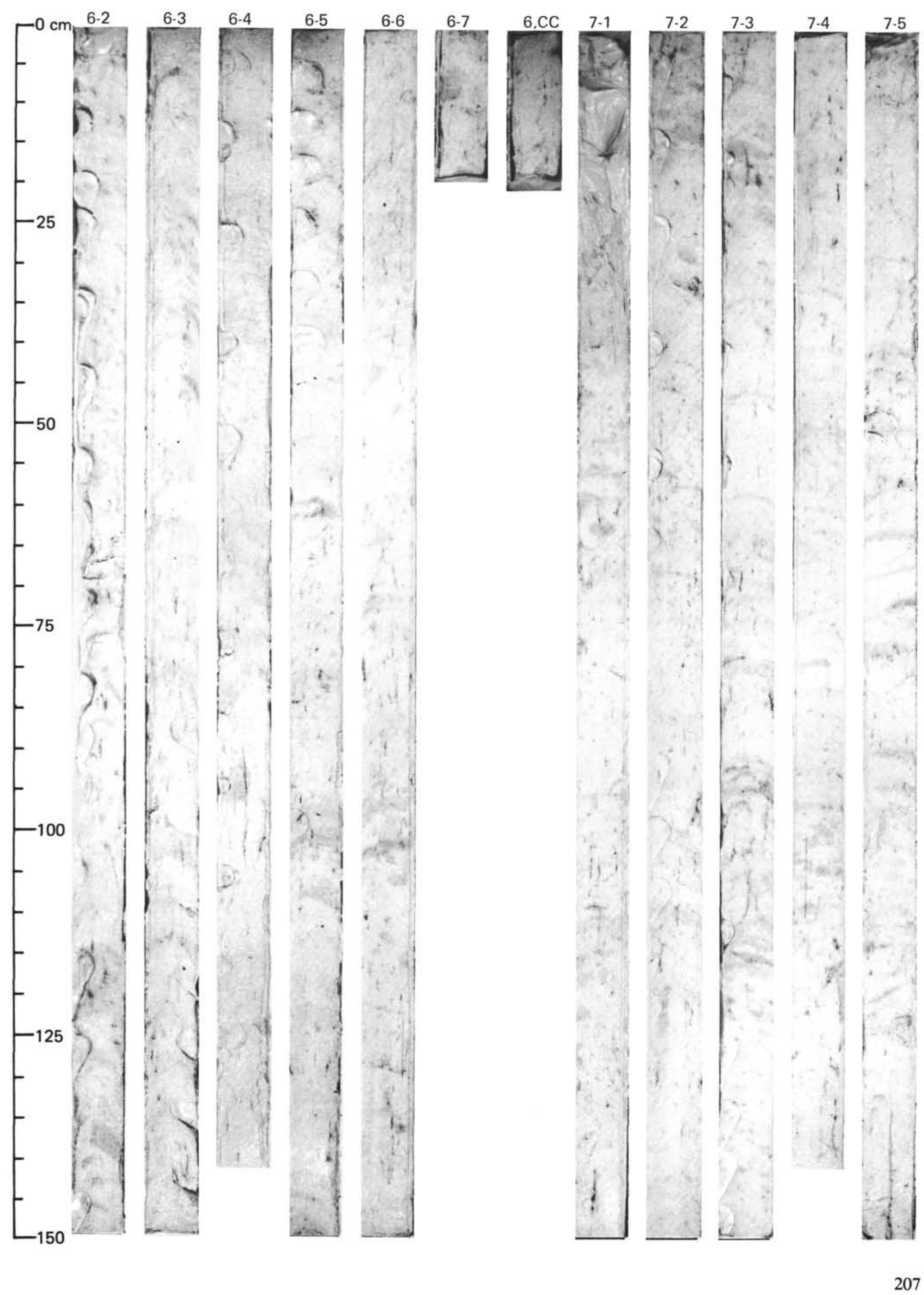




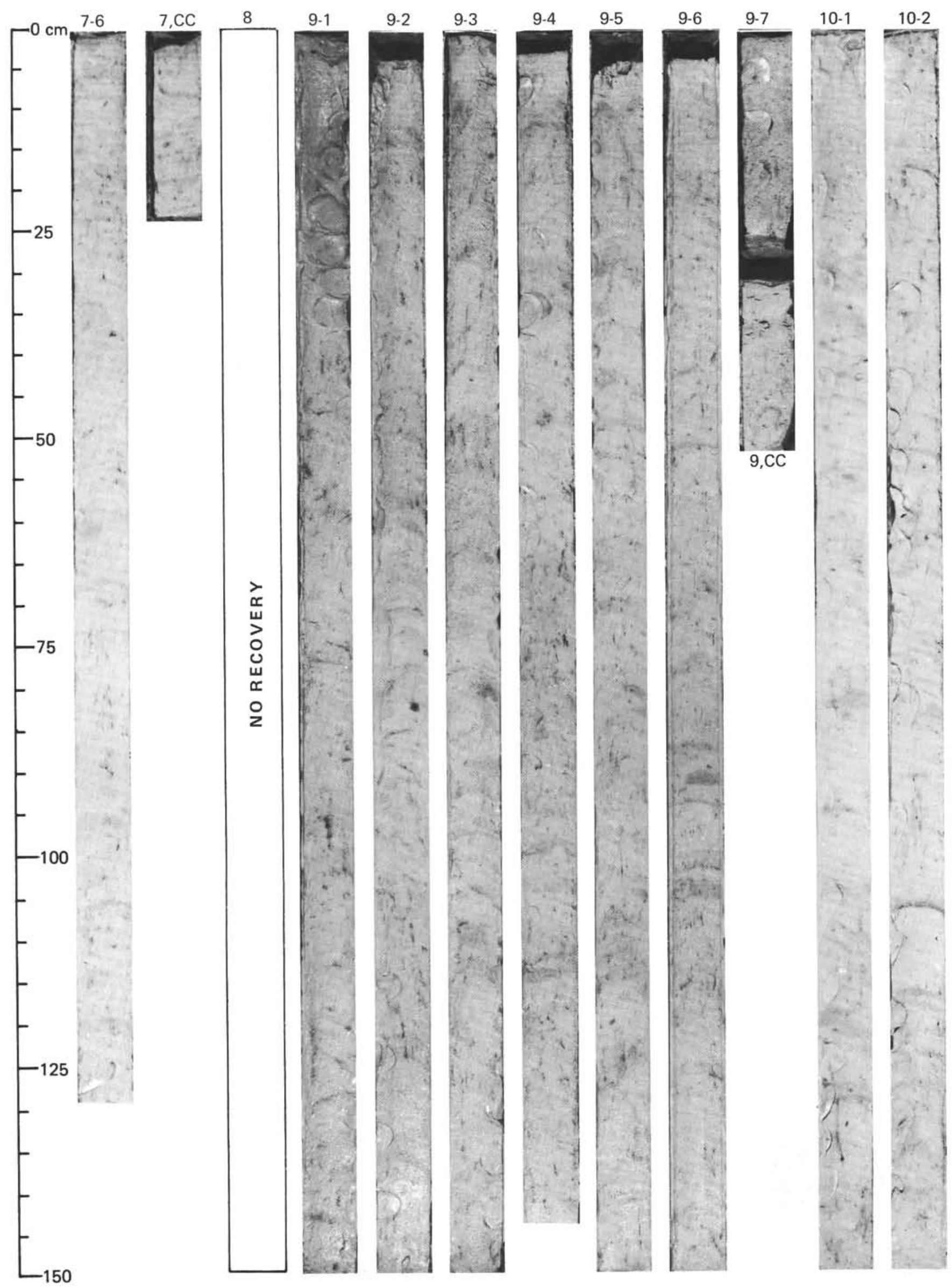




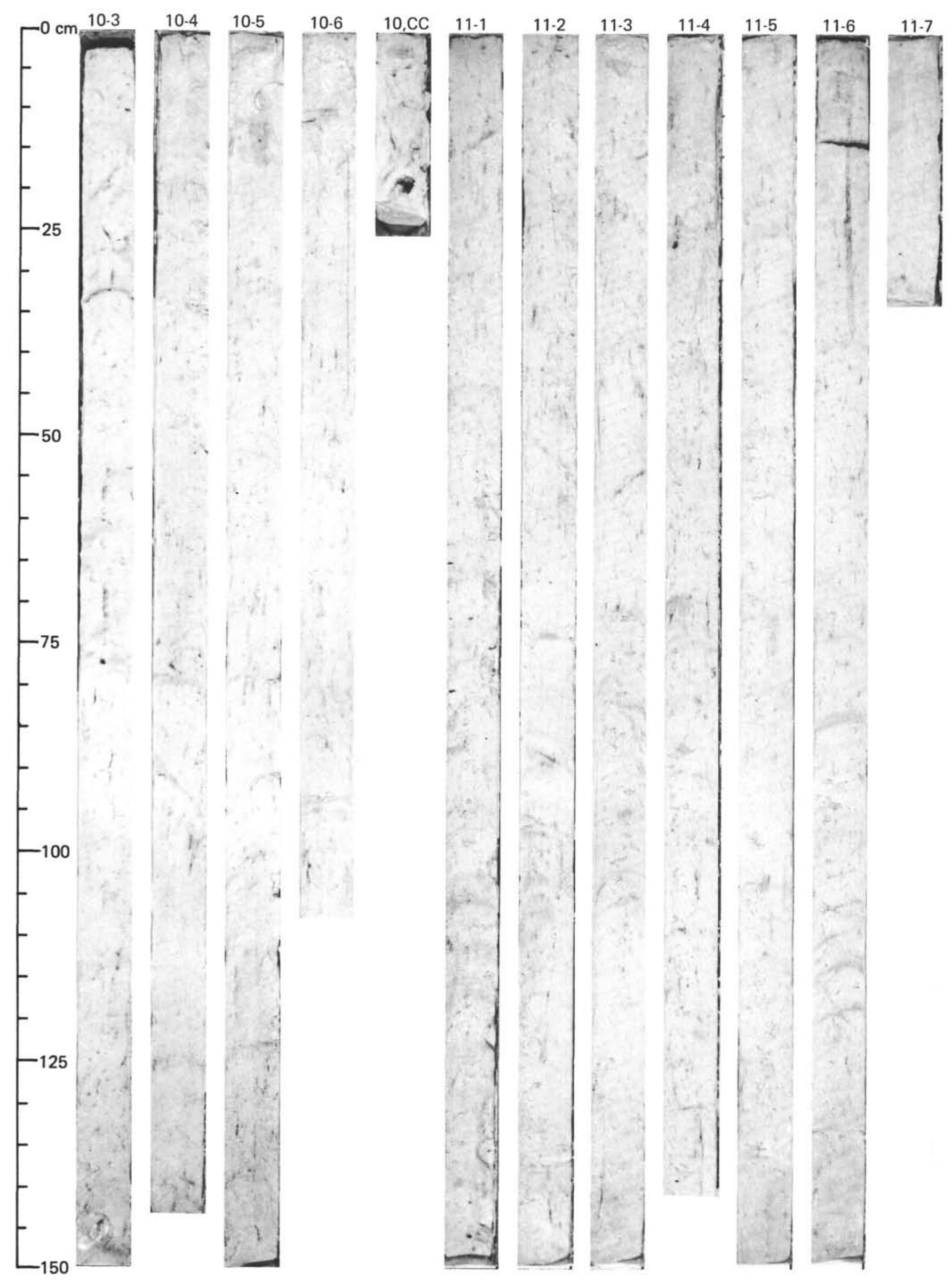




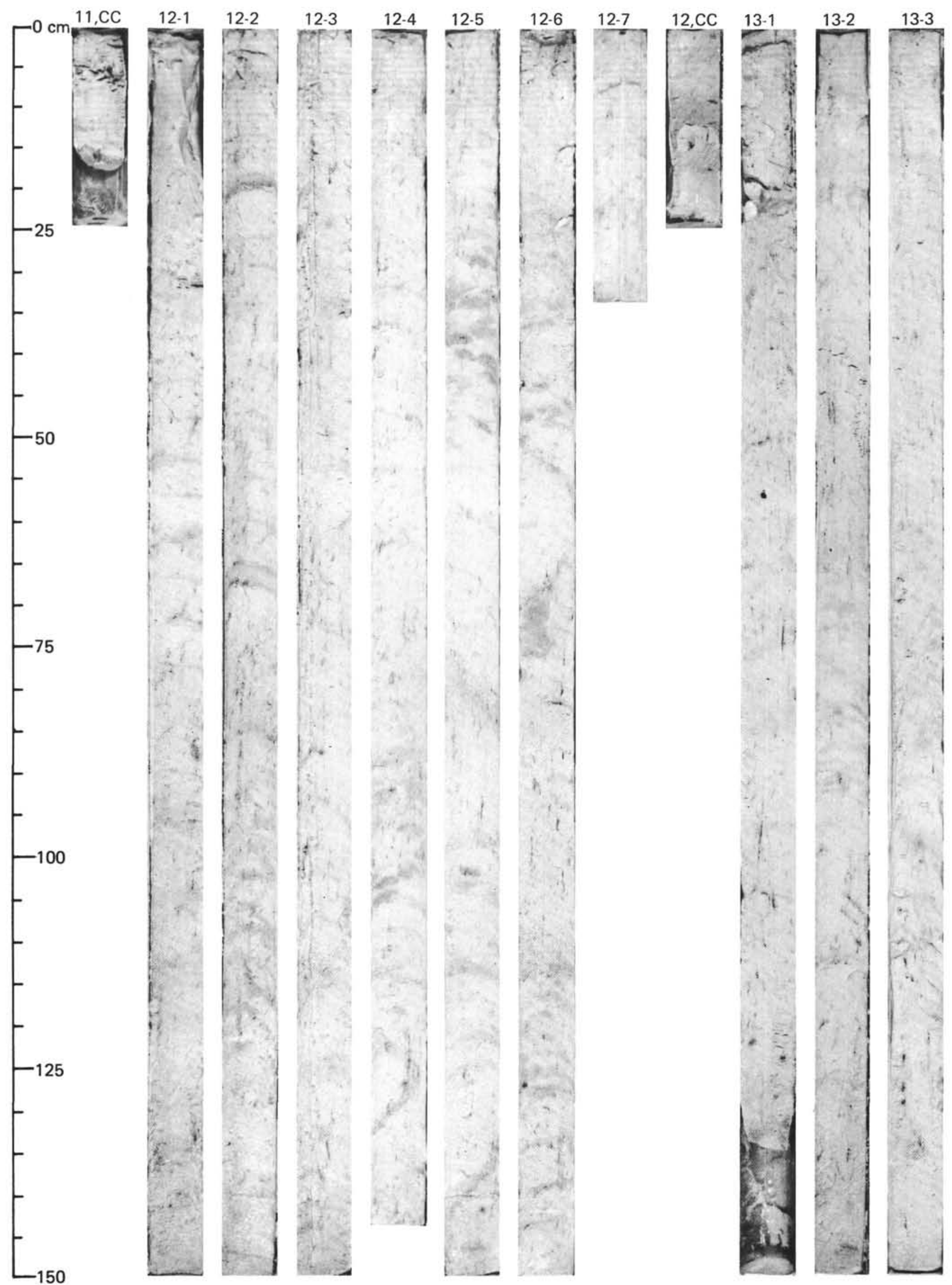




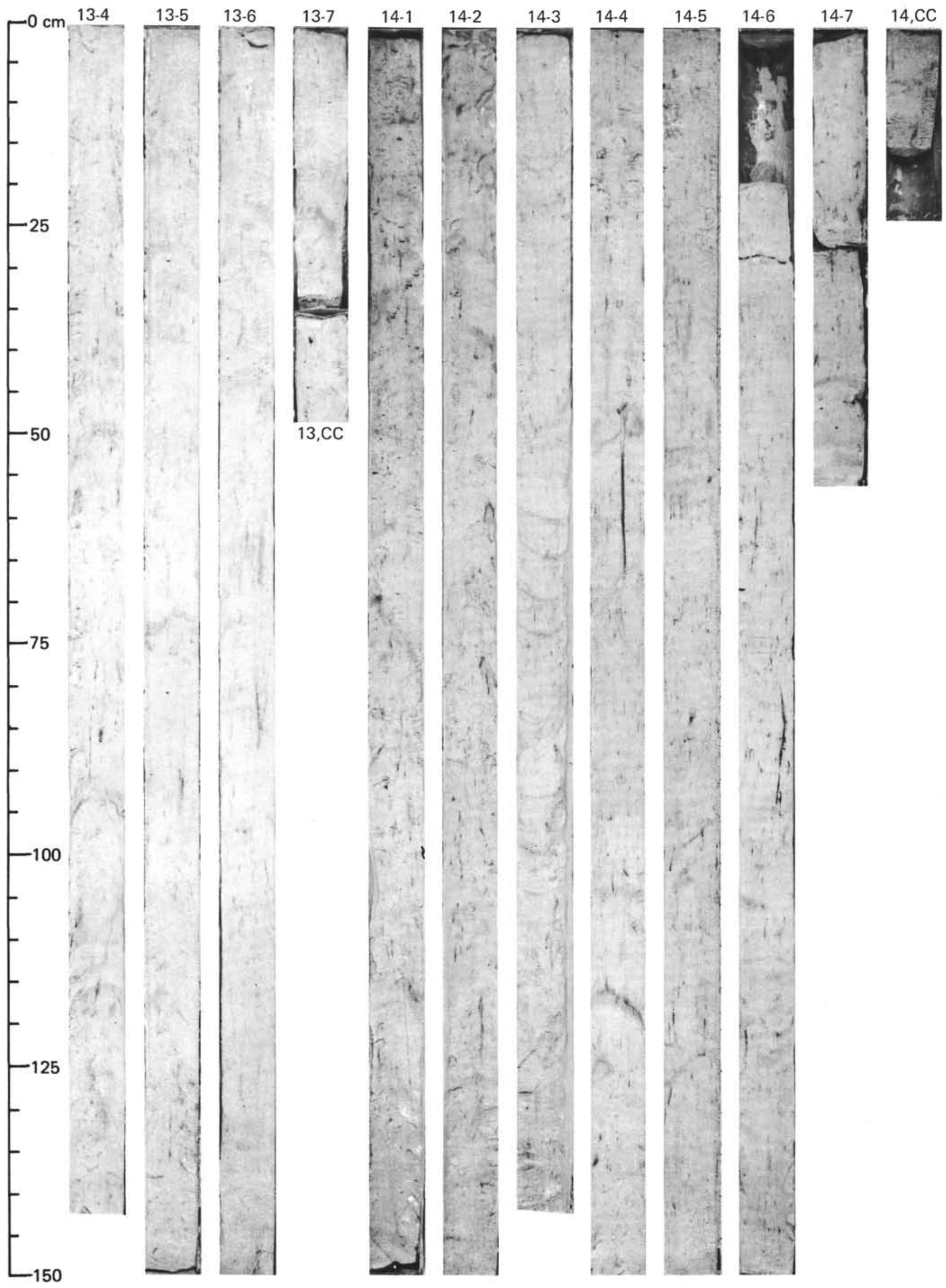


SITE 588 (HOLE 588)

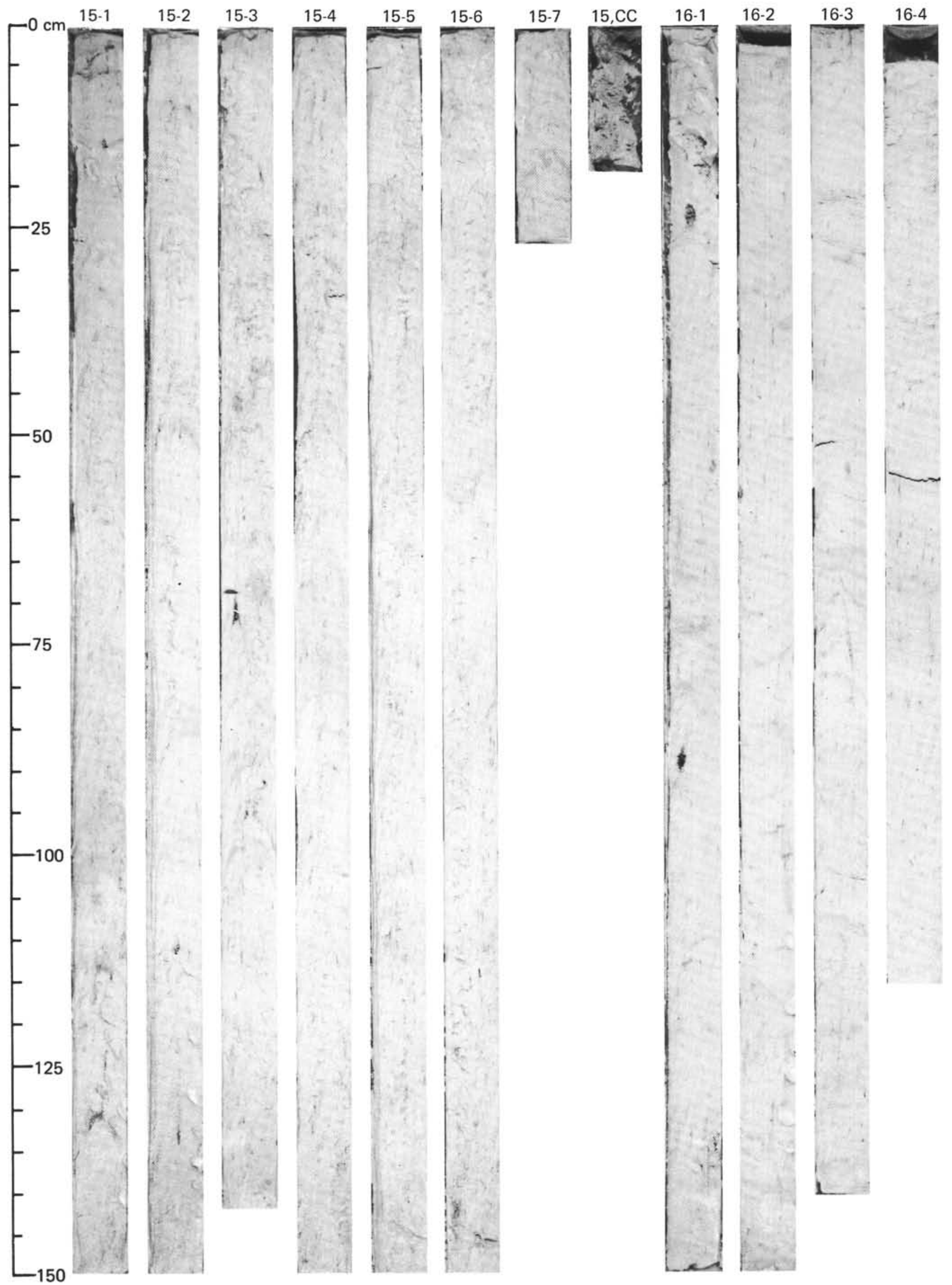




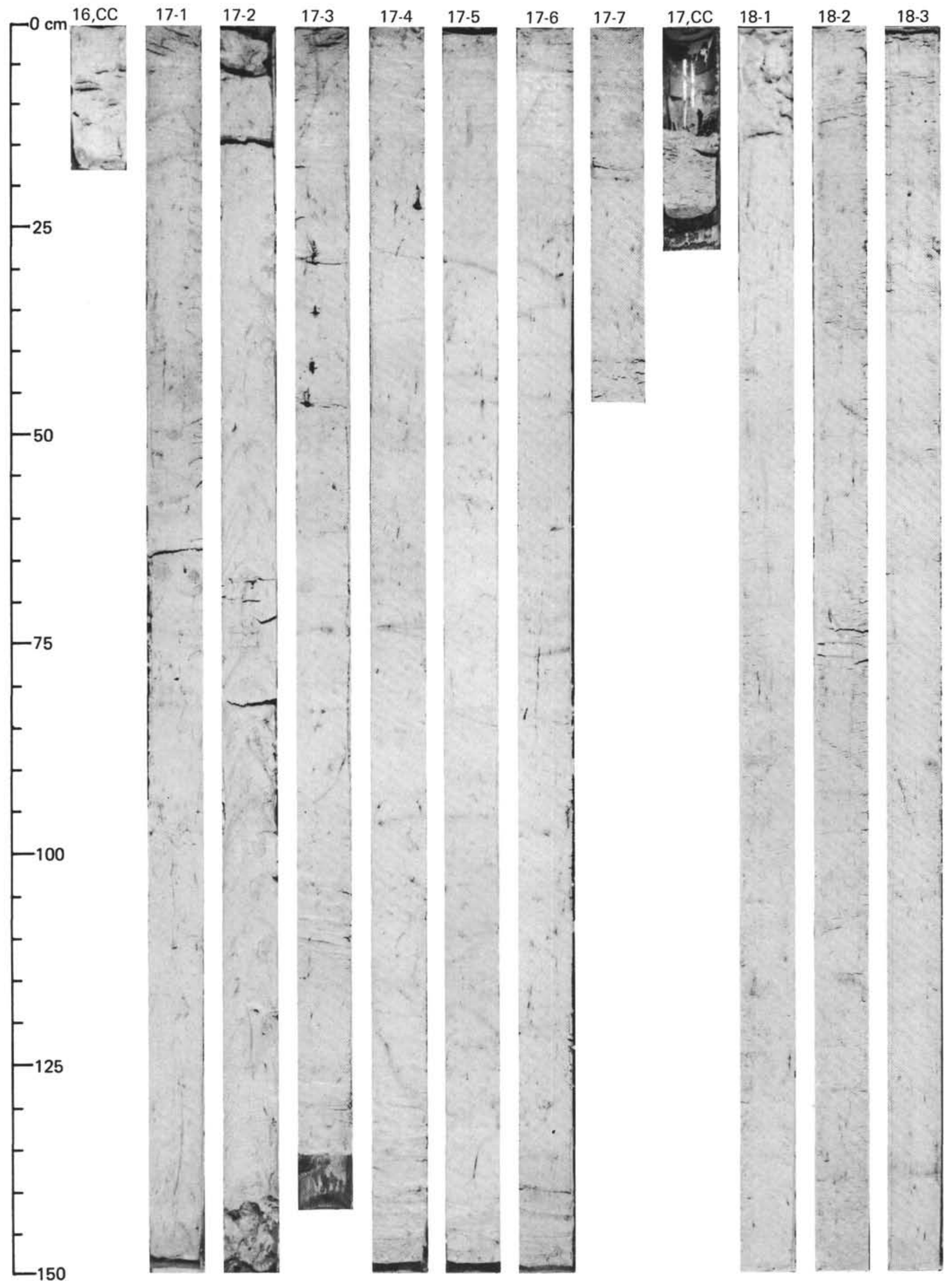




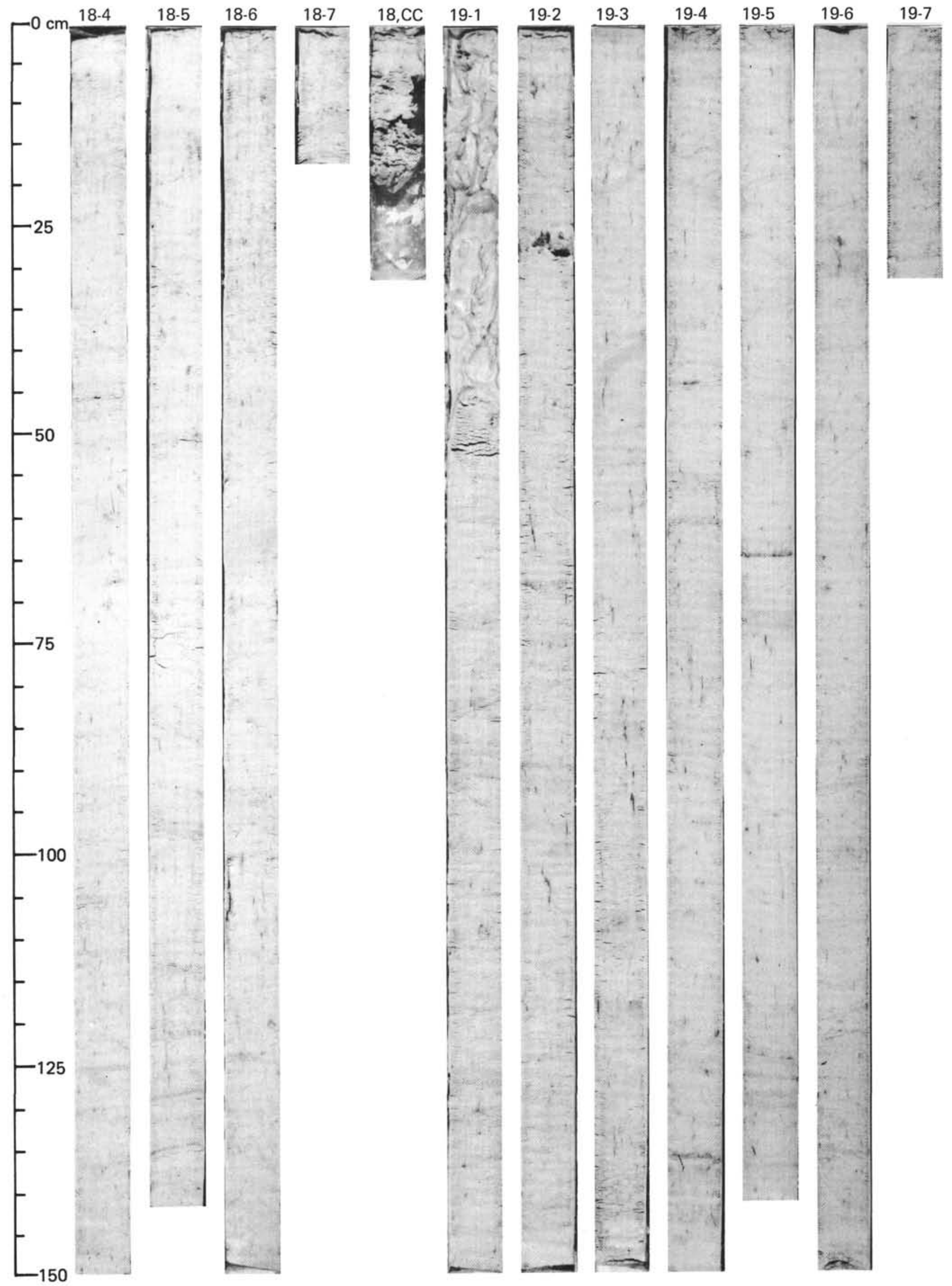




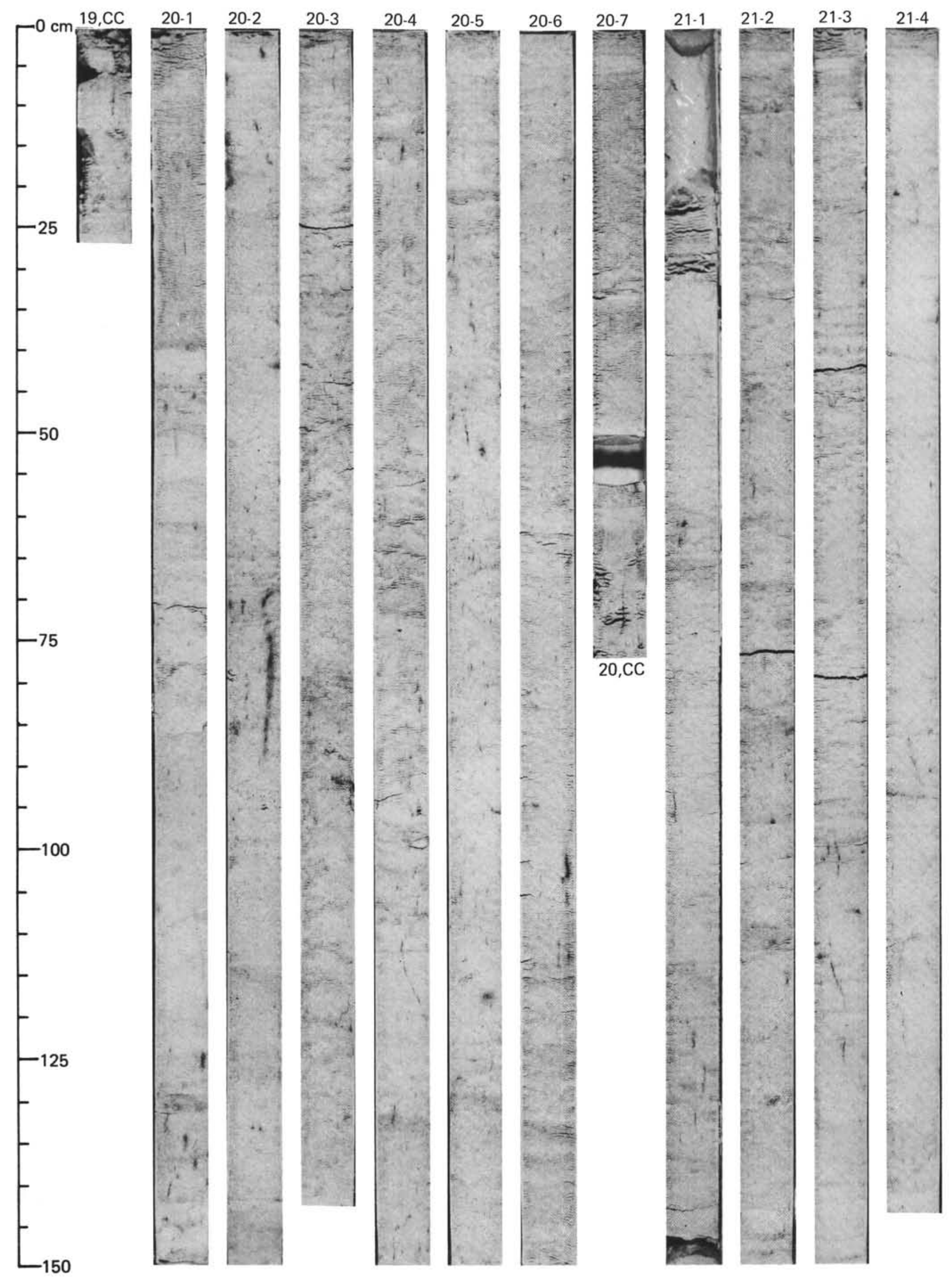




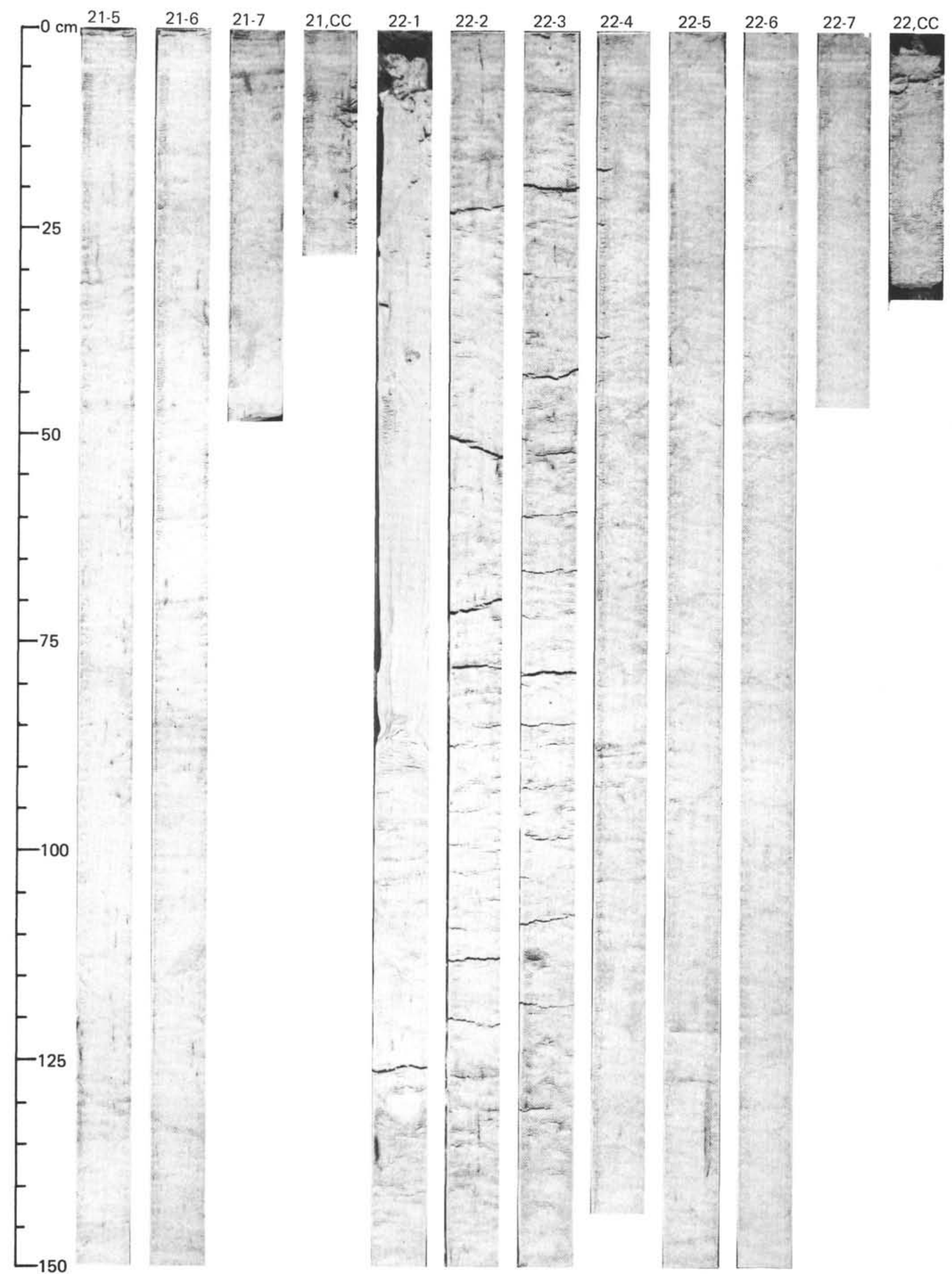




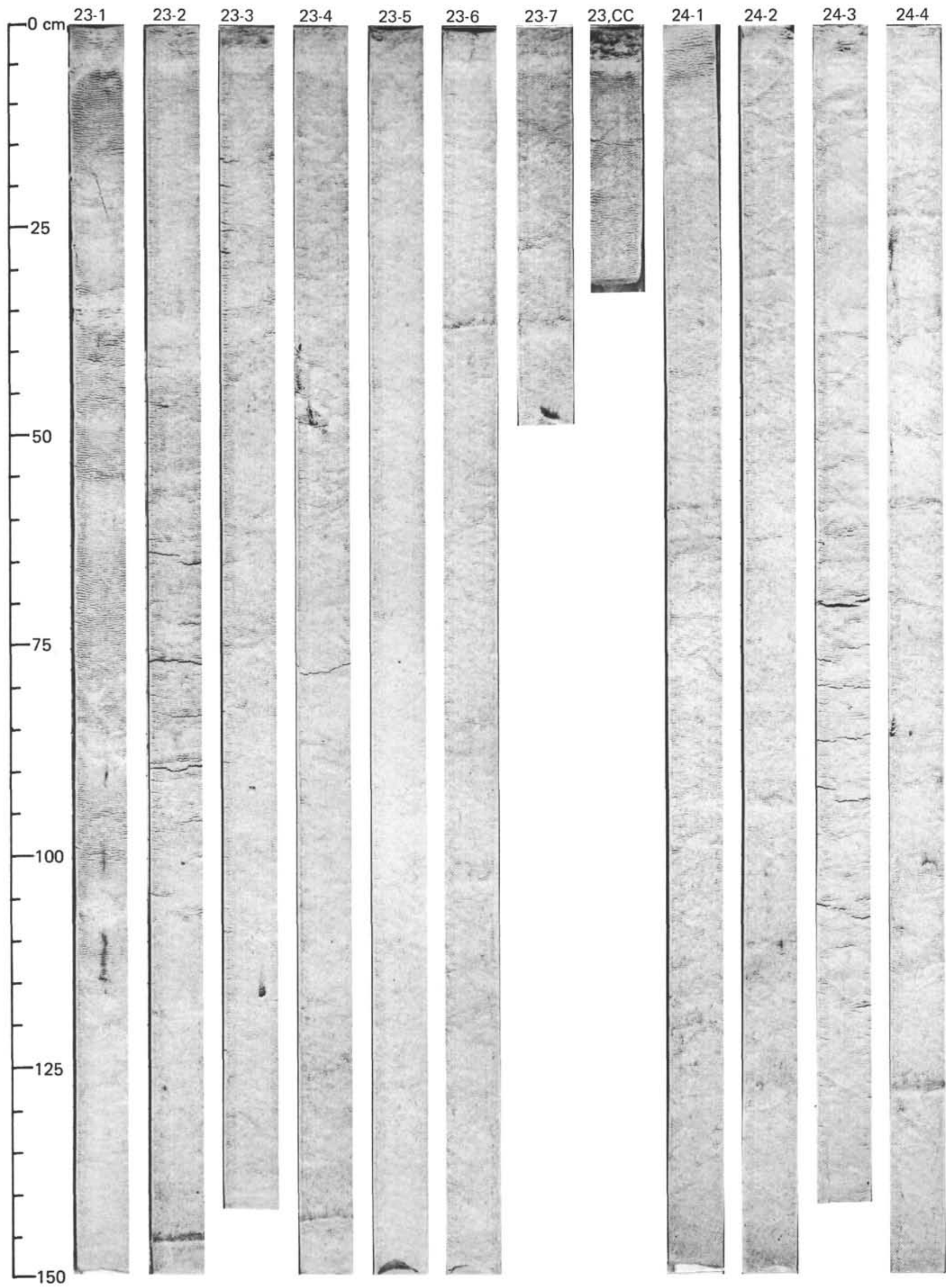




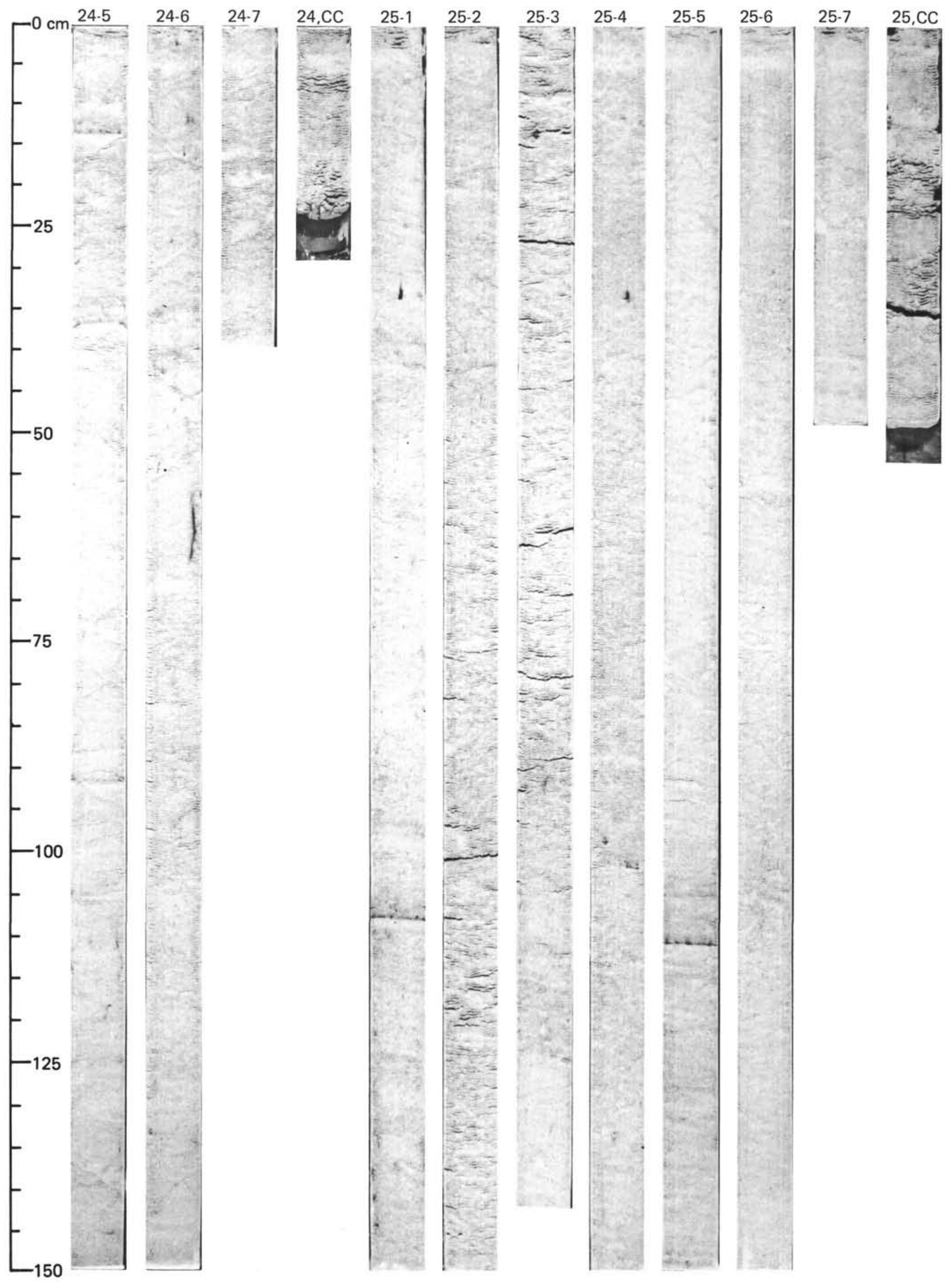



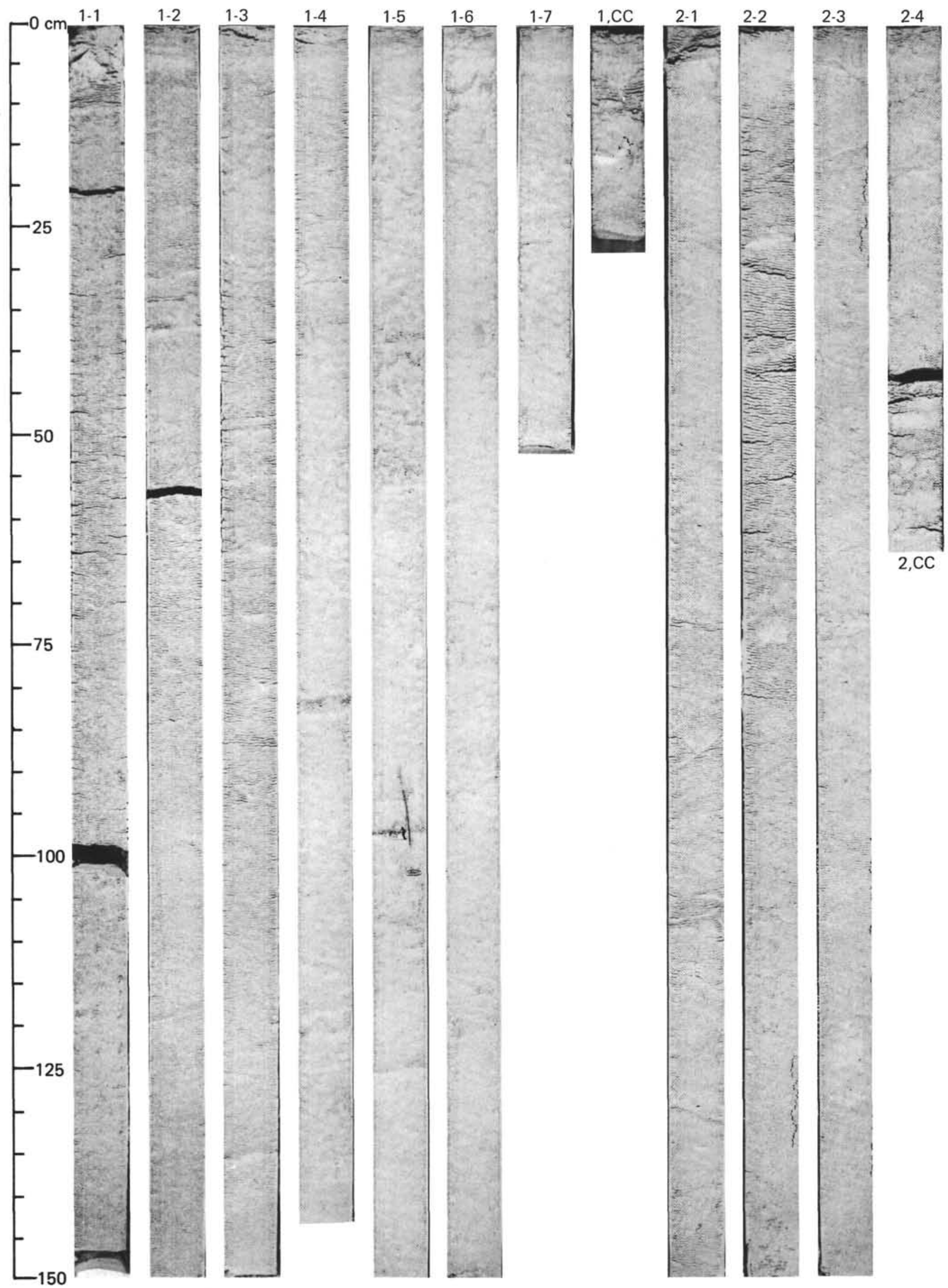


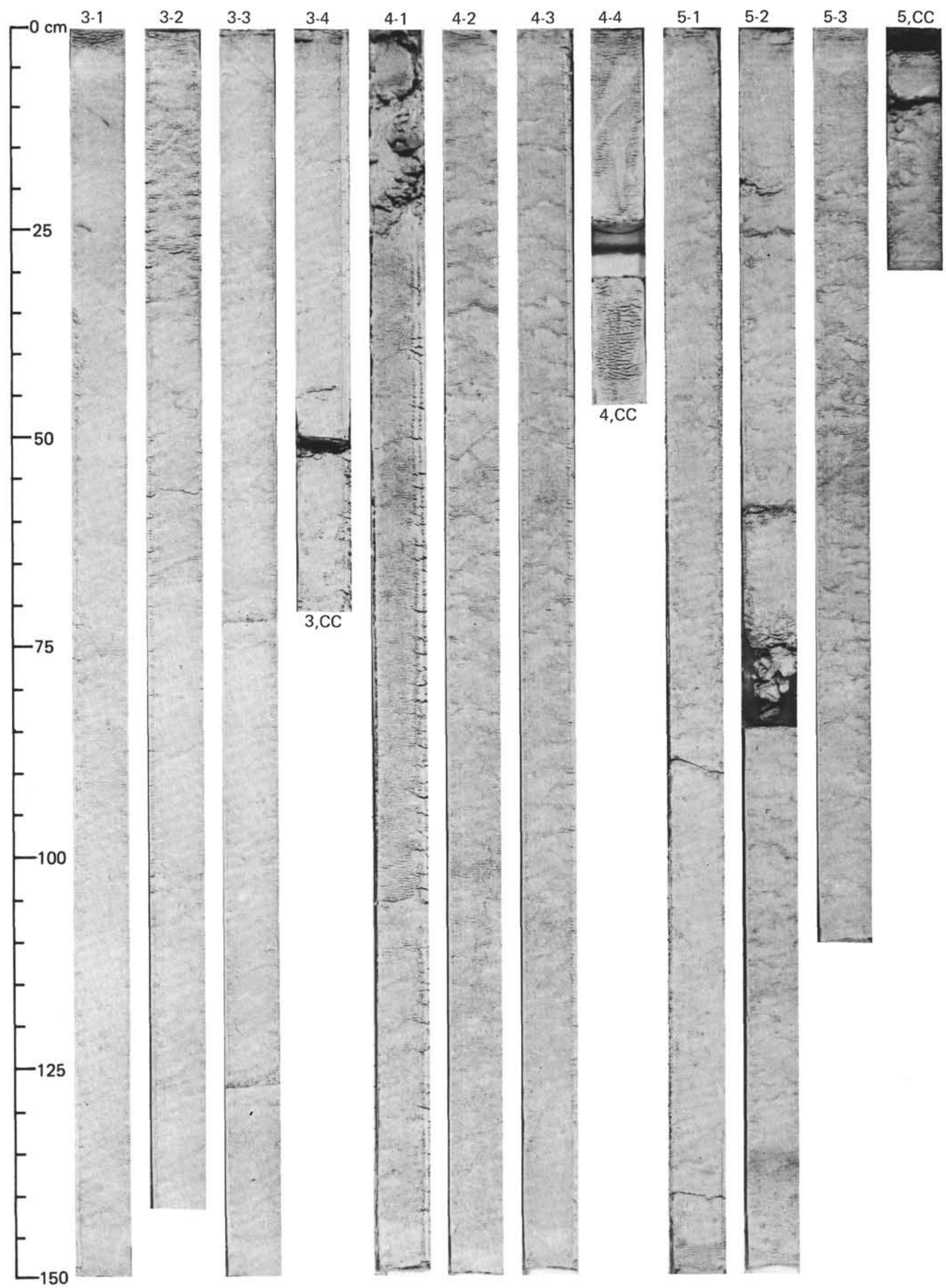


SITE 588 (HOLE 588A)

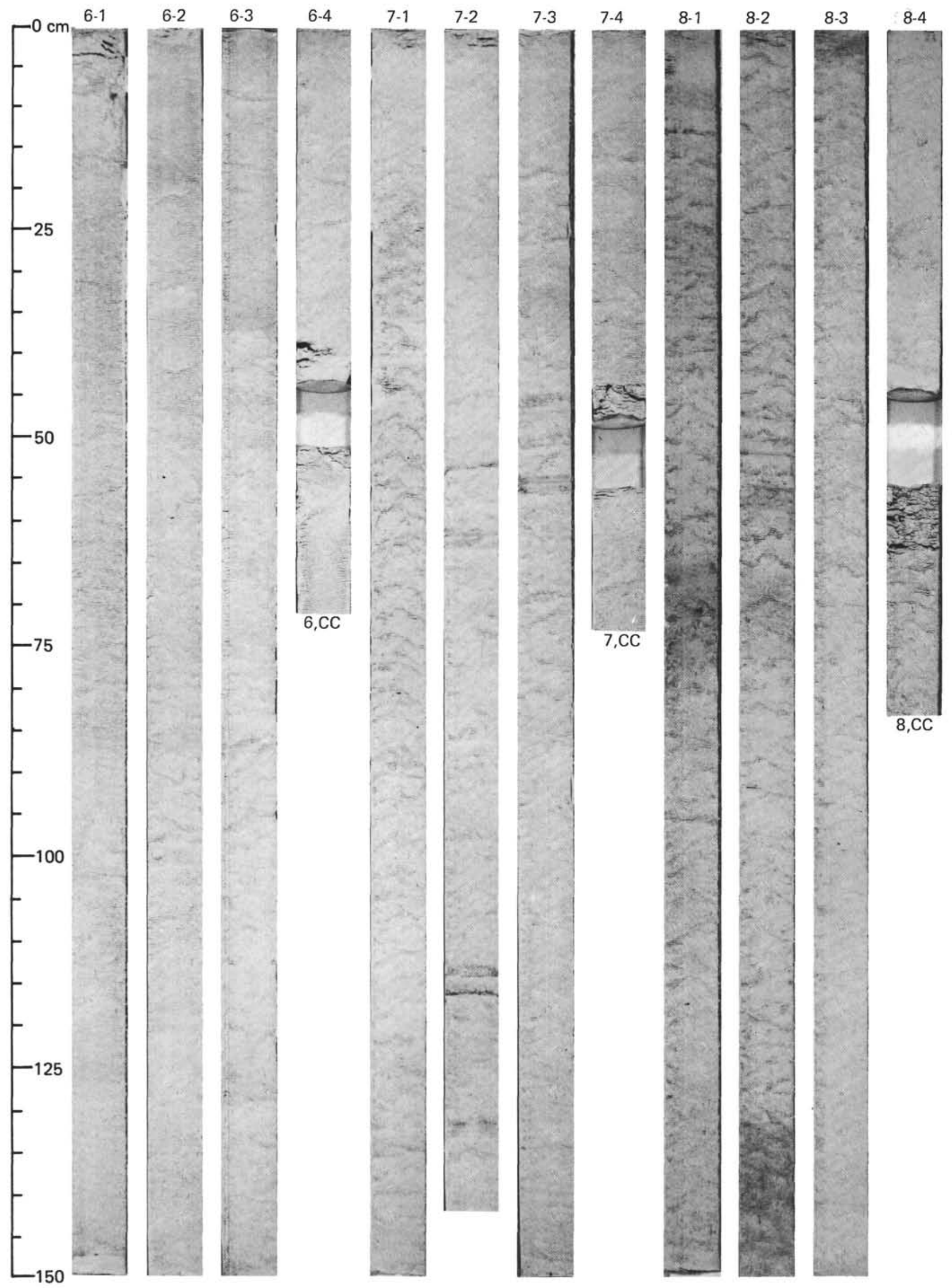




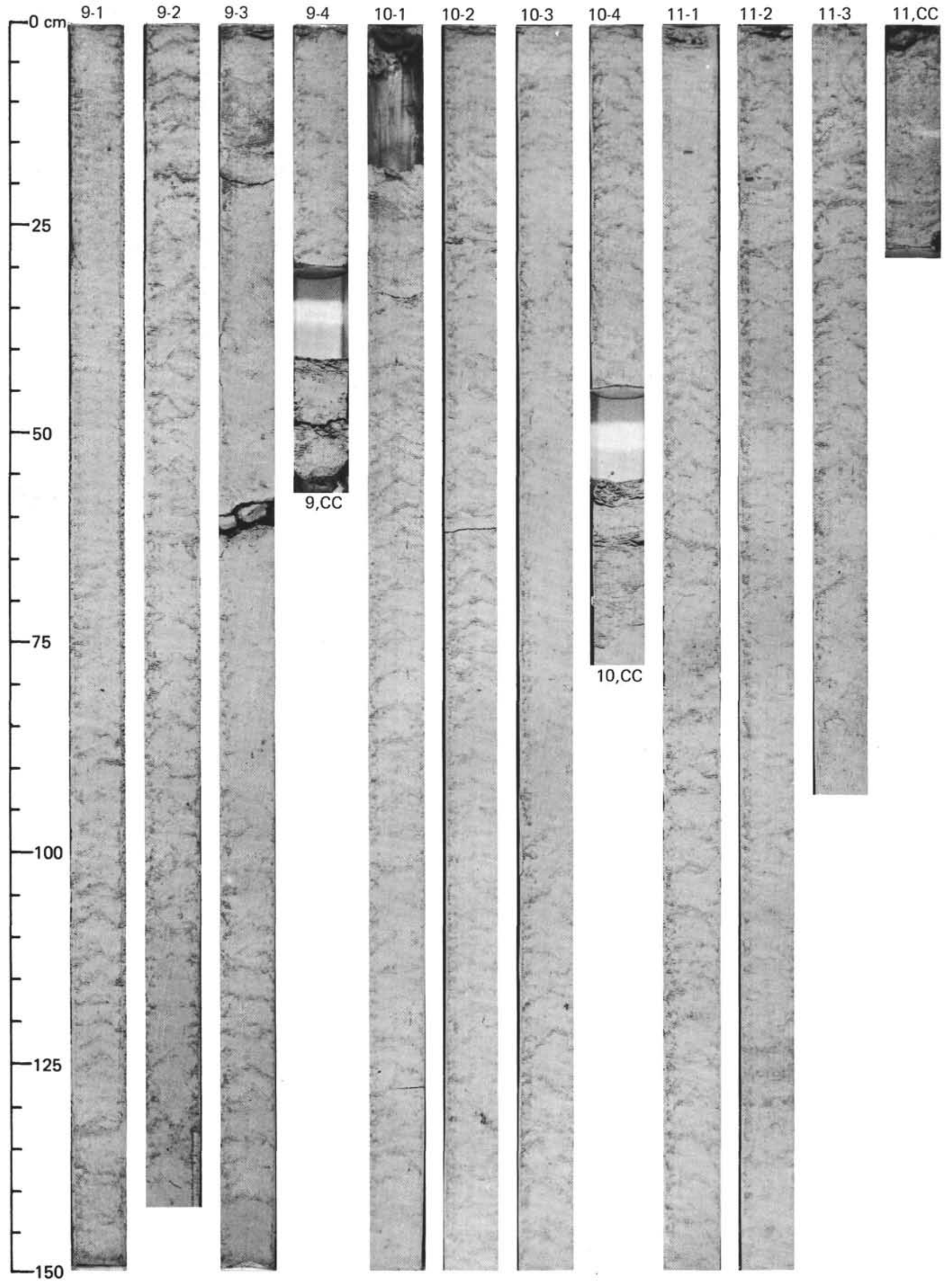




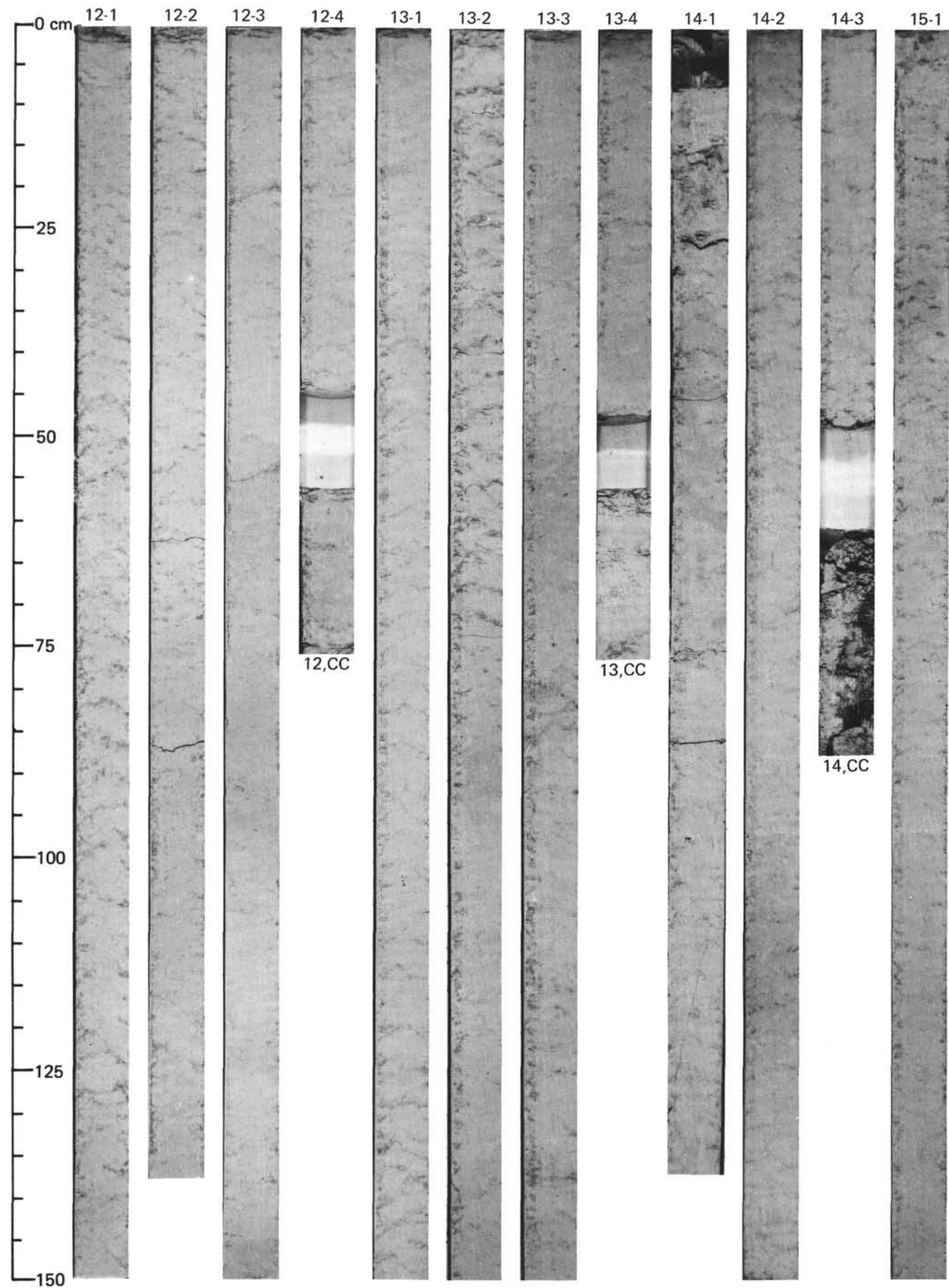




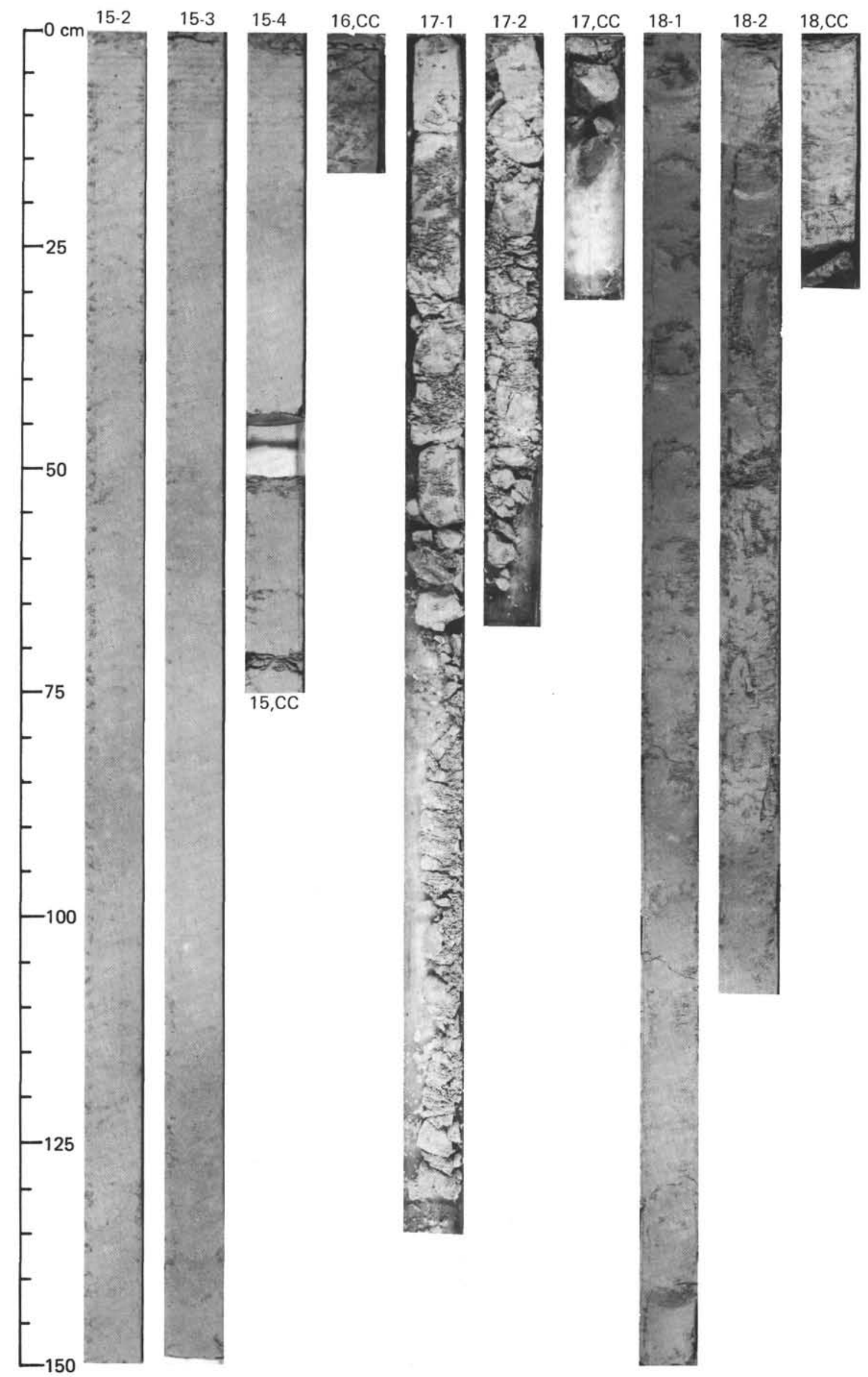


SITE 588 (HOLE 588B)

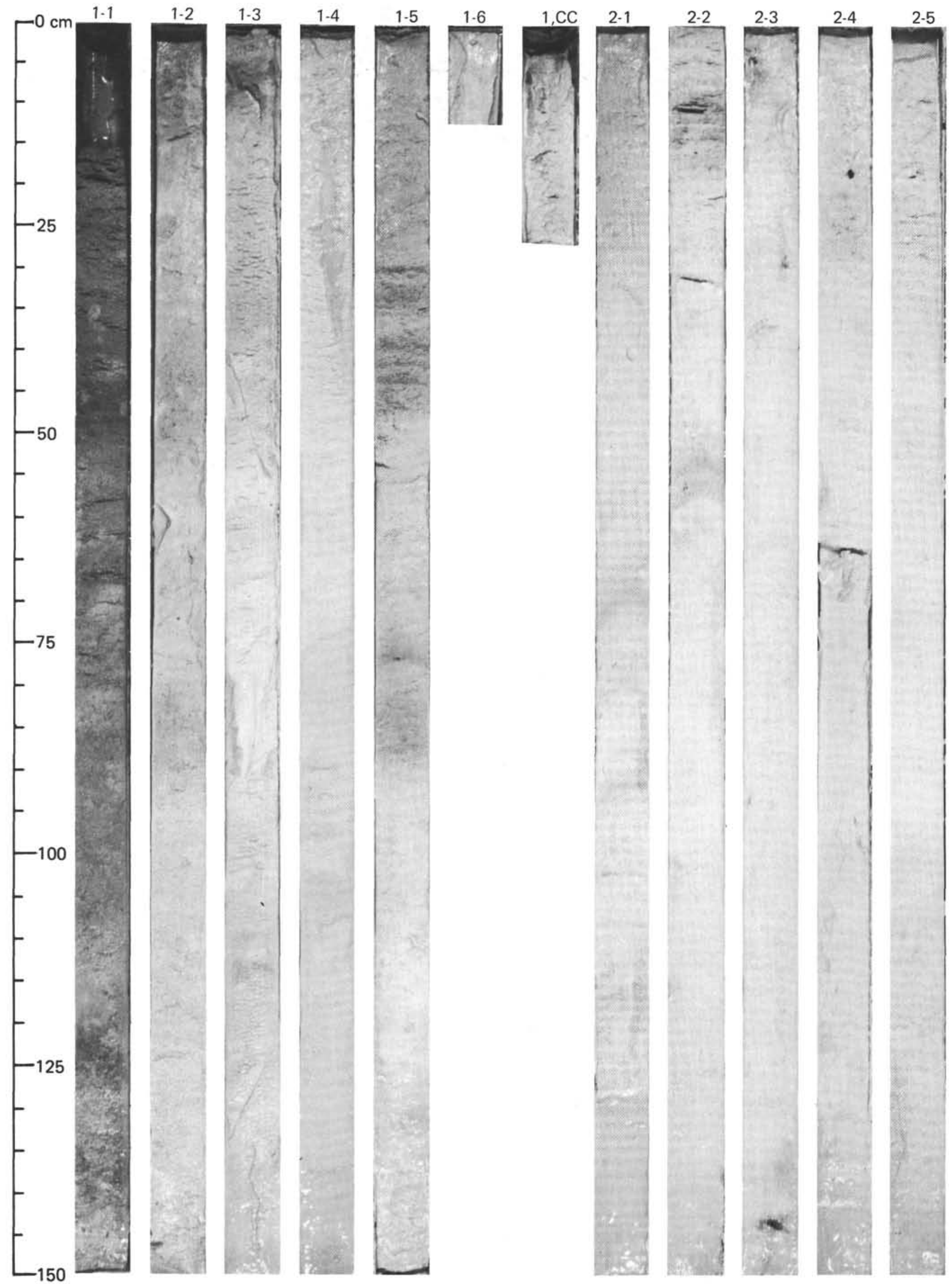




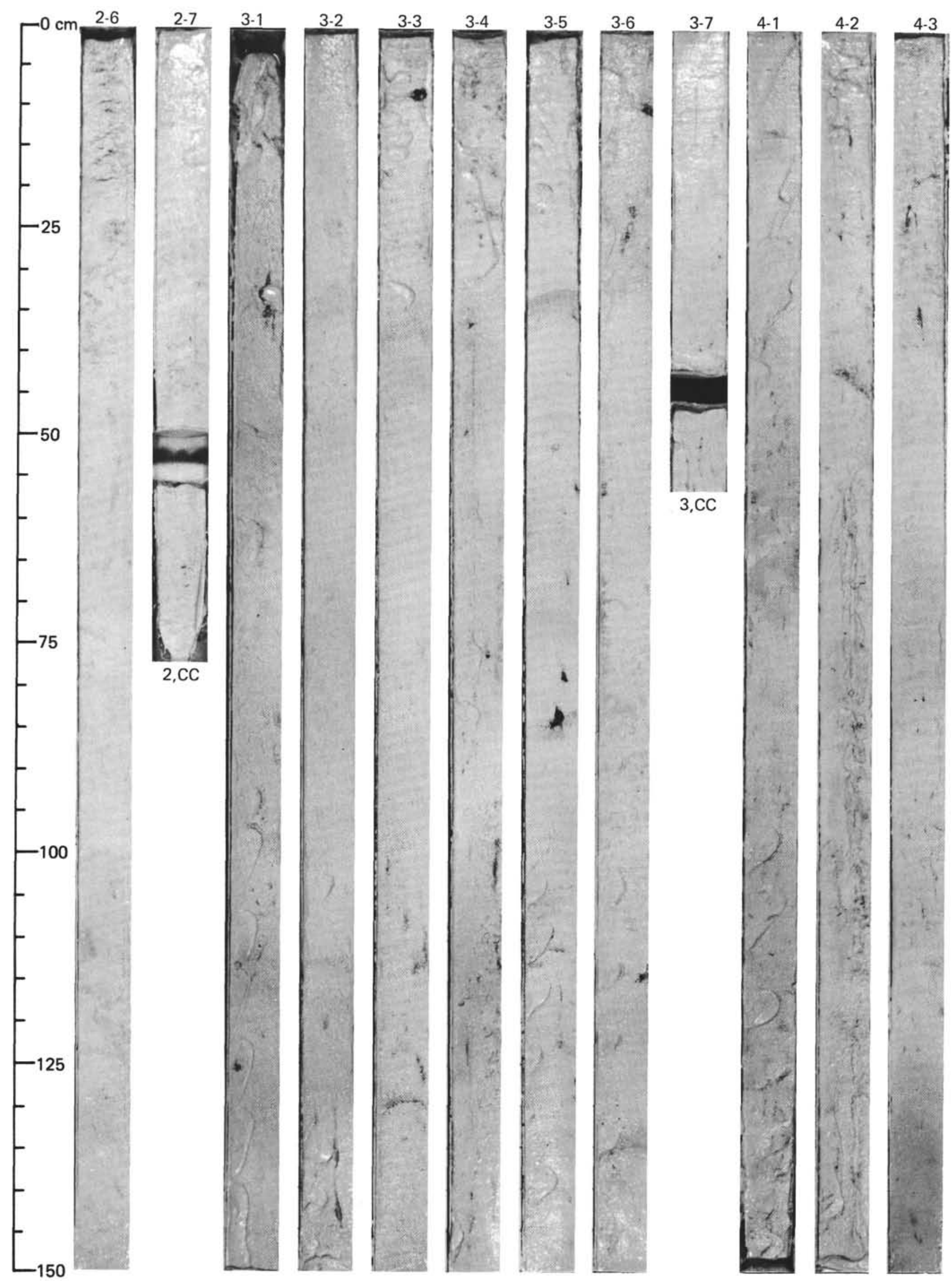




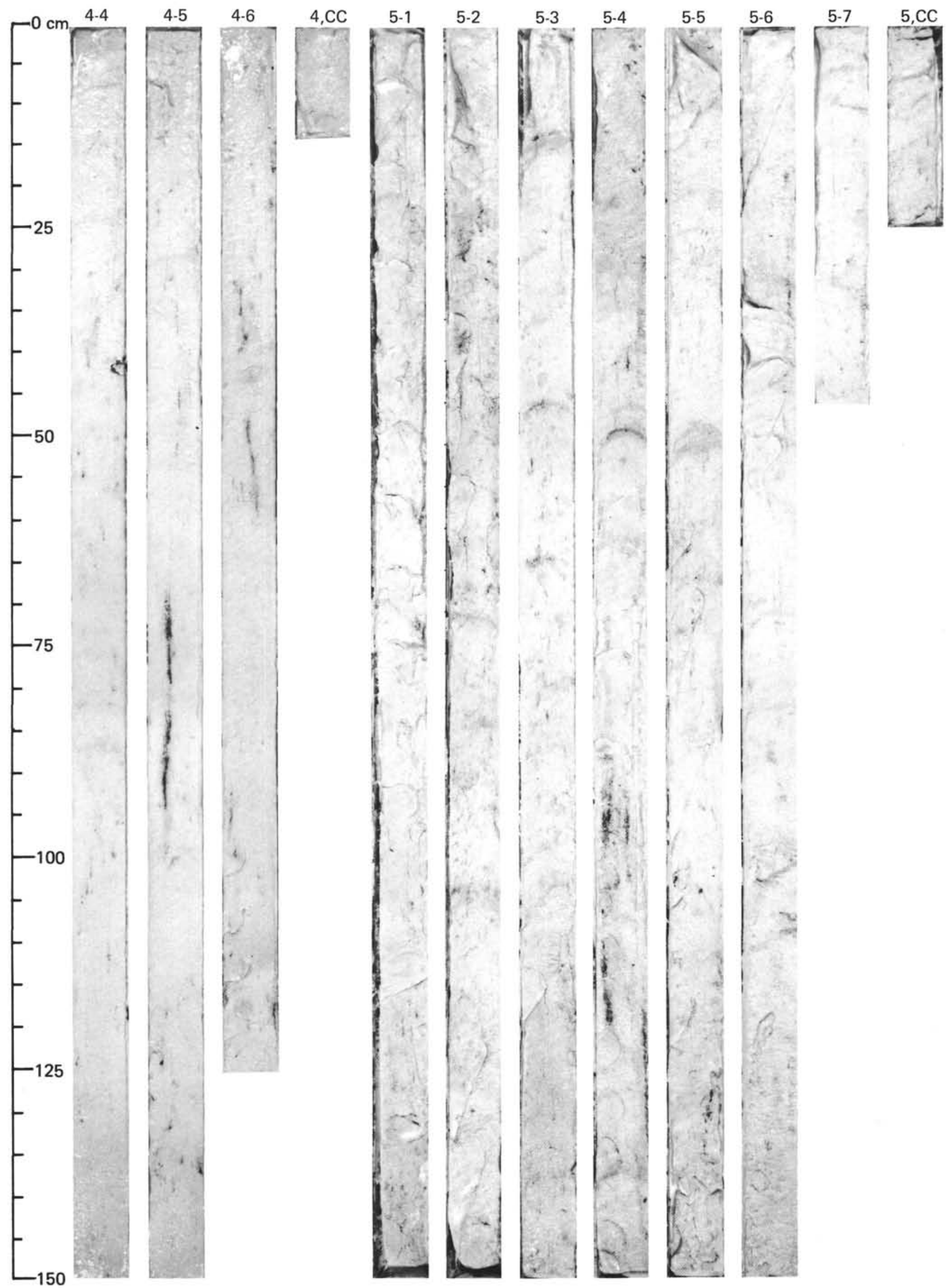




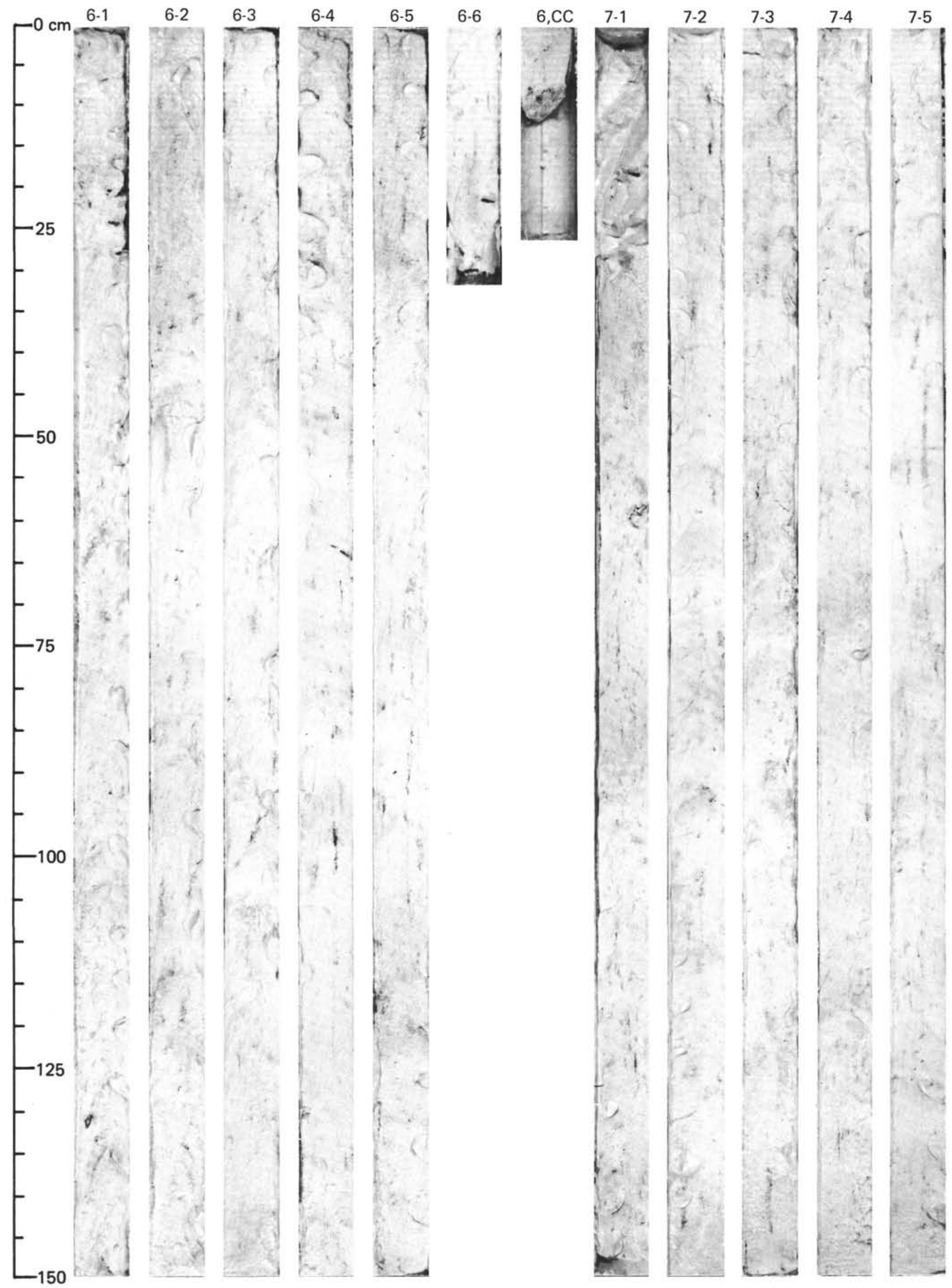




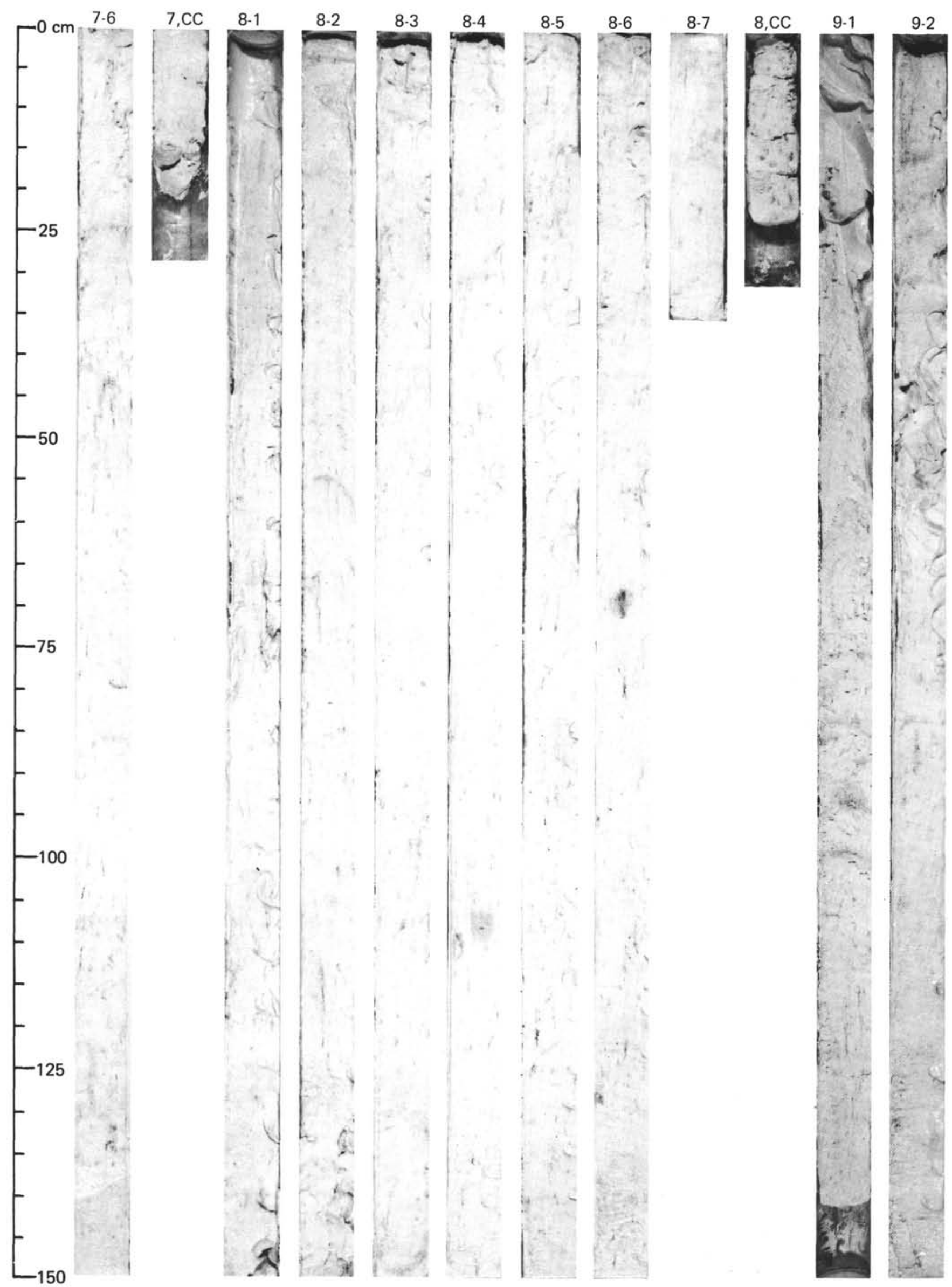




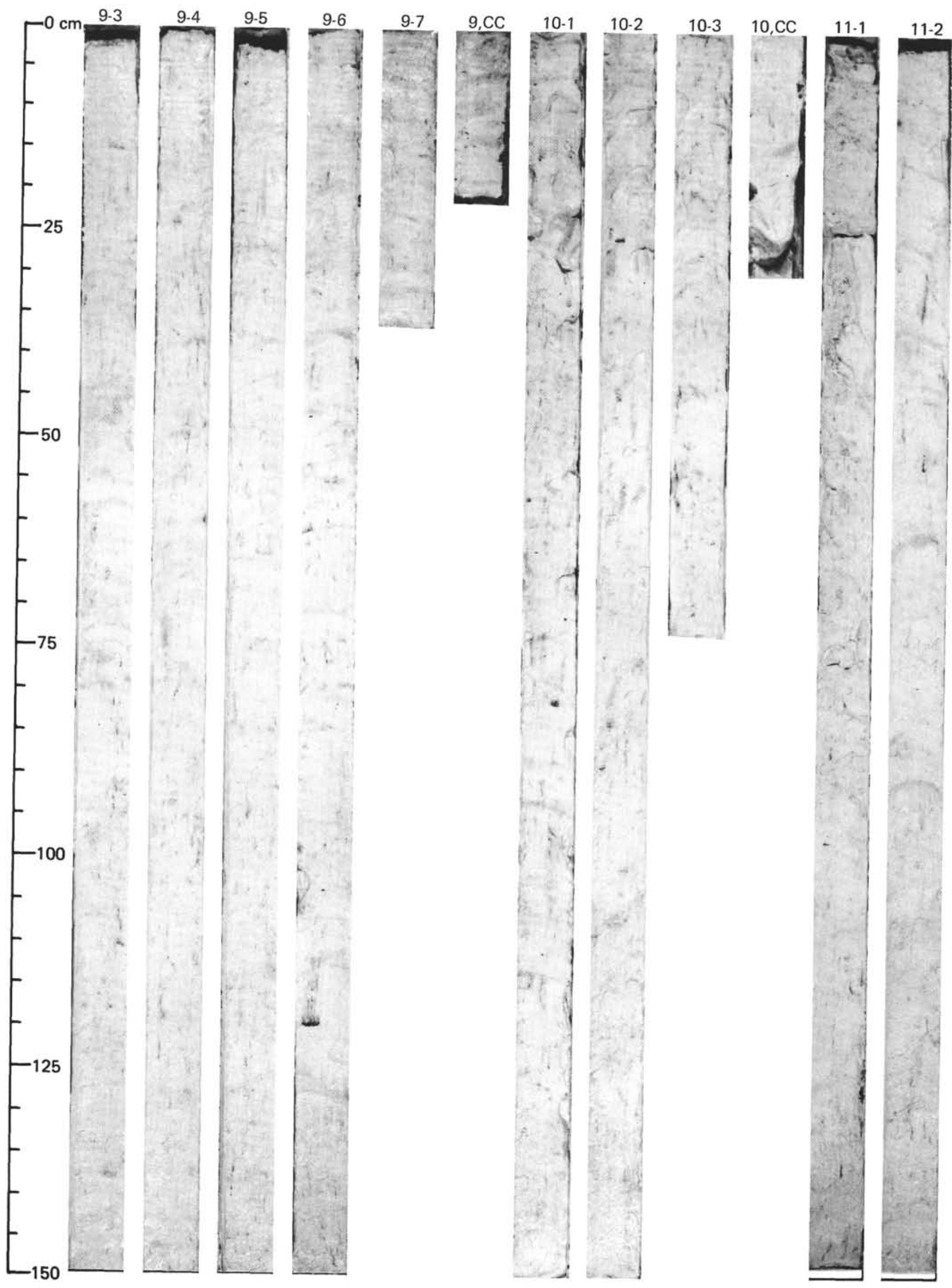


SITE 588 (HOLE 588B)

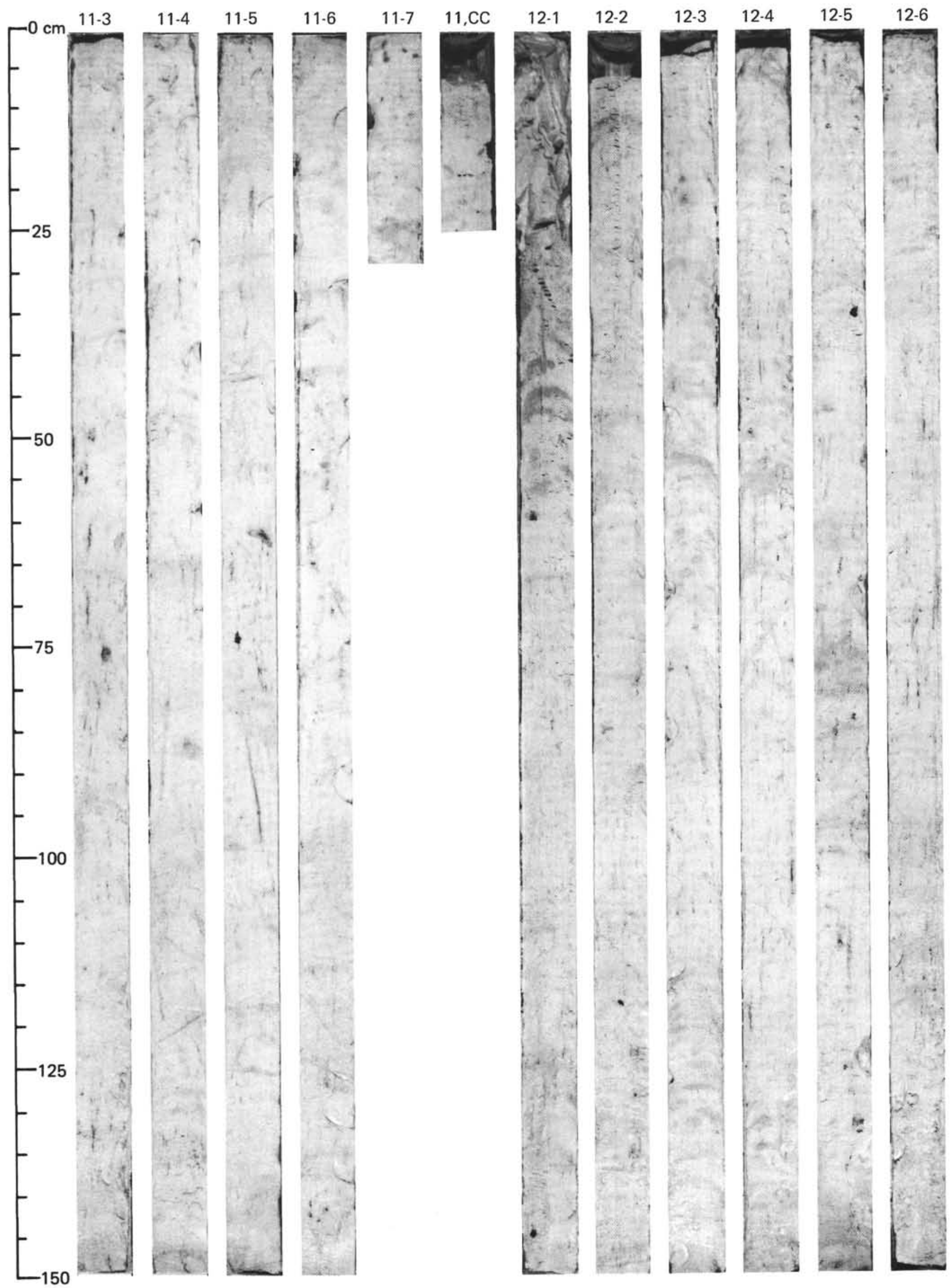


SITE 588 (HOLE 588B)

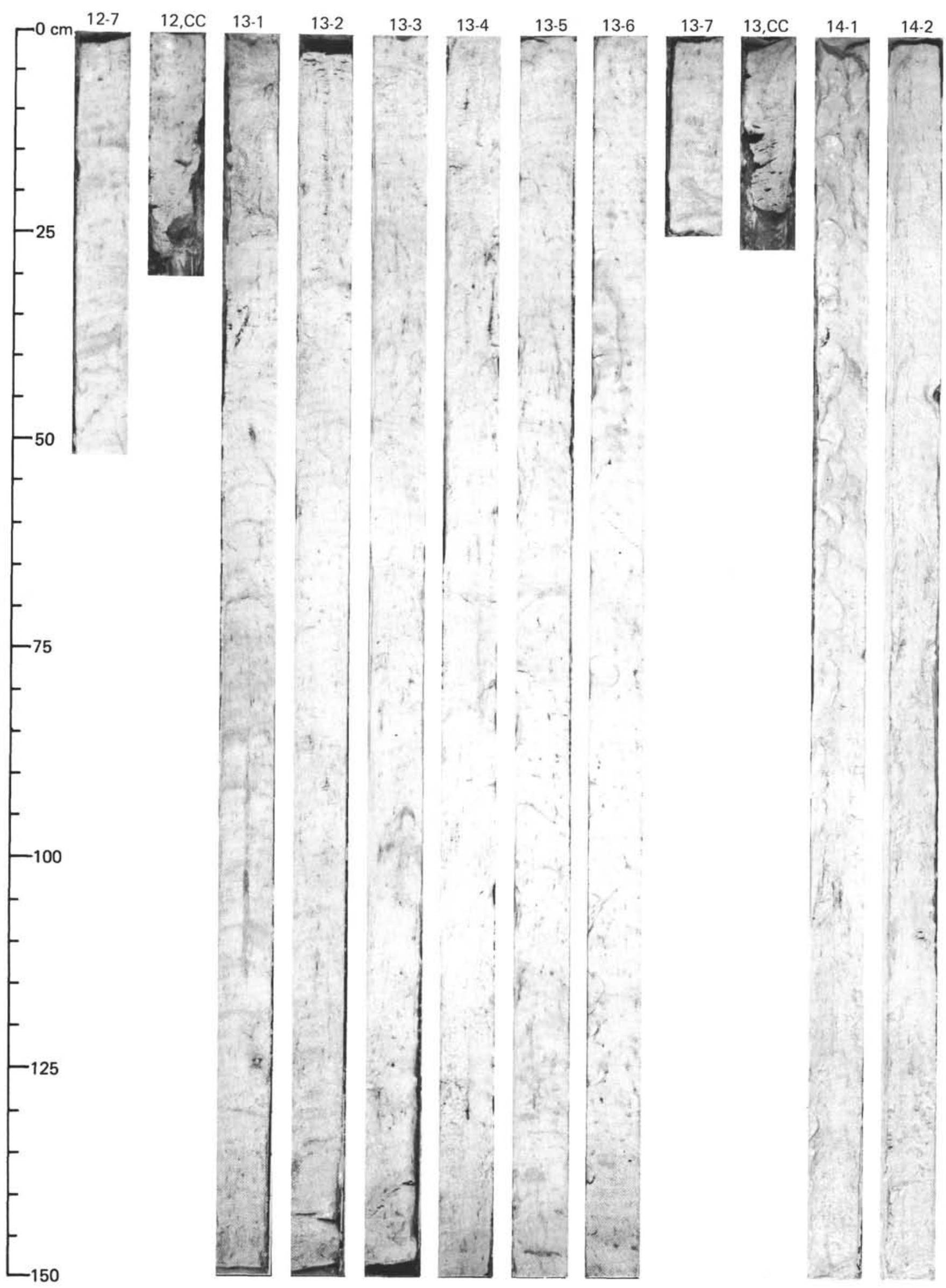




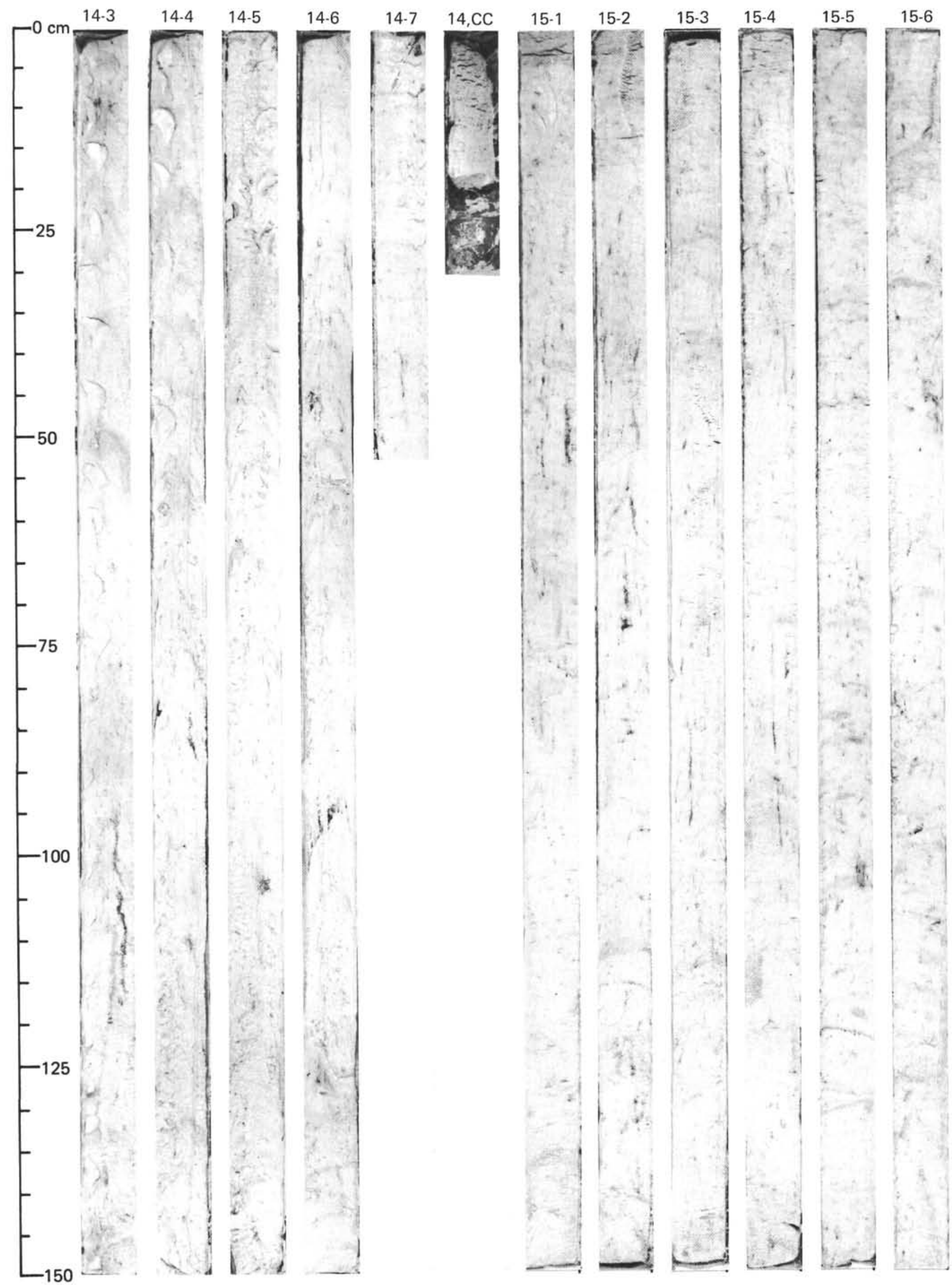




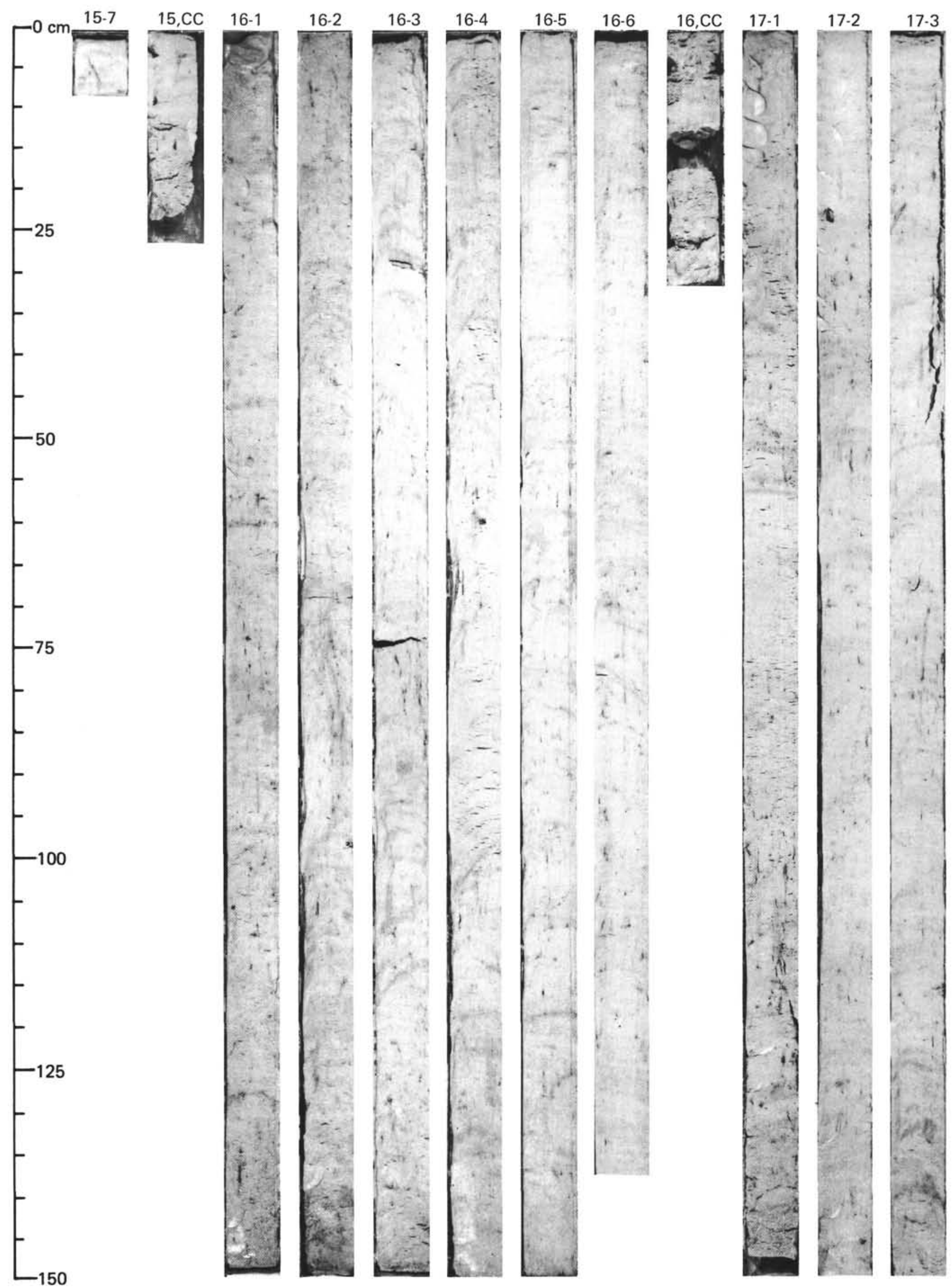


SITE 588 (HOLE 588B)

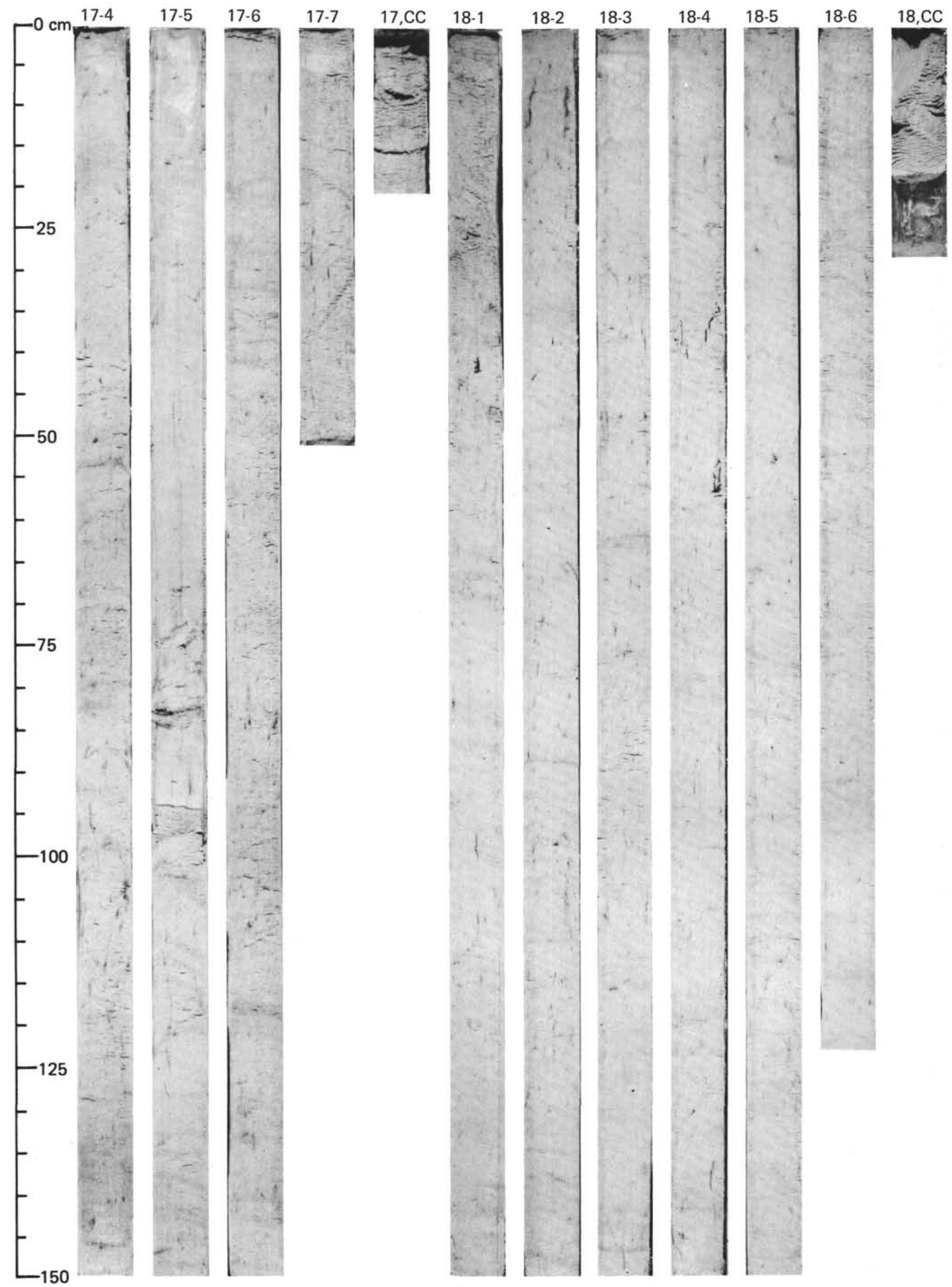




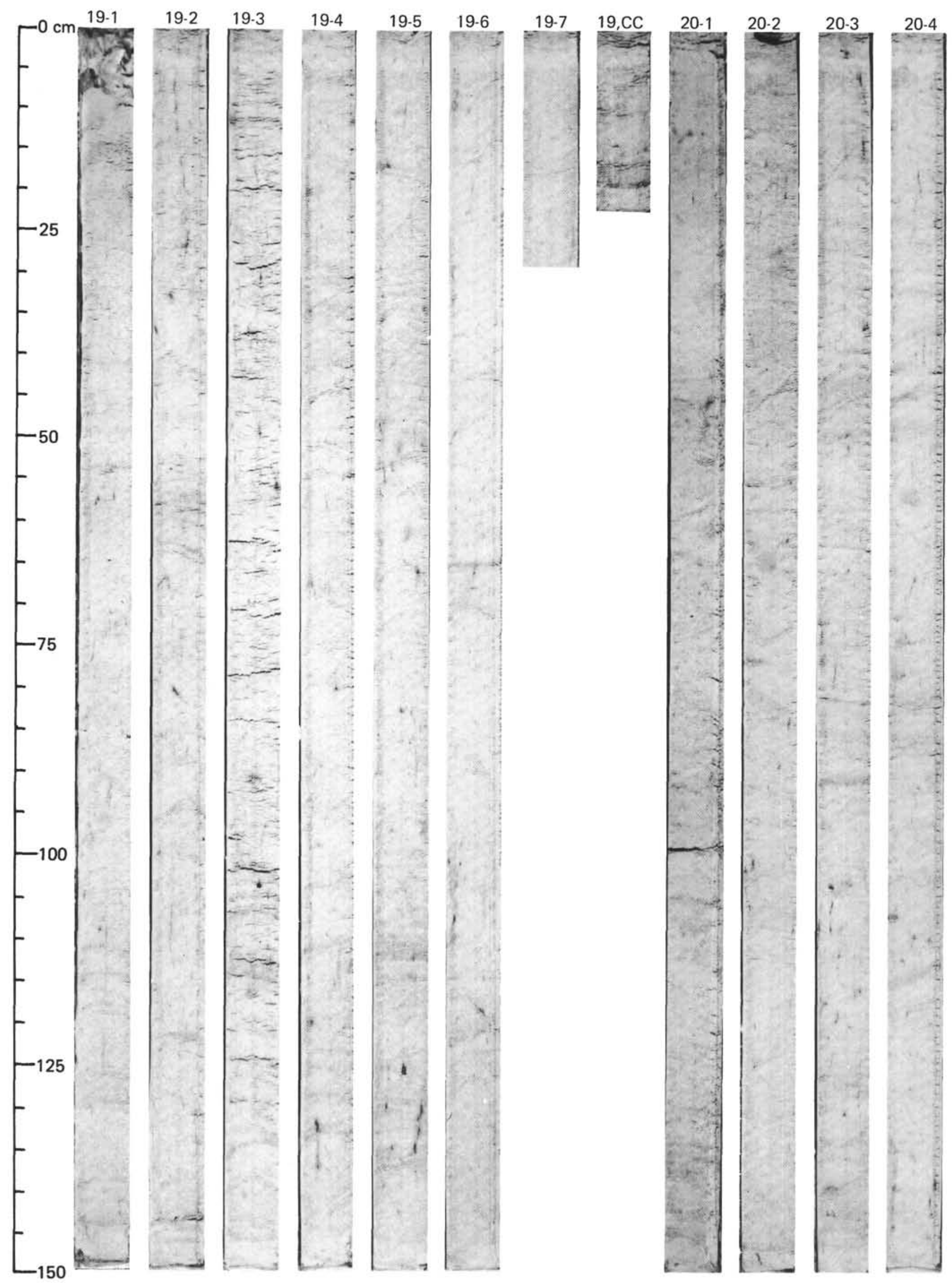


SITE 588 (HOLE 588B)

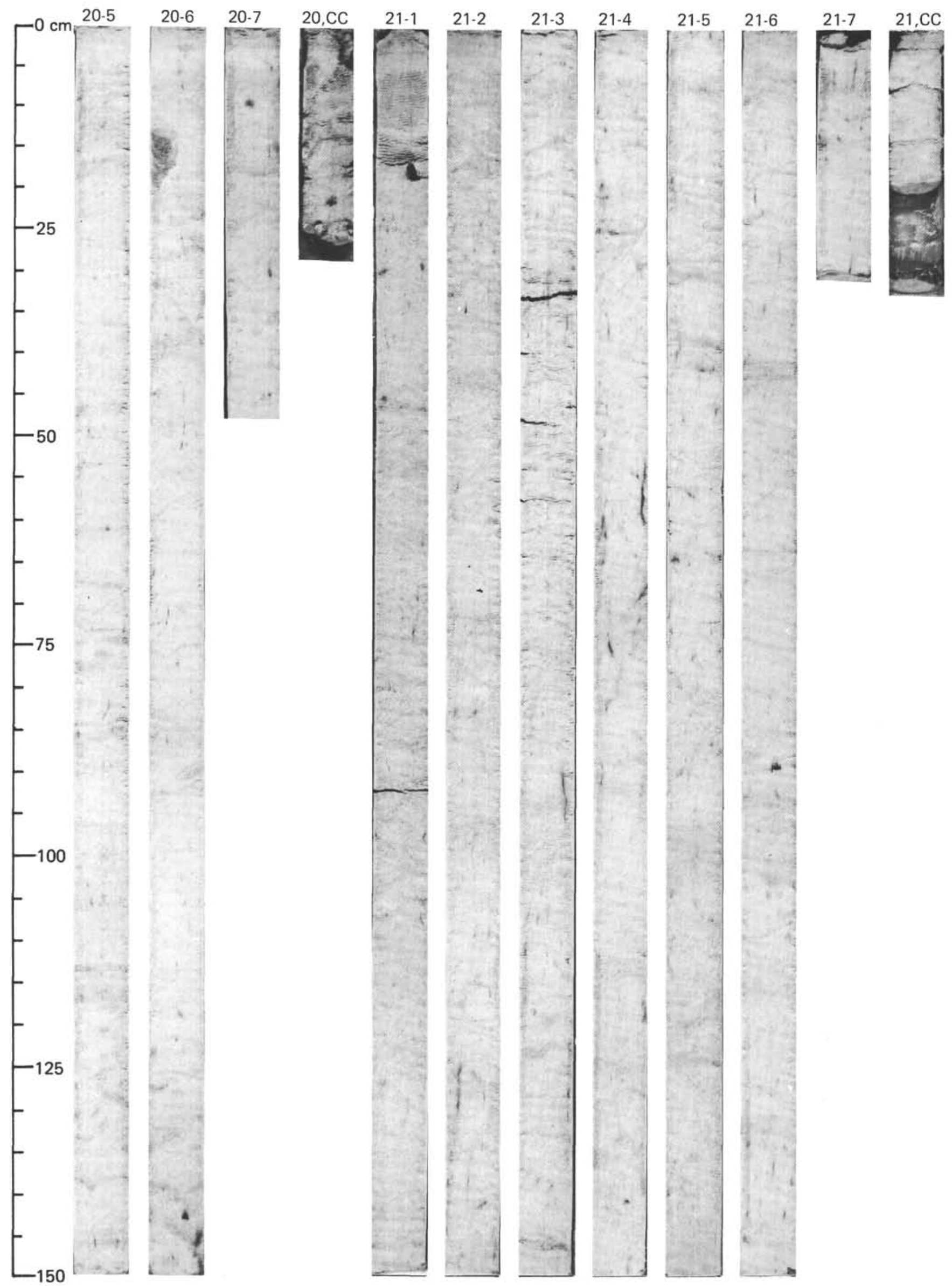


SITE 588 (HOLE 588B)

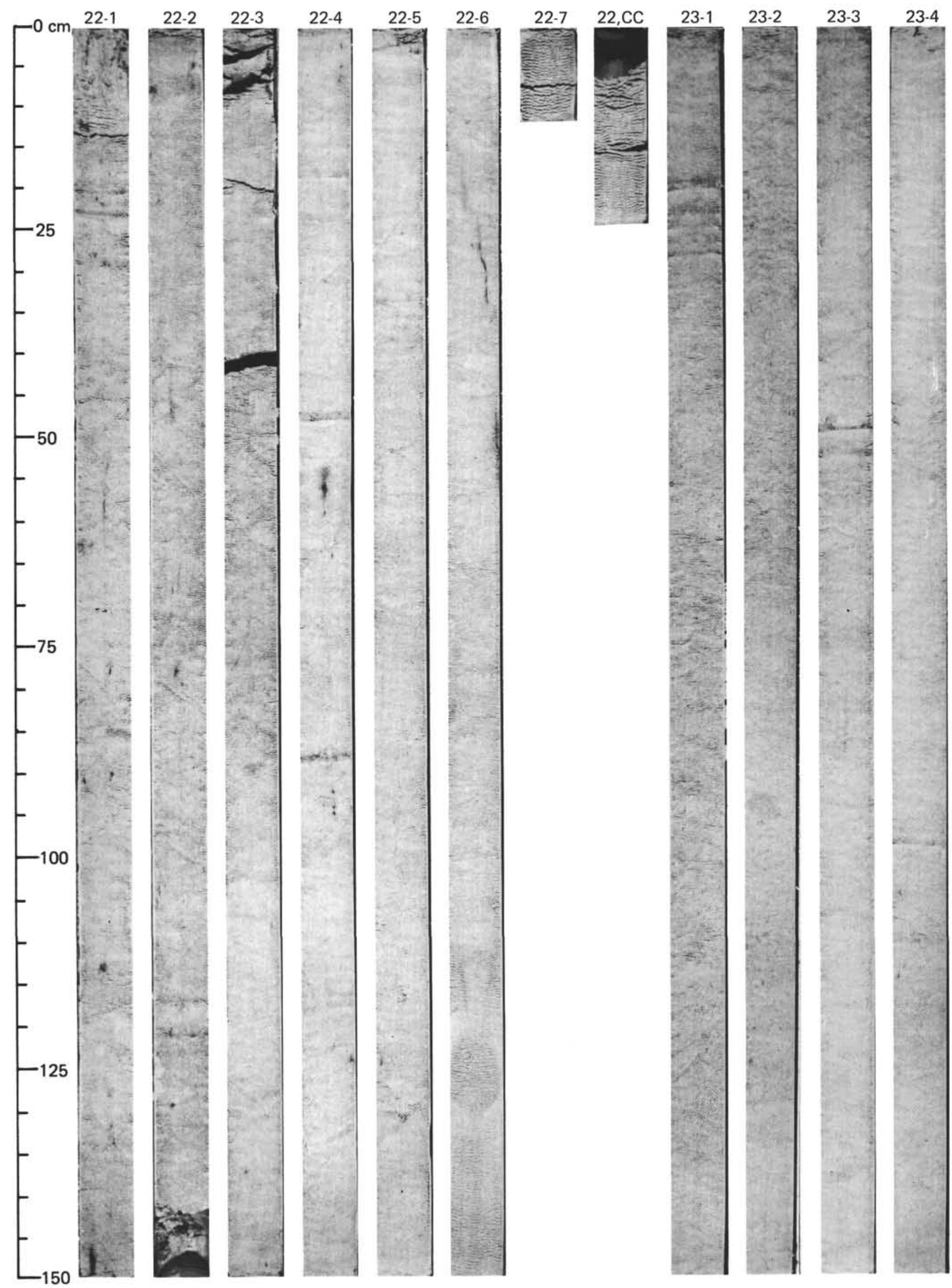


SITE 588 (HOLE 588B)

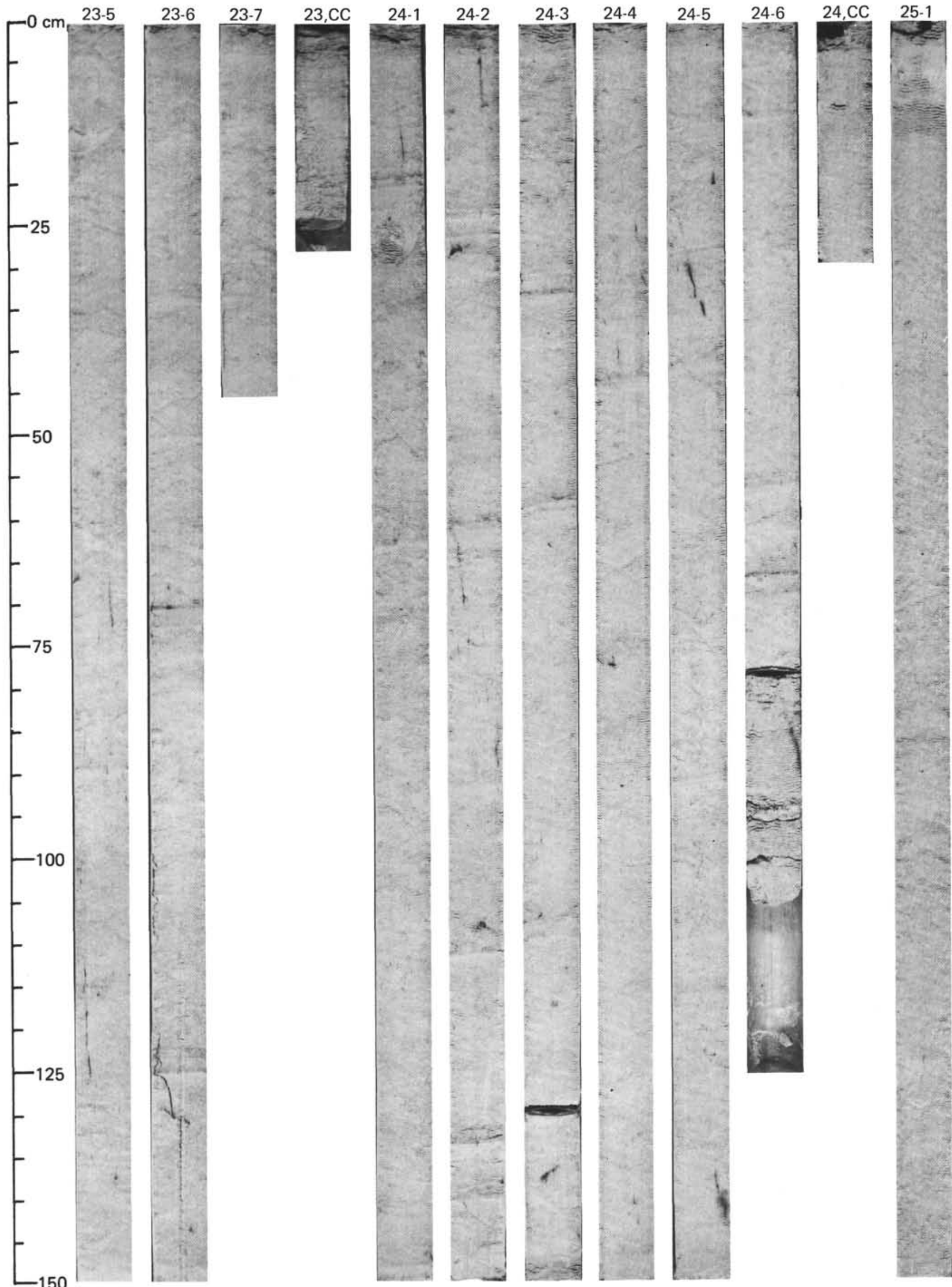


SITE 588 (HOLE 588B)

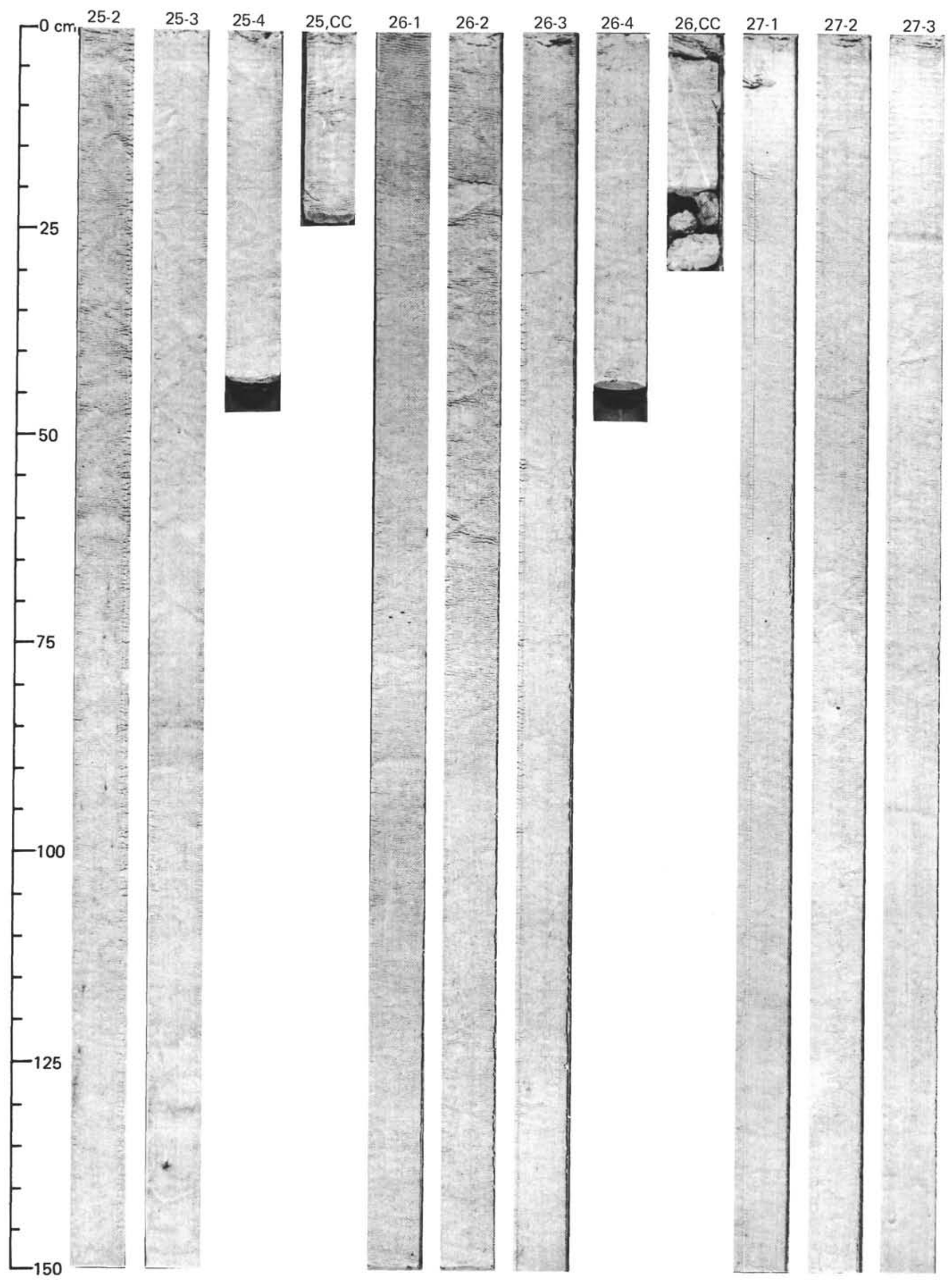




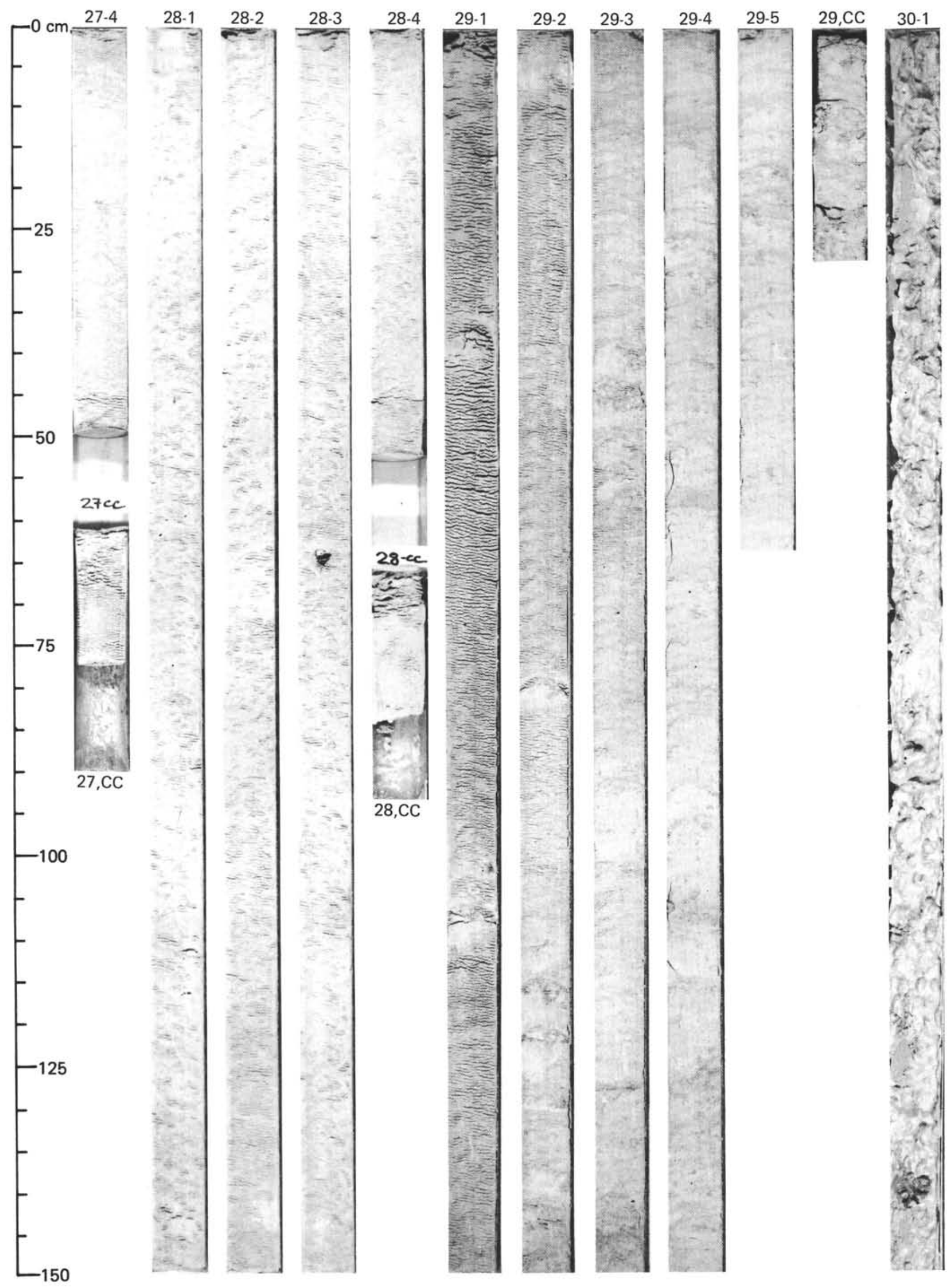



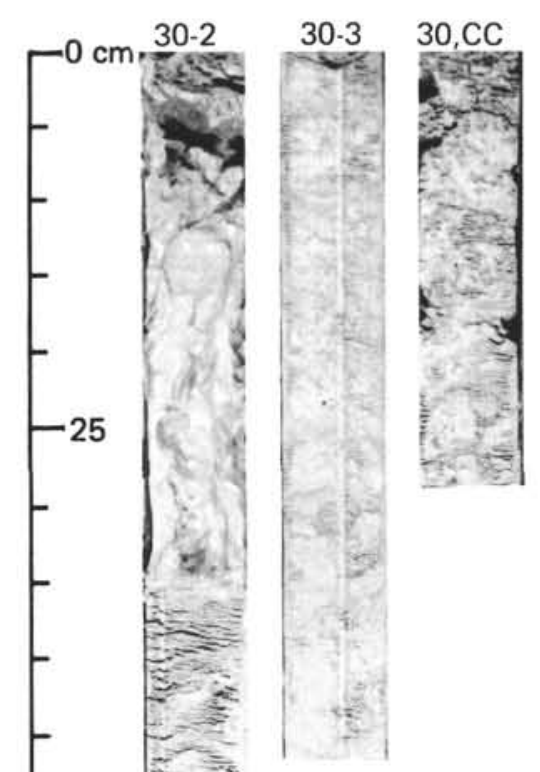
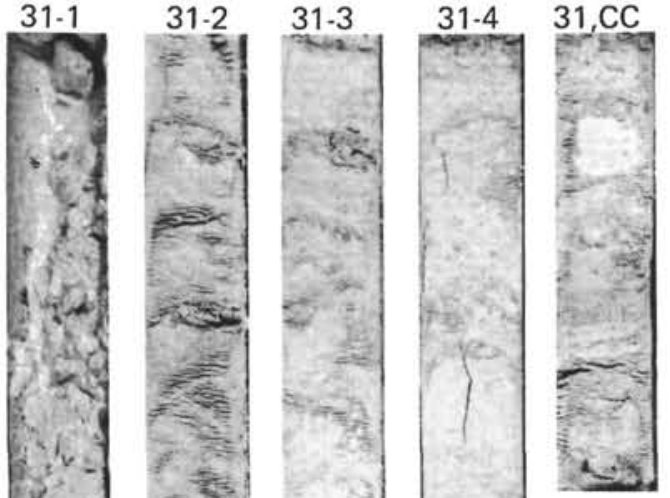

$-50$

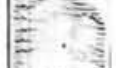

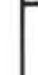
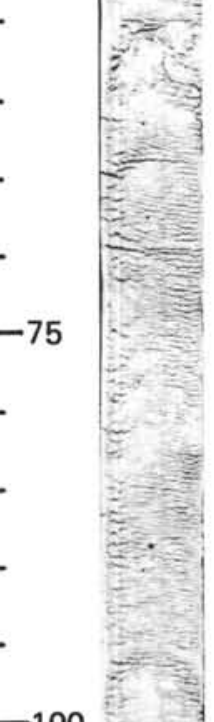

100

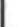
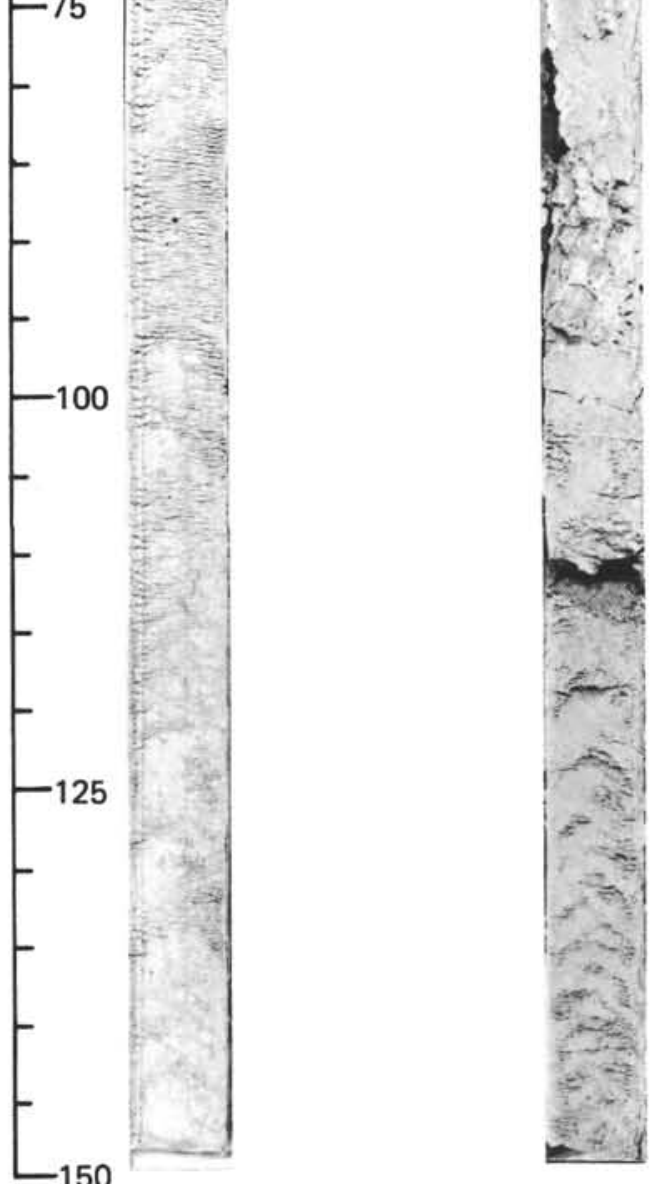

(ing)
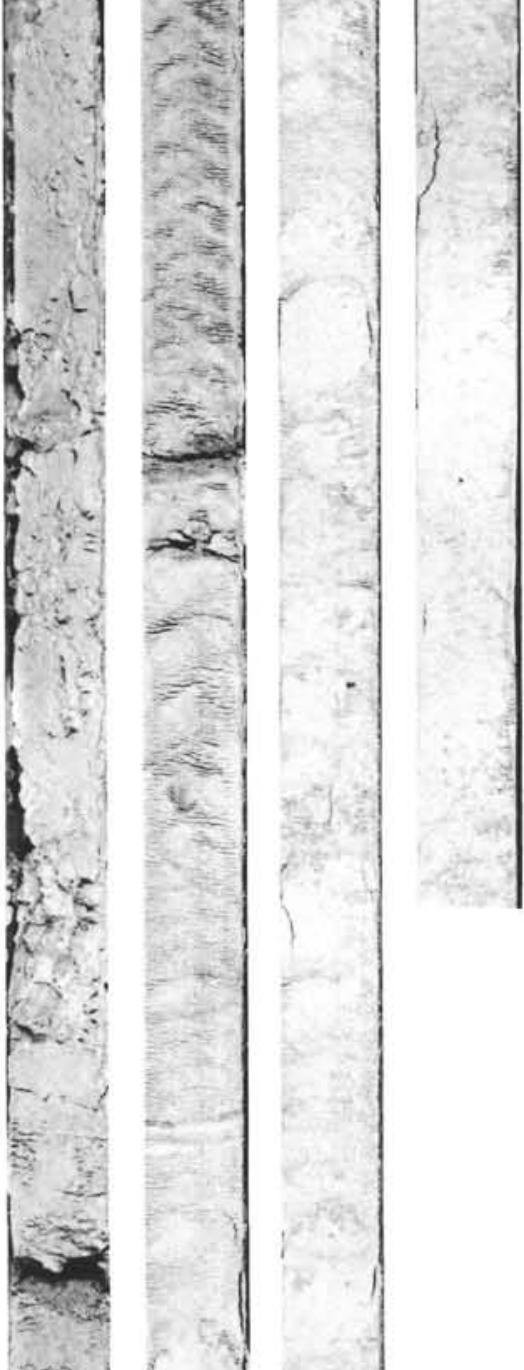

\section{.}

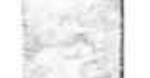

$\therefore$
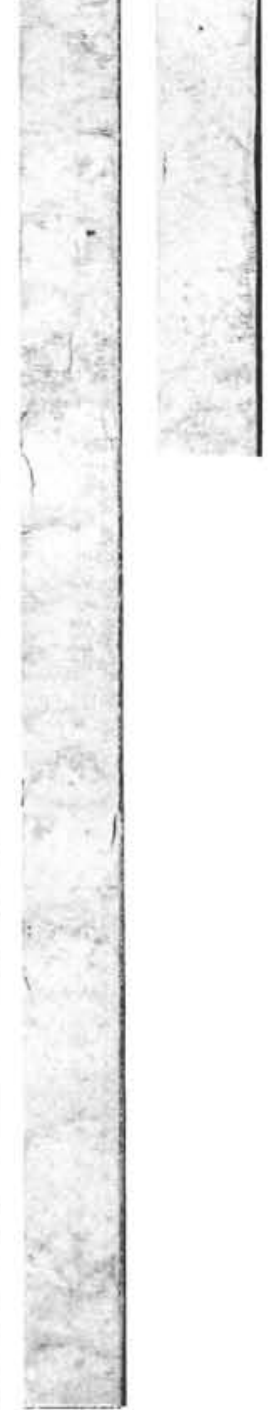
SITE 588 (HOLE 588C)

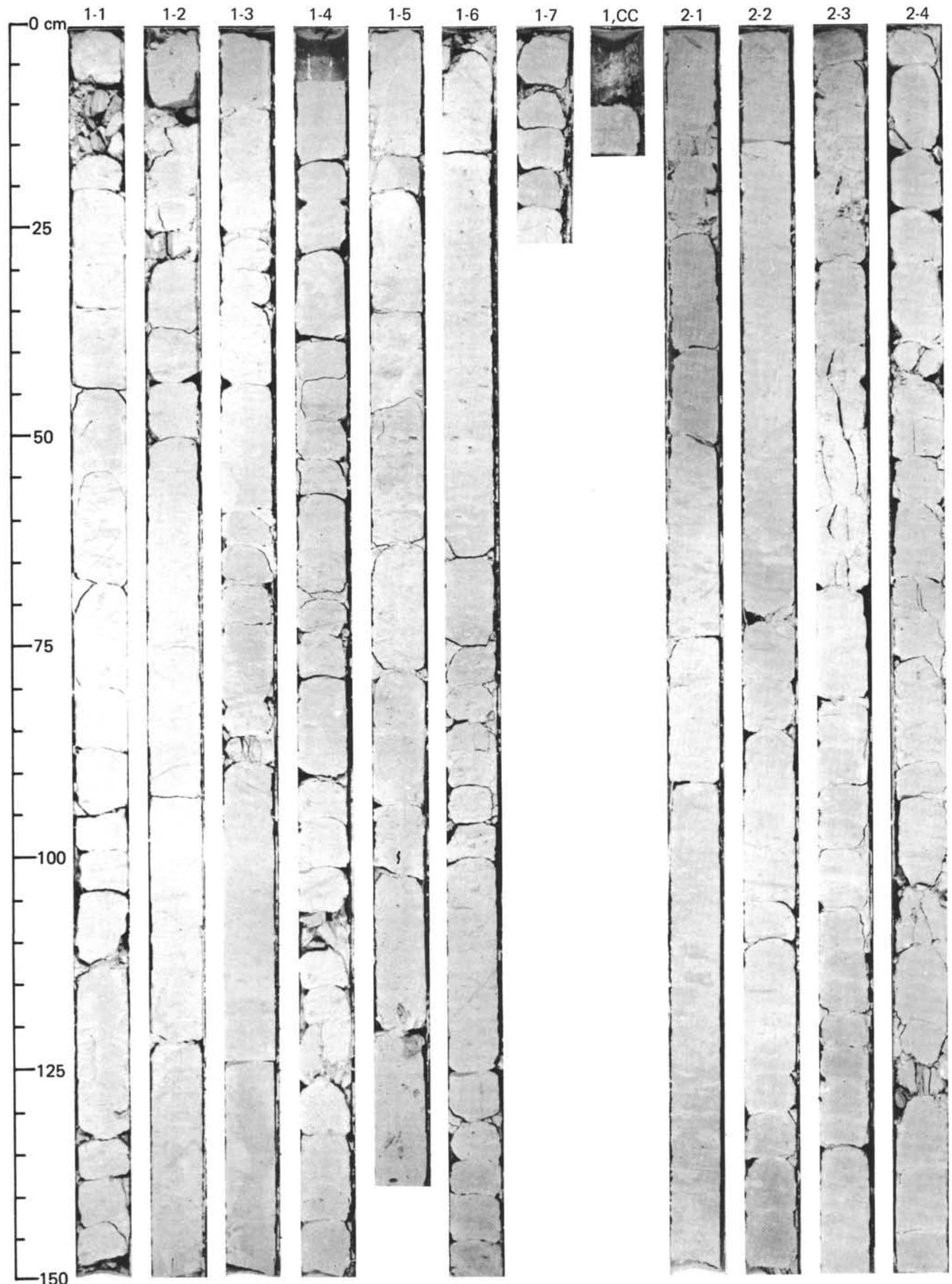


SITE 588 (HOLE 588C)

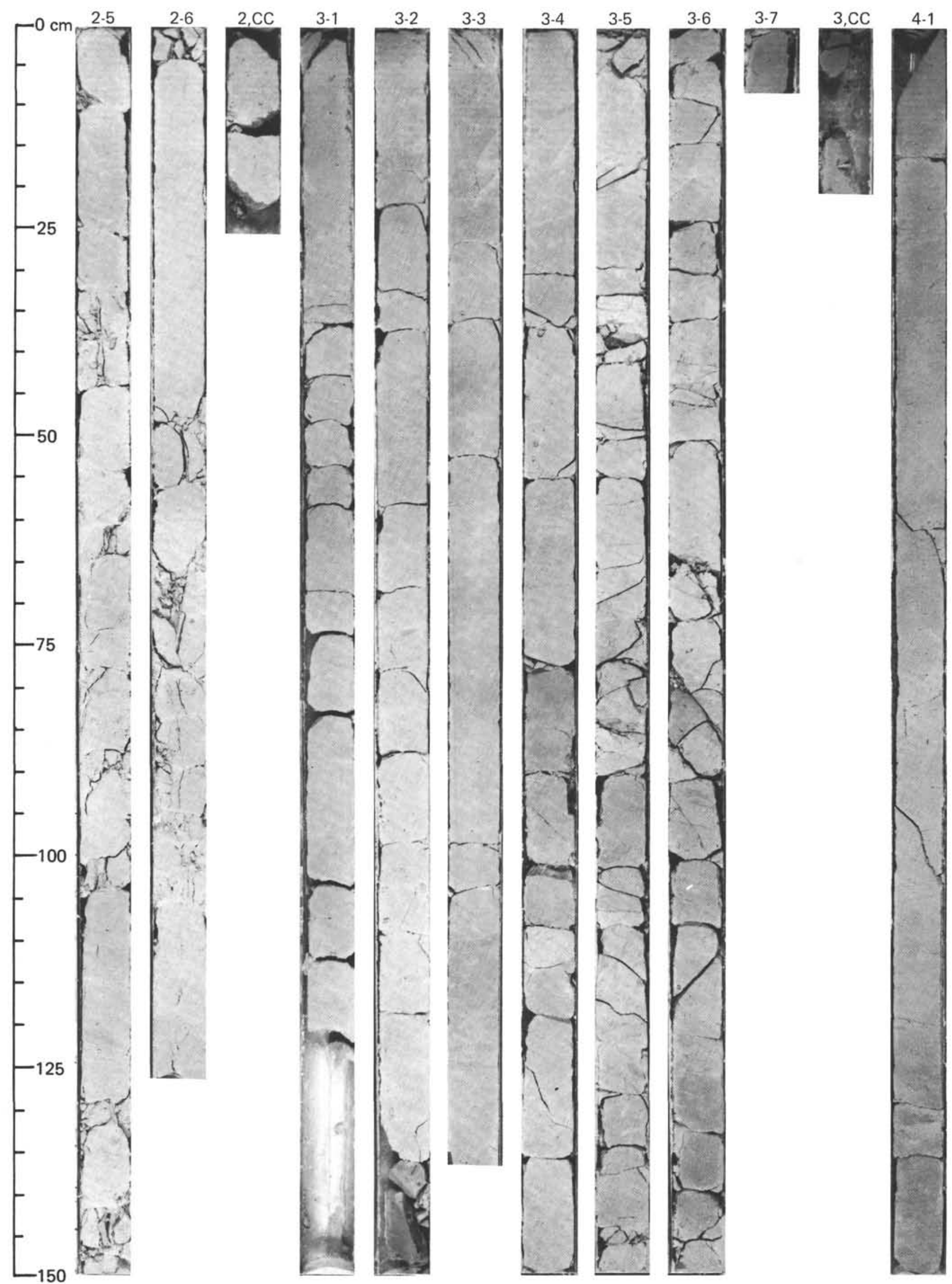




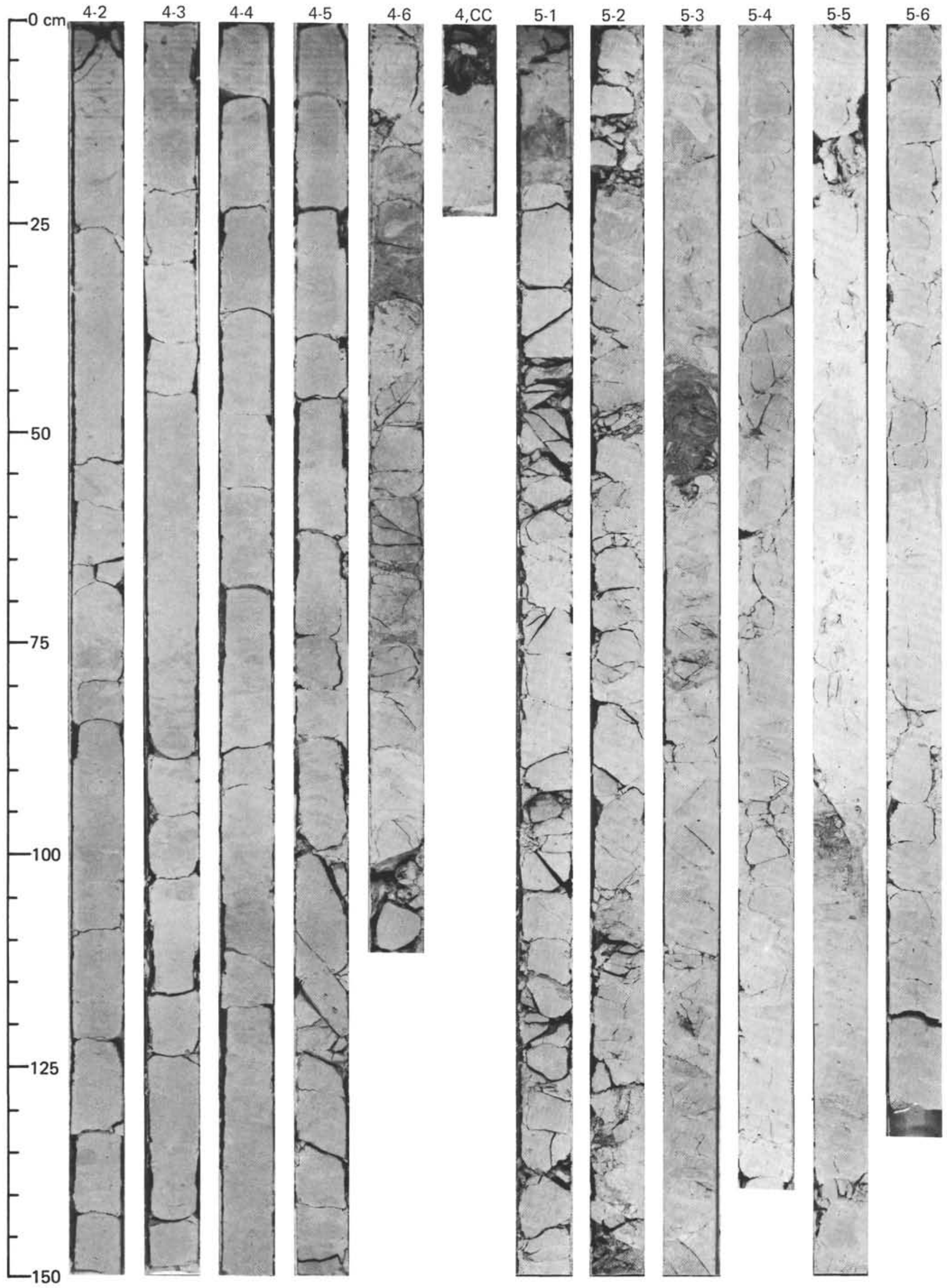




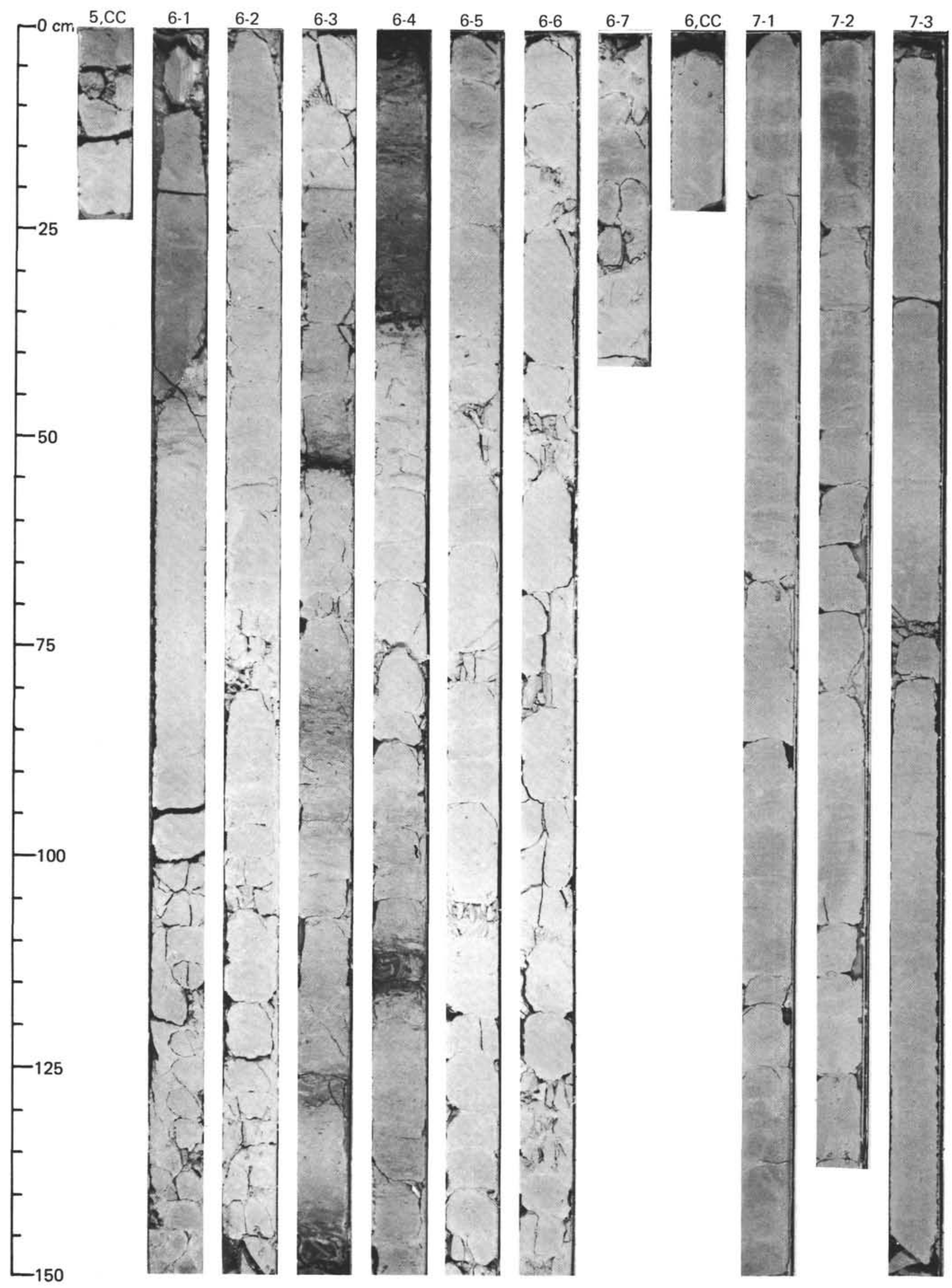


SITE 588 (HOLE 588C)

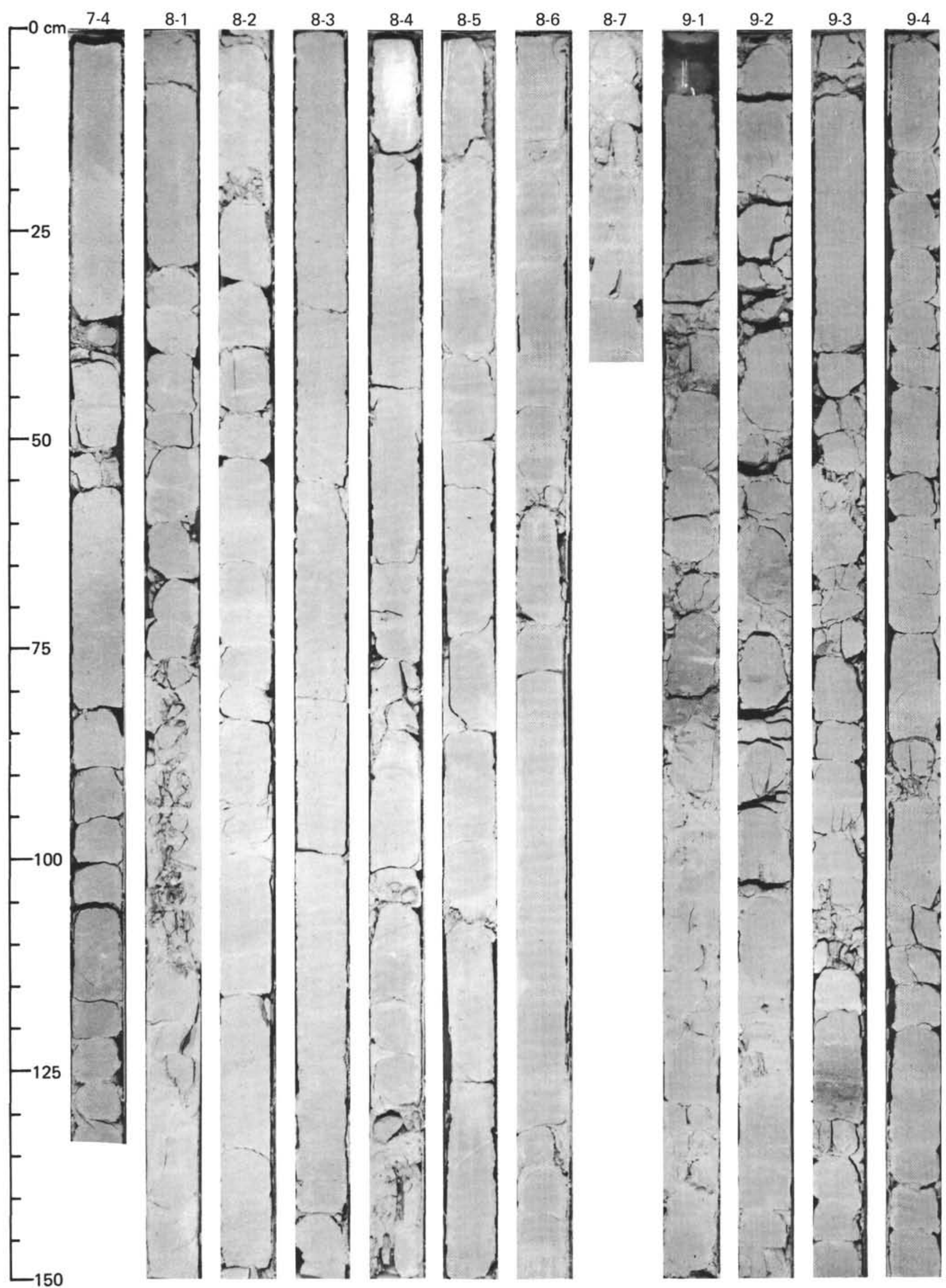




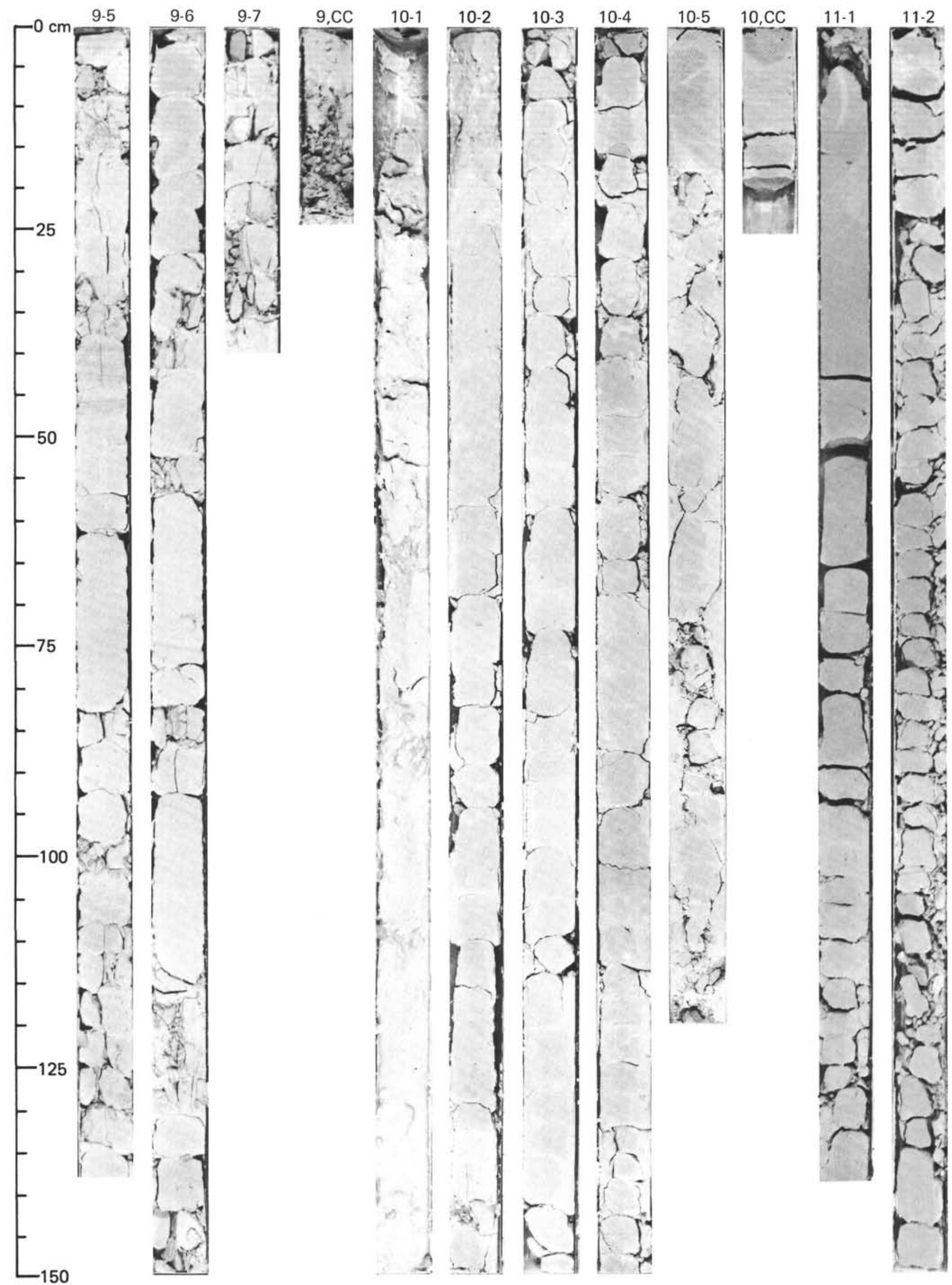


SITE 588 (HOLE 588C)

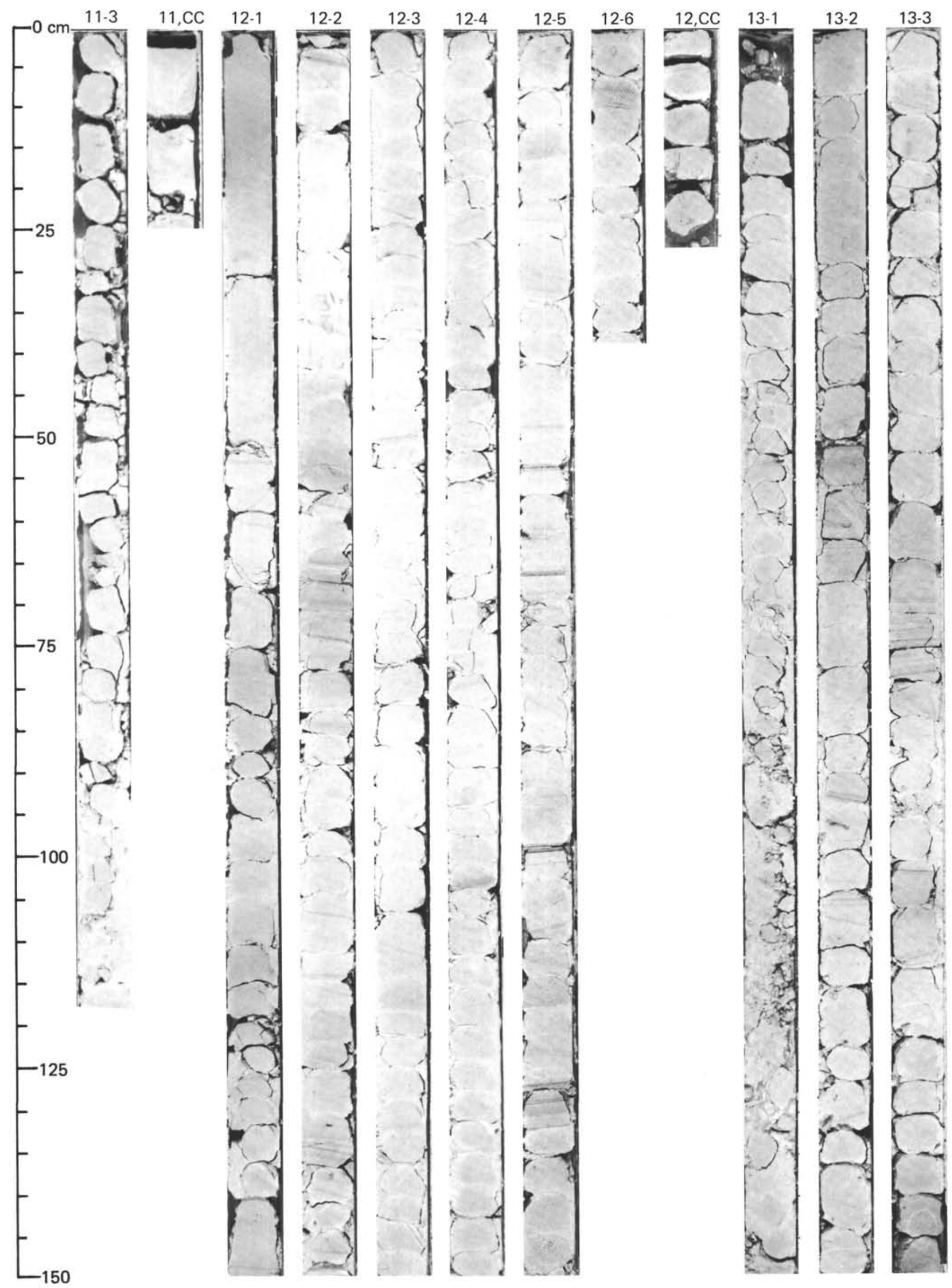


SITE 588 (HOLE 588C)

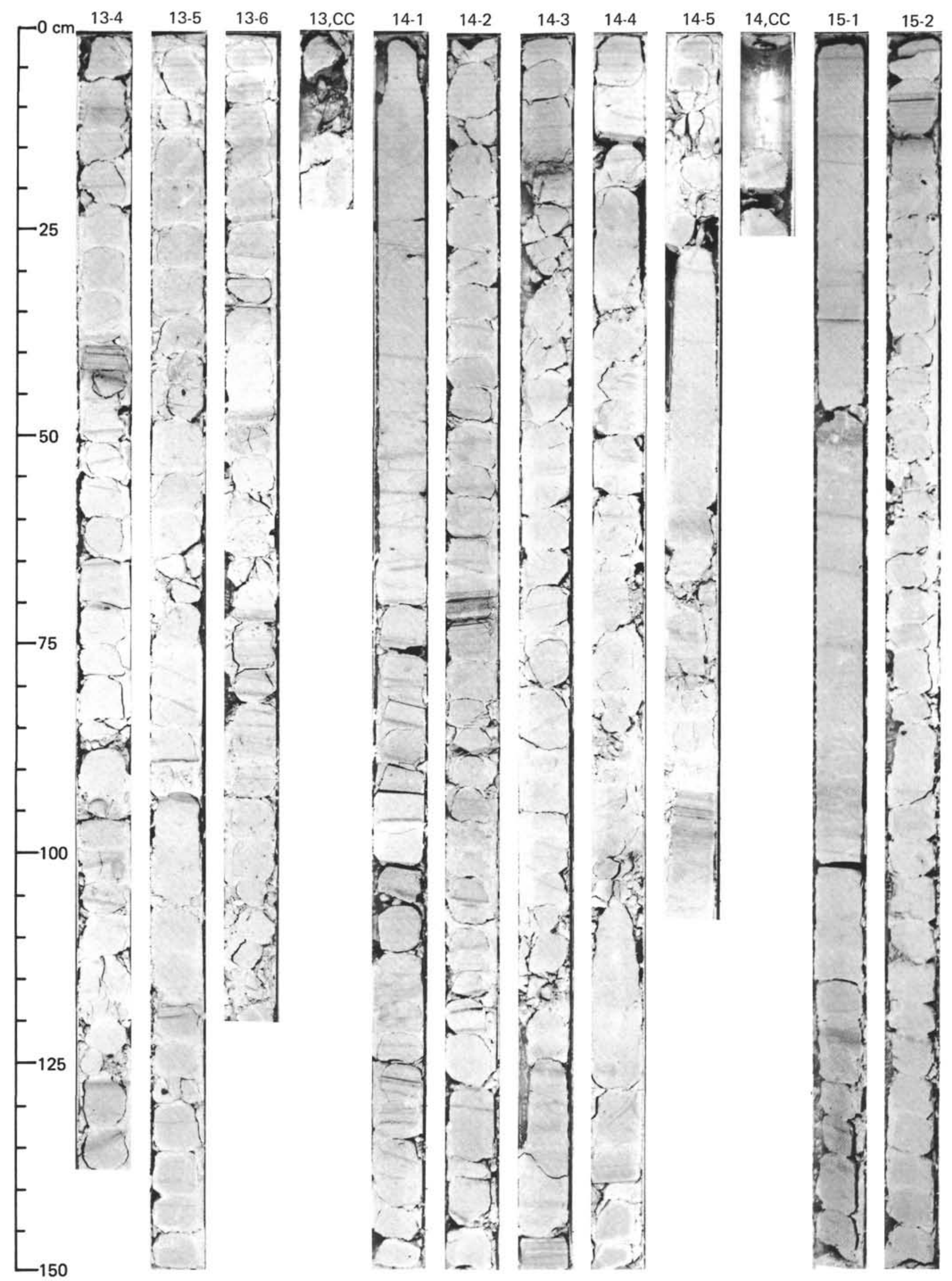




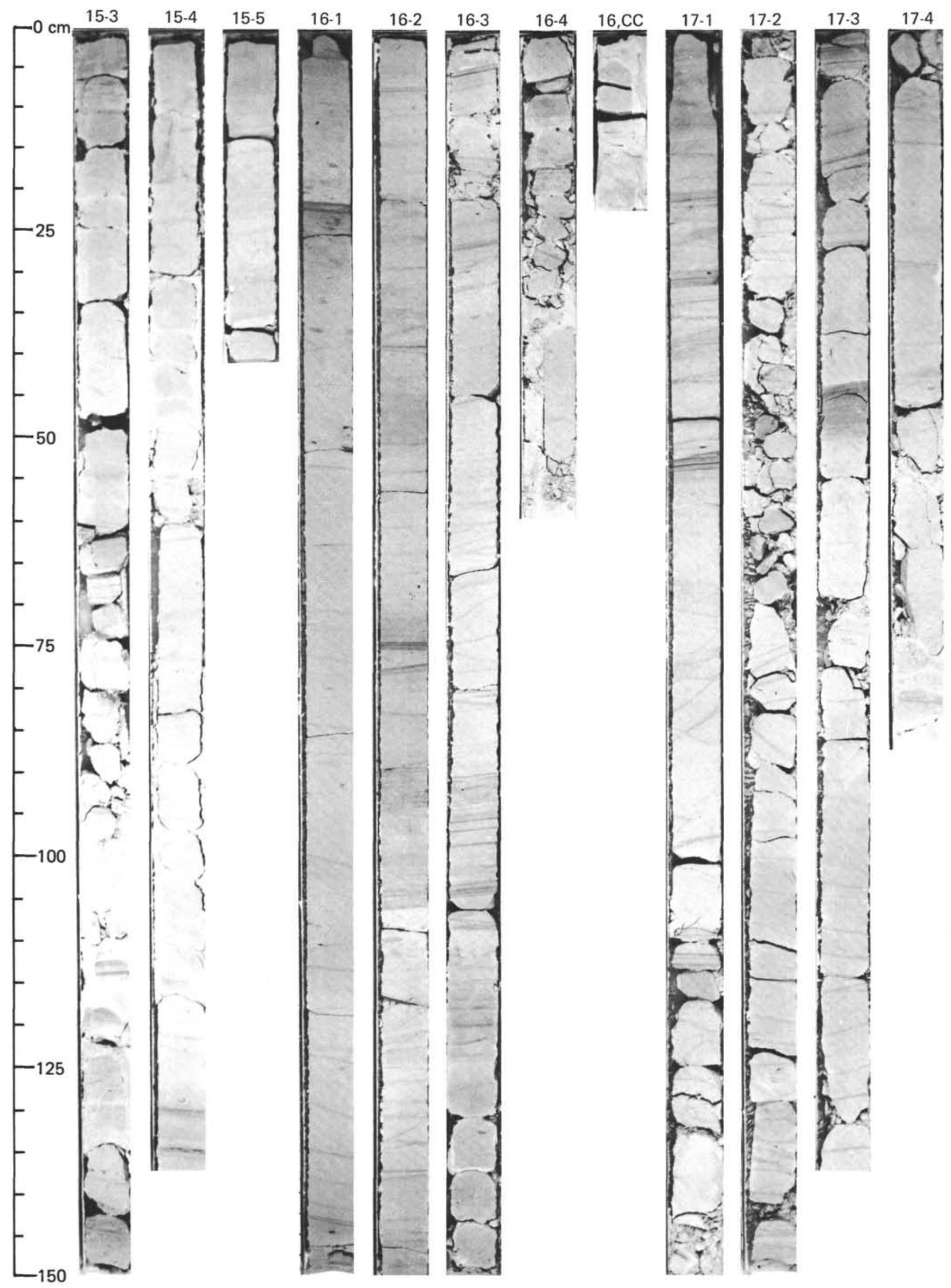


SITE 588 (HOLE 588C)

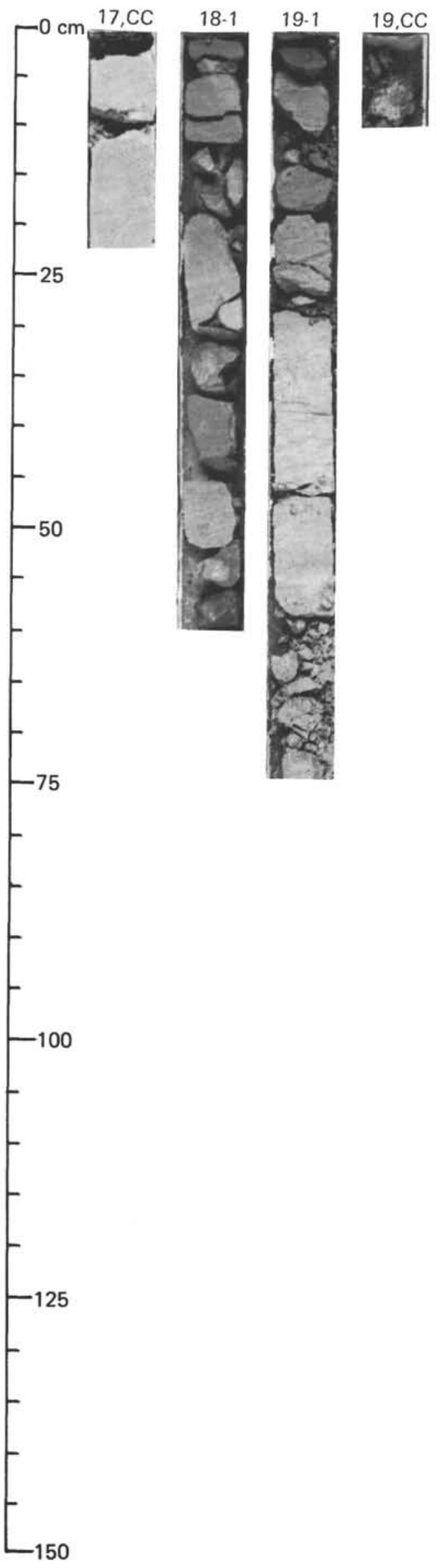

